983

REMARKS ON THE VOCABULARY OF THE ANCIENT ORATIONS IN THE MISSALE ROMANUM 


\section{Promotor:}

PROF. DR. GHR. A. E. M. MOHRMANN 


\title{
REMARKS ON THE VOGABULARY OF THE ANCIENT ORATIONS IN THE MISSALE ROMANUM
}

\author{
ACADEMISGH PROEFSGHRIFT
}

TER VERKRIJGING VAN DE GRAAD VAN DOCTOR IN DE LETTEREN AAN DE KATHOLIEKE UNIVERSITEIT TE NIJMEGEN, OP GEZAG VAN DE RECTOR MAGNIFICUS DR. H. J. LAMMERS, HOOGLERAAR IN DE FAGULTEIT DER GENEESKUNDE, VOLGENS BESLUIT VAN DE SENAAT IN HET OPENBAAR TE VERDEDIGEN OP WOENSDAG 10 JULI 1963 DES NAMIDDAGS TE 2 UUR

DOOR

MARY PIERRE ELLEBRACHT geboren te Bridgeton, Missouri, U.S.A.

DEKKER \& VAN DE VEGT N.V. NIJMEGEN - UTRECHT 
To my beloved parents

and my religious community 
CONTENTS

ABBREVIATIONS . . . . . . . . . . . . VII

BIBLIOGRAPHY ............... $\mathbf{x}$

INTRODUCTION ............... $\mathrm{xxx}$

CHAPTER I. "CHRISTIANISMS" IN THE ORATIONS . 1

A. DIRECT CHRISTIANISMS . . . . . . . . . . . . . . 1

1. Loanwords . . . . . . . . . . . . . . . . . 2

2. Latin new-forms . . . . . . . . . . . . . . 9

3. Semantics............ . . 19

B. INDIRECT CHRISTIANISMS . . . . . . . . . . . . . . 61

C. SOME REMARKS ON THE DERIVED ADJECTIVE . . . . . . 63

CHAPTER II. WORDS WHICH HAVE A TECHNICAL LITURGIGAL SENSE . . . . . . . . . 67

A. WORDS WHICH HAVE REFERENCE TO THE EUCHARIST AS SUCH 67

1. Mysterium and Sacramentum . . . . . . . . 67

2. Terms designating the gifts offered and the act of offering 75

3. Terms which express the action of God in regard to the gifts 86

B. TERMS DESIGNATING THE PERFORMANCE OF THE CULTIC ACT 91

1. Words designating the ritual action as such . . . . . 91

2. Some names given to the liturgical celebration . . . . . 107

C. PRAYER TERMS . . . . . . . . . . . . . . . . . . 114

D. TERMS WHICH HAVE REFERENCE TO THE INNER EFFICACY OF THE SACRED ACTION . . . . . . . . . . . . . . . 122

1. Terms designating divine activity . . . . . . . . . . . 122

2. Some very general terms. . . . . . . . . . 130

CHAPTER III. TERMS FROM GROUP LANGUAGES. . 135

A. PAgan roman religious terms . . . . . . . . 135 
B. LEGAL TERMS. . . . . . . . . . . . . . . . 151

C. MilitARY TERMS . . . . . . . . . . . . . . . . . 173

D. MEDICAL TERMS . . . . . . . . . . . . . . . . 178

CHAPTER IV. BIBLICAL ELEMENTS . . . . . . . . . 191

A. VARIOUS SCRIPTURAL REFERENCES . . . . . . . . . . 191

B. DIVERSE TERMS WITH BIBLICAL BACKGROUND . . . . . . 194

CONCLUDING REMARKS . . . . . . . . 198

TABLE LISTING ORATIONS STUDIED . . . . . . . . 204

INDEX OF GREEK WORDS. . . . . . . . . . . . . . 213

INDEX OF LATIN WORDS . . . . . . . . . . . 215 


\section{ABBREVIATIONS}

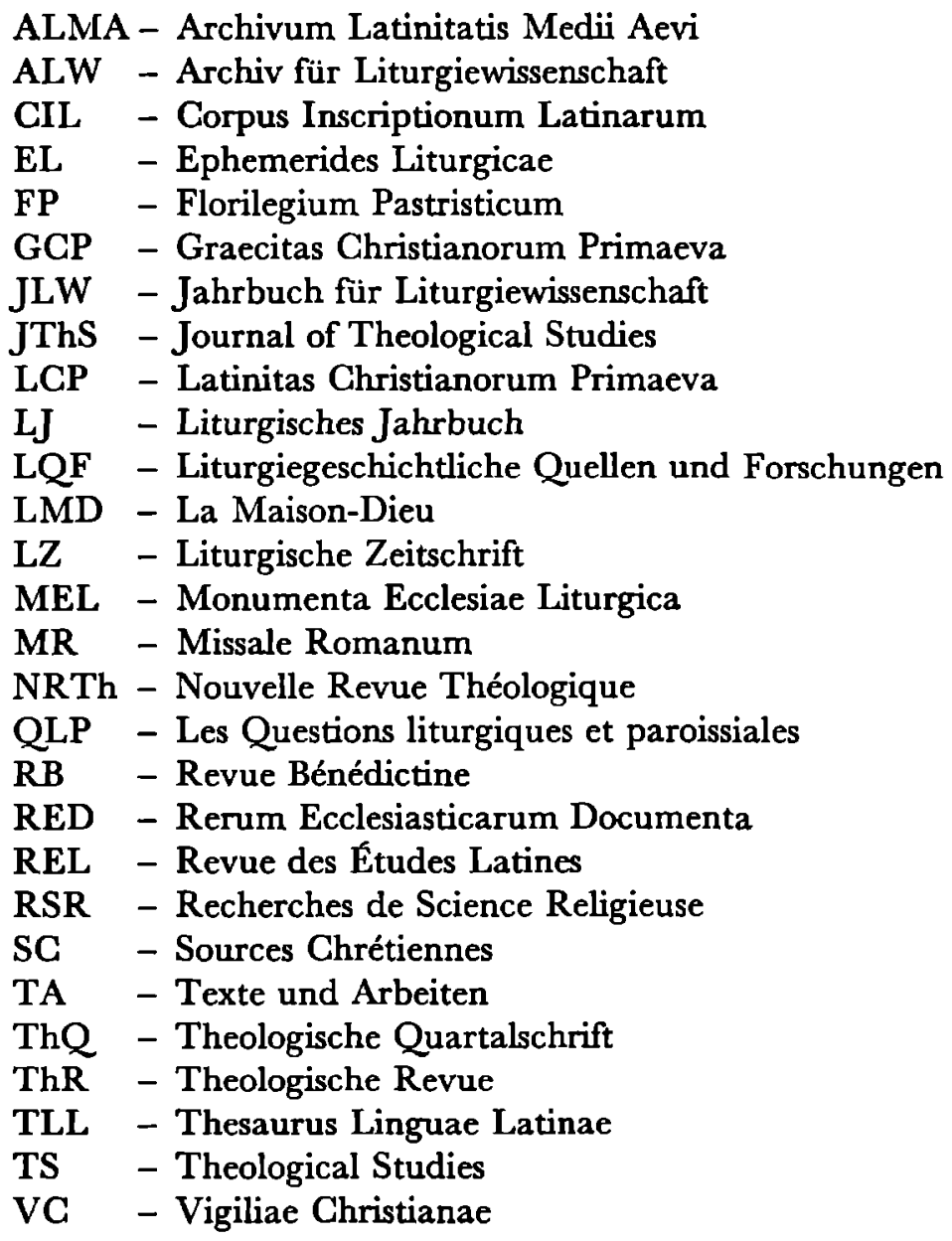





\section{BIBLIOGRAPHY}

Aalio, Pentri, Untersuchungen über das lateinische Gerundium und Gerundivum, Annales Acad. Scient. Fennicae LXII, 3, Helsinki 1949.

Anderson, W. J., Fragments of an Eighth-Century Gallican Sacramentary, JThS 29, 1927-28, p. $344 \mathrm{ff}$.

ANDRIEU, Michel, Quelques remarques sur le classement des Sacramentaires, JLW 11, 1931, p. $46 \mathrm{ff}$.

-, Les Ordines Romani du haut moyen âge, I-V, Spicilegium sacrum Lovaniense 11 , 23, 24, 28, 29, Louvain 1931-1961.

Appel, G., De Romanorum precationibus, Religionsgesch. Vers. u. Vorarb. 7, 2, Giessen 1909.

Astworth, H., The Liturgical Prayers of St. Gregory the Great, Traditio 15, 1959, p. $107 \mathrm{ff}$.

Audet, Jean-Paul, La didachd. Instructions des Apôtres, Etudes Bibliques, Paris 1958.

BaLLY, CH., Linguistique générale et linguistique franfaisę ${ }^{2}$, Berne 1944.

Bannister, H. M., Liturgical Fragments, JThS 9, 1908, p. $405 \mathrm{ff}$.

-, Missale Gothicum, Henry Bradshaw Society 52, London 1915.

BARDY, G., Tractare - tractatus, RSR 33, 1946, p. $211 \mathrm{ff}$.

—, La question des langues dans l'Église ancienne, I, Paris 1948.

_, Saint Augustin et les médecins, Année théologique augustinienne, 13, 1953, p. $327 \mathrm{ff}$.

Bartelink, G. J. M., Lexicologisch-semantische studie over de taal van de Apostolische Vaders. Bijdrage tot de studie van de groeptaal der Griekse Christenen, Utrecht 1952.

Bastuaengen, A. A. R., Observations sur le vocabulaire liturgique dans l'Itinéraire d'Égérie, LCP 17, Nijmegen 1962.

Battffol, P., Legons sur la Messe? ${ }^{7}$, Paris 1927.

BAUmstaRk, A., Die geschichtliche Stellung der Oration "Gratiam tuam, quaesumus, Domine", JLW 3, 1923, p. $108 \mathrm{ff}$.

-, Vom geschichtlichen Werden der Liturgie, Ecclesia orans 10, Freiburg 1923.

-, Das Problem des römischen Messkanons, EL 53, 1939, p. $220 \mathrm{ff}$.

-, Antik-römischer Gebetsstil im Messkanon, Miscellanea liturgica in honorem L. Cuniberti Mohlberg, I, Rome 1948, p. $301 \mathrm{ff}$.

Baumstark, A. - Botre, B., Comparative Liturgy, translated from the French (Liturgie compares, Paris 1953) by F. L. Cross, Westminster, Md. 1957.

Baus, KarL, Der Kranz in Antike und Christentum. Eine religionsgeschichtliche Untersuchung mit besonderer Berücksichtigung Tertullians, Bonn 1940.

Becker, O., Das Bild des Weges und verwandte Vorstellungen im frühgriechischen Denken, Hermes, Einzelschriften 4, Berlin 1937. 
Bernert, E., De vi atque usu vocabuli officii, Breslau 1930.

BERRY, G. R., The Glory of Jahweh and the Temple, Journal of Biblical Literature 56, 1937, p. $115 \mathrm{ff}$.

La Sainte Bible traduite en français sous la direction de l'École Biblique de Jérusalem, Paris 1956.

Bishop, EdMund, Liturgica Historica, Oxford 1918.

-, La réforme liturgique de Charlemagne, EL 45, 1931, p. 203 ff.

Blaise, Albert, Dictionnaire latin-frangais des auteurs chrétiens, Strasbourg 1954.

Bonnet, Max, Le latin de Gregoire de Tours, Paris 1890.

Botre, B., La gloire du Christ dans l'Evangile de Saint Jean, QLP 12, 1927, p. 65 ff.

-, Le Canon de la Messe Romaine. Edition critique, introduction el notes, Textes et études liturgiques 2, Louvain 1935.

-, Confessor, ALMA 16, 1942, p. $137 \mathrm{ff}$.

-, Paschalibus initiata mysteriis, EL 61, 1947, p. 77 ff.

Botte, B.-Mohrmanv, Chr., L'ordinaire de la Messe. Texte crilique, traduction et études, Études liturgiques 2, Paris-Louvain 1953.

Bouman, C. A., Variants in the Introduction to the Eucharistic Prayer, VC 4, 1950, p. $94 \mathrm{ff}$.

-, Sacring and Crowning. The Development of the Latin Ritual for the Anointing of Kings and the Coronation of an Emperor before the Eleventh Century, Groningen 1957.

-, Communis oratio. Problemen betreffende de uroegste geschiedenis van het christelijke smeekgebed, Utrecht-Antwerpen 1959.

Bouyer, Lours, La vie de la liturgie, Lex Orandi 20, Paris 1956.

BRAUN, J., Der christliche Altar in seiner geschichtlichen Entwicklung, I-II, Munchen 1924.

Braun, RenE, "Deus Christianorum". Recherches sur le vocabulaire doctrinal de Tertullien, Publications de la Faculté des Lettres et Sciences Humaines d'Alger 41, Paris 1962.

Brnnktrune, J., Zur Entstehung der morgenländischen Epiklese, Zeitschrift für kath. Theologie 42, 1918, p. 301 ff.; 482 ff.

Brou, Lous, L'oraison 'Deus, qui conteris bella' de la messe votive 'Tempore belli', EL 60, 1946, p. $293 \mathrm{ff}$.

- The Psalter Collects, from V-VIth Century Sources. Edited from the Papers of the Late Dom Andre Wilmart, Henry Bradshaw Society 83, London 1949.

-, Les oraisons des dimanches apres la Pentecóte. Commentaire liturgique, Paroisse et Liturgie 38, Bruges 1959.

—, Les oraisons dominicales. De l'Avent à la Trinitל, Paroisse et Liturgie 50, Bruges 1960.

Bruylants, Placme, Concordance verbale du Sacramentaire leonien, ALMA 1B, 1945, p. 51 ff.; 19, 1948, p. $39 \mathrm{ff}$.

-, Les oraisons du Missel Romain, I-II, Etudes liturgiques 1, Louvain 1952.

Cabrol, F. - Leclere, H. - Marrou, H. - I., Dictionnaire d'archéologie chrétienne et de liturgie, Paris $1907 \mathrm{fr}$.

Callewaert, C., Saint Léon le Grand et les lextes du Llonien, Sacris Erudiri 1, p. 35 ff. (later published apart: Steenbrugge-'s-Gravenhage 1948).

Gamelot, Th., Credere Deo, credere Deum, credere in Deum, Les sciences philos. et thél. $1,1941-42$, p. $149 \mathrm{ff}$.

CAPElie, B., Les collectes des dimanches du temps pascal, QLP 14, 1929, p. $76 \mathrm{ff}$.

-, La collecte du troisieme dimanche apres Pâques, RB 41, 1929, p. $171 \mathrm{fr}$.

-, Collecta, RB 42, 1930, p. $197 \mathrm{ff}$.

-, La main de s. Grégoire dans le Sacramentaire grégorien, RB 49, 1937, p. $13 \mathrm{ff}$.

-, La postcommunion de la seconde messe de Noell, QLP 22, 1937, p. $298 \mathrm{ff}$. 
-, Messes du pape s. Gelase dans le Sactamentaire leonien, RB 56, 1945, p. $12 \mathrm{ff}$.

Carton, Ign., Noles sur l'emploi du mot "observantia" dans les homelies de St. Leon, VC 8, 1954, p. $104 \mathrm{ff}$.

Casel, Odo, Oblatio rationabilis, Tübinger theol. Quartalschrift 99, 1917, p. $429 \mathrm{ff}$.

-, Actio in liturgischer Verwendung, JLW 1, 1921, p. $32 \mathrm{ff}$.

-, Mysterium und Martyrium in den römischen Sacramentarien, JLW 2, 1922, p. 21 ff.

-, Zur Idee der liturgischen Festfeier, JLW 3, 1923, p. 93 ff.

-, Die Aoyıkǹ $\theta v \sigma i a$ der antiken Mystik in christlich-liturgischer Umdeutung, JLW 4, 1924, p. $37 \mathrm{ff}$.

-, Das Mysteriengedächtnis der Messliturgie im Lichte der Tradition, JLW 6, 1926, p. $113 \mathrm{ff}$.

-, Zum Worte Sacramentum, JLW B, 1929, p. 225 ff.

-, Ein orientalisches Kultwort in abendländischer Umschmelzung, JLW 11, 1931, p. 1 ff.

-, Die "Neuheit" in den Weihnachtsorationen, LZ 4, 1931, p. $83 \mathrm{ff}$.

-, Beiträge zu römischen Orationen. Die Sekret vom 9. Sonntag nach Pfingsten im römischen Messbuch, JLW 11, 1931, p. 35 ff.

—, La "nova nativitas" dans les oraisons de la Noël, QLP 17, 1932, p. 285 fr.

-, Aeltoveyla-munus, Oriens Christianus 3, 7, 1932, p. 289 ff.

-, Art und Sinn der ältesten christlichen Osterfeier, JLW 14, 1934, p. $1 \mathrm{ff}$.

-, Le mystere du culte dans le Christianisme, Lex Orandi 6, Paris 1946.

-, Zur Kultsprache des hl. Paulus, ALW 1, 1950, p. $1 \mathrm{ff}$.

Chavasse, A., Le Sactamentaire gellasien, Vatic. Regin. 316. Sactamentaire presbythal en usage dans les Titres romains au VIIe s., Bibl. de thél. IV, 1, Paris-Tournai-New York-Rome 1958.

Clark, Alan, The Function of the Offerlory Rite in the Mass. A Study in History, EL 64, 1950 , p. $309 \mathrm{ff}$.

Cochez, J., La periode métrique dans les priètes de la liturgie, QLP 6, 1921, p. $117 \mathrm{ff}$.

-, La structure thythmique des oraisons, Louvain 1928.

Congar, Y., Le mystère du temple. L'économie de la présence de Dieu à sa créature de la Gendse à l'Apocalypse, Lectio divina 22, Paris 1958.

-, Les voies du Dieu vivant. Théologie et vie spirituelle, Paris 1962.

Cortiss, J. M., Séndque et la médecine stoicienne, REL 36, 1958, p. $45 \mathrm{ff}$.

Courtès, Jean, Saint Augustin et la médecine, Augustinus Magister, I, Paris 1954 p. $43 \mathrm{ff}$.

Couturier, C., "Sactamentum" et "Mysterium" dans l'oeudre de saint Augustin, in Rondet, H. - Le Landais, M. - Lauras, A. - Couturrer, C., Eludes augustiniennes, Theologie 28, Paris 1953, p. $161 \mathrm{ff}$.

Gullmann, O., Urchristentum und Gottesdienst, Basel 1950.

Cumont, F., Lux perpetua, Paris 1949.

DAHL, N. A., Anamnesis, Studia Theologica 1, 1948, p. $69 \mathrm{ff}$.

Dantélou Jean, Théologie du Judéo-Christianisme, Bibliotheqque de Théologie, ParisNew York-Rome 1957.

Dantels, A., Devotio, JLW 1, 1921, p. 40 ff.

Deden, D., Le mystere paulinien, Ephemerides theol. Lovanienses 13, 1936, p. $403 \mathrm{ff}$.

Derkers, E., Tettullianus on de geschiedenis der liturgie, Catholica VI, 2, BrusselAmsterdam 1947.

-, De humilitate, Horae monasticae, I, Tielt 1947, p. $67 \mathrm{ff}$.

Delehaye, Hippolyte, Les origines du culte des martyrs, Bruxelles 1912.

-, Sanctus, Studia Hagiographica XVII, Bruxelles 1927. 
Drehl, Ernestus, Inscriptiones Latinae christianae veteres", I-III, Berlin 1961.

Diezrnger, WAlter, Effectus in der römischen Liturgie. Eine kultsprachliche Untersuchung, Theophaneia 15, Bonn 1961.

Dirksen, A. H., The New Testament Concept of Metanoia, S. Facultas Theologica 34, Washington, D.C. 1932.

Dirksen, H. E., Thesauri latinitatis fontium iuris civilis Romanorum specimen, Lipsiae 1834.

-, Manuale latinitatis fontium iuris civilis Romanorum, Beroline 1837.

Dix, GR., The Shape of the Liturg $y^{2}$, Westminster 1945.

Dold, A., Zwei neus Sakramentarfragmente. Fragmentum Stuttgardianum aus Cod. H B I Asc 227 und Fragmentum Beuronense 2, JLW 7, 1927, p. $136 \mathrm{ff}$.

一, Liturgische Reminiszenzen in einem Sermo Leo d. Gr., JLW 7, 1927, p. 125 ff.

-, Die ursprüngliche Fassung der Postcommunio "Protegat nos Domine" und ihre Verwendung zur Ehren St. Benedikts, Benedikt. Monatschr. 15, 1933, p. $152 \mathrm{ff.}$

Dölger, F. J., Der heilige Fïsch in den antiken Religionen und im Christentum, II, Münster in Westr. 1922.

-, Sol Salutis. Gebet und Gesang im christlichen Altertum, Münster in Westf. 1925.

-, Kaiser Theodosius der Grosse und Bischof Ambrosius von Mailand in einer Auseinandersetzung zwischen Predigt und Messliturgie, Antike und Christentum 1, 1929, p. 54 ff.

-, Der Heiland, Antike und Christentum 6, 1950, p. $241 \mathrm{ff}$.

Dolle, Rene, Lion le Grand. Sermons, I-III, SC 22, 49, 74, Paris 1947-1961.

DoRen, R. vaN, L'oraison "fidelium" du Lundi, QLP 10, 1925, p. $102 \mathrm{ff}$.

Dörfler, P., Die Anfänge der Heiligenverehrung nach den römischen Inschriften und Bildwerken, München 1913.

Du CANGe, Glossarium mediae et infimae latinitatis, I-VII, Paris 1840-1850.

Duchesne, L., Le Liber pontificalis, I-II, Paris 1886-1892.

-, Origines du culte chretien, Paris 1908.

DürIG, W., Der Begriff pignus in der römischen Liturgie, ThQ 129, 1949, p. 385 ff.

-, Die Evforschung der lateinisch-christlichen Sakralsprache, LJ 1, 1951, p. 32 ff.

-, Imago. Ein Beitrag zur Terminologie und Theologie der römischen Liturgie, Münchener theol. St. II, 5, München 1952.

-, Pietas liturgica. Studien zum Frömmigkeitsbegriff und zur Gottesvorstellung der abendländischen Liturgie, Regensburg 1958.

Dutrupon, F. P., Concordantiae Bibliorum Sacrorum vulgatae editionis ad recognitionem jussu Sixti V Pontif. Max., Paris 1844.

Dwyer, Wultam F., The Vocabulary of Hegesippus. A Study in Latin Lexicography, Patristic Studies 27, Washington, D.C. 1931.

Eijкenвoom, P. C. J., Het Christus-medicusmotief in de preken van Sint Augustinus, Assen 1960.

Eizenhörer, L., Das Opfer der Gläubigen in den Sermonen Leos des Grossen, in ArNold, Fr. X. - Fischer, B., Die Messe in der Glaubensverkündigung, Freiburg 1950, p. $79 \mathrm{ff}$.

Ellard, G., Devotion to the Holy Cross and a Dislocated Mass-Text, TS 11, 1950, p. $333 \mathrm{ff}$.

Engels, L. J., Observations sur le vocabulaire de Paul Diacte, LCP 16, Nijmegen 1961.

Entralgo, P. Laiv, Das Werk Freuds und das ärtzliche Denken des Frühchristentums, Münchener theologische Zeitschrift 5, 1954, p. $195 \mathrm{ff}$.

Ernout, Alfred, Les elements dialectaux du vocabulaire latin, Paris 1909.

Ernout, A. - Meillet, A., Dictionnaire élymologique de la langue latine. Histoire des motst, Paris 1959.

Federer, K., Liturgie und Glaube, Freiburg 1950. 
FÉrotis, M., Le Liber Ordinum en usage dans l'Église wustgothrque et mozarabe d'Espagne, MEL 5, Pans 1904

—, Le Liber Mozarabzcus Sacramentorum et les manuscrits mozarabes, MEL 6, Paris 1912. Fischer, Bonifatius, Praeceptus salutantus montt, ALW 1, 1950, p. $124 \mathrm{ff}$

Fischer, B - Wagner, J., Paschatus Sollemnza Studien zur Osterfezer und Osterfrommigkett. Festschrift Jungmann, Basel-Freiburg-Wien 1959.

FrTtrau, G, Der Begniff des Mysternums bei Fohannes Chrysostomus Eine Ausenandersetzung mut dem Begruff des "Kultmysterutus" in der Lehre Odo Casels, Theophaneia, 9 Bonn 1953.

Forcellin, A - de Vit, V., Totius latinitatus lexicon, I-VI, Prati 1858-1875.

FraNk, H, Zur Geschichte von Werhnachten und Eprphanie, I-II, JLW 12, 1932, p. 145 ff.; 13, 1933, p. 1 ff

-, Aetroveyia-munus, JLW 13, 1935, p. $181 \mathrm{ff}$.

-, Hodre caelestr sponso iuncta est ecclesia Vom christlichen Mystenum. Festschrift Odo Casel, Dusseldorf 1951, p. $192 \mathrm{ff}$.

-, Fruhgeschichte und Ursprung des romuschen Wethnachtsfestes, ALW 2, 1952, p $11 \mathrm{ff}$.

GHeLlincK, J. DE, Latın chrétzen ou langue latine des chrétzens Les études classiques 8, 1939 , p $449 \mathrm{ff}$.

Ghellinck, J. DE - Backer, E. DE - Poukens, J - Lebacgz, G, Pour l'hustoute du mot sacramentum, I. Les Anténccéens, Spicilegium sacrum Lovaniense 3, LouvainPans 1924.

Goelzer, H , Etude lexicographrque et grammatzcale de la latınté de saint Jérôme, Parıs 1884

Goltz, EDUARD von DER, Das Gebet in der altesten Chrtstenhezt, Leipzig 1901.

Guillaume, A, Jeûne et charnté dans la liturgıe du caréme, NRTh 76, 1954, p. $230 \mathrm{ff}$.

-, Jeûne et charnté, Pans 1954

Guntert, Hermann, Von der Sprache der Gotter und Gewter, Halle 1921.

HaEssly, M. G., Rhetoric in the Sunday Collects of the Roman Mussal, Cleveland, Ohio 1938.

Hagendahl, H., La prose métrtque d'Amobe, Goteborg 1937

Harnack, A. von, Meducinisches aus der ältesten Kirchengeschuchte, Texte und Unters. VIII. Band, Heft 4, Zweite Abhandlung, Leipzig 1892.

-, Militua Chrsti, Tubingen 1905

-, Due Mussion und Ausbrettung des Chrustentums, I-II, Lelpzig 1915

-, Due Terminologie der Wredergeburt und oerwandter Erlebnusse in der altesten Kurche, Texte und Unters 3 Rh 12, 3, Leipzig 1918.

Hauner, Rose Mary, The Late Latin Vocabulary of the Moralza of Saint Gregory the Great. A Morphological and Semaswological Study, Studies in Medieval and Renaissance Latın 7, Washington, D.C 1938.

Havers, Wilhelm, Das indogermantsche Enklusengesetz in den Otationen des Mussale Romanum, Kultur und Sprache, Wien 1952, p. 397 ff.

Henni, John, Kalendar und Martyrologium als Literaturformen, ALW 7-1, 1961, p $1 \mathrm{ff}$.

Herz, Martin, Sacrum Commetcuum Eine begriffsgeschuchtliche Studue zur Theologie der römuschen Liturgzesprache, Munchener theol. St II, 15, Munchen 1958.

Heumann, H. - Seckel, E, Handlexzkon zu den Quellen des romwchen Rechts ${ }^{10}$, Graz 1958.

HoFman,, J. B , Lateintsche Umgangsspraches, Heidelberg 1951.

HoppenbrouWErs, H. A. M., Recherches sur la terminologie du martyre de Tertullzen à Lactance, LCP 15, Nijmegen 1961. 
Hrduicka, C. L., A Study of the Late Latin Vocabulary and of the Prepositions and Demonstrative Pronouns in the Confessions of Saint Augustine, Patristic Studies 31, Washington, D.C. 1931.

Janssen, Harry H., Kultur und Sprache. Zur Geschichte der alten Kirche im Spiegel der Sprachentwicklung. Von Tertullian bis Cyprian, LCP 8, Nijmegen 1938.

Jungmann, J. A. Gewordene Liturgie, Innsbruck 1941.

-, Die Stelleng Christi im liturgischen Gebet', LQF 19-20, Münster in Westf. 1962.

-, Missarum sollemnia. Eine genetische Erklärung der römischen Messes, I-II, Wien 1962.

KaHL, W., Vom Stil liturgischen Betens, LZ 5, 1932, p. $161 \mathrm{ff.}$

KaINz, FrIEdrich, Sprachpsychologisches zum Thema Religion und Sprache, Die Sprache 1, 1949, p. $101 \mathrm{ff}$.

Kamerpeek, J., La dignité humaine. Esquisse d'une terminographie, Neophilologus 41, 1956, p. $241 \mathrm{ff}$.

KeEL, G., Laborare und operari. Verwendungs- und Bedeutungsgeschichte zweier Verben für "arbeiten" im Lateinischen und Gallo-Romanischen, Bern 1942.

Kinnavey, Raymond James, The Vocabulary of Saint Hilary of Poitiets as Contained in Commentarius in Matthaeum, Liber I Ad Constantium and De Trinitate. A Morphological and Semasiological Study, Patristic Studies 47, Washington, D.C. 1935.

KnnNIRey, A. J., The Late Latin Vocabulary of the Dialogues of Saint Gregory the Great, Studies in Medieval and Renaissance Latin 4, Washington, D.C. 1935.

KrTtel, G., Theologisches Wörterbuch zum Neuen Testament, Stuttgart $1933 \mathrm{ff}$.

Klauser, Theodor, Die konstantinischen Altäre der Lateranbasilika, Römische Quartalschrift 43, 1935, P. $179 \mathrm{ff}$.

-, Der Ubergang der römischen Kirche von der griechischen zur lateinischen Liturgiesprache, Miscellanea G. Mercati, I, Studi e testi 121, Città del Vaticano 1946, p. 467 ff.

Koep, Leo, Das himmlische Buch in Antike und Christentum. Eine religionsgeschichtliche Untersuchung zur altchristlichen Bildersprache, Theophaneia 8, Bonn 1952.

Koffuane, G., Geschichte des Kirchenlateins, I. Entstehung und Entwicklung des Kirchenlateins bis Augustinus-Hieronymus, Breslau 1879.

Kosmala, H., Hebräer - Essener - Christen. Studien zur Vorgeschichte der frühchristlichen Verkündigung, Studia Post-bliblica 1, Leiden 1959.

Krebs, J. P. - Schmalz, J. H., Antibarbarus der laleinischen Sprache?, I-II, Basel 19051907.

Kühner, R. - Stegmann, C., Ausführliche Grammatik der lateinischen Sprache,’ I-II, Hannover 1955.

LABriolie, P. DE, Salvator, Mélanges en hommage à la mémoire de Fr. Martroye, Paris 1940, p. 59 ff.

LECLERQ, JeAN, Le latin chretien, langue d'eglise, LMD 11, 1947, p. 55 ff.

LeEman, A. D., Gloria. Cicero's waardering van de roem en haar achtergrond in de hellenistische wijsbegeerte en de romeinse samenleving, Rotterdam 1949.

LEEUWEN, W. S. vaN, Eirene in het Nieuwe Testament. Een semasiologische, exegetische bijdrage op grond van de Septuaginta en de Joodse literaturur, Wageningen 1940.

Liang, Joe Kwa, Het begrip deemoed in I Clemens. Bijdrage tot de geschiedenis van de oudchristelijke ethiek, Utrecht 1951.

LIETzMann, Hans, Das Sactamentarium Gregorianum nach dem Aachener Urexemplar, LQF 3, Münster in Westf. 1921.

-, Messe und Herrenmahl. Eine Studie zur Geschichte der Liturgies, Arbeiten zur Kirchengeschichte 8, Berlin 1955. 
Lörstedt, EiNar, Beiträge zur Kenntnis der späteren Latinität, Uppsala 1907.

-, Spätlateinische Studien, Uppsala 1908.

-, Zur Sprache Tertullians, Lund 1920.

-, Philologischer Kommentar zur Peregrinatio Aetheriae2, Uppsala 1936.

-, Vermischte Studien zur lateinischen Sprachkunde und Syntax, Lund 1936.

-, Syntactica, I², Lund 1942; II, Lund 1933.

-, Coniectanea. Untersuchungen auf dem Gebiete der antiken und mittelalterlichen Latinität, I, Stockholm 1950.

-, Late Latin, Oslo 1959.

Loré, L. Tr. A., The Spiritual Terminology in the Latin Translations of the Vila Antonii, LCP 11, Nijmegen 1955.

Lows, E. A., The Bobbio Missal, Henry Bradshaw Society 53, London 1917.

LyonNet, S., De ieiunio et abstinentia ut fontibus caritatis, Verbum Domini 30, 1952, p. $92 \mathrm{ff}$.

Malone, E., The Monk and the Martyr. The Monk as the Successor of the Martyr, Studies in Christian Antiquity 12, Washington, D.C. 1950.

Mansi, J. D., Sacrorum conciliorum nove et amplissims collectio, reimpression and continuation, I-LIII, Paris-Arnhem-Leipzig 1901-1927.

Manz, G., Ausdrucksformen der lateinischen Liturgiesprache bis ins 11. Jahrhundert, Texte und Arbeiten, Beiheft, Freiburg 1941.

Marouzeau, J., L'ordre des mots dans la phrase latine, I-IV, Paris 1922-1953.

-, Quelques aspects de la formation du latin littéraire, Paris 1949.

-, Traite de slylistique latine", Paris 1954.

Marrou, H.-I., Histoire de l'éducation dans l'antiquite, Paris 1948.

-, Saint Augustin et la fin de la culture antiquet, Paris 1958.

Martmont, A. G., L'Église en priere. Introduction à la liturgie, Paris-Tournai-RomeNew York 1961.

Martun, H., II - Spanish Inscriptions - Additional Comment, Am. Journal of Philology 35,1914 , p. $400 \mathrm{ff}$.

Martindale, C. C., The Mind of the Missal, London 1931.

-, Prayers of the Missal, New York, N.Y. 1938.

-, A Christmas Echo, The Month 185, 1948, p. 116 ff.; p. $379 \mathrm{ff}$.

Matzkow, W., De vocabulis quibusdam Italae et Vulgatae christianis, Berlin 1933.

MeEr, F. van Der, St. Augustine the Bishop. The Life and Work of a Father of the Church, translated from the German (Augustinus der Seelsorger, Köln 1958) by B. BATTERshaw and G. R. LAMB, New York, N.Y. 1961.

Merllet, A., Linguistique historique et linguistique gendrale, I², Paris 1926; II, Paris 1936.

-, Esquisse d'une histoire de la langue latine, Paris 1952.

Merkx, P. A. H. J., Zur Syntax der Kasus und Tempora in den Traktaten des hl. Cyprian, LCP 9, Nijmegen 1939.

MucheLs, Тн., Recensita natioitate, JLW 11, 1931, p. 139 ff.

Mittellateinisches Wörterbuch bis zum ausgehenden 13. Jahrhundert, München $1959 \mathrm{fr}$.

Mohlberg, L. C. - Eizenhöper, L. - Siprrin, P., Sacramentarium Veronense, RED, Fontes I, Roma 1958.

-, Liber Sacramentorum Romae Aeclesiae Ordinis Anni Circuli. (Gelasianum Vetus), RED, Fontes IV, Roma 1960.

-, Missale Gothicum, RED, Fontes V, Roma 1961.

Mohrmann, Ghr., Die altchristliche Sondersprache in den Sermones des hl. Augustin, LCP 3, Nijmegen 1932. 
-, Review of M G. Hasssly, Rhetoric in the Sunday Collects of the Roman Mussal (Cleveland, Ohı 1938), REL 17, 1939, p 414 ff

-, Quelques observations lingutstiques à propos de la nouvelle verston latıne du Psautzer, VC 1, 1947, p $114 \mathrm{ff}$; $168 \mathrm{ff}$.

- Transformations linguzstiques et evolution soczale et spirituelle, VG 1, 1947, p $186 \mathrm{ff}$.

- Le latın commun et le latın des chrétiens, VC 1, 1947, p $1 \mathrm{ff}$

-, Les eléments vulgaıres du latın des chrétrens, VC 2, 1948, $89 \mathrm{ff}, 163 \mathrm{fr}$.

-, Mulver A propos de 2 Reg 1, 26, VC 2, 1948, p. $117 \mathrm{ff}$.

-, Review of Gustave BARDY, La question des langues dans l'Église ancienne, I (Paris 1948), VC 3, 1949, p. $123 \mathrm{fr}$

-, Les ongines de la latinité chrélzenne à Rome, VC 3, 1949, p $67 \mathrm{ff}$; $163 \mathrm{ff}$.

-, Quelques observations sur l'évolution stylistique du Canon de la Messe romaine, VC 4, 1950 , p. $1 \mathrm{ff}$.

-, Le latin liturgique, LMD 23, 1950, p $5 \mathrm{ff}$.

-, Les emprunts grees dans la latinté chrétzenne, VC 4, 1950, p $193 \mathrm{ff}$.

-, Review of G. Callewaert, Saint Léon le Grand et les textes du Léonien (Steenbrugge-'s-Gravenhage 1948), VG 4, 1950, p 125 ff.

-, A propos des Collectes du Psautuer, VC 6, 1952, p $1 \mathrm{ff}$.

一, Statzo, VC 7, 1953, p. $221 \mathrm{ff}$

-, Sur l'histoare de praefan - praefatio, VC 7, 1953, p $1 \mathrm{ff}$

-, A propos de deux mots controversés de la latinzté chrétzenne. Tropaeum - nomen, VC B, $1954, \mathrm{p} 154 \mathrm{ff}$.

-, Problèmes stylzstzques dans la lattérature latine chrétzenne, VC 9, 1955, p. $222 \mathrm{ff}$.

-, Latin vulgaire, latin des chrétzens, Latin médiéval, Parıs 1956.

-, Liturgical Latın Its Ongins and Character, Washington, D C 1957.

-, Linguistic Problems in the Early Christian Church, VC 11, 1957, p. $11 \mathrm{ff}$.

-, Locus refrigern luces et pacts, QLP 3, 1958, p. $196 \mathrm{ff}$.

-, Missa, VC 12, 1958, $\mathrm{P} 67 \mathrm{ff}$.

-, Review of Bernaro Kotting, Peregrinatzo religiosa Wallfahten in der antike und das Pilgerwesen in der alten Karche (Munster in Westf 1950), VC 13, 1959, p $250 \mathrm{ff}$.

-, Etudes sur le latin des chrétuens, I'-II, Roma 1961.

-, Les dénominatzons de l'églzse en tant qu'édifice en grec et en latin au cours des premuers siècles chrétzens, Revue des Sciences religieuses 36, 1962, p. $155 \mathrm{ff}$

Moruv, G., Une énigme liturgique. La postcommunzon de Noël a l'aurore, RB 47, 1935, p. $170 \mathrm{ff}$.

Most, WM, The Syntax of the Vitae Sanctorum Hiberniae, Studies in Medieval and Renaussance Latin 20, Washington, D C. 1946.

Mueller, M. M, The Vocabulary of Pope St Leo the Great, Patristic Studies 67, Washıngton, D C. 1943

Muller, Michael M, Der Uebergang von der gruechwschen zur lateintschen Sprache in der abendländschen Kirche von Hermas bis Novatian Eine historssche Untersuchung uber den Sprachenwandel oom gruechischen zum laternischen Sprachidiom in den Kitchen des chrsstluchen Abendlandes von 150-250, Rome 1943

Norberg, DAG, Syntaktusche Forschungen auf dem Gebrete des Spällateins und des fruhen Mettellatezns, Uppsala 1943.

Norden, EduARD, Die antike Kunstprosa², I-II, Leipzıg-Berlın 1909.

-, Agnostos Theos, Untersuchungen zur Formgeschuchte religiöser Rede, Leipzig-Berlin 1913.

-, Aus altromischen Pruesterbilichern, Lund 1939. 
O'Bruen, Mary Brmget, Titles of Address in Christian Latin Epzstolography to 543 A.D., Patristıc Studies 21, Washıngton, D C 1930.

Odelstierna, I., De vi futurali ac finali genundiz et getundivi latinz observationes, Uppsala 1926.

O'Donnels, J. F., The Vocabulary of the Letters of Gregory the Great, Studies in Medieval and Renaissance Latın 2, Washington, D.C. 1934.

Omme, A. N. Van, "Virtus", een semantuese studu, Utrecht 1946

Oorde, W. van, Lexicon Aetherianum, Amsterdam 1930.

Ozanam, Frédéric, Comment la langue latıne devint chrétrenne, Oeuvres Complètes, II, Paris 1873, p. 133 ff.

Pauly, A. - Wissowa, G. - Kroli, W. - Mrttelhaus, K - Ziegler, K. - John, W., Real-Encyclopadue der classschen Altertumswrssenschaft ${ }^{2}$, Stuttgart 1893 f.

Persson, P., De ongine ac vi primigenua gerundin et gerundivi latını, Skr. utg. av K. Hum. Vetenskaps-Samfundet 1 Uppsala III 4, Uppsala 1900.

Pétré, Hélìne, Cantas. Etude sur le vocabulaire latın de la chantlé chrétrenne, Spicilegium sacrum Lovaniense 22, Louvain 1948.

Pighi, G. B., La poesta religiosa romana. Testz e frammentz per la prima volta raccoltz e tradotti, Bologna 1958.

Prein, J. A. M., De oratie van S. Michael, Tijdschr. voor Lit. 32, 1942, p. $87 \mathrm{ff}$.

Prumu, K., Christentum als Neuhettserlebnrs, Fresburg 1939.

PUNIET, P. DE, "Intus reforman". Témargnages ltturgıques sur le mystère de l'Emmanuel, EL 52, 1938, p. $125 \mathrm{ff}$.

Rheinfelder, HaNs, Zum Stzl der lateinuschen Otationen, JLW 11, 1931, p. $20 \mathrm{ff}$.

-, Kultsprache und Profansprache in den romanuschen Landern, Genève 1933.

-, Confilert, confessio, confessor im Kirchenlatein und in den romanuschen Sprachen, Die Sprache 1, 1949, p. 56 f

Roetzer, W., Des hl Augustinus Schriften als liturgugeschichtluche Quelle, Munster in Westf 1930.

Ronsch, H., Itala und Vulgata. Das Sprachidiom der urchrzsiluchen Itala und der katholsschen Vulgata unter Beruckstchtrgung der romsschen Volkssprache², Marburg 1875.

-, Semaszologische Beitrage zum laternischen Worterbuch, I-III, Leipzig 1887-1889.

Sainto, Matti A, Semasiologusche Untersuchungen uber die Entstehung der chrastlichen Latinttat, Annales Acad Scient. Fennicae XLVII, 1, Helsinkı 1940.

SaInte-Marie, Henri de, Sancti Huetonymi Psalterium iuxta Hebraeos. Edition critique, Collectanea Biblıca Latına 11, Gittà del Vatıcano 1954.

Salmon, P., Les protocoles des orazsons du Missel Romain, EL 45, 1931, p. $140 \mathrm{ff}$.

Salonius, A. H., Vitae patrum. Kritusche Untersuchungen uber Text, Syntax und Wortschatz der spallateineschen Vitae patrum, Lund 1920.

SAussure, F. DE, Cours de Linguestrque génétale ${ }^{2}$, Paris 1922.

Schafer, C. TH, Clementws Romant epistula ad Corinthios quae vocatur prima graece et latzre, FP 44, Bonn 1941.

Schemt, H., Due Taufwasserwerhegebete, LQF 29, Munster in Westf 1935.

Scherman, Theodor, Zur Erklarung der Stelle Epist. ad Eph. 20, 2 des Ignatius von Antrochera, ThQ 92, 1910, p. 6 ff.

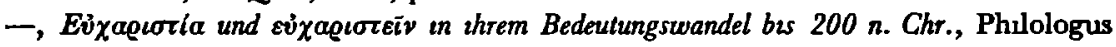
69,1910 , p. $375 \mathrm{ff}$.

ScHMIDT, H., Introductio in liturgiam occudentalem, Roma 1960.

Schnewer, J., Doxa. Etre bedeutungsgeschrchtluche Studze, Gutersloh 1932.

Schnemer, K., Geustesgeschuchte des antrken Christentums, I-II, Munchen 1954. 
Schrujnen, Jos., Dutvelsnamen, Volkskunde 21, 1910, p. $5 \mathrm{ff}$.

-, Uit het Leven der Oude Kerk, Bussum-Utrecht 1919.

-, Charakternstzk des altchrstlizchen Latein, LCP 1, Numegen 1932.

-, Le latin chrétzen devenu langue commune, REL 12, 1934, p. 96 ff.

-, Collectanea Schrignen Versprezde opstellen van Dr. Jos Schrynen, Nymegen-Utrecht1939.

Schrujnen, Jos. - MohrmanN, Ghr, Studien zur Syntax der Brefe des hl. Cyprzan, I-II, LCP 5 \& 6, Nımegen 1936-1937.

Sleumer, Albert, Kirchenlateinusche Wörterbuch", Limburg a d. Lahn 1926.

Sommer, Ferdinand, Handbuch der lateinwshen Laut- und Formenlehre 2 \& 3, Heidelberg 1914.

SoOs, MARIA BeRNARd DE, Le mystite liturgaque d'après saint Leon le Grand, LQF 34," Munster in Westf 1958.

Souter, A., A Glossary of Later Latin to 600 A.D., Oxford 1949.

Spanneut, M., Le Stoicesme dés Petres de l'Eglwe. Patristica Sorbonensia 1, Paris 1957.

Stelnhermer, M., Du $\triangle O \Xi A$ TOY $\Theta E O Y$ in der römischen Liturgu, Munchener theol. St. II, 4, Munchen 1951

Stolz, Fr - Schmalz, J. H. - Leumann, M - Homann, J. B., Latennwshe Gramma$t i k^{5}, \mathrm{I}-\mathrm{II}$, Munchen 1926-1928

STrecker, K, Introduction to Medieval Latın. English Translation and Revision by R B. Palmer, Berlun 1957.

Svennung, J., Oroszana. Synlaktzsche, semastologische und kntzsche Studien zu Orostus, Uppsala 1922.

-, Untersuchungen zu Palladius und zur latennschen Fach- und Volkssprache, Uppsala 1935.

Teeuwen, ST. W. J., Sprachlucher Bedeutungswandel bet Tertullaan, Studien zur Geschichte und Kultur des Altertums 14, 1, Paderborn 1926

Traube, Ludwig, Vorlesungen und Abhandlungen, herausgegeben von Franz Boll, I-III, Munchen 1090-1920.

Thierbach, Alpred, Untersuchungen zur Benennung der Kurchenfeste un den romanzschen Sprachen, Deutsche Akademue der Wissenschaften zu Berln, Veroffentlichungen d. Instituts f. Roman. Sprachwissenschaft 6, Berlin 1951.

Vagagorni, Cypren, Inutzation théologrque à la liturgue, adapted from the Italıan (Il senso teologico della Liturgia , Roma 1958), by Phlippe Roullard, Bruges-Paris 1959.

VANDenbroucke, F, La collecle pour la féte de S. Michel. Son sens, son orngıne, QLP 25, 1940 , p. $163 \mathrm{ff}$.

Vermeulen, A. J., The Semantuc Development of Gloria in Early-Chrustzan Latin, LCP 12, Numegen 1956.

VILLER, M , Dictionnarre de Spintualtte, Paris $1932 \mathrm{ff}$.

Walde, A. - Hofmann, J. B., Latetnusches etymologusches Worterbuch ${ }^{3}$, I-II, Heidelberg 1938-1954.

Wener, Robert, Le Psautret Romann et les autres anczens Psautrets Latzns. Édztron orntrque, Collectanea Bıblıca Latına 10, Cuttà del Vatıcano 1953.

Weinreich, Uriel, Languages in Contact Findings and Problems, New York, N.Y. 1959.

Weisgerber, L, Die Stellung der Sprache im Aufbau der Gesamtkultur, Worter und Sachen 15, 1933, P. 134 ff.

Wrson, H. A., The Gregornan Sacramentary under Charles the Great, Henry Bradshaw Society 49, London 1915.

Wissowa, G, Religion und Kultus der Römer, Munchen 1912.

Ysenaert, J., Greek Baptzmal Terminology. Its Ongins and Early Development, GCP 1, Nijmegen 1962. 


\section{INTRODUCTION}

Before beginning the actual work of setting down remarks on the vocabulary of the ancient orations in the Missale Romanum, it may be well to give a definition of terms and to delimit the subject matter. As the first word of the title of this thesis indicates, the present study makes no pretensions of being an exhaustive investigation of all the words found in the orations. Such a task would require research which would far exceed the limits of a single volume. Rather do we plan simply to trace some of the broad trends noticeable in the vocabulary of these prayers. First we shall study the typical "Christianisms" in order to determine how great a role these play in this section of the official euchologyl. Under the heading, "Terms Which Have a Technical Liturgical Sense", will be included the words which refer specifically to the Eucharist, those which indicate the cultic act in a more general way, prayer terms, and also some characteristic expressions for the effects of the cultic act. Although, strictly considered, all of these belong to the "Christianisms", still we shall study them in a separate section, because they belong also to the more restricted group which we may call "liturgical technical terms". A consideration of the borrowings from several "group languages" will follow next in order. A few pertinent remarks on the Biblical elements will be the content of the final chapter.

In general we shall follow the same system throughout, i.e., immediately following the word under consideration, we shall add one or more English equivalents thereof. It must be borne in mind, however, that there will be times when these translations will not cover all the nuances appearing in the subsequent discussion. Deviations from this system will be made in the case of mysterium, sacramentum, and a few other words referring to the Eucharist as such. The reason for these exceptions will at once be evident when one takes into consideration the breadth of meaning contained in these terms.

1 The word "Christianisms" includes those terms which either were designedly coined or were given a new meaning in order to convey some concept which is specifically Christian. 
Essentially a vocabulary study, this work will deal with stylistic elements in so far as these affect the choice of words. The subject of the rhythm of these prayers, though it would be a most rewarding study, must be set aside here, for it, too, would be material for a volume apart. ${ }^{1}$ Rhetorical figures play an extraordinarily important part in the construction and choice of words in the ORATIONs. In this field a work has already been published; viz., M. G. HaEssLy, Rhetoric in the Sunday Collects of the Roman Missal, Cleveland, Ohio 1938.

We shall use the word orations (so printed in capital letters) througout this work to include the collects, secrets, postcommunions and prayers over the people, as well as the prayers of some blessings if these are labelled oratio in the MR. The function of the orations, being in most cases to conclude periods of silent prayer at the close of three high points in the liturgical act - Introit, Offertory, and Communion - gives them a certain similarity of character. Furthermore, these prayers have come forth from a long tradition of improvisation, which in turn gave way to formularization. And thus the linguistic affinity, which resulted from the constant re-use of favorite expressions and turns of speech, justifies our studying them as a group ${ }^{2}$.

To indicate what is included in the term "ancient" will require a somewhat more detailed explanation. The liturgy of the Church of Rome was at first celebrated in Greek, even as the earliest preaching and the earliest literature were also Greek ${ }^{3}$. This situation was brought about partly by the fact that the first converts to Christianity were made, for a large part, from within the Hellenistic Jewish communities; but even more because the Korne Greek was the language, not only of the Eastern part of the Roman Empire in the first century of our era, but also of the numerous oriental proletariat, the "displaced persons", who were scattered throughoutall the important centers of the

1 Cf. p. 17, note 2, for some pertınent bibliography on this subject. Furthermore, H. Hagendahl in La prose metrique d'Amobe, Goteborg 1937, gives evidence that the prose rhythm had a definite influence on vocabulary.

Cf. Chr. Mohrmann, Liturgucal Latin Its Ongins and Character, Washington, D.C. 1957, p. 77.

s Cf. Michael M. Muller, Der Uebergang von der grechischen zur latennschen Sprache in der abendlandwschen Kirche von Hermas bus Novatzan Ein historzsche Untersuchung uber den Sprachenwandel vom grzechwschen zum lateinuschen Sprachidiom in den Kirchen des christlichen Abendlandes von 150-250, Rome 1943, p. 4 f., esp. p. 7 ff.; Theodor Klauser, Der Ubergang der romuschen Kirche von der gruchuschen zur lateinuschen Liturgiesprache, Miscellanea G. Mercatı, I, Città del Vaticano 1946, p. 467 ff ; G. BARDY, La question des langues dans l'Eglwe ancrenne, I, Parss 1948, p $52 \mathrm{ff}$., esp $81 \mathrm{ff}$; Chr. Mohrmann, Les ongines de la latınté chrétrenne à Rome, VC 3, 1949, p 67 ff.; 163 ff., esp. $67 \mathrm{ff}$. 
West" ${ }^{1}$. It is obvious, though, "that the process of converting the Christian body of ideas into Latin began from the moment when people whose mother tongue was Latin adopted Christianity"2. Although this Latinizing must have begun very early in Rome, it did not affect the liturgy until later. Theodor Klauser, in seeking the reason why the change from Greek to Latin in the liturgy came about so late, draws attention to the fact that it is of the nature of the liturgy to be conservative $^{3}$. This is particularly true of the Roman liturgy; for, as Eduard Norden has so ably demonstrated ${ }^{4}$, the Romans were from earliest times accustomed to archaic cultic forms. Witness, for example, the Hymn of the Arval Brethren or the prayer used by Augustus in the year 17 B.C., on the occasion of the Ludi Saeculares ${ }^{5}$.

Just when did the Roman liturgy become Latinized? It was undoubtedly a gradual process, with some parts; viz., the readings and the Psalms, being conducted in the vernacular earlier than other parts. And it certainly did not become effective everywhere at the same time. On this point Jungmann says: "Wenn es in Rom schon vor Konstantin über 40 Kirchen gab, so werden griechische Minoritäten auch weiterhin ihren griechischen Gottesdienst gehabt haben, ebenso wie lateinische Gemeinden auch schon vor Cornelius bestanden haben mögen"•. Still there seems to be some evidence that there was a final shift from Greek to Latin in the Eucharistic liturgy in the second half of the fourth century?.

In addition, Professor Chr. Mohrmann has shown from philological arguments, that is is plausible to infer that the transition took place about this time. A liturgical language, being hieratic, is necessarily stylized. The Romans' feeling for stylized elements was especially deep. Hence a Latin liturgical language would have been unthinkable before Christian Latin had become a fully developed literary language. Then, too, it was only after the victory over paganism through the freedom of the Church under Constantine that the Christians became less scrupulous about adopting words which had pagan sacral connotations. Thus,

1 Cf. Chr. Mohrmann, Le latin langue de la Chrétienté occidentale, Etudes, I', p. 51 ff., esp. 52 ff.; BARDY, La question des langues, p. 83.

- Cf. Bardy. La question des langues, p. 83; Ghr. Mohrmann, Linguistic Problems in the Early Church, Etudes, I², p. 103 ff., ref. to p. 109.

- Cf. Klauser, Miscellanea G. Mercati, I, p. $472 \mathrm{ft}$.

- Cf. Eduard Norden, Aus altrömischen Priesterbïchern, Lund 1939, passim.

6 Cf. G. Appel, De Romanorum precationibus, Giessen 1909, p. 26, and $9 \mathrm{f}$.

- Missarum Sollemnia. Eine genetische Erklärung der römischen Messes,, (I-II, Wien 1962), I, p. 65.

7 Cf. Jungmann, Missarum Sollemnia ${ }^{5}$, I, p. 64 ff.; Mohrmann, Liturgical Latin, p.50 ff. 
"the whole development of language and style, together with the changed attitude of the Christians toward the pagan culture, helped to make it possible for a liturgical language to arise in the second half of the fourth century"1.

The terminus a quo, then, of the "ancient" orations is the time of the Latinizing of the Roman liturgy. That the earliest sources, however, stem from the sixth or seventh century ${ }^{2}$ by no means indicates that the prayers themselves were composed in those centuries.

As the terminus ad quem, we have set the manuscripts of the eleventh century. This may seem at first sight to be a somewhat arbitrary arrangement. But there are both liturgical and philological factors which have helped to influence this choice. The custom of improvisation and even formularization in the liturgy had come to an end by the middle of the sixth century. According to the plausible theory of A. Chavasse, the spirit of organization peculiar to the sixth century, led to the arrangement of "sacramentaries"3. The first of these, the Veronense, a compilation of a series of prayers for various feasts, came into existence about 650 . The Gregorianum, a papal sacramentary, probably had its origin around the beginning of the seventh century; and the presbyterial sacramentary known as the Gelasianum Vetus, shortly after the middle of the seventh century. The period from the eighth to the eleventh century was one in which there was a fusion of innumerable Roman and non-Roman elements. A glance at the list of Sources in Placide Bruylants, Les oraisons du Missel Romain, I, p. xi-xiv, will reveal that the latest manuscript of a sacramentary is the Cod. Ross. Lat. 204 , from the middle of the eleventh century. For the sake of completeness, we have included the Lateran Missal, since it stems from the XIXII century.

With regard to the philological factors, it must be borne in mind that there existed a continuity between the Latin of Late Antiquity and Medieval Latin 4 , which justifies our studying as a group the prayers composed up to and including the eleventh century. This continuity came about chiefly because the system of education was essentially the same as that which had been current in Antiquity. Although pagan

1 Cf. Mohrmann, Liturgical Latin, p. 52 f.

- Cf. the following note.

- Cf. A. Chavasse, Le Sacramentaire gellasien, Vatic. Regin. 316. Sacramentaire presbyterial en usage dans les Titres romains au VIIe s., Paris-Tournai-New York-Rome 1958, passim, esp. p. $679 \mathrm{ff}$.

- Cf. Chr. Mohrmann, Le dualisme du latin médiéval, Latin vulgaire, Latin des chretiens, latin médiéval, Paris 1956, p. $47 \mathrm{ff}$. 
authors were, to some extent at least, supplanted by the Bible and Patristic literature as the basis of instruction, still the rhetorical devices and the school rules of grammar continued to be exercised'. This state of affairs was kept alive constantly through the various "renaissances" which strove ever to bring the Latin of the schools and of higher culture into line with the norms set down in the existing handbooks. A second factor is the character of liturgical Latin itself. As we have already mentioned, it was from the outset hieratic and soon became very traditional. This traditionalism renders it relatively impossible to determine from the language or style of a given prayer the date of its composition.

As text for this work, we have used the critical edition of Placide Bruylants, Les oraisons du Missel Romain, I-II, Louvain, 1952. Because we have set two criteria for the prayers to be included in this study, namely, (1) that they appear in the present MR, and (2) that they be found in the manuscripts up to and including the eleventh century, there are some instances of prayers which, even though they have made their appearance in the MR comparatively late, have been included here because they appear in the MSS of the sacramentaries. Again, there are many ancient prayers which could not be included because they are no longer found in the MR. Finally, there are a few instances where a prayer in the present-day Missal is composed of parts of two ancient prayers; these, too, have been included here. A list of the oRATIONs studied appears on page $204 \mathrm{ff}$.

1 Cf. H.-I. Marrou, St. Augustin et la fin de la culture antiqued, Paris 1958, p. 3 ff., 46 ff., esp. $89 \mathrm{ff}$. 



\section{“CHRISTIANISMS" IN THE ORATIONS}

Since the topic of "Christianisms" - direct and indirect, lexicological and semantic, integral and partial - has been so clearly defined and so adequately illustrated in other places ${ }^{1}$ that it has now been universally accepted as an important phenomenon in the development of the structure of the Latin language itself, we shall not be obliged here to enter into the detail of its definition nor its history. We shall limit ourselves to an investigation of the Christianisms in the ORATrons.

This latter is a subject of vital interest; for the material is part of the official worship itself. Hence one could hardly find a topic which by its very nature is more Christian. In this study we hope to see something of the relation between the colloquial vocabulary of the earliest Christian "Sondersprache" and the solemn hieratic language used in the liturgy. In the present chapter we shall treat the more "general" Christian terms, whereas those which have a technical liturgical meaning will be discussed in Chapter II.

\section{A. DIRECT CHRISTIANISMS}

Under this heading are included the concepts which have a direct relation to the doctrine, institutions, or practices of Christianity, such

1 Some of the most important bibliography on this topic is the following: Jos. Schrijnen, Charakteristik des alchristlichen Latein, Nijmegen 1932; Collectanea Schrijnen. Verspreide opstellen van Dr. Jos. Schrijnen, Nijmegen-Utrecht 1939; Chr. Mohrmans, Die altchristliche Sondersprache in den Sermones des hl. Augustin, I: Lexikologie und Wortbildung, Nijmegen 1932; Etudes sur le latin des chretiens, $\mathrm{I}^{2}$ Etudes géntrales sur la latinité chretienne, Roma 1961 (This volume contains an up to date list of the publications of Professor Mohrmann, cf. p. ix ff.), 11 Latin chrétien et médiéval, Roma 1961; Liturgical Latin. Its Origins and Character, Washington, D.C. 1957; B. Botre-Chr. Mohrmann, L'ordinaire de la Messe. Texte critique, traduction et études, Paris-Louvain 1953. To date sixteen volumes have appeared in the series: Latinitas Christianorum Primaeva. Studia ad sermonem latinum Christianum pertinentia, instituit Jos. Schrijnen, edenda curant Chr. Mohrmann, et H. H. Janssen, Nijmegen 1932 ff.; and one of the series: Graecitas Christianorum Primaeva. Studia ad sermonem graecum pertinentia, edenda curant Chr. Mohrmann et J. G. A. Ros, S.J., Nijmegen 1962. 
as Salvator, ecclesia, gloria, and the like. Sometimes these words are borrowed from the Greek. This is the case frequently with names of permanent institutions and offices of Christianity, e.g., baptisma, episcopus. At other times native Latin words are employed to convey Christian concepts. These latter may, in turn, be subdivided into two groups. On the one hand there the new-forms-words which were coined by the Christian communities, Bible translators and other Christian authors in order to give expression to specifically Christian ideas, for example, sanctificare. And then there are the existing Latin words which underwent semantic change by their being used to convey Christian thought. This last group is, as we shall see later, by far the largest.

\section{Loanwords}

ABBAs, abbot, head of a religious community ${ }^{1}$.

This word occurs in the ORATIONS only in the collect, $651^{2}$, postcommunion, 915, and secret, 1019, of the Mass for St. Benedict. A loanword from the Hebrew, it replaced pater monasterii as the title of the head of the monastery. It was used by Jeromes, Cassian ${ }^{4}$, and Benedict ${ }^{5}$ regularly for religious superior".

ANGELICUS; see p. 63.

ANGELUS, angel?.

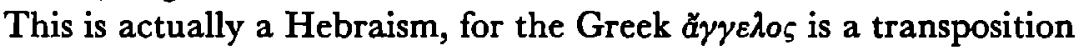
of the Hebrew $m l$ ' $k$, "messenger". It occurs in 208, 320, 387, 575, 769, 972.

APOSTOLICUs; see p. 63.

APOSTOLUS, apostle ${ }^{8}$.

It would seem unnecessary to list all the instances of this Greek loanword. In every case it is employed in the technical sense of one of the "twelve apostles". There is no trace of the broader Early Christian

1 Cf. Mittellateinisches Wörterbuch, I, p. 9.

2 Numbers represent those used by P. Bruylants, Les oraisons du Missel Romain, II, Louvain 1952. Refer to our table, Appendix, p. $204 \mathrm{ff}$., in order to find where the respective prayers are found in the MR.

3 Vita Malchi 3.

Inst. 5, 39.

Reg. 64, e.g.

- Cf. L. Th. A. Lorie, Spiritual Terminology in the Latin Translations of the Vita Antonii, Nijmegen 1955, p. 59.

? Cf. Mohrmann, Etudes, I', p. 47; Sondersprache, p. 79, 108.

- Cf. Mohrmann, Etudes, ${ }^{2}$, p. 42, 62, 89, 117, 156; Sondersprache, p. 82 f. 
meaning of the word áxó $\sigma \tau o \lambda o s$ as anyone who preached the Gospel, as we find it, for example in Didache 11,$3 ; 11,4 ; 11,6^{1}$. The orations stem from a period when the earliest meaning was no longer in use and the later development - whereby the missionaries were called apostles had not yet taken place.

ARCHANGelUs, archangel, the chief of the messengers of God. ${ }^{2}$

It is interesting to note that this Greek loanword is used in connection with the personal name only of Michael: beati Archangeli tui Michaelis intercessione, 72. The feasts of Ss. Gabriel and Raphael are of later origin and thus not included in this study. It occurs also once in a very general connotation: sanctorum Angelorum atque Archangelorum nobis prodesse... auxilio, 972.

BAPTISMA, Baptism ${ }^{3}$.

This technical term for the institution, which marks the first step in the Christian initiation rite, occurs four times: fons baptismatis, 754, 777; baptismatis mysterio, 803; baptismate renovati, 1126. Two comments are in place here. (1) This noun appears always in the Greek form, never with the Latin ending in -us or -um. (2) Though lavacrum is rare in the sacramentaries, it does appear in the invitation to the prayer for the catechumens ${ }^{4}$, where baptism is called lavacrum regenerationis.

BAPTISTA, John the Baptist ${ }^{5}$.

This Greek loanword with a Latin ending was long used side-by-side with baptizator as the nomen auctoris indicating "the one who baptizes". In the ORATIONs it is used exclusively with the name John, 73, 142, 701, 1074 , and thus it shows the later semantic development whereby baptista came to be the technical, almost the proper name for the great Precursor of Christ.

CATECHUMENUS, a catechumen ${ }^{\theta}$.

This Greek loanword used for a time beside audientes and auditores was probably the original term used to designate one preparing to become a Christian. Its use in the orations: auge fidem et intellectum

1 Cf. G. J. M. Bartrlink, Lexicologisch-semantische studie over de taal van de Apostolische Vaders. Bijdrage tot de studie van de groeptaal der Griekse Christenen, Nijmegen 1953, p. 90.

2 Albert Blalse, Dictionnaire latin-frangais des auteurs chrétiens, Strasbourg 1954.

3 Cf. Mohrmann, Etudes, I2, p. 24; Sondersprache, p. 83 ff.; ST. W. J. Teeuwen, Sprachlicher Bedeutungswandel bei Tertullian, Paderborn 1926, p. 47 f.; J. Ysebaert, Greek Baptismal Terminology. Its Origins and Early Development, Nijmegen 1962, p. 65 ff.

- Orationes Solemnes, Fer. VI in Pass. et Morte Dom. 5a.

5 Cf. Monrmann, Eiudes, I'2, p. 44; II, p. 26 f.; Sondersprache, p. 83 ff.

- Cf. Mohrmann, Sondersprache, p. 90 f.; Teeuwen, op. cit., p. 121. 
catechumenis nostris, 777 , does not reveal any trace of the distinction between catechumeni and competentes which was current in the fourth century in part of the Western Church. It is here simply the usual technical term for those preparing for baptism.

catholicus, a Christian, a true believer ${ }^{1}$.

It is interesting to note that this word, which as an adjective, early came to mean "orthodox"2, occurs only once in the orations: Pro animabus famulorum, famularumque tuarum, et omnium catholicorum... in Christo dormientium, 892. It is to be noted further that catholicus is not included in this prayer in the Gel. Vetus nor in the Sacramentary of Prague (dating from the eighth century), but makes its appearance for the first time in the Alcuin Appendix to the Gregorianum ${ }^{3}$. The infrequency of the word is, no doubt, due to the fact that there was no need, in the course of the official worship, to distinguish between true believers and heretics.

coApostolus, fellow-apostle

This noun, which seems to have found its way into Christian Latin shortly before the time of Augustine, occurs but once, namely, in the collect for the votive Mass of Ss. Peter and Paul: Deus, cujus dextera beatum Petrum... erexit, et coapostolum ejus Paulum... liberavit, 212. Compounds with the prefix con-, co-, were quite numerous in Christian Latin probably because this combination provided a convenient means of translating Greek compounds in $\sigma v \eta$-. But the formation was specifically a Latin one, as one can determine from such words as conserous, coaequare, and the like.

DIABOLICUS; see p. 64.

DIABOLus, the devil5.

This loanword from the Hebrew occurs in the following phrase: contra omnes diaboli nequitias dexteram... extende, 66 . It is worthy of note that this "proper name" of the devil is found but once in the orations, while its synonyms, inimicus (208, 438, ) and hostis (36, 174, 196, 666,

1 Cf. Harry H. Janssen, Kultur und Sprache. Zur Geschichte der alten Kirche im Spiegel der Sprachentwicklung. Von Tertullian bis Cyprian, Nijmegen 1938, p. 13 ff.; Mohrmans, Sondersprache, p. $92 \mathrm{f}$.

- Cf. Janssen, op. cit., p. 15 cites passages from Tertullian (Adv. Marc. 3, 22; 3, 21 ; $4,9)$ where catholicus means "true, real".

- Cf. BRuYLANTs, Les oraisons, II, p. 254, apparatus criticus.

- Cf. Ferdinand Sommer, Handbuch der lateinischen Laut- und Formenlehre $2 \& 3$, Heidelberg 1914, p. 302; Mohrmann, Sondersprache, p. 97 f.

- Cf. Mohrmann, Sondersprache, p. 99 ff. 
$1158,1184)$ are more frequent. This may be explained partially, at least, by the fact that there exists a certain religious taboo against pronouncing the devil's name ${ }^{1}$. Thus, especially in the colloquial language, the synonyms became almost technical terms, which in the course of time found their way also into the literary language.

ECCLESIA, the Church ${ }^{2}$.

It seems unnecessary to quote all of the \pm 42 instances of this word. However, a few of the striking ones will be noted: $a b$ Ecclesia tua cunctam repelle nequitiam, 59; Ecclesiae tuae praeesse voluisti, 239; ut Christi et Ecclesiae sacramentum praesignares in foedere nuptiarum, $434 ;$ Ecclesiae tuae... preces... admitte, 517; quem totius Ecclesiae praestitisti esse pastorem, 576 b; cujus spiritu totum corpus Ecclesiae sanctificatur et regitur, 758; Ecclesia tua

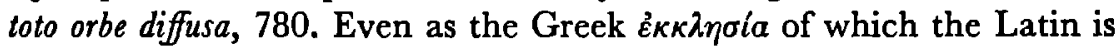
a transliteration, ecclesia may refer to the individual Christian community as well as to the Church as a whole ${ }^{3}$. Its meaning in the ORATIONS seems for the most part to be very close to that of $\dot{\varepsilon} \kappa \kappa \lambda \eta \sigma i a$ in the LXX, where it is the technical translation for Quahal Jahweh - the people of Jahweh assembled before His face for cultic or other purposes ${ }^{4}$. Thus ecclesia refers usually to the individual congregation assembled at a given place for the worship of God. This is in harmony with the concrete character of liturgical Latin. Such, for example, is $576 \mathrm{~b}$, quoted above. This prayer appears first in the Sacramentarium Veronense for the feast of Ss. Peter and Paul ${ }^{5}$, where it was found necessary to add the word totus in order to indicate that these two princes of the apostles were constituted shepherds of the entire Church and not of the local Church at Rome alone. The word means Church as a whole in 434 where it has

1 Cf. Jos. Schrijnen, Duivelsnamen, Volkskunde 21, 1910, p. $5 \mathrm{ff}$.

2 Cf. JAnssen, op. cit., p. 7 ff.; Mohrmann, Études, I², p. 42, 62, 89, 117.

$\checkmark$ Cf. Bartelink, op. cit., p. 104.

- Cf. Hans Kosmala, Hebräer, Essener, Christen. Siudien zur Vorgeschichte der frühchristlichen Verkündigung, Leiden 1959, p. $62 \mathrm{ff}$. This author takes exception to the traditional explanation of $\varepsilon \kappa \kappa \lambda \eta \sigma l a$ as being the Christian counterpart of the LXX translation of the Hebrew Quahal Jahweh. Since already in the earliest records of Christianity $\varepsilon \kappa \kappa \lambda \eta \sigma i a$ was used to designate the individual Christian community, with no indication that the Church as a whole was the counterpart of the Quahal Jahweh as this term was used at the time of Christ, Kosmala seeks in the language of the Essenes the source of the word. He maintains that 'edah was the Hebrew word employed to designate this "chosen portion" of the People of Israel, and hence concludes that the Christian usage of $\varepsilon \kappa \kappa \lambda \eta \sigma l a$ must have derived from 'edah rather than from qahal.

- L. C. Mohleerg-L. EizenhöfER-P. Sifrrin, Sacramentatium Veronense, Roma 1956, 316. N.B. All references to this source will hereafter be made simply as MoHLBERG, Veronense. Numbers represent those given to the prayers in this edition. 
the same sense that it has in Ephesians 4, 23-32. Strikingly enough the word never appears in the ORATIONs in the sense of "church building". Professor Mohrmann in an article entitled: Les dénominations de l'église en tant qu'édifice en grec et en latin au cours des premiers siècles chrétiens ${ }^{1}$, gives an account of the displacement of sense from ecclesia as "the Christian community" to its concrete meaning of "church building". Even in titles of prayers, the word ecclesia does not appear, but the technical term basilica is employed. The first time that the phrase: Dies annuae ecclesiae dedicationis, appears is in the Fragment of Beuron 2 which dates from the middle of the eleventh century ${ }^{2}$.

\section{EPISCOPUS, bishop}

This Greek loanword, which early became so firmly anchored in Latin that it was never replaced entirely by a Latin equivalent ${ }^{3}$, is used in the ORATIONS actually for only two occasions. These are the feast of St. Donatus, where it occurs in the collect, 464, and the secret, 846 , and the Votive Mass for a deceased bishop, where it occurs in all three prayers, $161,608,54-4^{4}$.

EVANGELICUS; see p. 65.

EVANGELISTA, evangelist ${ }^{5}$.

This noun, which is a transliteration of $\varepsilon \dot{v} a \gamma \gamma \varepsilon \lambda \iota \sigma \tau \eta \dot{f} 5$, is used in Acts 21, 8 and Tim. 4, 5 for one who preaches the Gospel. Its use in the ORATIONS reveals a later semantic development of the word, for in every instance it has the technical sense of "author of one of the four Gospels", $69,74,297,520,653,871,1096,1138$.

HAERETICUS; see p. 66 .

ISRAELITICUS; see p. 66 .

MARTYR, a martyr ${ }^{6}$.

It seems unnecessary to quote the numerous instances of this technical term for "one who has died for the Faith".

1 Revue des sciences religieuses 36, 1962, p. $155 \mathrm{ff}$., esp. $159 \mathrm{ff}$. and $173 \mathrm{f}$.

1 Cf. A. DoLD, Zwei neue Sakramentarfragmente. Fragmentum Stuttgardianum aus Cod. H B I Asc 227 und Fragmentum Beuronense 2, JLW 7, 1927, p. $136 \mathrm{ff}$.

- Cf. Mohrmann, Sondersprache, p. 108 ff., 96.

- Cf. pontifex, p. 140.

- Cf. Blaise, Dictionnaire, p. 317; Bartelnnk, op. cit., p. $111 \mathrm{f}$.

- Cf. B. Botte, Confessor, Alma 16, 1942, p. 137 ff.; H. Rheinfelder, Confiteri, confessio, confessor im Kirchenlatein und in den romanischen Sprachen, Die Sprache 1, 1949, p. 56 ff.; H. A. M. Hoppengrouwers, Recherches sur la terminologie du martyre de Tertullien à Lactance, Nijmegen 1961, passim. 
MARTYRIUM, martyrdom, liturgical celebration on the anniversary of a martyr's death'.

Like martyr this term was adopted with a very technical aim. It expressed concretely the fact of dying for the Faith. Such is its meaning in: Deus, qui... etiam in sexu fragili victoriam martyrii contulisti, 376, and sacrificium illud offerimus, de quo martyrium sumpsit omne principium, 642. It doesn't seem plausible to us to interpret martyrium in this latter instance as the "Leidensfeier" or "Martyrermysterium" of the martyrdom, because there is reference to that Sacrifice which is the source of all martyrdom ${ }^{2}$. The word could, however, be used by metonymy for the liturgical celebration in honor of martyrdom in: Deus... qui hunc diem beati Apollinaris... martyrio consecrasti, 225; and Deus, qui hodiernam diem Apostolorum tuorum Petri et Pauli martyrio consecrasti, 352. But the word could refer also to the historical event which is being officially celebrated.

\section{Paraclitus, The Holy Spirit ${ }^{3}$.}

This term for the Holy Spirit, which occurs in John 14, 16 and 15, 26, is found only once in the orations: Mentes nostras... Paraclitus... illuminet, 679, and only once in the Veronense ${ }^{4}$.

Paradisus, paradise.

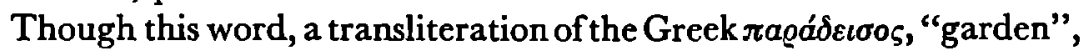
originally referred to the earthly Paradise, it was also applied to the place where the just souls awaited admission into heaven. Thus there is the word of Christ: Hodie mecum eris in Paradiso in the Vulgate, Lk. 23, 43. Its use in conjunction with patriam indicates that it refers to heaven in a collect for the departed: jubeas eam... ad patriam paradisi perduci, 208.

Paschalis, pertaining to the Pasch; pertaining to Easter ${ }^{\mathrm{\theta}}$.

This adjective, formed from the Hebrew loanword pascha, displays in the orations a later stage of semantic development; for there is no trace of that wavering between the interpretation of pascha as transitus, "passover", and the popular etymological interpretation that the word

1 Cf. TLL VIII, p. 419 ff.; JANssen, op. cit., p. 136 f.; Hoppenbrouwers, op. cit., passim, esp. p. 207.

- Cf. Odo Caser, Mysterium und Martyrium in den römischen Sacramentarien, JLW 2, 1922, p. 21 ff., esp. p. 29.

- Cf. Brarse, Dictionnaire, p. 592.

- Mohlmerg, 206.

- Cf. Mohrmann, Sondersprache, p. 132.

- Cf. Chr. Mohrmann, Pascha, passio, transitus, Etudes, I², p. $205 \mathrm{ff}$. 
is derived from pati "to suffer". Rather does the word show a fixed and technical sense of "pertaining to the celebration of the Pascha". This latter, in turn, is the name for the feast. Only twice is there any reference in the prayers to what may be regarded as the actual content of the festa paschalia. These are the collect for Fer. VI infra Oct. Pasch.: qui paschale sacramentum in reconciliationis humanae foedere contulisti, 793; and that of Fer. II infra Oct. Pasch.: qui solemnitate paschali, mundo remedia contulisti, 448. Even this latter is quite general and might be found in the secrets and postcommunions - with the exception of the word paschalis, of course - of other feasts as well. So, too, when there are such expressions as: nos per haec mysteria paschalia gratulari, 124 ; festa paschalia egimus, 135; paschalia festa peregimus, 869; we may consider that paschalia has the concrete sense of what in English is termed the Easter Feast. This same holds true for: Sacrificia... paschalibus gaudiis immolamus, 1002; for gaudiis has here the meaning of "festal celebration". Even when there is question of the reception of the "paschal sacrament(s): paschalis perceptio sacramenti, 133; quos sacramentis paschalibus satiasti, 1069-2; and ut paschalibus initiata mysteriis, ad aeternitatis nobis medelam... proficiant, 1131 ; the phrase cannot be taken to mean any more than "the Eucharist received on Easter"; for the effects requested are those which are usually sought from the Eucharist ${ }^{1}$.

Worthy of note is the fact that paschalis does not occur in the ORATIONS to indicate the fast preparatory to Easter. The expression: ieiuniis paschalibus does occur in the Gel. Vetus ${ }^{2}$ for Quinquagesima, and instituta paschalia for Friday of the fifth week of Lent ${ }^{3}$.

PROPHETA, a prophet4.

This Greek loanword in the prayer after the third prophecy in the Easter Vigil has the Biblical meaning of prophet as one who proclaims the word of God, rather than one who foretells the future: sanctorum prophetarum voce manifestasti, 367.

1 Cf. B. Botre, Paschalibus initiata mysteriis, EL 61, 1947, p. $77 \mathrm{ff}$.

2. C. Mohlnerg-L. Eizenhöfer-P. Siffrin, Liber Sacramentorum Romae Aeclesiae Ordinis Anni Circuli. (Gelasianum Vetus), Roma 1960, 94. (N.B. All references to this source will hereafter be made as MohlBerg, Gel. Vetus. Numbers refer to represent those given the prayers in this edition) The Veronense has this collect for the Ember Saturday of Sept., Mohlnerg, 984.

" Mohlmerg, 273; The Veronense has this collect "for the time of draught" in the month of October, Momberg, 1123.

- Cf. Mohrmann, Etudes, I², p. 42, 62, 89, 156. 


\section{Latin new-forms}

\section{BENEDICTIO, a blessing 1 .}

This word has never in the orations the sense which it had frequently in Early Christian Latin; viz., "the praise of God". Nor does it mean the same as "The Chalice of Benediction", 1 Cor. 10, 16. It has rather almost a technical sacral sense. One might almost say that it is the nomen actionis of sanctificare ${ }^{2}$, rather than of benedicere; for it is remarkably like the former in its usage. There are several nuances of meaning noticeable. In the first place it is employed of the "blessing" by which God makes the gifts pleasing to Himself and confers on them the power to effect what they signify. The secret of 8 Nov. expresses this clearly: Benedictio tua... larga descendat: quae et munera nostra... tibi reddat accepta, et nobis sacramentum redemptionis efficiat, 80 ; see also 383,1095 . This "blessing" of God is also invoked upon the rite of Matrimony that it may be supernaturally effective: ut quod nostro ministratur officio tua benedictione potius impleatur, 537 . So also in the dedication of a church or an altar the benedictio of God is visualized as doing more than setting these aside for the exclusive service of God; it makes them supernaturally effective: effunde super hanc orationis domum benedictionem tuam: ut ab omnibus in ea invocantibus nomen tuum, defensionis tuae auxilium sentiatur, 439; altare hoc... caelestis virtutis benedictione sanctifica: ... ut et his sacramentorum virtus, et votorum obtineatur effectus, 755 . Note how well caelestis virtutis is identified with benedictione by means of the genitivus inhaerentiae.

Secondly benedictio stands for the supernatural effect which is produced by the sacred rites: Benedictionem nobis, conferat salutarem sacra semper oblatio: ut quod agit mysterio, virtute perficiat, 81 ; Caelestis doni benedictione percepta, 104; see also 82, 683, 971, 972. Finally, it refers to the help of God in general though not necessarily flowing from the ritual action: Fideles tuos... benedictio desiderata comfirmet, 565 ; perpetuum eis rorem tuae benedictionis infunde, $779 ;$ ut, remissione percepta, in tua semper benedictione laetemur, 900.

CARNALIS, bodily, material ${ }^{3}$.

This word, so frequent in Early Christian writings, both in bonam and in malam partem, has survived in the ORATIONs in only two expressions both in connection with the practice of fasting: escis carnalibus abstinemus, 146, 827; and epularum restrictione carnalium, 1016; ab epulis carnalibus

1 Cf. TLL II,p. 187 ; [L.J. Engels, Observations sur le vocabulaire de Paul Diacre, Nijmegen 1961, p. 56.

C. p. $15 f$.

3 Cf. Mohrmann, Sondersprache, p. 87 ff.; Etudes, I², p. 25, 89, 119. 
abstinere, 850. That carnalis here has the general sense of "material" or "bodily", is substantiated by the fact that abstinere is used elsewhere in the ORATIONs also in a broad sense, so as to include the notion of what we, today, call "fasting" rather than "abstinence". There is no specific reference to "flesh meat" in such phrases as: $a b$ alimentis abstinemus in corpore, 656; or a cibis corporalibus se abstinet, 843.

ConDITIO, a created thing, nature ${ }^{1}$.

This noun was used in Early Christian Latin in the same sense which $\kappa \tau i \sigma \iota s$ and $\kappa \tau i \sigma \mu \alpha$ have in the later books of the OT and sometimes in the NT; viz., "a particular creature". In this concrete sense it was already at an early date replaced by creatura, a word which, though less exact, was in less danger of being confused with condicio. The Christianism, then, remained only as a "mot savant"2. Once in the ORATrons it certainly retains its pristine Christian sense: Deus, qui laboribus hominum etiam de mutis animalibus solatia subrogasti: ... rogamus; ut, sine quibus non alitur humana conditio, nostris facias usibus non perire, 382. In the other two instances of its usage, it means "human nature": $u t$ dignitas conditionis humanae per immoderantiam sauciata, 855; quae sua conditione atteritur, tua clementia reparetur, 684; but it is difficult to determine whether conditio here represents condicio, the classical legal concept with the accent on the weakness of the human being destined to die, or whether the word is really a derivative of condere. Since in both prayers there is mention of renewal in the words reformetur and reparetur, there is in any case no question of the purely pagan notion of the condicio humana. There is rather the truly Christian concept of human nature which is expressed so beautifully in the prayer which now appears in the MR at the mingling of water and wine at the Offertory, but which is found in the Veronense for the feast of Christmas: Deus, qui [in] humanae substantiae dignitatem et mirabiliter condidisti et mirabilius reformasti. ${ }^{3}$

CONFEsSOR, a confessor".

Already in the time of the persecutions, in the meaning of this word, the accent was placed heavily on the act of professing one's Faith, to such an extent that in the course of time confessor underwent a semantic

1 Cf. Teeuwen, op. cit., p. 129; Mohrmann, Sondersprache, p. 173; Etudes, I², p. 44; J. Kamerbeek, La dignite humaine. Esquisse d'une terminographie, Neophilologus 41, 1956, p. $241 \mathrm{ff}$.

2 Cf. Rent Braun, "Deus Christianorum". Recherches sur le vocabulaire doctrinal de Tertullien, Paris 1962, p. $360 \mathrm{ff}$.

3 Mohlberg, 1239.

- Cf. Botte, ALMA 16, 1942, p. 137 ff.; Teeuwen, op. cit., p. 90 ff.; Rheinfelder, Die Sprache 1, 1949, p. 56 ff.; Mohrmann, Sondersprache, p. 173. 
change whereby it came to mean "one who professed the Faith under danger of death, but had not actually died of the tortures". In this connotation it came to be contrasted to the name martyr. Noteworthy, too, is the fact that confessor was a title given to men during their lifetime on earth. When the persecutions were over, this term came to be applied to those bishops especially who defended the Faith against Arianism and other heresies. In the ORATIONs it is applied in all but one instance to bishops: $31,528,540,938-3,1031,1057-17,1172-15$. The one exception is the postcommunion for the feast of St. Jerome, 969.

CREATURA, a created thing, creature ${ }^{1}$.

This word, which as early as St. Cyprian, largely replaced the Christianism conditio $^{2}$, occurs once in the sense in which it became usual in Christian Latin, namely, "created things" in general: in his... creaturis... munera dicanda constitui, 487 . It expresses the beautiful idea of the "new creation" which is the effect of the sacraments of initiation administered during the Paschal Vigil, and which is the effect of every increase of grace which comes with the participation in the Eucharist: sacramenti tui veneranda perceptio in novam transferat creaturam, 4.

GLORIFICATIO, glorification ${ }^{3}$.

This noun as applied to the feast of Ss. John and Paul could be interpreted in two ways. It may mean their triumph over death, and as such denote the share which God gives them in the glorificatio of Christ, i.e. the "liberation of His humanity from death and mortality... the manifestation of His divine greatness breaking through the weakness of the flesh"4. This glorificatio of the saints is the cause of joy to the Church: quae (laetitia) de beatorum Joannis et Pauli glorificatione procedit, 943. But there is also a second element, namely, glorificatio may be the nomen actionis of glorificare in the sense of "to honor, to extol". As the official act of the liturgical celebration, then, glorificatio would be very close in meaning to the word "feast".

INCARNARI, to be made man ${ }^{5}$.

This verb is a technical term for the act of assuming a human nature by the Second Person of the Bl. Trinity. It occurs but once; viz., in the

1 Cf. TLL IV, p. 1115; Teeuwen, op. cit., p. 129.

- Gf. René Braun, op. cit., p. 364, $370 \mathrm{ff}$.

- Cf. TLL VI, p. 2088; A. J. Vermeulen, The Semantic Development of Gloria in EarlyChristian Latin, Nijmegen 1956, p. 194 ff.; M. Steinhermer, Die Doxa tou Theou in der römischen Liturgie, München 1951, p. 38, $47 \mathrm{ff}$.

- Cf. Vermeulen, op. cit., p. 195.

- Cf. TLL VII, p. 846 f.; Mohrmann, Sondersprache, p. 118; Etudes, I², p. 90. 
collect for the second Christmas Mass: qui nova incarnati Verbi tui luce perfundimur, 176. The noun incarnatio also appears but once in the ORATIONs: Christi Filii tui incarnationem cognovimus, 575.

INHABITATIO, the act of dwelling 1 .

It is used of the special presence of God in a consecrated church: templum hoc potentia tuae inhabitationis illustra, 380.

JUSTIFICARE, to make just or righteous; to justify².

This Latin new-form for the LXX and NT idea of $\delta \iota$ caıviv has, for the most part, a much deeper content than the forensic "to declare innocent". St. Augustine says: Christus iustificat, homo non iustificat... quid est iustificare? iustum facere. Like other words in -ficare, it is rare in the ORATIONs; but it does have the meaning of "to make just" in the prayer for Sabb. Sanct. p. prophetiam IV : excita in omnem justificatarum gentium... potentiam tuam, 205, and in the collect, Pro tentatis et tribulatis: Deus, qui justificas impium, 381 . In the absolutio super tumulum, since the whole tone is that of a court process, we may be safe in concluding that the forensic idea predominates in: quia nullus apud te justificabitur homo, nisi per te omnium peccatorum ei tribuatur remissio, 721.

MORTIFICARE, to deaden ${ }^{3}$.

Though this word was from earliest times used in Christian Latin for the mortification of the flesh, it appears only once in the ORATIONs - and then not in Lent when one would expect it, but for the feast of the Holy Innocents: omnia in nobis vitiorum mala mortifica, 213.

QUADRAGESIMALIS, pertaining to the observance of the forty days of Lent ${ }^{4}$.

This adjective is a Late Latin formation from quadragesima, which

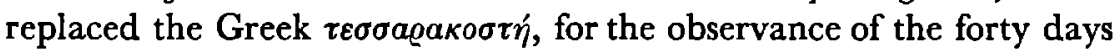
preparation for Easter. It occurs in the following expressions: jejunium quadragesimale, 143; observatio quadragesimalss, 327, 1012; Sacrificium quadragesimalis initii, 1016. There is at least some evidence that this word replaced the older expression paschalis observantia for the Gel. Vetus and other older Mss until the Lateran Missal (dating from XI-XII century) have this latter expression. The word, thus, lays stress on the fact that the preparation lasts 40 days.

1 Cf. TLL VII, p. 1584; A. J. KINNIREY, The Late Latin Vocabulary of of the Dialogues of St. Gregory the Great, Washington, D.C. 1935, p. 4.

2 Cf. Blaise, Dictionnaite, p. 480; Bartelink, op. cit., p. 101.

3 Cf. Mohrmann, Sondersprache, p. 193.

- Cf. Mohrmann, Etudes, $\mathrm{I}^{2}$, p. 43; A. A. R. Bastiaensen, Observations sur le vocabulaire liturgique dans l'Ilinéraire d'Égérre, Nijmegen 1962, p. 133 ff. 
REGENERATIO, rebirth'.

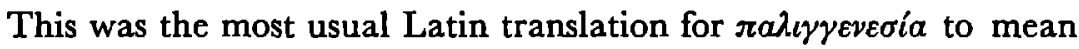
the "rebirth of Baptism"2. This concrete sense is evident in the prayer after the second prophecy in the Easter Vigil: id in salutem gentium per aquam regenerationis operaris, 211 . The second time that it occurs it is influenced by stylistic considerations; for it is obviously used to be the counterpart of generatio in the postcommunion for the Nativity of St. John Baptist: Sumat Ecclesia... Joannis Baptistae generatione laetitiam: per quem suae regenerationis cognovit auctorem, 1074. Here it means the renewal of man which, according to Paul, is part of the new arrangement of the whole creation in Christ ${ }^{3}$.

REMISSIO, forgiveness of sins ${ }^{4}$.

This Latin new-form occurs six times with an objective genitive: remissio peccatorum, 217, 241, 567, 721; remissionemque eorum, 752 ; remissio delictorum, 923. Its use without such accompanying genitive, however, in the other three instances shows to what a degree the word had become a technical term: Peccatis tua remissione deletis, 205; remissione percepta, 900; maculae... remissionis tuae misericordia deleantur, 1117.

SALUTARE, Salvation ${ }^{5}$.

This noun which was so frequent in Early Christian literature appears only three times in the ORATIONs: et salutare tuum in nobis mirabiliter operetur, 469; ut illius salutaris capiamus effectum, 940; Salutaris tui... munere satiati, 1026. It may be its vulgar origin which caused this word to be avoided, while its synonym, salus appears at least 42 times $^{6}$. However, Mohrmann states that salutare "had in the course of time climbed upward and had become fuller of sacred feeling than the cognate Christianism salus". This statement is substantiated by the fact that St. Jerome retained the former in his Hebrew Psalter?

SALVARE, to give supernatural salvation ${ }^{8}$.

1 Cf. Teeuwen, op. cit., p. 122; A. von Harnack, Die Terminologie der Wiedergeburt und verwandter Erlebnisse in der ältesten Kirche, Leipzig 1918, p. $106 \mathrm{ff}$.

Cf. Ysebaert, op. cit., p. 136, 146.

Cf. Gal. 6, 15; 2 Cor. 5, 17; Eph. 2, 10.

- Cf. Mohrmann, Sondersprache, p. 143.

- Cf. H. RöNsch, Itala und Vulgata. Das Sprachidiom der urchristlichen Itala und der katholischen Vulgata unter Berücksichtigung der römischen Volkssprache ${ }^{2}$, Marburg 1875, p. 104; Mohrmann, Sondersprache, 145; Etudes, II, p. 123 f.

- Cf. p. $55 f$.

7 Gf. Chr. Mohrmann, The New Latin Psalter. Its Diction and Style, Eludes, II, $109 \mathrm{ff}$., reference to p. 124.

- Cf. W. Matzkow, De vocabulis quibusdam Italae et Vulgatae christianis, Berlin 1933, 
This neologism, which is the equivalent in Latin of the LXX and NT $\sigma \omega \zeta \xi c \nu$, has the soteriological meaning "to give supernatural salvation to the soul". As such, it is an essentially Christian concept, and fits into the system - salus, salvus, salvator ${ }^{1}$. It has the full Biblical content in the solemn prayer for heretics and schismatics: Deus, qui salvas omnes, et neminem vis perire, 799. It is limited specifically to freedom from sins in the collect for Dom. I Adv. : ut ab imminentibus peccatorum nostrorum periculis, te mereamur protegente eripi, te liberante salvari, 546 . It is employed in an interesting word play in: salva nos per indulgentiam, quos dignatus es salvare per gratiam, 472, where the first saloare means "convert from personal sins" and the second means the salvation brought in Baptism. As is to be expected, most of the instances refer to the saving power of the sacred action of the Eucharist: Sacramentorum tuorum... communio sumpta nos salvet, 1000; Sacrificia... propensius ista nos salvent, 1003; Sentiamus... tui perceptione sacramenti, subsidium mentis et corporis: ut in utroque salvati, caelestis remedii plenitudine gloriemur, 1063 ; see also 82, 590, 836. To be noted is the fact that in the orations there is no evidence of that secondary development of salvare, whereby it took on a medical connotation, except, perhaps, through suggestion, by reason of its being used in conjunction with other medical terms.

SALVATIO, salvation.

This Early Christian formation which appears first in Hilary and Ambrose $^{2}$ is another example of the application of a broad Christian concept specifically to the action of the Eucharist: sacramenta nos... ad perpetuae ducant salvationis effectum, 924; sic nobis effectum... tuae salvationis impendant, 1064. The genitive of definition makes it clear that salvatio might be called, in our more abstract terminology, "sacramental grace". The oft-recurring rhetorical juxtaposition of the external rite to the inner effect illustrates this also in: ut quod debitae servitutis celebramus officio, salvationis tuae sentiamus augmentum, 1022; and quae temporali celebramus actione, perpetua salvatione capiamus, 1056. Note too: Sit nobis... sacramenti tui certa salvatio, 1066. Although perpetua modifies salvatio: quae (oblatio) nos... perpetua salvatione confirmet, 717 (see also 924, 1056); only once does this noun refer explicitly to the reward of the just in

p. 18 ff.; Bonffatius Fischer, Praeceptis salutaribus moniti, ALW 1, 1950, p. 124 ff., esp. p. 126; Chr. Mohruann, Les emprunts grecs dans la latinite chretienne, VC 4, 1950, p. 193 ff., esp. p. $201 \mathrm{ff}$.

1 Cf. Mohrmann, Études, I², p. 25, 91, 119; P. C. J. Eijkenboom, Het Christus-medicusmotief in de preken van Sint Augustinus, Assen 1960, p. $54 \mathrm{ff}$.

2 Cf. M. M. Mueller, The Vocabulary of Pope St. Leo the Great, Washington, D.C. 1943, p. B, 238. 
heaven: et a contagiis mortalitatis exutam, in aeternae salvationis partem restitue, 929 .

SALVATOR, Savior.

This Christian new-form, which only at the end of the fourth century was adopted definitively into the literary language of the Christians ${ }^{1}$, refers usually to Christ: Salvatorem nostrum carnem sumere, et crucem subire fecisti, 783, natus hodie Salvator, 858; Salvatorem mundi... cecinit, 1143 . When it is used as an address, it refers to the Father: Praesta nobis, aeterne Salvator, 835. This need not indicate that it would not be so used of the Son; but the early prayers are simply not addressed to the Second Person of the Trinity. See salutaris, p. 56.

SANCTIFICARE, to make holy.

This is one of the few verbs in -ficare which, despite its vulgar origin, has maintained itself in the lofty diction of the ORATrons'2. It was the

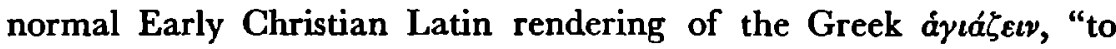
make holy"3. This is its meaning pure and simple in the solemn prayer for all orders in the Church: Deus, cujus spiritu totum corpus Ecclesiae sanctificatur et regitur, 758.

For the most part though, this word is used in relation to the gifts - it expresses either God's action upon them or His action on the faithful in and through these ritual offerings. Thus we have: plebis tuae dona sanctifica, 57; Spiritus tuus Sanctus... populi tui dona sanctificet, 198; Munera... oblata sanctifica, $689,702,723 ;$ tua... dona sanctifica, 1125 . That sanctificare is understood as having a kind of consecratory effect, rendering the gifts holy in such a way that they are capable of effecting what they signify, is evidenced by the wording of such a secret as that of Dom. VII. p. Pent: accipe sacrificium a devotis tibi famulis, et pari benedictione, sicut munera Abel, sanctifica; ut, quod singuli obtulerunt ad majestatis tuae honorem cunctis

1 Lactantius has: Jesus, qui latine dicitur Salutaris, sive Salvator, quia cunctis gentibus salutifer venit (Inst. 4, 12,6); and Augustine: Christus inquit Jesus, id est Christus salvator. Hoc est enim latine Jesus. Nec quaerant grammatici quam sit Latinum, sed Christiani quam verum. Salus enim latinum nomen est. Salvare et salvator non fuerunt haec latina antequam veniret salvator : quando ad latinos venit, et haec latina fecit (Sermo 299, 6). Cf. MohrmanN, VC 4, 1950, p. 205; Le latin commun et le latin des chrétiens, VC 1, 1947, p. 1 ff., esp. p. 4 ff.; Les eléments vulgaires du latin des chretiens, VC 2, 1948, p. 89 ff.; 163 ff., esp. p. 171; P. De Labriolle, Salvator, Mélanges en hommage à la mémoire de Fr. Martroye, Paris 1940, p. 59 ff., esp. p. 68 f.

2 Verbs in -ficare are: amplificare $(2 \times)$, justificare $(3 \times)$, laetificare $(17 \times)$, magnificare $(1 \times)$, sanctificare $(25 \times)$, vivificare $(4 x)$, significare $(2 x)$, mortificare $(1 \times)$, purificare $(28 \times)$, sacrificare $(1 \times)$.

af. Blaise, Dictionnaire, p. 737; Mohrmann, Sondersprache, p. 146; Etudes, I², p. 25, 58. 
proficiat ad salutem, 383. The petition is, thus, that once the sacrificium has been "sanctified", it may produce the effect of salutem. Even in such cases as: Oblata... munera... sanctifica: nosque a peccatorum... maculis emunda, 723; and haec dona sanctifica: et hostiae spiritalis oblatione suscepta, nosmetipsos tibi perfice munus aeternum, 907, the paratactic construction does not nullify the relation of cause and effect between the two members.

When this verb is applied to the effectiveness of the sacred action, it has a rich sacramental content; for in these prayers we do not ask God to sanctify us directly, but that $\mathrm{He}$ do it through the sacred gifts or rites, or, perhaps better stated, that the gifts or rites produce a sanctifying effect in virtue of the divine power given them. Praesta... ut, quod de sancto altari tuo accepimus... sanctificet animas nostras, 871; Sanctificati divino mysterio, 1041; Sanctificet nos... mensa caelestis, 1048; ut haec sacrosancta mysteria... nos... sanctificent, 1127 . See also 726,1127 . The word is also applied to the sacrament of Baptism: ut fidei ipsius sitis, baptismatis mysterio animam, corpusque sanctificet, 803. The Lenten fast, too, by reason of the "sanctifying" power given it by God, becomes an outward sign productive of an inner supernatural effect: Praesentibus sacrificiis... jejunia nostra sanctifica: ut, quod observantia nostra profitetur extrinsecus, interius operetur, 832; see also 1040, 1046. That in the postcommunion for the dedication of an altar, sanctificare means more than "to set aside for religious rites" is evident from the words of the text: altare hoc nomini tuo dedicatum, caelestis virtutis benedictione sanctifica: ... ut, et hic sacramentorum virtus, et votorum obtineatur effectus, 755 . The word is already definitely a cliche in the two prayers for the blessing of ashes and of candles: mittere digneris sanctum Angelum de caelis, qui benedicat, et sanctificet hos cineres, 769; benedicere et sanctificare... digneris, 781. Nor does it have a sacramental character in: Deus, qui pretioso sanguine, vivificae Crucis vexillum sanctificare voluisti, 454, and per quem Crucis est sanctificatum vexillum, 657; where it means "to make holy" in the sense of "to make an object of veneration".

SANCTIFICATIO, sanctification'.

It seems safe to say that in all six instances of its appearance this word

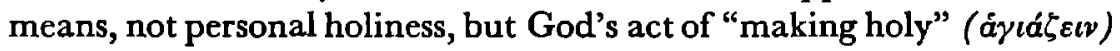
This is quite evident in: ut, quod mea voce depromitur, tua sanctificatione firmetur, 743; Sanctificationem tuam nobis, ... his mysteriis operare placatus, 1044; quae (hostiae) et sanctificationem nobis clementer operetur, 1095; Sanctificationibus tuis... et vitia nostra curentur, et remedia nobis aeterna proveniant, 1045. The words of the first prayer on Good Friday: sicut imaginem terrenae naturae necessitate portavimus, ita imaginem caelestis gratiae

1 Cf. preceding note. 
sanctificatione portemus, 1183, may seem at first sight to mean "that we may bear the image of heavenly grace by our personal holiness". When one considers the antithesis: imaginem terrenae naturae - imaginem caelestis gratiae and necessitate - sanctificatione, it becomes clear that the natural (now actually fallen) state of man is here juxtaposed to his condition as redeemed by the sanctifying grace of God. The secret of Dom. III p. Pent. has: et saluti credentium perpetua sanctificatione sumenda concede, 979. Brou sees in sanctificatio in this context the disposition of the faithful: "dans un état constant de saintes dispositions (nous dirions maintenant: soient toujours reçus en état de grâce)" 1 . This does not seem to us to be the best interpretation, and this for the following reasons: (a) In all the other instances, sanctificatio refers to God's sanctifying action and not to man's holy dispositions. (b) The word sanctificatio is applied expressly to the action of the sacred rites in other prayers, e.g., 1044, 1045. (c) Given the fact that frequently the ORATIONs are characterized by a certain abundance of expression, where synonyms abound for the sake of rhythm or alliteration or simply to add a solemn character to the prayers ${ }^{2}$, the presence of salus and sanctificatio in the same phrase causes no problem. Salus here represents man's redeemed condition while sanctificatio is God's sanctifying action again and again (perpetua) renewed in the sacred rites.

SANCTIFICATOR, sanctifier ${ }^{3}$.

This Early Christian nomen auctoris was applied to God, e.g., et sacrifico laudem sanctificatori meo $^{4}$, and specifically to the Holy Spirit. It occurs but once, namely, for the feast of St. James: Esto... plebi tuae sanctificator et custos, 524 .

SPIRTT(U)ALIS, spiritual5.

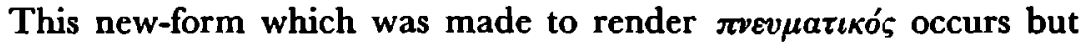
7 times in the orations. The term spiritales nequitiae, 3,117 is doubtlessly inspired by the Pauline text of Eph. 6, 12, where the apostle speaks of the devils as spiritalia nequitiae. In the other instances it is used in bonam

1 Lours Brou, Les oraisons des dimanches apres la Pentecóte. Commentaire liturgique, Bruges 1959, p. 22.

2 Cf. M. G. Hasssly, Rhetoric in the Sunday Collects of the Roman Missal, Cleveland, Ohio 1938, passim; Hans Rheinfelder, Zum Stil der Lateinischen Orationen, JLW 11, 1931, p. 20 ff.; J. Cochez, La structure rhythmique des oraisons, Louvain 1928; P. SALmon, Les protocoles des oraisons du Missel Romain, EL 45, 1931, p. $140 \mathrm{ff}$.

Cf. Blause, Dictionnaite, p. 735.

- Aug., Conf. 10, 34, 53.

- Cf. Mohrmann, Sondersprache, p. 154 ff.; Etudes, I², p. 25, 89; Engets, op. cit., p. 61, note 6 . 
partem of "spiritual" as set over against the material: ut, quod Ecclesiae tuae corporalibus proficit spatiis, spiritualibus amplificetur, 321 ; Sacramenta... et spiritualibus ${ }^{1}$ nos repleant alimentis, et corporalibus tueantur auxiliis, 991. Then there are: Repleti cibo spiritualis alimoniae, 970; da populis tuis spiritualium gratiam gaudiorum, 436. The phrase: hostiae spiritalis oblatione suscepta, 907 of the secret for Fer. II infra Oct. Pent. recalls the words of

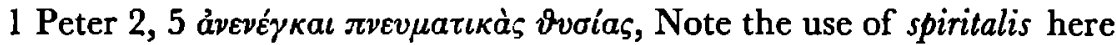
and not the archaic Christianism rationabilis. This latter often had in earliest Christian times the sense of "spiritual"; but it gradually underwent semantic change so that it came to mean "reasonable, conformed to the essence of a thing" and was replaced in its earlier meaning by spiritalis almost entrrely ${ }^{2}$. However, we find rationabilis in its older sense of "spiritual" in the collect for Dom. VI p. Epiph.: ut semper rationabilia meditantes, quae tibi sunt placita, et dictis exsequamur, et factis, 875 . The adverb, spirit (u)aliter, occurs also but once, and that in the juxtaposition of the external rite to the inner effect thereof: quae temporaliter agimus, spiritualiter consequamur, 718.

unigenitus, the Only-begotten Son of God, Jesus Christ ${ }^{3}$.

This Christian new-form, Braun maintains, issued from the doctrinal teaching of the Early Church, which found it necessary to forge a new term in order to render with theological precision the idea contained

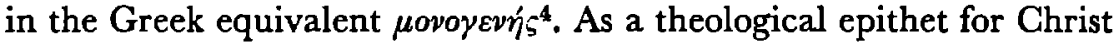
as the Son of God, it seems to have been adopted early into Christian texts. It occurs some 20 times in the orations. Sometimes it is used as an adjective: expectata unigeniti Filii tui nova nativitate liberemur, 139; see also $169,192,454,646,697,765,868$. This has become a fixed expression for every time it is used, it is in exactly the same order: unigeniti Filii tui. When it is used as a noun, it displays the same tendency; thus we have Unigenitus tuus, 131, 136, 350, 351, 410, 450, 452, 689, 723, 781, 1167. Though the absolute use of this word might indicate a later semantic development, whereby it became a technical term to such an extent that alone, without the accompanying Filius, it was sufficient to indicate the "Only-begotten Son of God", there is no indication that the prayers

1 The spelling with - $u$ - is less authentic. It did not appear until the 11 th century. The older form fits better into the rhythmical pattern also.

${ }^{2}$ Cf. Odo Casel, Oblatio rationabilis, Tubinger theol. Quartalschr. 99, 1917, p. 429 ff,; Die Moyexj Ovoia der antiken Mystik in christlich-liturgescher Undeutung, JLW 4, 1924, p. $37 \mathrm{ff}$; Ein orientalisches Kultwort in abendlandischer Umschmelzung, JLW 11, 1931,

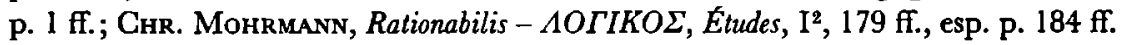

a Cf. Blaise, Dictionnaire, p. 857; Bartelink, op. ctt., p. 133.

4 Cf. René Braun, op. cit., p. 248 ff. 
containing the nominal form are from a later date than the others.

\section{Semantics}

ADOPTIO, the condition of being raised to the state of a child of God'.

While the Vulgate translates the Pauline expression $\pi v \varepsilon v v a$ vioigria ${ }^{2}$ with characteristic literalness, as spiritum adoptionis fliorum, the ORATIONs use adoptio unmodified by the genitive. The term is employed by Paul as including the whole mystery of man's supernatural adoption. In the ORATIONS it maintains this meaning, and the expression spiritum adoptionis in the collect for the Easter vigil: conserva... adoptionis spiritum, quem dedisti, 346; and in the second prayer at the blessing of the font: spiritum adoptionis emitte, 754 . In the solemn prayer for the catechumens: ut renati fonte baptismatis, adoptionis tuae filiis aggregentur, 777, Baptism is mentioned explicitly as the means whereby the adoption takes place.

ADUNARE, to gather together'.

Qui diversitatem gentium in confessione tui nominis adunasti, 326. The meaning of adunare here is that which is familiar in the Bible and the Fathers, namely, the gathering together of all nations to form part of the people of God".

ADVENTUs, the coming of Christ ${ }^{5}$.

This noun which was early the Latin equivalent for éruqáveıa and

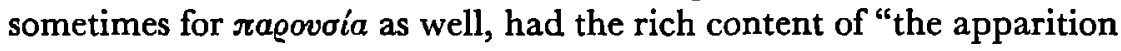
of Christ" and it had reference to His first coming as well as to His coming in glory at the end of time. It seems that both concepts are included, too, in this word in the ORATIONs, at least the term is left very general: ut per ejus adoentum, purificatis tibi mentibus servire mereamur, 542; ut adventus tui consolationibus subleventur, 561; unigeniti Filii tui adventu laetifica, 646. It is perhaps better to say that the word has the same content here as ė $\pi \iota p a ́ v \varepsilon \iota a$ in its early connotation as "the apparition of God and the demonstration of His activity, as well".

Altare, the Christian altar ${ }^{6}$.

This noun was normally used in the plural by pagan authors, while

1 Cf. TLL I, p. 806; von Harnack, Terminologie der Wiedergeburt, p. 103 f.; Ysebaert, op. cit., p. $137 \mathrm{ff}, 376,378$.

2 Rom. 8, 15 and 23; Eph. 1, 5.

3 Cf. TLL I, p. 888 f.

- Cf. Botte-Mohrmann, op. cit., p. 75, note 12.

5 Cf. TLL 1, 837; Chr. Mohrmann, Epiphania, Etudes, I'2, p. $245 \mathrm{ff}$.

- Cf. TLL I, p. 1725 ff.; Mohrmann, Études, II, p. 20; J. Braun, Der christliche Altar in seiner geschichtlichen Entwicklung, I, Munchen 1924, passim. 
Christians used preferably the singular form to denote their altar of sacrifice. Thus, it may, at first sight seem surprising that in the ORATIONs it occurs three times in the singular and seven times in the plural. This would indicate that the fear of pagan connotations was no longer felt at the time when these prayers were composed. Examples which confirm this supposition are the collect and secret, Pro seipso Sacerdote: dignum sacris altaribus fac ministrum 1 , 743 ; me... sacris altaribus astare voluisti, 788; as well as, the secret for Fer. VI p. Dom. I Pass. : ut digne tuis servire... altaribus mereamur; et eorum perpetua participatione salvari, 836. In all three of these, altaria, even though it is plural, refers clearly to the one Christian altar. There may be another factor which has played a contributing role in the use of the plural form in secret prayers. An unknown Roman cleric in the year 515 included in his account of the life of Pope St. Sylvester, the detail that Emperor Constantine had given the Pope altaria septem ex argento purissimo... ${ }^{2}$. Th. Klauser has developed a rather wellgrounded theory that these seven altars were "side tables" destined to receive the gifts of the faithful, and thus to facilitate the offertory procession ${ }^{3}$. Thus, the plural form could represent these side tables which were, certainly on feast days at least, piled high with gifts. Mark the following phrases from secrets: Tua... muneribus altaria cumulamus, 1143; Sacris altaribus... hostias superpositas, 1019 ; Hostias... quas sacris altaribus exhibemus, 619 ; munera altaribus tuis... proposita, 650. Still it is difficult to conclude from that one account, that the practice of using such "side altars" was general. There can be no question that the use of the singular represents the specifically Christian usage of the word. Thus it occurs in the postcommunion for St. Luke: ut quod de sancto altari tuo accepimus, 871 ; and in the secret and postcommunion of the Mass for the dedication of the altar: Descendat... Spiritus... super hoc altare, 198; altare hoc nomini tuo dedicatum, 755.

ANTISTEs, a person in charge, bishop 4 .

This indigenous Latin word seems never to have become very prevalent in the Roman liturgy. It occurs only once in the Veronense and but once also in the ORATIONs: et electum nobis Antistitem tua pietate conserva, $757^{5}$. It was apparently introduced late into Christian literature. The

1 This collect appears in the Veronense under the heading In natale episcoporum, Mohlaerg, 964.

2 Cf. L. Duchesne, Le Liber pontificalis, (I-II, Paris 1886-1892), I, p. 172.

a Cf. Th. KLAuser, Die konstantinischen Altäre der Lateranbasilika, Römische Quartalschrift 43, 1935, p. $179 \mathrm{ff}$.

4 Cf. TLL II, p. 185; Mueller, op. cit., p. 85.

B It occurs in the invitation and in the oratio $2 a$ for Good Friday. In 432 it is a later addition, and 299 falls entirely outside the scope of our study. 
TLL mentions Lucifer, Damasus, Aug., Sidon., Vict. Vit., etc. An interesting historical observation can be made from the text of 757 as it stands in the Gel. Vetus, where in the invitation to the solemn prayer for the Pope on Good Friday we read: Oremus et pro famulo dei papa nostro sedis apostolicae Illo et pro antistite nostro Illo; and the oration proper has: electos a te nobis antestites tua pietate conserva ${ }^{1}$. Thus, Pope and local bishop were included under one heading in the same prayer; whereas today the Pope alone is prayed for in the first prayer, while the local bishop receives no special mention except to be included in the prayer for all the orders of the Church. This may point to the great influence of the Gregorianum which was a papal sacramentary and would naturally have no special mention of one local bishop other than the Pope, or it may indicate a shift in emphasis in regard to the position of the Pope.

AETERNUs, everlasting, supernatural.

This adjective which, in pagan cultic language was apparently applied only to the emperors and the Syrian Gods and their Roman substitutes, was used very frequently by Christian writers for God and divine things ${ }^{2}$. In the ORATIONs it has a very wide application. Sometimes it refers clearly to the life after death: a praesenti liberari tristitia, et aeterna perfrui laetitia, 122; da nobis in aeterna beatitudine de eorum societate gaudere, 403 ; et post hujus temporis decursum, ad aeternam perveniat hereditatem, 578. Again it is the characteristic of the inner effect produced by the sacred rites: Guberna... temporalibus alimentis: quos dignaris aeternis informare mysteriis, 577 ; et quem aeternis dignatus es renovare mysteriis, a temporalibus culpis dignanter absolve, 985 ; ut quod temporaliter gerimus, aeternis gaudiis consequamur, 1075. Then there are the numerous instances where it modifies gaudia, laetitia, salus, praemia, and the like. In all the instances mentioned - even those referring to the life after death - the idea of "never ending" is far from adequate to express what aeternus indicates. Even as in the Johannine phrase: Haec est autem vita aeterna: Ut cognoscant te, solum Deum verum, et quem missisti, Jesum Christum (Jn. 17, 3), aeterna vita means far more than merely a life which will never end. So also do expressions like: ad gaudia aeterna pervenire mereamur, 411 , indicate not so much simply "unending joy", but a joy which is supernatural and thus partakes of the very "eternity of God"3. Most of the instances are ambiguous, i.e., it is impossible to distinguish from the context of the prayer whether aeternus refers to the life hereafter or to the supernatural

1 Mohlderg, 402, 403.

2 Cf. TLL I, p. $1144 \mathrm{ff}$.

3 Cf. Chr. Mohrmann, Locus refrigerii lucis et pacis, QLP 3, 1958, p. 196 ff., esp. p. 201. 
life of the Christian here and now. Or perhaps better, one should see in this apparent ambiguity the finest evidence for the fact that there is no essential difference between the two. The aeterna vita, salus, or even praemia begun in Baptism, is constantly increased through the sacred functions of the liturgy and reaches its full fruition in eternity. Thus, for example, in the prayer: ut et temporalis vitae tribuas pace gaudere; et aeternae reperire subsidium, 527 , aeternae (vitae) is obviously the supernatural life of the Christian as such. And so examples could be multiplied. Noteworthy is the fact that aeternus is used only once for punishments; 145. Once it is used as a noun in the sense of "eternity": ut eis proficiat in aeternum, 51. Three times it is used as an attribute of God: Pastor aeterne, 576b; salus aeterna, 804; aeternae Trinitatis, 774.

APPARERE, to reveal in human flesh ${ }^{\mathbf{1}}$.

Deus, cujus Unigenitus in substantia nostrae carnis apparuit, 221.

APPARTIO, revelation of God in human form.

Hostias tibi... pro nati Filii tui apparitione deferimus, 625 . The fact that the collect above, 221, and this secret, 625, were already used in the $\mathrm{Gel}$. Vetus for the feast of Epiphany has led to much discussion as to whether the words apparere and apparitio are terms typical of the feast of Epiphany or whether they refer to the Incarnation primarily. Dom H. Frank has maintained that they referred first to the Nativity and only later were transferred to Epiphany ${ }^{2}$. Professor Mohrmann has shown that apparitio as applied to Epiphany is typically Spanish and Gallican ${ }^{3}$. In any case, both words refer in the ORATIONs to the revelation of God in human form.

ASGENDERE, to go with body and soul to heaven.

ad caelos ascendisse credimus, 136. See below.

Ascensio, The Ascension of Christ into Heaven ${ }^{4}$.

Like the verb, this noun occurs but once in the ORATIONs: quae pro Filii tui gloriosa Ascensione deferimus, 1110. It is interesting to note that neither the phrase, assumptus est in caelum (Mk. 16, 9; and Acts 1, 19), nor, ferebatur in caelum (Lk. 24, 5), but the word of Jn. 20, 17, ascendo ad Patrem meum, has given rise to the technical name for the mystery

1 Cf. TLL II, p. 262; Mohrmann, Etudes, I', p. 264 r.

2 Cf. H. Frank, Frühgeschichte und Ursprung des römischen Weihnachtsfestes, ALW 2, 1952, p. 1 ff., esp. p. 11 ff.; Hodic caelesti sponso iuncta est ecclesia, Vom christlichen Mysterium. Festschrift Odo Casel, Dusseldorf 1951, p. $192 \mathrm{ff}$.

3 Cf. Mohrmann, Etudes, I', p. 265.

4 Bastiaensen, op. cit., $130 \mathrm{ff}$., discusses the historical development of the name quadragesimae for Ascension and gives further bibliography on the question. 
which in the Latin liturgy is known as the Ascension. We have here an example of the process whereby a noun tends to become a technical term sooner than does a verb, because no such explanatory phrase was deemed necessary with the former. Furthermore, the employment of the adjective gloriosus in place of an objective genitive lends the noun ascensio that rich connotation which it had for the Fathers, namely, the final entering of Christ into His glory or the full sharing of the humanity in the glory of the divinity.

BEATTTUDo, the state of blessedness in Heaven.

This is one of the synonyms used in the ORATIONs to express the state of blessedness in Heaven". It is a term "qui grâce à Saint Augustin surtout, était revêtu de toute la riche conception eschatologique du christianisme, mais qui avait aussi quelque relation avec le terminologie de la philosophie stoïcienne"2. It is used especially in prayers for the departed: da famulis... quietis beatitudinem, 223, 233; ad perpetuae beatitudinis consortium pervenire, 465 ; in congregatione justorum aeternae beatitudinis jubeas esse consortem, 851 ; lucis perpetuae... recipiant beatitudinem, 877 . There is mention of: aeternae beatitudinis praemia, 261, 874, on the feast of St. Gregory the Great, and on Fer. IV Quar. Temp. Adv.; the request that our friends may: gloriam aeternae beatitudinis acquirant, 683 , in the secret, pro amicis; and that the people of God may: sempiternam beatitudinem consequantur, 1126, on Fer. Vinfra Oct. Pasch. It is worthy of remark that so many synonyms for "the state of eschatological happines" appear together with beatitudo - quies, lux, gloria, praemia, justorum consors. All of these are Early Christian terms, and their employment may indicate that beatitudo was not a technical term, sufficient by itself to convey adequately the idea of the joy of Heaven. But stylistic considerations may also have played a role here. Such pleonastic expressions are by no means infrequent in these prayers.

CARo, human nature, the flesh, the body ${ }^{3}$.

This word, so frequent in Early Christian literature, both in bonam and in malam partem, shows the same differences of meaning in the ORATIONs as characterized its early usage. It occurs five times in reference to the Word-made-flesh. The two technical expressions for the assumption of a human nature by the Son of God, carnem sumere and carnem suscipere ${ }^{4}$ each occur once: Salvatorem... carnem sumere, 783;

1 Cf. Vermeulen, op. cit., p. 218.

2 Cf. Chr. Mohrmann, Notes sur le latin liturgique, Etudes, II, p. 93 ff., esp. p. 104.

8 Cf. Mohrmann, Sondersprache, p. 88 f.

- G. p. 88. 
Verbum... carnem suscipere voluisti, 320 . We find also the phrases: $U t$ nos Unigeniti tui nova per camem Nativitas liberet, 131; Unigenitus in substantia nostrae carnis apparuit, 221 ; Filius... cum nostrae carnis substantia, 765 . Note that in these last two instances, though caro actually means the human nature assumed by Christ, still it is modified by nostra in order to emphasize His oneness with us.

As we have seen when we treated the word carnalis ${ }^{1}$, caro, too, is used in connection with the fasting practice: ut castigatio carnis, assumpta, 181; familia... affligendo carnem, ab alimentis abstinet, 857; quae (familia) se carnis maceratione castigat, 976 . It is difficult to determine whether caro has in these three instances the meaning "sinful flesh", thus sinful habits, or whether it has simply the neutral meaning, "body". However, the context of the prayers seems to add weight to the former assumption. Finally, there are the instances where caro unmistakably means simply "body": refloreat cor et caro nostra vigore pudicitiae, 484; ut femineo corpori de virili dares carne principium, 434; adhuc in carne retinet, 802.

claritas, the light element in the glory of God.

From earliest Christian times this noun was used to depict the manifestation of God's glory with the stress on the light element

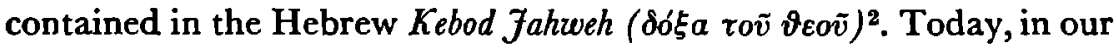
somewhat more abstract manner of expression we might say, "man receives a share in the glory of God through the supernatural illumination of grace"3; but the collect for the vigil of Pentecost employs more concrete terminology: Praesta... ut claritatis tuae super nos splendor effulgeat, 854 , to give utterance to the desire for a renewed share in the divinity. The prayer over the people for Fer. IV Quat. Temp. Quadr. expresses the same idea: Mentes nostras... lumine tuae claritatis illustra, 678. Note how the Biblical content of claritas as the light element in the Kebod Jahweh is further enhanced by its use in a genitivus inhaerentiae construction with another word indicating light. And when in the collect for the first Mass of Christmas we find: Deus, qui hanc sacratissimam noctem veri luminis fecisti illustratione clarescere, 347 , we cannot fail to see that clarescere partakes of the meaning of claritas and means "to partake in the brightness of God". Three times this noun is used to indicate the "eschatological share in the glory of God" which will be the lot of the faithful after death: da... refrigerii sedem, quietis beatitudinem, et luminis

1 C. p. 9 r.

2 Cf. Chr. Mohromann, Note sur doxa, Etudes, $\mathrm{I}^{2}$, p. $278 \mathrm{ff}$, where is included important bibliography; Vermeulen, op. cit., p. 25 f., 89, 112, 191 ff.; Steinheimer, op. cit., p. $27 \mathrm{ff}$.

s Cr. Vermeulen, op. cit., p. 149 fi. 
claritatem, 223, 233; meque eos in aeternae claritatis gaudio fac videre, 407.

CONFEssio, profession of Faith, martyrdom, confession of sins ${ }^{1}$.

It is well known that this indigenous Latin word as the nomen actionis of confiteri has the same basic meaning and has undergone an identical semantic development as the verb. From its Biblical origin where it was

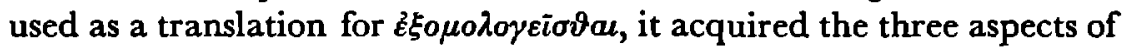
meaning; viz., confession of the glory of God or praise, confession of Faith, confession of sins.

In the orations the confessio laudis does not appear. The confessio fidei displays several nuances. Already in the Vulgate NT we find this term as a designation for Christianity: glorificantes Deum in obedientia confessionis vestrae, 2 Cor. 9, 13; Habeamus ergo pontificem magnum... teneamus confessionem, Hebr. 4, 14. In the orations we also have this meaning for the word confessio, but always modified by an objective genitive or an adjectival equivalent thereof. This latter circumstance reveals that the term was not technical. Thus we have: qui dedisti famulis tuis in confessione verae fidei... Trinitatis gloriam agnoscere, 774; Trinitatis, ejusdem individuae unitatis confessio, 897. In these the verbal element is predominent. But when in the collect of the vigil of Ss. Peter and Paul, we find: quos in apostolocae confessionis petra solidasti, 859, we realize that the nominal element prevails. So, too, in that expression which early became technical for "being a Christian", confessio nominis", that same shift of emphasis is apparent. In the secret of the third Mass on All Souls' Day: quibus tui nominis dedisti confessionem, 217; in the collect for Fer. $V$ infra Oct. Pasch.: qui diversitatem gentium in confessione tui nominis adunasti, 326; and in the solemn prayer for the Church: ut Ecclesia... stabili fide confessione tui nominis perseveret, 780; the expression means "the Christian Faith"; while the context of the secret for Fer. V infra Oct. Pasch.: ut confessione tui nominis et baptismate renovati, 1126, demands the verbal interpretation.

Along with the Biblical, we may discern also a legal influence in the semantic development of confiteri-confessio. From the general sense of "to admit in court", the words took on the special sense of "to admit being a Christian". Since such admission as a rule meant death, confessio came, in turn, to mean "undergoing the martyr's death". This martyr-death was regarded as a share in the passio Christi, and hence

1 Cf. Janssen, op. cit., p. 151 ff.; Mohrmann, Eludes, I², p. 30 ff.; Hoppenerouwers, op. cit., p. 28 ff., 41 ff., 210; Hans Rheinfelder, Kultsprache und Profansprache in den romanischen Ländern, Genève 1933, p. 101 ff.; but retractatio in Die Sprache 1, 1949, p. $56 \mathrm{ff}$.

2 C. nomen, p. 42 f. 
the martyrs were considered as having a share in the glory of Christ. It is not surprising, then, to find confessio modified by such adjectives as pretiosa, gloriosa, grata tibi, beata, honoranda. The martyrs are lauded as glorious because of their fortitude in martyrdom: qui gloriosos Martyres fortes in sua confessione cognovimus, 865. Their martyrdom is commemorated in an official liturgical celebration: cujus honoranda ${ }^{1}$ confessione laudis tibi hostias immolamus, 195.

There is another nuance noticeable in the meaning of this noun as it occurs in the official solemn prayers, namely, that the confessio of the martyrs is seen as being an aid to the Church. This may be regarded as a direct help, as in: Beatorum Martyrum nos... foveat pretiosa confessio, 76; qui nos sanctorum Martyrum... gloriosis confessionibus circumdas et protegas, 412 ; Sanctorum tuorum nos... confessio beata communiat, 1058. Again, it may be seen as a support to the gifts offered in the sacred action celebrated on the anniversary of the martyrdom, as the secret of the martyrs on 12 May has it: Sanctorum... tibi ${ }^{2}$ grata confessio... munera nostra commendet, 1055.

Only once does this noun occur in the sense of "confession of sins": ut reatus nostri confessio, indulgentiam valeat percipere delictorum, 338.

CONFITERI, to confess, to profess ${ }^{3}$.

This term, with so rich and varied connotations in Early Christian Latin literature, occurs only four times in the orATIONs. However, it has maintained several of its early nuances in these prayers. In that masterpiece of composition, the collect for the feast of the Holy Innocents: Deus, cujus hodierna die praeconium Innocentes Martyres non loquendo, sed moriendo confessi sunt, 213, we have an excellent expression of the fact that martyrdom is the greatest act of praise to God. The word confiteri implies both praise, and profession of the Divinity of Christ. The word means "to profess faith in" when it occurs in the following prayer: qui conceptum de Virgine Deum verum et hominem confitemur, 641. Finally, there are two instances where the verb means "to confess sins": qui omnem animam poenitentem et confitentem tibi, magis vis emendare quam perdere, 749; confitentibus tibi famulis tuis... relaxa peccata, 756. It may at first sight seem that confiteri in these latter prayers had become technical for the confession of sins, since neither time is the verb followed by peccata, delicta, or the like. However, peccata is so placed in each prayer that there can

1 Cf. Bastlaensen, op. cit., p. $156 \mathrm{ff}$. for this meaning of honorate.

2 In the Gel. Vetus (MoHLberg, 874) this secret reads as follows: Sanctorum thorum, domine, ...tibi grata confessio et munera nostra commende[ $n] t$... This reading without sit surely makes better sense than the text as it stands in the MR today.

3 Cf. confessio above, p. 25 f. 
be no mistaking it to be the implied object of confiteri. It is noteworthy that confiteri in the sense of "to praise" occurs only once, and that more as a subtle allusion than a clear expression of praise.

CORONA, crown.

Fraterna nos... Martyrum tuorum corona laetificet, 570. See the following. CORONARE, to crown with glory.

Though the crown was used very frequently in Early Christian literature and art as the symbol of the glory achieved by the martyr by reason of his victory over torture and death ${ }^{1}$, corona is found but once in the orations, 570 . The verb, too, occurs but once, and that in a collect which first makes its appearance in the eleventh century: Caelestis participatio sacramenti... meque cum illis gratia tua coronet aeterna, 106. Here it stands for the culminating act and end of the Eucharist; viz., the leading to overlasting joy in heaven. Upon a glance at the Index Verborum of the Veronense ${ }^{2}$, it becomes at once evident that these words were not very usual in this source either. Corona appears nine times in relation to martyrdom, and the verb seven times. Both words make their appearance only in VD passages ${ }^{3}$. This may be a factor contributing to their scarcity in the ORATIONs; but when we note that $p a l m a^{4}$ and victoria $^{5}$ each appear but once, and bear in mind that confiteri and martyrium are likewise infrequent, then we may conclude that either this terminology was considered too commonplace for the lofty style of the ORATIONs, or that with the passage of the phenomenon of martyrdom itself the enthusiasm for it, which was so alive in the days of the persecutions, also passed.

GREDERE, to believe, to have supernatural Faith'.

This verb is used in the orations in three different constructions. First there is that usage, which under the influence of the Greek, the

1 Teeuwen, op. cil., p. 29; Jos. Schrijnen, Uit het Leven der Oude Kerk, Bussum-Utrecht 1919, p. 141 ; Janssen, op. cil., p. 192 ff.; Vermeulen, op. cit., p. 91 ff.; Hoppenbrouwers, op. cit., passim; KarL. Baus, Der Kranz in Antike und Christentum. Eine religionsgeschichtliche Untersuchung mit besonderer Berücksichtigung Tertullians, Bonn 1940.

2 Mohlberg, p. 266.

3 This fact is another indication of the difference between the vocabulary of the ORATIONS and that of the VD passages (these are equivalent to what we today call the preface). Cf. MohrmanN, Liturgical Latin, p. $70 \mathrm{ff}$.

- Sanctarum Virginum Perpetuae et Felicitatis palmas incessabili devotione venerari, 163.

- Etiam in sexu fragili victoriam martyrii contulisti, 376.

- Cf. Th. Camelot, Credere Deo, credere Deum, credere in Deum, Les sciences philos. et théol. 1, 1941-42, p. 149 ff.; Chr. Monrmans, Credere in Deum. Sur l'interprétation théologique d'un fait de langue, Etudes, $\mathrm{I}^{2}$, p. $193 \mathrm{ft}$. 
Early Christians invented especially to designate the act of Faith in God, namely, credere in. Of this there are the following examples: in te speraverunt et crediderunt, 51, 208; credentes in te populos, 318; in quo speraverunt et crediderunt, 909 . Here the verb refers specifically to the theological virtue of Faith, which includes an act of the will, a movement of charity. Then, there is credere followed by an accusative with an infinitive or by a simple accusative: Unigenitum tuum Redemptorem nostrum ad caelos ascendisse credimus, 136; eam Genitricem Dei credimus, 320. In these latter, credere designates the act of Faith in so far as it is an attestation of a supernatural truth. In 318 credentes shows a tendency toward a semantic development whereby the participle came to mean "a true believer, a Christian". This development is seen in its completed stage in: Deus, salus aeterna credentium, 804; et saluti credentium perpetua sanctificatione sumenda concede, 979 . The absolute use of the participle as a substantive here shows just how technical it had become.

CREDULITAs, Faith'.

Ut Christiana plebs... credulitatis suae meritis augeatur, 757. This Late Latin word is undoubtly used as a substitute for fides, simply to add a certain solemnity by the use of a less familiar term.

DEvotus, dedicated to God ${ }^{2}$.

This word which in pagan antiquity meant "dedicated as a votive offering" or "accursed", had the meaning also of "devoted", "loyal" to a person or thing. It was used by Christian writers as "devoted to God", and thus came later to mean "pious". In the orations it has nearly always the same sense as we find, for instance, in St. Leo, namely, "a disposition of the will attached to God and determined to do the things that please Him"3. It is used either of persons as: (nos)esse devotos, 245; devotis famulis, 383 ; see also $395,525,557,658$; or of a disposition as: devoto servitio, 28 ; devoto pectore, 541 ; see also 616, 699, 716, 762.

DOCTOR, teacher.

In the ORATIONS this word appears only in the traditional reference to St. Paul: Doctoris gentium protectione muniamur, 315. Blaise mentions that it was frequently used to refer to the apostles. The technical expression "Doctor of the Church" is of much later origin.

DORMIRE, to sleep in death ${ }^{5}$.

1 Cf. TLL IV, p. 1150 f.; Mueller, op. cit., p. 89.

2 Cf. TLL V, p. 885; Rheinfelder, Kultsprache, p. 110.

R. Dolle, Léon le Grand. Sermons, II, Paris 1957, p. 11, note 3.

- Cr. Blaise, Dictionnaite, p. 289.

s Cr. TLL V, 1, p. 2030, esp. line 66 f.; Rheinfelder, Kultsprache, p. 18, 162. 
The concept of death as a sleep is of Hebrew origin. It occurs very regularly in the Bible, and this is, no doubt, why it became such a frequent term in Early Christian literature, and in grave inscriptions as well. It was likely too colloquial a word for the orations, for it appears but once: omnium... in Christo dormientium, 892.

ELECTUS, a chosen one, a Christian'.

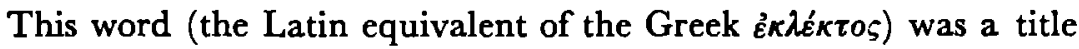
of honor for the Israelites in the OT, and was taken over by the Christians as the new Chosen People of God. It is used in the orations three times as a noun, always in the plural and each time in the eschatological sense: numerus electorum in superna felicitate locandus, 209; Sanctorum atque electorum tuorum largiri digneris consortium, 931 (in a Mass for the dead); ut in resurrectionis gloria inter sanctos et electos tuos resuscitatus respiret, 5 . Twice it has the general sense of "chosen by God". In each case it is used in conjunction with a Biblical metaphor designating a Christian; de vivis et electis lapidibus, $321^{2}$; electorum palmitum esse cultorem, $367^{3}$. The second of the orationes solemnes on Good Friday reads: et electum nobis Antistitem tua pietate conserva, $757^{4}$. Here electum has a much narrower meaning as a title of honor and is very much akin to a title of address which O'Brien mentions as having been used twice by St. Ambrose and once by Ennodius ${ }^{5}$.

FAMILIA; see LEGAL TERMS, p. $154 \mathrm{f}$.

FAMULARI, to serve God, i.e. to live a morally good life; to perform the sacred functions of the ministry ${ }^{6}$.

Found since Cicero, this verb became more frequent since Tertullian. It is rare in the Vulgate, which prefers servire. Thus, where Tertullian quotes Deut. 6, 3: illi famulaberis soli ${ }^{7}$, we note that famulari is used to

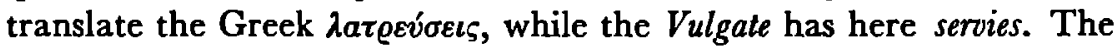
concept of living a life according to the commandments as a "service" of God is of Biblical origin though ${ }^{8}$. It is in this meaning that it occurs in:

1 Cf. TLL V, 2, p. 386; BartelinK, op. cit., p. 105.

Cf. Eph. 2, 20.

af. Jn. 15, 2, 5 .

- In the Gel. Vetus the text reads: electos nobis antestites, Mohlmerg, 403. It includes under one head the prayer for the Pope and for the local bishop. See also antistes, p. $20 \mathrm{f}$.

- Mary Bridget O'Bren, Titles of Address in Christian Latin Epistolography to 543, Washington, D.C. 1930, p. 158: Sanctus Damasus Romae Ecclesiae sacerdos, judicio Dei electus, Ambr., Ep. 17, 10; domine imperator auguste, divino electe judicio, ibid. 1, 10.

- Cf. TLL VI, 1, p. 261; LORIÉ, op. cit., 79 f., 93 f.

7 Scorp. 2.

- Cf. servire, p. 56. 
ut tibi jugiter famulentur, et nullis tentationibus a te separentur, 381; qui tibi digne meruit famulari, 540; devoto tibi pectore famulantes, 541; percepta misericordia, libera tibi mente famulemur, 914; ut, divinis rebus inhaerentes, et corpore tibi famulemur, et mente, 918. In pagan Latin this verb was sometimes synonymous with colere or venerari. It occurs in this sense sometimes in the sacramentaries also' ${ }^{1}$, but it does not occur as such in the ORATIONs.

famulus, servant of God; a Christian².

Like famulari, this word, too, was used in the Vetus Latina where the

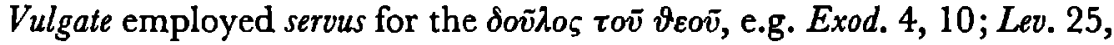
$55 ; 1 s .42,19$. It is found also in Early Christian writings with the added genitive - Dei, domini, or Christi - as a designation for Christian. In the ORA'rions the adjective tuus replaces the genitive. Its prolific use in these prayers is due to the fact that humility is a basic attitude of the Christian before God, and so he calls himself "God's servant". But there is undoubtedly also a linguistic factor which explains why famulus was preferred to servus. The former was by far not so common a word, and besides, it had a poetic background. And thus it became the technical liturgical term.

It refers to the servants of God, the Christians in general: Da famulis tuis indulgentiam, 156; famulos tuos... protege, 1133. Sometimes in this sense it is used in apposition with nos, e.g., nos famulos tuos, 122. Again certain members of the Christian community are mentioned: The Pope, 239, 590, 731; the king, 578; the bishop or priest, 1111, 743, 779; the sick, 234, 804; travelers, 451, 902; friends, 312, 683; penitents, 749, 756 ; a bride (famula), 434. The use of the same term for all these indicates a certain equality of all before God. Even when the word is applied to the Pope or a bishop, it never refers to his office or rank, but simply to his status as servant of God.

Ordinarily the masculine plural form stands for all the Christians. There are a few exceptions; the secret for Dom V p. Pent., for example, has: oblationes famulorum famularumque tuarum, 901. But the phrase: animae famulorum famularumque tuarum is usual in prayers for the faithful departed, probably because it became a fixed expression.

FIDELES, the faithful, the Christians ${ }^{3}$.

This word exhibits almost throughout, in the ORATIONs, that final

1 Cf. Bastlaensen, op. cit., p. $71 \mathrm{ff}$.

2 Cf. TLL VI, 1, p. 266 f.; LoriÉ, op. cit., p. 79 f., 93 ff.; Ernestus Diehl, Insctiptiones Latinae christianae veteres, III, Berlin 1961, p. 353, states that famulus Christi, famulus Dei were used in Gaul and Spain for christianus.

$s$ Cf. TLL VI, 1, p. 655; JANSSEN, op. cit., p. 215 f. 
stage of semantic development in which the adjective is used regularly as a noun in a concrete technical sense. One need quote only an example or two of the \pm 34 instances, because they all have the same meaning; viz., "true believers, Christians": tuorum fidelium cordibus infudisti, 312; Fideles tui... per dona firmentur, 564. There are a few examples, however, where the adjective retains its value, grammatically at least: Benedictionem tuam... populus fidelis accipiat, $82 ;$ Da... fidelibus populis... laetari, 180, These may be considered pleonastic, for populus and fideles are near synonyms in these prayers. But in the postcommunion for Dom. IV Quadr.: ut sancta tua... fideli semper mente sumamus, 172, fidelis has its full adjectival worth and means "having supernatural Faith". In the prayer for the bride it has the Christian sense of "with Faith" in the petition: fidelis et casta nubat in Christo, and the profane sense of "faithful" in: sit... longaeva et fidelis, ut Sara, 434.

FIDELITER, with Faith, faithfully'.

The usual meaning of the adverb in the orations is "with Faith". Thus in the postcommunion for Dom. IV p. Pasch.: ut per haec, quae fideliter sumpsimus, 34, it points up the element of Faith in the reception of the Eucharist, and in the secret for Dom. VI p. Pent.: ut, quod fideliter petimus, efficaciter consequamur 903 (see also 461), it emphasizes the need of Faith when placing a petition before God. While the obvious translation for: $a b$ omnibus tibi gradibus fideliter serviatur, 758, is "that it (the Church) may be faithfully served by all the orders", still the idea of Faith is not excluded from the context.

FIDEs, supernatural Faith ${ }^{2}$.

While all the instances of this key Christianism have basically the same meaning, still its usage in the ORATIONs displays several nuances in its definition. In the first place fides is a gift from God: quibus dedisti fidem largiaris et pacem, 264; auge fidem et intellectum catechumenis nostris, 777. Furthermore, it is a gift which enables man to know God, as the collect of Epiphany has it: qui jam te ex fide cognovimus, 351. Sometimes it is seen as a personal act of the Christian. Thus the Faith required at Baptism is called "thirst" in the prayer for the blessing of the font: ut fidei ipsius sitis, baptismatis mysterio animam, corpusque sanctificet, 803. On the feast of St. Thomas the Apostle there is the request in the collect that we may imitate his faith: et fidem congrua devotione sectemur, 162; see also 157, 570, 748,780 . This Faith as a personal act is attributed to the martyrs expecially. On the feast of St. Prisca we find: et tantae fidei proficiamus

1 Cf. TLL VI, 1, p. 660 .

${ }^{2}$ Cf. TLL VI, 1, p. 689; Mohrmann, Etudes, I², p. 118; Bartelink, op. cit., p. 143. 
exemplo, 190; on that of Ss. Euphemia, Lucia and Geminianus: etiam fidei constantiam subsequamur, 834; see also 872, 943. The interior character of Faith is brought out by its being juxtaposed to external acts: hoc in nostro resplendeat opere, quod per fidem fulget in mente, 176; ut sacramentum vivendo teneant, quod fide perceperunt, 334. Finally it has the concrete sense of the objective body of truths known as the "Christian Faith", or the "true Faith": quibus fidei christianae meritum contulisti, 620; quem tibi vera supplicatio fidei christianae commendat, 721; in confessione verae fidei, 774; In mentibus nostris... verae fidei sacramenta confirma, 641. A curious thing for us who are so apt to consider the three theological virtues - Faith, Hope, and Charity - as an almost inseparable trilogy, is the fact that these three occur together but once: da nobis fidei, spei et caritatis augmentum, 759.

GENTEs, the Gentiles, the non-Christians'.

In one instance gentes has clearly the or meaning of "the Gentiles"

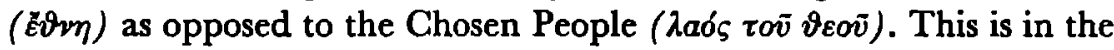
oration for the feast of Epiphany: Unigenitum... gentibus stella duce revelesti, 351. In the title for St. Paul, Doctor gentium, 315, it seems still to imply the distinction between Christians who were converts from paganism and those who were converts from Judaism. In other ORATIONs the word stands for non-Christian peoples: excita in omnem justificatarum gentium plenitudinem potentiam, 205; id in salutem gentium per aquam regenerationis operaris, 211 ; qui diversitatem gentium... adunasti, 326; gloriam tuam omnibus in Christo gentibus revelasti, 780.

GLORIA, glory².

This noun maintains in the ORATIONs something of the richness and depth of meaning which it had in Early Christian Latin, though not its full vitality. It has reference to the glory of God and of Christ. The concrete meaning of Kebod Jahweh as the Person of God who revealed Himself to men is contained in the word in: gloriam tuam... in Christo... revelasti, 780. One aspect of God's glory is specifically mentioned in: Sicut gloriam divinae potentiae munera... oblata testantur, 1064. The word gloria is also applied to the mystery of the Blessed Trinity: aeternae Trinitatis gloriam agnoscere, 774. One of the meanings of the Hebrew "glory of Jahweh" is a physical phenomenon indicative of the divine presence. It is used in connection with Mount Sinai, the tabernacle,

1 Cf. Einar Löfstedt, Late Latin, Oslo 1959, p. 74; Mohrmann, Etudes, I², p. 27 f.

2 B. BoTte, La gloire du Christ dars l'Évangile de Saint Jean, QLP 12, 1927, p. 65 ff.; Rheinfelder, Kultsprache, p. $282 \mathrm{ff}$; Steinhemer, op. cit., p. 33 ff.; MohrmanN, Etudes, I', p. 285 ff.; Vermeulen, op. cit., passim. 
or the temple. This is the idea behind the phrase: "templum gloriae suae", 1 which is applied metaphorically to the Christian as the dwelling place of the Holy Spirit: ut Spiritus Sanctus... templum nos gloriae suae... perficiat, 879. Gloria is used in a form of doxology in the phrase: ad laudem, et gloriam nominis tui, 790; see also 720, 887-2.

In referring to the glory of the Resurrection, the light element, which was so common in the OT apparitions of God, prevails in the collect of the Mass for the Easter Vigil: Deus, qui hanc sacratissimam noctem gloria Dominicae Resurrectionis illustras, 346 . Here gloria indicates a real manifestation of God's brightness and power. The concept is more abstract in the postcommunion of the Annunciation, though the same expression is used: per passionem ejus et crucem, ad resurrectionis gloriam perducamur, 575 . Here the Resurrection is regarded as the victory over death. That victory over death is in turn seen as the source of "salvation" in the secret for the Holy Cross: perenniter ejus gloriae salutaris potiamur effectu, 657.

We pass now to a consideration of this word as applied to the saints. It is used especially in reference to martyrs: qui sanctis tuis Abdon et Sennen ad hane gloriam veniendi copiosum munus gratiae contulisti, 442 . Here gloria means the martyrs' personal participation in the glory of God, a privilege which they have received by reason of their victory. It has this same meaning in the collect for Fer. V p. Dom. III Quadr. (originally the prayer for the feast of Ss. Cosmas and Damian), if we accept the reading as it now stands in the MR:: qua et illis gloriam sempiternam, et opem nobis ineffabili providentia contulisti, 667. Qua stands for solemnitas and has the sense of "the day on which". Just as on 12 October we say: "This is the day on which Columbus landed on San Salvador", so on the feast of the saints we celebrate the day on which God gave them eternal glory ${ }^{3}$. The word is closer in meaning to the profane sense of "honor, renown" in prayers which speak of celebrating the glory of apostles and martyrs. It must always be borne in mind though that renown for a Christian is never the same as the purely profane Roman gloria $^{4}$. It always contains

1 This expression recalls the dedication of Solomon's temple, 1 Kings 8, and 2 Chr.

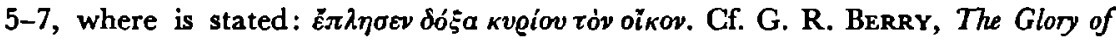
Fahweh and the Temple, Journal of Biblical Literature 56, 1937, p. $115 \mathrm{ff}$; see further p. 57 , note 3 .

The MS, Vat. Ottob. lat 313, which is one of the best of the Alcuin editions of the Gregorianum, and the Angouleme have the reading which is in the MR. The Gel. Vetus and the Sacramentary of Prague read quia. Steinheimer (op. cit., p. 39) accepts this reading and hence interprets gloria in the sense of "honor or renown".

- Cf. translation by Chr. Mohrmann in Jesus, Mary and Joseph Daily Missal, Benziger Brothers, New York, 1962, p. 177.

- Cf. A. D. Leeman, Gloria. Cicero's waardering van de roem en haar achlergrond in de 
the notion of honor in the eyes of God, and in the eyes of Christians on earth. In this category we have such prayers as the collect and secret for Ss. Simon and Jude: da nobis eorum gloriam sempiternam et proficiendo celebrare, 408; Gloriam... sanctorum Apostolorum... perpetuam venerantes, 571 ; the secret for the feast of the Chair of Peter: ut quod ${ }^{1}$ pro illius gloria celebramus, nobis prosit ad veniam, 516; and the postcommunion for the Commemoration of St. Paul: quae pro illius celebrata sunt gloria, 815-4. There are times, too, when gloria means the concrete cultic honor rendered to the saints. Of this we have examples in: per haec beata mysteria illis gloriam contulisti, 650 ; ut, quod illis contulit gloriam, nobis prosit ad salutem, 1017; quae (mysteria), sicut tuis Sanctis ad gloriam, ito nobis... ad veniam prodesse perficias, 1079 . In the petition, Pro defuncto uno: ut in resurrectionis gloria inter sanctos et electos resuscitatus respiret, 5, we have still another example of the specifically Christian concept of glory; this time consisting in fellowship with the saints and elect. Under the head of "honor" in the Christian sense would come also the phrase: Deus, tuorum gloria sacerdotum, 464.

The third nuance of gloria is found in its eschatological sense pure and simple, i.e., not considered as special reward of the martyrs. Here it is somewhat more abstract: concede; ut... aeternitatis gloriam consequamur, 212 ; ut per haec sancta... gloriam aeternae beatitudinis acquirant, 683 . It is seen as the direct effect of the Eucharist: ut munera... et medelam nobis operentur, et gloriam, 514; ut per haec piae devotionis officia, ad caelestem gloriam transeamus, 1106.

GLORIOSUS, of glory, glorious ${ }^{2}$.

This adjective is laden with the full weight of the gloria Dei when it modifies Ascensio : quae pro Filii tui gloriosa Ascensione deferimus, 1110; for by His Ascension Christ entered with His human nature into the Glory of God. Mary is called gloriosa because she shares the glory of God in a special way by reason of her unique prerogatives. Gloriosus is a regular epithet of the martyr in Christian Latin ${ }^{3}$, and hence we expect to find it in this connection also in the orations: qui gloriosos Martyres fortes in sua confessione cognovimus, 865 . It has less of a formulary nature in: sicut illos passio gloriosos effecit, 1107. It stands in the place of an objective

hellenistische wijsbegeerte en de romeinse samenleving, Rotterdam 1949, p. 175; VERMEULEN, op. cit., p. 28-108; STEINHeImer, op. cit., p. 38-40; The last correctly sees the Roman idea of "renown" in the liturgical celebrations of the gloria of the saints; but he is not, we think, sufficiently aware of the semantic development of this word.

1 It was the Eucharist which ordinarily constituted the cultic act on such feasts.

2 Cf. Vermeulen, op. cit., p. 69, 100, 104 ff., 183, 227; Steinheimer, op. cit., p. 44 ff.

3 Cf. Vermeulen, op. cit., p. 106. 
genitive in : qui nos sanctorum Martyrum... gloriosis confessionibus circumdas, 412 , in as much as martyrdom leads to glory. Used with sedes in the place of a genitive of definition, it represents the eternal happiness of Heaven in the prayer for a departed bishop: in caelesti sede gloriosa semper exsultet, 844. The intercession and prayers of the saints are also termed gloriosus: gloriosa intercessione, 122, 649; precibus gloriosis, 658; gloriosa merita, 697. In these last it may be considered to take the place of a subjective genitive, but it is evident that its usage is somewhat trite; the word no longer has the full vigor and depth of meaning which it had in Christian literature at least up to the middle of the third century.

HUMILIs, humble, in the sense of having the proper attitude before God and one's fellow man"1.

As Dom Dekkers has pointed out, this adjective usually has in Scriptural language more of an ethic content than does the noun. This is evident also in its use in the ORATIONs: ut esse... mereamur et inter prospera humiles, et inter adversa securi, 37; Deus, celsitudo humilium, 205; Deus, qui superbis resistis et gratiam praestas humilibus, 450 . This last is almost a literal quotation from James 4, 6. It seems that in: quas digna mente non possumus celebrare, humilibus saltem frequentemus obsequiis, 163; and vota humilium respice, 950, the word humilis is under the influence of the curial style, and has lost something of its full import by becoming a fixed expression of modesty before one's betters.

hUMIITAS, humility ${ }^{2}$.

In the ten times that this word appears in the orations, it exhibits several shades of meaning, always, of course in bonam partem. In the first place, there is the sense which it already had in the OT, "man's proper attitude before God". Such is its content in: Da Ecclesiae tuae... superbe non sapere, sed tibi placita humilitate proficere, 155. Here it has reference to the virtue of humility. But for the most part this noun comes closer to the sense of "an ontological state of lowliness". Such is its content frequently also in Sacred Scripture ${ }^{3}$, e.g. Vide humilitatem meam, Ps. 9, 14; Quia respexit humilitatem ancillae suae, Lk. 1,48 . It stands for the human nature of Christ in that expressive word-play humilitate... erexisti in the collect for Dom. II p. Pasch.: qui in Filii tui humilitate jacentem mundum erexisti, 364. There are two examples in which the virtue of humility is

1 Cf. following note.

${ }^{2}$ Cf. Joe Kwa Liang, Het begrip deemoed in I Clemens. Bijdrage tot de geschiedenis van de oud-christelijke ethiek, Utrecht 1951, p. 123 ff.; Bartelink, op. cit., p. 156; E. DekKERs, De humilitate, Horae Monasticae, I, Tielt 1947, p. $67 \mathrm{ff}$.

3 For more examples, see Dekkers, Hotae monasticae, I, p. 68. 
brought into relationship with the low state assumed by the Son of God in the Incarnation and the Passion. The collect for Dom. II Pass. has: qui humano generi ad imitandum humilitatis exemplum, Salvatorem nostrum carnem sumere, et crucem subire fecisti, 783 ; and that Ad postulandum humilitatem: concede nobis verae humilitatis virtutem, cujus in se formam fidelibus Unigenitus tuus exhibuit, 450 . This relationship shows that true Christian humility (verae humilitatis virtus) means not only a lowly attitude of mind, but a real emptying of one's self, as St. Paul expresses itself also in Phil. 2, 7-8: sed semetipsum exinanivit, formam servi accipiens... Humiliavit semetipsum factus obediens usque ad mortem.

The remaining seven examples represent fixed expressions: humilitatis nostrae... ministerio, 39, 754; preces humilitatis nostrae, 217, 414, 743, 819; and nostrae humilitatis oblatio, 839 . While the basic meaning in these instances is "the lowly state of sinful man", there is also discernible in this use of humilitas an influence of the language of officialdom, where the use of the abstract for the concrete was frequent ${ }^{1}$. Thus, instead of such a phrase as preces humilis servi, we find preces humilitatisnostrae. O'Brien cites a goodly number of incidents in which humilitas is so employed by Christian authors².

HUMILITER, humbly.

This adverb indicates man's proper attitude before God in prayer in : humiliter implorantibus, 769; humiliter deprecantes, 1083. But in the postcommunion for St. Hermes: quaesumus... ut... quae humiliter gerimus, salubriter sentiamus, 971 , it has reference to the performance of the external rite since it modifies gerimus. Hence it would seem more plausible to paraphrase the prayer thus: "that we may experience the salutary effect of the rite, which we perform by means of our lowly human actions", rather than to say: "that we may experience the salutary effect of the rite which we perform in a humble frame of mind". The former interpretation seems more in line with the general nature of secrets and postcommunions; viz., to be more concerned with the effects which flow from the sacred actions as such, than with the effect which man's moral disposition has upon their efficacy.

ILLUMinare, to give information of the Gospel, to convert, to give supernatural knowledge ${ }^{3}$.

This verb, which was rare outside of Christian authors, was infused

1 Cf. Mohrmann, Etudes, II, p. $126 \mathrm{f}$.

2 Cf. O'Brien, op. cit., p. 73 ff.; Mutller, op. cit., p. 228.

3 Cf. TLL VII, p. 391 ff.; von Harnack, Terminologie der Wiedergeburt, p. 126 f.; YSEBAERT, op. cit., p. $158 \mathrm{ff}$. 
with new meaning by its being employed as one of the Latin equivalents of the LXX and the NT Greek $\varphi \omega \tau i \zeta \varepsilon \varepsilon v$. To the Jewish tradition are added the specifically Christian nuances. Though it is sparse in the "sacramentaries ${ }^{1}$, some traces of its earlier grandeur are still noticeable. Thus it stands for "the bringing of the enlightenment of the Christian Faith through the preaching of the Gospel" in the collect for the feast of St. John the Evangelist: ut beati Joannis Apostoli tui et Evangelistae illuminata doctrinis, 520. Conversion was seen as enlightenment in the NT. Something of that idea is contained in the following: illumina corda nostra; ut tua valeamus implere praecepta, 414 ; illumina... corda nostra... ut digna ac placita... cogitare, et te sincere diligere valeamus, 358 ; animas nostras... purges, illaesasque custodias, et Sancti Spiritus gratia illuminare digneris, 602. In these it is obviously moral help which is petitioned by the verb illuminare. Then there is the metaphorical sense of "to give information" which is attributed, on the supernatural level of course, to the Holy Spirit: Mentes nostras... Paraclitus... illuminet : et inducat in omnem... veritatem, 679. This metaphorical sense is much broader in: Sancti Spiritus gratia, ... corda nostra illuminet, 1035.

ILLUSTRARE, to illuminate, to give supernatural knowledge ${ }^{2}$.

A synonym of illuminare in Christian Latin and one of the verbs which was used to translate the Greek $p \omega \tau i \zeta \varepsilon \nu$, illustrare displays a trend somewhat different from that shown by the former. In the first place it retains the concept "to illuminate, to make bright", when it is used with terms recalling the Biblical idea of the appearance of the $\delta \delta \xi a$ rov $\vartheta \varepsilon o \tilde{v}$ We have three examples of this: the collect of Dom. III Adv.: et mentis nostrae tenebras, gratia tuae visitationis illustra, 64; the collect of Sabb. Sant.: qui hanc sacratissimam noctem, gloria Dominicae Resurrectionis illustras, 346; and the collect for Ded. Eccl.: templum hoc potentia tuae inhabitationis illustra, 380. In the first, visitatio gives the epiphany idea, in the second, gloria is the one element of the $\delta \sigma^{\prime} \xi a \tau o \bar{v} \vartheta \varepsilon o v$, and in the third, potentia expresses another element of it. The nomen actionis, illustratio, has the intransitive sense of "being bright" or "splendor" - once again the light element in the glory of God - in the collect for the first Mass of Christmas: qui hane sacratissimam noctem veri luminis fecisti illustratione clarescere, 347.

The broader metaphorical sense of "to give supernatural knowledge" is found in the first part of the collect of St. John the Evangelist: Eccle1 It occurs but twice in the Veronense (Cf. BRUYLANTs, Concordance, s.v.) and 8 times in the Gregorianum (Cf. Wortregister in the Lretzasann edition, s.v.). This may be due to the fact that it was too common a word in the colloquial Christian language, but it may also be the result of the fact that it was used technically for Baptism.

'Cf. TLL VII, p. 399; Vermeulen, op. cit., p. 149, 185; Ysebaert, op. cit., p. 159 ff. 
siam tuam benignus illustra,520.Twice illustratio is used in this metaphorical sense for the action of the Holy Spirit: qui... corda fidelium Sancti Spiritus illustratione docuisti, 349; et lux tuae lucis corda eorum... Sancti Spiritus illustratione confirmet, 854. To be noted is the fact that "to teach" is explicitly mentioned in the collect for Pentecost, 349. Nor is the moral sense, which we found also in illuminare, lacking: Mentes nostras... lumine ...claritatis illustra: ut videre possimus, quae agenda sunt; et, quae recta sunt, agere valeamus, 678; Sanctificato hoc jejunio..., tuorum corda fidelium... illustra, 1046. Once it occurs in a very broad general sense for both supernatural knowledge and moral strength: Oblatis muneribus... Ecclesiam tuam benignus illustra, $729 \mathrm{~b}$.

INIMIcus, enemy, the devil'.

This noun has the proper literal sense of "personal enemy" in 165, 732, and 587. The use of inimicus in the special sense of "the great enemy, the devil" may be considered to be part of the general human tendency whereby men, because of a certain religious taboo, do not dare to pronounce the actual name of the evil one. In the ORATIONs it occurs but twice in this special sense. Once it has reference to the devil's power over mankind in general: ut inimici a nobis expelleres potestatem, 438; and the second time it regards the power which the devil may have over a soul after death: ut non tradas eam in manus inimici, 208.

INSTAURARE, to resotre anew in Christ ${ }^{2}$.

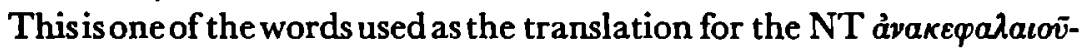
$\boldsymbol{\sigma}^{2} a \iota^{3}$. Of it Herz says: "Alle Heislwirkungen Gottes fasst Cyrill wie auch andere Väter seit Irenäus zusammen mit dem Ausdruck

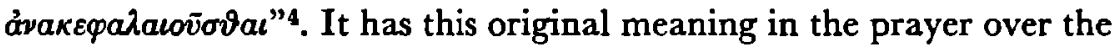
people for Tuesday in Holy Week: ad beneficia recolenda, quibus nos instaurare dignatus es, tribue venire gaudentes, 41 , for here we pray that we may enter with joy into the celebration of that work of mercy (beneficia) whereby God has redeemed us. For the other three instances: Hujus nos... sacramenti semper novitas natalis semper instauret, 631 ; et caelestibus... instaurent alimentis, 709; Sacramenta quae sumpsimus... spiritualibus nos instaurent alimentis, 991-2, it seems that two interpretations are possible. If we consider the Eucharist as making the Redemption effective in

1 Cf. Mohrmann, Sondersprache, p. 100; H. Martin, II - Spanish Inseriptions - Additional Comment, Am. Journal of Philology 35, 1914, p. 400 ff., esp. p. 411.

2 Cf. Blaise, Dictionnaire, p. 456; Louis Brou, Les oraisons dominicales. De l'Avent à la Trinite, Bruges 1960, p. 51.

Eph. 1, 10; Rom. 13, 9; Jn. 14, 20.

- Martin Herz, Sacrum Commecium. Eine begriffsgeschichtliche Studie zur Theologie der römischen Liturgiesprache, München 1958, p. 146. 
the present, then we may interpret this use of instaurare as an example of the appropriation of Scriptural concepts of Redemption specifically to the action of the Eucharist. However, there is another possibility, namely, the sense "to renew spiritual forces". This latter interpretation seems more obvious since the word occurs in postcommunions, and twice it is accompanied by alimentis.

JEJUNIUM; see MEDIGAL TERMS, p. $182 \mathrm{f}$.

JUSTITLA, justice according to God's law, righteousness'.

Though a Roman law term, justitia here derives from the Biblical usage, where it expresses a relation to God - the justice which comes from the observance of the Divine Law. This is especially evident in the collect for Dom. III p. Pasch. where the familiar Biblical term via justitiae appears: Deus, qui errantibus, ut in viam possint redire justitiae... lumen ostendis, 336. But is is also clear in: qui nostrae justitiae fiduciam non habemus 31; and sectando justitiam, a culpa jejunet, 857. It is interesting to note that justitia is never used in the orations for "the works of Christian liberality", a meaning which Janssen and Pétré have shown it to have throughout Early Christian literature ${ }^{2}$.

Justus, just ${ }^{3}$.

Two trends can be noted in the use of this word in the orations. On the one hand it is used of works which are in accordance with the Divine Law: Deus a quo... justa sunt opera, 201; Per hujus... operationem mysterii... justa desideria compleantur, 813. On the other hand it displays a further semantic development whereby it comes to be used as a noun meaning "those who live according to the Divine Law". It is contrasted to sinners in: Deus, qui et justis praemia meritorum, et peccatoribus per jejunium veniam praebes, 338. The semantic development has reached its limit when justi becomes a technical term for the saints in heaven ${ }^{4}$, those fixed in justice: In tuorum... pretiosa morte justorum sacrificium illud offerimus, 642; quae et pro tuorum tibi grata sint honore justorum, 707; ut animam famuli tui... in congregatione justorum aeternae beatitudinis jubeas esse consortem, 851. Note that we have here the same phenomenon that we find with the word sanctus. Though in Early Christianity all the Christians

1 Cf. Janssen, op. cit., p. 215 f.; Mohrmann, Etudes, II, p. 206.

2 Cf. Janssen, op. cit., p. 215; Hélène Pétré, Caritas. Etude sur le vocabulaire latin de la charité chrétienne, Louvain 1948, p. $246 \mathrm{ff}$.

- Cf. Janssen, op. cit., p. 216.

- Sometimes justus had in Christian literature the technical sense of "a Christian", but there are no instances of this stage in the semantic development to be found in the ORATIONS. 
were called "saints" - those on earth, as well as those who had died the word gradually came to be limited in meaning so as to be applied specifically to the "saints" in heaven".

LEX, the law of Moses, the Christian law2.

This word appears only once as the lexicological "calque" (it is a Hebraism from Thorah by way of the Greek vó $\mu 0_{5}$ ) for "the Law of Moses". This is in the prayer for Sabb. Sanct.p.prophetiam IV: ut illa legis iteratio fieret etiam nostra directio, 205. In the secret of the nuptial Mass: pro sacra connubii lege munus oblatum, 1132, it has more of a legal sense and the phrase means "the ritual action offered in behalf of the holy bond of Matrimony".

MAjEstas, the majesty of God, God Himself.

As has been amply demonstrated elsewhere ${ }^{3}$, majestas was used to

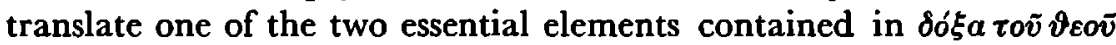
(the Hebrew, Kebod Jahweh). While claritas frequently rendered the concept of light, majestas was the usual term for the element of power contained in this all-important term. In the orations the Biblical influence on the word majestas is evident. God's powerful protection is petitioned by the phrase: ad protegendum nos, dexteram tuae majestatis extende, 764, 884, 950. Potentia is identified with majestas in the collect for the feast of the Holy Trinity: et in potentia majestatis adorare unitatem, 774. Then, too, the typically Biblical phrase: oculis tuae majestatis, 132, 530,586 occurs three times. In the phrase: quod singuli obtulerunt ad majestatis tuae honorem, 383, majestas stands for the person of God Himself. There are other turns of speech also in which this same phenomenon is discernible. Such for example are: Majestatem tuam suppliciter deprecamur, 381 , and, with now and then a slight variation, $668,669,670,765,794$, 906, 1041, 1108; majestati tuae obtulimus, 474, 600,683, 699, 877, 898, 1089 ; majestati tuae servire, 762 , majestati tuae famulari, 788 . In all of these there is apparent the influence of the court style. It is true that the term Majestas tua was used as a title of honor for the Roman emperors as early as the time of Horace: neque paroum carmen recipit majestas tua. O'Brien states that it was very rarely used by Christian authors as a title of address, and was applied to the emperor only. Perhaps some of the early feeling that the word expressed an attribute which was

1 Cf. electus, p. 29.

2 Cf. Mohrmann, Etudes, I², p. 47, 49.

3 Cf. B. Botte, Majestes, in Botre-Mohrmann, op. cit., p. 113 ff.; Mohrmann, Etudes, I², p. $284 \mathrm{ff}$; STEINHeImer, op. cit., p. 59 ff.

- Epist, 2, 1, 258.

- Cf. O'Brien, op. cit., p. 15. 
peculiar to God alone was still strong in the sixth century when it became general ${ }^{1}$. The added fact that, unlike gloria, this noun is never attributed even to the martyrs in the orations but is reserved for God alone lends weight to this supposition. In conclusion, then, we may say that the Biblical influence is seen in the fact that majestas is used with other Biblical phrases, especially those which express strength, and from the fact that it is applied exclusively to God. The influence of the curial style is seen in the use of the abstract for the concrete.

MAGMIFICARE, to praise, to magnify 2 .

This word, which was rare in pre-Christian Latin, is one of the terms which the translators and interpretors of Scripture used to convey the idea contained in the Greek $\delta o \xi \alpha$ ' $\zeta \varepsilon v$. It really means "to recognize the majesty of God". It occurs only once in the orations: Magnificet te... sanctorum tuorum... beata solemnitas, 667 . It is somewhat of a cliché here, but it does express the essential purpose of a liturgical celebration.

MunDus, the world where mankind dwell, mankind in general, the sinful world as opposed to the truly Christian life ${ }^{3}$.

This noun displays three shades of meaning in the orations. First of all, it has the proper profane sense of "the universe": Deus, qui illuminas omnen hominem venientem in hunc mundum, 358; qui infirma mundi eligis, ut fortia... confundas, 787 . In the second place, it refers to the generality of mankind. Here we have such examples as: totius mundi tribuisti relaxari delicta, 54; quae in ara Crucis etiam totius mundi tulit offensam, 592; ut in Abrahae filios,... totius mundi transeat plenitudo, 211 . With the freedom of the Church and its spread throughout the "world", the concept "the Church, or Christianity" came to be coterminus with "mankind". Hence when in the collect for Fer. VI p. Dom. IV Quadr. there is the phrase: qui ineffabilibus mundum renovas sacramentis, 373 ; and in that for Fer. II infra Oct. Pasch.: qui solemnitate paschali, mundo remedia contulisti, 448, it may be considered as synonymous with Ecclesia. The affairs of men, the political relation between peoples is designated by mundus in the collect for Dom. IV p. Pent.: ut et mundi cursus pacifice nobis tuo ordine dirigatur, 170. Finally the word has the specifically Christian sense, "the wicked world": da... illam quam mundus dare non potest pacem, 201; pro amore tuo prospera mundi despicere, 292; qui in Filii tui humilitate jacentem mundum erexisti, 364 ; ut hoc sacramentum... sit contra omnia mundi pericula

1 Cf. Botte, in Botte-Mohrmann, op. cil., p. 111.

2 Cf. TLL VIII, p. 106, BotTe, QLP 12, 1927, p. 67; MatzKow, op. cit., p. 47; Mohrmann, Eludes, I², p. 328.

3 Cf. MohrmanN, Etudes, I², p. 334 f.; Lorif, op. cit., p. 60. 
firmamentum, 923. In the expression, Salvator mundi, it seems that this last meaning is also present.

Nomen, the Holy Name of God, the Christian Faith'.

For the most part the usage of nomen in the ORATIONs reflects the Biblical usage where Shem Jahweh (övora) was used in a religious sense to designate the person of God Himself. Here we find a number of set expressions: invocare nomen tuum, to pray, 439, 769, 1039; ad laudem nominis tui, 603, 790, 846; see also 451, 788; ad honorem nominis tui, 901, 1137; propter gloriam nominis tui, 720; tui nominis magnificentiam, 781. Gifts are offered nomini tuo, 487, 627, 700, 727, 755, 881, 941. Love for God is petitioned in the words: amor nominis tui, 467, 863, 1033. The expression in the collect for Dom. infra Oct. Nat.: ut in nomine dilecti Filii... mereamur bonis operibus abundare, 761, recalls the words of St. Paul: Omne, quodcumque facitis in verbo aut in opere, omnia in nomine Domini Jesu Christi ${ }^{2}$. The meaning is, then, "by Christ's power, authority, and grace", i.e., reference is made to the person of Christ as mediator ${ }^{3}$, and not to a devotion to "the Holy Name of Jesus" as Haessly insinuates". Whether the further semantic development of this word, in which confessio nominis came to be used for the older confessio nominis Christi so that nomen used independently, became the equivalent of "the Christian Faith", was brought about solely under the influence of the Greek, or whether the specifically Latin influence of such a phenomenon as nomen Latinum also played a role in this, need not detain us here. The fact is that this technical use of the phrase occurs in the orations a number of times. The collect for Fer. $V$ infra Oct. Pasch. has: qui diversitatem gentium in confessione tui nominis adunasti, 326; see also 217, 780, 1126. In the collect for Dom. III p. Pasch., nomen is used independently in a context where it can only mean "the Christian Faith": da cunctis qui christiana professione censentur, et illa respuere, quae huic inimica sunt nomini, 336.

Finally, there is one case in which we find the peculiar Latin usage of nomen with a genitive to designate a thing'. It is in the prayer for Sabb. Sanct. p. proph. III: qui et vinearum apud te nomine censentur, et segetum,

1 Cf. Chr. Mohrmann, A propos de deux mots controversés de la latinité chrétienne. Tropaeumnomen, VC8, 1954, p. 156 ff., esp. p. 167 ff.; Bartelink, op. cit., p. 137 f.; HoppenBROUWERS, op. cit., p. $41 \mathrm{ff}$.

Col. 3, 17.

- Cf. Brou, Les oraisons dominicales, p. 25.

- Haessly, op. cit., p. 127 f.

5 Cf. p. 25.

- Cf. Einar Löpstedt, Coniectanea. Untersuchungen auf dem Gebiete der antiken und mittelalterlichen Latinitat, I, Stockholm 1950, p. 42 f. 
367. Here the people of God are visualized as being considered "vine yards" or "harvests" in His sight.

Novus, new, supernatural'1.

One of the deepest convictions of the Early Christians and one which was the source of boundless of enthusiasm was that they had received

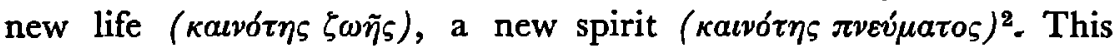
complete "otherness" of the life of a person once he was drawn into the mystery of Redemption was conceived by St. Paul in a free spiritual sense; and the term katvós came early to be connected with Baptism which is the means of initiation into this new life. We would expect, then, to find this term in the prayer for the blessing of the font: ad recreandos novos populos, quos tibi fons baptismatis parturit, spiritum adoptionis emitte, 754. Noous is always joined to some word or words which have reference to off-spring. In the prayer for the catechumens is the phrase: qui Ecclesiam tuam novo semper prole foecundas, 777. The collect for Fer. III infra Oct. Pasch. calls the neophytes a novus foetus: qui Ecclesiam tuam novo semper foetu multiplicas, 334; and in that of Sabb. Sant.: nova progenies, 346.

When, however, novus is applied to Nativitas, its meaning is "new" in the sense of "miraculous, supernatural". St. Leo expresses it thus: Nova autem nativitate genitus, conceptus a virgine, natus ex virgine sine paternae carnis concupiscentia sine maternae integritas iniuria ${ }^{3}$. It has this sense in the secret for the third Mass of Christmas: Oblata... munera nova Unigeniti Nativitate sanctifica, 723. Artistically it forms a fine antithesis to vetustas in the collect for the third Christmas Mass: ut nos Unigeniti tui nova per carnem Nativitas liberet; quos sub peccati jugo vetusta servitus tenet, 131 ; and in the second collect for Sab. Quat. Temp. Adv.: ut, qui sub peccati jugo ex vetusta servitute deprimimur; exspectata unigeniti Filii tui nova nativitate liberemur, 139. But when it modifies lux in the collect for the second Mass of Christmas it has the earlier meaning discussed above: qui nova incarnati Verbi tui luce perfundimur, 176.

Novitas, newness.

With a succinctness which is exceptional even in the oratrons, the prayer over the people for Fer. III Maj. Hebd. conveys the concept of the "newness of life" which is the essence of Christianity: Tua nos misericordia ab omni subreptione vetustatis expurget, et capaces sanctae novitatis efficiat, 1149. Its meaning is very close to the Late Latin profane word

1 K. Prümm, Christentum als Neuheitserlebnis, Freiburg 1939, passim; von Harnack, Terminologie der Wiedergeburt, p. $101 \mathrm{f}$.

Rom. 6.4; 7, 6.

- Sermo 22, 2. 
for newness (except for the fact that continency is regarded as a Christian virtue) in: refloreat cor et caro... castimoniae novitate, 484 . About its meaning in the postcommunion of the second Mass for Christmas: Hujus nos... sacramenti novites natalis semper instauret: cujus Nativitas singularis humanam repulit vetustatem, 631 , much has been written. That novitas belongs in the text as the antithesis of vetustas seems obvious ${ }^{1}$. It seems that it means "newness" in the sense of "ever-recurring", and the idea of the celebration of the Birth of Christ lies in the words natalis and sacramenti2.

OPUS (OPERA), good works ${ }^{3}$.

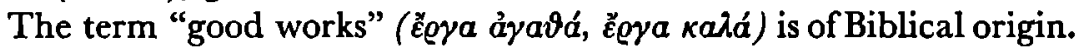
Found chiefly in the plural, it was applied in Scripture to all good works; but in Christian literature it came to be restricted, more or less, to works of practical Christian charity. As such it was regularly used in the following combinations, bona opera, opera justitiae, opera misericordiae, opera pietatis. Of these, only the first is found in the orations. Thus it occurs in prayers in Lent: ut, bonis operibus inhaerendo... mereatur... defendi, 184; quod a te obtinere abstinendo nititur, hoc bonis operibus exsequatur, 327; qui per abstinentiam macerantur in corpore, per fructum boni operis reficiantur in mente, 468; where, in view of the heavy accent laid by the Church of Rome, on alms in connection with the Lenten fast, we may conclude to the more limited interpretation of opera as "works of practical charity"4.

1 Cf. Odo Casel, Die "Neuheit" in den Weihnachtsorationen, LZ 4, 1931, P. 83 ff.; La "nova nativitas" dans les oraisons de la Noël, QLP 17, 1932, p. 285 ff.; Hans LIETzman,, Das Sacramentarium Gregorianum nach dem Aachener Urexemplar, Münster in Westf. 1921, p. xuxi-xxxii ; G. MoRı, Une énigme liturgique. La postcommunion de Noël à l'aurore, RB 47, 1935, p. 170 ff.; B. CAPELle, La postcommunion de la seconde messe de Noël, QLP 22, 1937, p. 298 ff.; Walter Diezinger, Effectus in der römischen Liturgie. Eine kultsprachliche Untersuchung, Bonn 1961, p. $123 \mathrm{fr}$. It is obvious that there is an error in the text as it stands in the MR today. But the above-mentioned scholars are far from being at one in their solution. As a matter of fact, either suggested solution involves emendations of the text, and none is wholly satisfactory. It seems to us that we must simply honestly say with Dom Morin that it is an enigma, and, until some further discovery of manuscripts may throw new light upon the subject, submit ourselves to the realization that the emendations are but suppositions.

2 Diezinger, op. cit., p. 133 quotes texts of St. Leo in which sacramentum means "the mystery of the Incarnation" or "the Birth of Christ", e.g. hodie procul dubio ad spiritalem laetitiam copiosius incitamur, Nativitatis Dominicae sacramento nobis clarius coruscante, Sermo $28, \mathrm{I}$; Cum ergo ad intelligendum sacramentum Nativitatis Christi, qua de matre virgine est ortus accedimus, Sermo 27, 1.

s Cf. Janssen, op. cit., p. 217 ff.; G. Kofrmane, Geschichte des Kirchenlateins, I. Entstehung und Entwicklung des Kirchenlateins bis Augustinus-Hieronymus, Breslau 1879, p. 30 and 79; PÉtre, op. cit., p. 240 ff.

Cf. p. 182 note 3 ; Brou, Les oraisons dominicales, p. 74. 
It may have the broader interpretation in the collect for Dom. infra Oct. Nat.: ut in nomine dilecti Filii tui mereamur bonis operibus abundare, 761, especially since there is the allusion to Col. $3,17^{1}$. We may apply the broader meaning also to: ac bonis operibus jugiter praestet esse intentos, 1150. When in the prayer for peace, we find: Deus, a quo... justa sunt opera, 201, we recognize that justa opera has the Christian sense of "good works in general". This last sense is applicable also when the word occurs in the collective singular: ${ }^{2}$ hoc in nostro resplendeat opere, quod per fidem fulget in mente, 176; see also 235, 802. To be noted here is that the word is used independently, a fact which indicates that it is a technical term. Its meaning in the collect for Dom XXIV p. Pent.: ut divini operis fructum propensius exsequentes... remedia majora percipiant, 548 , depends on how we interpret divinus. Brou, basing his argument on a passage from St. Gregory, Hom. XIX, no. 2, maintains that fructum divini operis means the same as fructum boni operis. That is a possible interpretation, and fructus would have, then, the broader Christian meaning. But if divinum stands in the place of a subjective genitive, then opus has reference to God's action in regard to man. It has this meaning surely in the solemn prayer for the Church on Good Friday: custodi opera misericordiae tuae, 780 , where it refers primarily to the works God has accomplished in and through the Church. The well-known secret of Dom. IX p. Pent. has: quia, quoties hujus hostiae commemoratio celebratur, opus nostrae redemptionis exercetur, 120. It seems that opus can be interpreted either in the sacramental sense; viz., that through the working of the inner power of the sacrament the graces of Redemption are applied here and now ${ }^{3}$. According to this interpretation opus exercetur stands for the passive of operari. If we consider the Eucharist as the commemorative sacrifice by which we "show forth the Death of Christ until He comes", then opus nostrae redemptionis may mean that redemptive Passion and Death. The presence of nostrae, however, lends weight to the former interpretation. $^{4}$. Furthermore, the usual sense of redemptio in the orations

1 Cf. p. 42.

2 For a discussion of the collective singular in Christian authors see JANSSEN, op. cit., p. 223; Jos. Schrijnen-Chr. Mohrmann, Studien sur Syntax der Briefe des hl. Cyprian (I-II, Nijmegen 1936-1937), I, p. 48.

S C. discussion of redemptio, p. 53.

- Cf. Odo Cased, Beiträge zu römischen Orationen. Die Sekret vom 9. Sonntag nach Pfingsten im römischen Messbuch, JLW I l, 1931, p. 35 ff.; DiezINGER, op. cit., p. 137 ff. Casel sees the opus redemptionis nostree as the actual historical events of the life and especially of the Passion and Death of Christ made numerically present in the Eucharist. Diezinger refutes this. In fact, theologians, for the most part, do not subscribe to Casel's theory in its entirety. Cf., for example, CrPRIEN VAGgaginı, Initiation théologique à la liturgie, 
pleads strongly for the sacramental interpretation ${ }^{1}$.

PAssio, sufferings unto death, i.e., those of Christ and of the martyrs ${ }^{2}$.

This noun and the verb from which it is derived, even as the Greek $\pi a ́ \vartheta \vartheta^{\prime}, \pi a ́ \sigma \chi \varepsilon \iota v$ acquired, under the influence of Christianity, a rich technical sense which included the concept of death along with the sufferings of Christ and the martyrs. In the orations this connotation is maintained. In the first place the term is applied to the passion of Christ. This is not only seen as an historical event, but it is regarded as the source of Redemption per unigeniti Filii tui passionem liberemur, 868; qui peccati... mortem... Christi... passione solvisti, 1183; see also 192, 200, 760,1128 . The collect for the Annunciation mentions the passion as the means of achieving the glory of the resurrection: per passionem ejus et crucem, ad resurrectionis gloriam perducamur, 575. This prayer seems to distinguish between the passion and the death (crucem) : but it is evident that crucem was added not so much to limit the meaning of passio as rather to maintain a balanced phrase.

Passio is synonymous with martyrium when it is used in reference to those who shared, in that special way, in the passion of Christ. It is regarded as an accomplishment which demanded great courage and endurance: qui beatum... Martyrem tuum virtute constantiae in passione roborasti, 292, 400. That the word suggests the idea of victory is illustrated by its being referred to as: beata passio, 728; that which leads to glory: sicut illos passio gloriosos effecit, 1107; and that which creates a new bond of brotherhood: quos eadem fides et passio vere fecit esse germanos, 943 . And therefore, too, the anniversary of the passio is worthy of being publicly celebrated: cujus passione laetamur, 886, 834, 815.

The verb pati, curiously enough, never appears in this specifically Christian sense in the ORATIONs. Once it has the proper profane sense of "to permit": non ad judicium provenire patiaris, 95, and once "to suffer punishment": pro peccatis patimur, 406 . This is one more indication that a noun tends to become much more of a technical expression than does a verb. It also illustrates the technical nature of the vocabulary of the ORATIONS.

adapted from the Italian (Il senso teologico della Liturgia ${ }^{2}$, Roma 1958) by Philippe Rouillard, Bruges-Paris 1959, p. 79 ff.

1 Cf. p. 53.

2 Cr. Teeuwen, op. cit., p. 44; Janssen, op. cit., p. $147 \mathrm{ff}$; $171 \mathrm{ff}$; Chr. Mohrmann Etudes, 12, p. 210 ff.; Hoppengrouwers, op. cit., p. $46 \mathrm{ff}$. 
PAx, peace'.

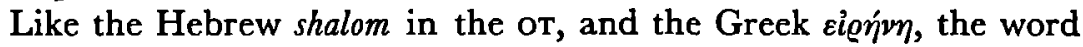
pax in Christian contexts has a deeply religious content. It is God who gives and actuates the peace. Though the word is employed somewhat as a cliché in the orations, still several of the basic Christian elements are clearly distinguishable. Even when the word corresponds to the proper profane sense of pax as "the absence of war", the context of the prayers brings it into relation with the moral concept included in the Christianism, as the postcommunion of the Mass for peace has it: Deus, auctor pacis et amator, quem nosse, vivere, cui servire, regnare est, 204; see also 463. God is regarded as the giver of peace: pax a tua pietate concessa, 318; da servis tuis illam, quam mundus dare non potest pacem, 201; Protege... famulos subsidiis pacis, 1184. Peace is also seen as Christian concord and hence is brought into relation with caritas: Deus, largitor pacis, et amator caritatis, 236; Deus, pacis, caritatisque amator et custos, 241 ; see also 434, 936. There is the petition for indulgentiam et pacis, 528, 661, 861, because forgiveness of sins is a prerequisite for "peace" with God. Only once does it occur in a specifically eschatological sense : $u$ t animam... in pacis ac lucis regione constituas, 644. Finally, it is used a few times unqualified, either in a request from God directly: pacem tuam nostris concede temporibus, $773 ; 264,527$; or as the effect of the sacramental action: sacramenta... proficiant ad prosperitatem et pacem, $474 ; 1144,559$, 698.

PIETAs, holiness, godliness; Divine mercy and goodness 2.

In profane Latin this noun had a strongly moral content, meaning the ideal of fidelity to one's duties to the gods, to one's country, to one's family and friends. In Christian Latin it was used to indicate the love and mercy of God toward men (as such it was synonymous with misericordia and clementia). It was employed especially as the name of the virtue practiced in regard to God; but it also designated the virtue of practical charity.

In the ORATIONs it occurs only three times as the virtue of man's attitude toward God. In the collect for Dom. XXII p. Pent.: adesto piis Ecclesiae tuae precibus, auctor ipse pietatis, 461 , it is, by reason of its being

1 Cf. W. S. van Leeuwen, Eirene in het Nieuwe Testament. Een semasiologische, exegetische bijdrage op grond van de Septuaginta en de Joodsche literatuur, Wageningen 1940, passim; Teeuwen, op. cit., p. 49 ff.; Mohrmann, Etudes, I², p. 28 ff.; PÉtré, op. cit., p. $46 \mathrm{ff}$.

2 Cf. C. Koch, art. Pietas, Pauly-Wissowa, 20, 1, p. 1222 ff.; PÉtré, op. cit., p. 251 ff.; W. DüRIG, Pietas Liturgica. Studien zum Frömmigkeitsbegriff und zur Gottesvorstellung der abendländischen Liturgie, Regensburg 1958, passim; B. Bотте, Pietos, in Bотте-МонRMANN, op. cit., p. $141 \mathrm{ff}$. 
set in relation to pius, to be understood as the state of soul which produces devout prayers. It is parallel and nearly synonymous with devotus in the collect for Fer. IV Cinerum: ut jejuniorum veneranda solemnia, et congrua pietate $^{1}$ suscipiant, et secura devotione percurrant, 833 . Since in the collect for Fer. Vinfra Oct. Pasch.: da nobis, et velle, et posse quae praecipis; ut populo... una sit fides mentium, et pietas actionum, 326 , there is a definite juxtaposition of fides mentium to pietas actionum; it is almost self-evident that there is intended a correlation of Faith and works. The text gives no indication that anything more than the Christian sense of pietas, "godliness", is here intended. Hence we cannot agree with Dürig when he interprets pietas actionum as "die kultische Feier des Opfermysteriums der Messe"2. In the Gel. Vetus this prayer appears in the Easter Vigil after the reading of Exodus VIII ${ }^{3}$, and hence has no direct connection with the Eucharist. Furthermore, the parallelism quoted above follows, in the same prayer, the phrase: da nobis, et velle, et posse quae praecipis. This also contains the contrast between the inner attitude of will and the realizing of that attitude in action. Stylistically fides mentium corresponds to velle, and pietas actionum to posse. Finally the general usage of actio in the sacramentaries does not impose the cultic interpretation. ${ }^{4}$

Although in the usual Christian language the word pietas was most frequently used of man's attitude toward God, this is just the opposite of what we find in the orations. In his study, Jeûne et Charité dans la liturgie du carême, Guillaume has pointed out that in the sermons of St. Leo the word pietas is employed as an attribute of God but seven times, while it is used 53 times of the moral attitude of the Christian ${ }^{5}$. In the ORATIONs, on the contrary, we find the word used 27 times of God's mercy and goodness to man, against the three times that it is used of man's attitude toward God. The reason for this vast difference is undoubtedly the influence of the court style on the language of the official euchology. This is most clearly seen in such examples as: pax a tua pietate concessa, 318 ; si tuae sint placita pietati, 562 ; dono tuae pietatis semper utamur, 791 ; aures tuae pietatis accomodes, 941 ; pietati tuae nos reddat acceptos, 1031 ; for in these, the abstract is used for the concrete, and pietas is almost a title of address ${ }^{6}$. For the most part the sense is quite broad

\footnotetext{
1 A. Gulllacme, Jeune et charité dans la liturgie du carême, NRTh 76, 1954, p. 248, interprets pietar here as "practical charity".

2 Cf. Dürig, Pietas liturgica, p. 53.

3 Mohlaerg, 439.

- Cf. actio, p. $91 \mathrm{ff}$.

s NRTh 76, 1954, p. 248; cf. also his Jeune et Charite, Paris 1954, p. $66 \mathrm{ff}$.

- Cf. O'Brien, op. cit., p. $19 \mathrm{ff}$.
} 
and general as in: Familiam... continua pietate custodi, 557, 558; or pietatis studio, quae sunt nutrita, custodias, 467. At other times it is identified with "mercy" by being brought into relation with the forgiveness of sins: pro tua pietate relaxa peccata, 756; or its specific character is emphasized by its being juxtaposed to majestas: ut digna sint munera, quae oculis majestatis offerimus, subsidium nobis tuae pietatis impende, 530.

PIUs, gracious, merciful; holy, loving 1 .

This adjective as applied to God means the same as misericors or clemens. But unlike the usage of the noun pietas, it is used only four times to refer to God's merciful attitude toward His people: pio favore, 936, 1179; pium auditum, 1046; pia miseratione, 414. The remaining 24 instances, in which pius does not refer to God, display several shades of meaning. When it is used in the expression: per haec piae placationis officia, 606, 906, 1031, its signification seems to stem from its pagan sacral use in the sense of "sacred, holy". It may be so interpreted also when there is question of pia munera, 919 , or pia solemnitas, 1059, or per haec piae devotionis officia, 1106. When devotio expresses a subjective attitude toward God, then pius adds the further nuance of "reverence", for example in: et gratiam nobis piae devotionis obtineat, 132; see also 150, 543, 846, 898. The prayer of the Christian is called pia petitio, 264; piae preces, 461 ; pia deprecatio, 794 . Christian moral living is also characterized as pius, "holy": piae conversationis sequamur exemplo, 399; piae conversationis augmentum, 989. This adjective is applied to the help and intercession of the saints, where it has the sense of "loving, kind": pia intercessio, 76; pia supplicatio, 167, 567; pia oratio, 1057; pium auxilium, 77. It also describes our love for the saints: quorum hic reliquias pio amore complectimur, 339. In fine, we may say that in the ORATIONs pius exhibits a much more general character than does the noun pietas. It characterizes God's relation to man, and especially man's relation to God and to his fellowman.

PLEBs, the people of God, the body of Christians'.

This is one of the earliest Latin designations for the people of God

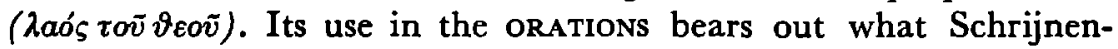
Mohrmann have asserted, namely, that the word in Christian usage was drawn from the profane neutral sense of "people" and does not indicate any social distinction between the clergy and the laity. Noteworthy, too, is that it occurs always in the singular, even though in later Early Christian Latin the plural became more usual. The

1 Cf. p. 47, note 2.

2 Cf. Janssen, op. cit., p. 55; Schrujnen-Mohrmann, op. cit., I, p. 59 ff. 
singular may represent an archaism employed for the sake of style, or it may be employed to emphasize the unity of Christian community. That it is a technical term is evidenced by the fact that it is, for the most part, used unmodified, except for the pronominal adjective tua which stands in the place of the Greek $\tau o \tilde{v} \vartheta \varepsilon o \tilde{v}$, or the Latin, Dei: $:^{1}$ plebis tuae dona, 57; concede plebi tuae piae petitionis effectum, 264; see also 524, 525, $526,539,616,700$. Tuus does not appear when another adjective is present. Thus in the solemn prayer for the Pope on Good Friday, we find christiana plebs, 757. The emphasis seems to be shifted to the adjectival modifier and the cultic aspect of plebs is stressed in such phrases as: Accepta tibi sit... sacratae plebis oblatio, 13; and, preces et hostias dicatae tibi plebis, 318, 8982.

POENITENTIA, conversion, contrition, penitence ${ }^{3}$.

Already in the translations of the NT this word was used to convey the

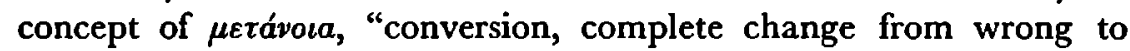
right". It was used for the first conversion which took place at Baptism, as well as for the repentance of sins committed after Baptism. It occurs but three times in the orations. That it means an internal attitude rather than an exterior form of penance is clearly expressed in the collect of the Mass, pro vitanda mortalitate: Deus, qui non mortem, sed poenitentiam desideras peccatorum: populum tuum ad te revertentem propitius respice, 395. The same depth of meaning is included in the phrase: per poenitentiam... placaris, 414, 319; and if we render it in English by "penitence" rather than "penance", it is because the former better emphasizes the inner aspect.

POENTERE, to repent, to convert, to change one's way of life.

Matzkow has pointed out that the Vetus Latina and Vulgata render the verb $\mu \varepsilon \tau a v o \varepsilon i v$ by poenitere, poeniteri, poenitet me, poenitentiam agere (habere, gerere), misereri ${ }^{4}$. This verb occurs but twice in the orations: in the postcommunion for public penitents: qui omnem animam poenitentem et confitentem tibi, magis vis emendare, quam perdere, 749 ; and in the blessing of the ashes: parce poenitentibus, 769 . The low frequency of these two words is partially to be explained by the fact that the terms were used for

1 WILHELM Havers, Das indogermanische Enklisengesetz in den Orationen des Missale Romanum, Kultur und Sprache, Wien 1952, p. 397 ff., esp. p. 401 ff., gives numerous examples to show that the insertion of pronouns, short adjectives, or other unaccented words after a word of more importance serves to accent the latter, and he maintains that this is one with a general Indo-Germanic law of enclitics.

- Cf. sacrare, p. $144 \mathrm{ff}$., and dicare, p. $138 \mathrm{ff}$.

3 Cf. Matzkow, op. cit., p. 132; Bartelink, op. cit., p. 132; Ysebaert, op. cit., p. 319 ff.

4 Op. cit., p. $30 \mathrm{f}$. 
conversion from grave sin; a conversion which included, therefore, a return to the fellowship of grace and the Christian community. They were not applied to what we call the "penance of Lent".

PONTIFEX; see PAGAN ROMAN RELIGIOUS TERMS, P. 140.

POPULus, the people of God, the Christian congregation ${ }^{1}$.

The Biblical expression "people of God" ( $\lambda a o ́ s \tau o \tilde{v} \vartheta \varepsilon o \tilde{)}$ ) was applied very early to the Christian congregation. Populus, a native Roman though already in the third century a very general and non-political term - became one of the technical Christian words for "the community of the faithful assembled for cultic purposes". It is in this sense that it is very prolific in the orATIONs. It is used in all but 12 of the \pm 61 instances in the singular and usually unmodified except by the pronominal adjective tuus. The employment of the plural largely represents the usage of the current language which made its way into the liturgical vocabulary: Absolve... tuorum delicta populorum, 7; see also 342, 367, 436, 1136,432 . Sometimes populus is modified by descriptive adjectives which characterize the "people of God": populus fidelis, 82, 180, 1115; populus christianus, 848, 182; populus tibi serviens, 166; subjectus tibi populus, 1070; populo ad aeternitatem vocato, 326 . In two of the prayers the meaning is limited to the neophytes: ad recreandos novos populos, 754 ; devotionem populi renascentis, 803. In the secret for peace: qui credentes in te populos nullis sinis concuti terroribus, 318, populos refers to "Christian nations". It is applied to the people of the OT in the prayers after the II and IV prophecy respectively during the Easter Vigil: quod uni populo, a persecutione Aegyptiaca liberando, dexterae tuae potentia contulisti, 211 ; qui per... Moysen... ita erudire populum tuum sacri carminis tui decantatione voluisti, 205. And finally, its meaning is restricted specifically to the Jews in the prayer for them on Good Friday: illius populi obcaecatione, 778. Here it has the very general profane sense.

PRAEDICARE, to preach the Gospel.

This verb, which in the language of the Early Christians, had the technical meaning of "to announce the message of salvation" ( $\left.\kappa \eta v^{\prime} \sigma \sigma \varepsilon \iota v\right)^{2}$ is used only once in this sense in the orations, namely, in the collect for the Feast of St. Bartholomew: et amare quod credidit, et praedicare quod docuit, 782. Note that docere is used of the action of the apostle, while praedicare is ascribed to the Ecclesia. This may be simply a stylistic device, since the latter rimes with amare, but it also expresses the 1 Cf. Janssen, op. cit., p. 58 f., 66 ff.; Schrijnen-Mohrmann, op. cit., I, p. 58 ff.

2 Cf. Bartelink, op. cit.; Chr. Mohrmann, Praedicare-Tractare-Sermo, Etudes, II, p. 63 ff.; Bastiaensen, op. cit., p. 96 f.; RenÉ Braun, op. cit., p. 430 ff. 
notion that the Church carries on the task of bringing the Word of God to men. In: sicut in Apostolo tuo Petro te mirabilem praedicamus, 659, it is used for "to praise" in a religious sense. This connotation, derived from the proper profane meaning of praedicare, reappeared in Christian authors in the fourth century.

PRAedicatio, the preaching of the Gospel.

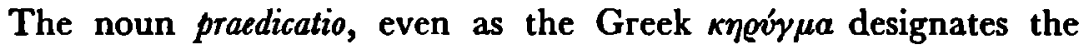
"transmission of the Word of God to man". It contains two essential elements, namely, that it is the preaching of the "Glad Tidings", and that it is the doctrine which the apostles have transmitted to the Church. Braun puts it thus: "ce mot désigne l'activité par laquelle les apôtres et leurs successeurs adressent aux hommes la Parole de Dieu, ou le contenu même de cette prédication"1. Although this word occurs but four times in the orAtions, it displays a very rich meaning. It is used only on the feasts of Ss. Mark, Matthew, and Paul, thus the apostolic element is retained. The preaching of St. Paul is seen as the means whereby God transmitted His Word to the world: Deus, qui universum mundum beati Pauli Apostoli praedicatione docuisti, 459. Then, too, something of the charismatic nature of the word ${ }^{2}$ is emphasized by the addition of the adjective magnificus, in the secret for the feast of St. Matthew: cujus magnificis praedicationibus eruditur, 1096. Because it is the transmission of the Word of God, praedicatio is also called a grace: Deus, qui beatum Marcum Evangelistam tuum evangelicae praedicationis gratia sublimasti, 297; and it leads to glory: sicut illum praedicatio evangelica fecit gloriosum, 74. It does not occur in the sense of "prophecy", nor in the later-developed sense of "sermon"3. The nomen auctoris also appears once with the full weight of its Early Christian connotation: Ecclesiae tuae beatus Andreas... extitit praedicator et rector, 670 .

REDEMPTIO, spiritual deliverance by God through Christ, Redemption 4 .

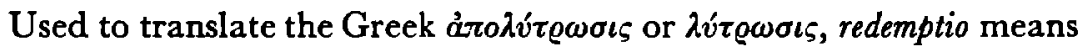
much more than legal redemption or liberation. It represents the real act of freedom from sin and a positive state of liberation. But it includes even more. By reason of its being a linguistic "calque", it hasinherited the Biblical nuances of its predecessor. And thus it has come to include both

1 Rent Braun, op. cit., p. 433 ; cf. also $430 \mathrm{ff}$.

2. Cohruann, Etudes, II, p. $66 \mathrm{ff}$.

3 Cf. Mohrmann, Etudes, II, p. 68.

- Cf. S. Lyonnet, De notione redemptionis, Verbum Domini 36, 1958, p. 129 ff.; ReNE

Braun, op. cit., p. 506 ff., esp. 511 . 
the negative idea of liberation from sin and the positive notion of union with God. Just as Israel became the special possession of Jahweh because she was ransomed by Him, so the purpose of the New Alliance is to bring mankind into contact with God. This liberation from sin and contact with God is accomplished in the cult, as the Epistle to the Hebrews has it: "Christ... by His own blood entered once into the Holies, having obtained an eternal redemption"1. The cultic connotation which is evident in the Epistle text is apparent also in the ORATIONs: Benedictio tua, Domine, ... munera nostra... nobis sacramentum redemptionis efficiat, 80; quoties hujus hostiae commemoratio celebratur, opus nostrae redemptionis exercetur, 120; quod pia devotione gerimus, certa redemptione capiamus, 150; Per haec veniat... sacramenta nostrae redemptionis effectus, 812; redemptionis effectum... capiamus, 958. The Eucharist is called pignus redemptionis, 1082, and munus redemptionis, 1091, and it leads ad redemptionis... augmentum, 1087. These texts make it clear that redemptio is not the historical Sacrifice of the Cross extended and made numerically present in the Eucharistic Sacrifice ${ }^{2}$. It is rather the sacramental effect of the cultic action (whether that action be expressed as commemoratio celebratur, by quod gerimus, or by some other phrase) ${ }^{3}$. What we, in more abstract terminology, would call the "graces which flow from the Work of Redemption", the liturgy expresses with its characteristic concreteness as redemptio. How aptly then, does the postcommunion for Fer. $V$ infra Oct. Pasch. express the essence of the Eucharistic action by calling it the: redemptionis nostrae sacrosancta commercia, 531 , from which are requested two effects: ut... et vitae nobis conferant praesentis auxilium, et gaudia sempiterna concilient.

The word redemptio has also an eschatological content. This we find, for example in the postcommunion of the first Mass on All Souls' Day: ut eas (animas) et a peccatis omnibus exuas, et tuae redemptionis facias esse participes, 52; see also 210,405, 955. The word is applied in a very broad general sense in reference to Christmas, because in the Birth of Christ the whole work of Redemption is in a sense contained. In the collect for the vigil of Christmas we have: qui nos redemptionis nostrae annua exspectatione laetificas, 410; and the collect for Ember Wednesday of Advent: ut redemptionis nostrae ventura solemnitas, 874. Once the term is used in a narrower sense of "forgiveness of sins": pro redemptione peccatorum 769.

1 Hebr. 9, 12; cf, also Eph. 1, 7 and 14; Rom. 3, 24.

2 Cf. p. 45 , note 4.

3 Cf. Diezinger, op. cit., p. 136 ff.; Herz, op. cit., p. 290 f. 
REDEMPTOR, Redeemer ${ }^{1}$.

This noun is used in the technical sense of Christ as our Redeemer: Unigenitum tuum Redemptorem nostrum ad caelos ascendisse, 136; 410. Its meaning is more general in: Fidelium, Deus, omnium conditor et redemptor, $567^{2}$.

\section{REDIMERE, to redeem.}

We have a clear statement of the fact that the state of man as redeemed is superior to his primitive condition in the prayer after the first prophecy in the Paschal Vigil: Deus, qui mirabiliter creasti hominem, et mirabilius redemisti, 385. Once redimere is used in the eschatological sense in a postcommunion for the departed: in tuorum sede laetantium constituas redemptorum, 1097. In the relative frequency of redemptio and redimere, we have evidence once again that nouns tend to become technical sooner than do verbs; and also of the fact that the vocabulary of the ORATIONs is quite technical.

RENASCI, to be reborn spiritually ${ }^{3}$.

Christianity was regarded as a re-birth, and terms for this phenomenon very early came to be applied to the effect of Baptism. So we have it in: ut renati fonte baptismatis, 777. That its perfect participle was used as a noun unmodified shows how technical it was: quas et pro renatorum expiatione peccati deferimus, 618 . Though at first sight its use in the collect for the Vigil of Pentecost: qui per gratiam tuam renati sunt, 854, may seem to be more general; still when we consider that this was one of the days on which the Sacrament of Baptism was administered, then we realize that here, too, it has the technical sense, gratia being used for "Baptism".

SAGERDOS; STe PAGAN ROMAN RELIGIOUS TERMS, p. 148.

SAECULUM, the present life as distinguished from eternity; times".

In Biblical language this word (aî $\omega v$ ), had a pejorative sense, as well as the neutral meaning, "this world" as opposed to the life after death. It is in this last sense that it is, for the most part, used in the ORATIONs in Masses for the departed, for example: quam (animam) de hujus saeculi eduxisti, 161. See also 208, 465, 644, 802, 844, 845-2, 1120. It is always modified by hoc or by praesens; thus, alone it is not a technical term. In: miracula etiam nostris saeculis coruscare sentimus, 211 , it has the

1 Cf. Blaise, Dictionnaire, p. 703; Mueller, op. cil., p. 103; RenÉ Braun, op. cit., p. $510 \mathrm{ff}$.

Cf. also Ps. 18, 15; Job 19, 25.

${ }^{3}$ Cf. Mohrmann, Sondersprache, p. 142; von Harnack, Terminologie der Wiedergeburt, p. $106 \mathrm{ff}$; Y Ysebaert, $o p$. cit., p. $141 \mathrm{ff}$.

Cf. Blarse, Dictionnaire, p. 732; Mueller, op. cit., p. 103. 
proper profane sense of "times". Saeculum does not appear in the special Christian sense of "the wicked world". To be mentioned here is the genitive of intensification: saecula saeculorum, which, though it is not written out in the prayers, still belongs essentially to them. This construction is native to the Indo-European languages; but here we may consider it as a Hebraism which came into the Latin prayers by

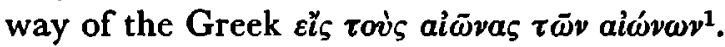

SALUs, Salvation².

It would seem unnecessary to quote all of the \pm 42 instances of this term. Laden with a number of nuances in profane Latin - physical health, well-being, welfare of the state - salus took on a completely new meaning in Christian Latin. However, it retained something of its polysemy.

In the first place, salus is applied to the spiritual redemption of mankind as such: pro salute generis humani signa tuae potentiae... ostendis, 380; quibus beatae Virginis partus exstitit salutis exordium, 559; see also 440. Under this general head is included also the notion of walking in viam salutis, 436, 856. Twice it is brought into relation with the remission of sins: ut omnium peccatis... deletis, quod denuntiatum est in ultionem, transeat in salutem, 205, ut indulgentiam nobis pariter conferant, et salutem, 626.

For the most part, salus is attributed to the sacramental action. Once it is the initial salvation brought by the sacrament of Baptism: id in salutem gentium per aquam regenerationis operaris, 211 . As is to be expected, the Eucharist is regarded as a means of salvation. In secrets and postcommunions we find the request that the oblationes, sacramenta, etc., proficiant ad salutem, 383, 616, 701, 831, 881, 897, 901; or proveniant ad salutem, 17, 623, 1019, prosit ad salutem, 1017; causa sit salutis, 104. The phrase ad salutem which had such a vigorously final sense in: ore autem confessio fit ad salutem, Rom. 10, 10, is in these prayers stylized and even somewhat trite. Note how it is used in the secret for the martyrs, Ss. Hippolytus and Cassian: et tuae testificatio veritatis nobis proficiat ad salutem, 978. The content is in these instances clear enough though. So, too, even when there is such a petition as: Da... salutem mentis et corporis, $184,312,406,689,897$, there is never any doubt that more than physical well-being is the object of the prayer; but such a petition does show

1 Cf. Schrijnen-Mohrmann, op. cit., I, p. 88; H. Sasse, art., aĭwo, in G. KrtTel, Theologisches Wörterbuch zum neuen Testament (Stuttgart 1933 ff.), I, p. $197 \mathrm{ff}$.

- Cf. Mohrmann, Etudes, I², p. 23, 90, 331; F. J. Dölger, Der Heiland, Antike und Christentum 6, 1950, p. 241 ff.; EujKenboom, op. cil., p. 16 ff.; RenÉ BraUn, op. cit., p. $478 \mathrm{ff}$. 
that man's nature as a whole is affected by "salvation". Note how well the collect for Dom. I p . Epiph. illustrates this; for after the request for "health" of mind and body it adds: ut ea, quae pro peccatis nostris patimur, the adjuoante vincamus, 406. The collect for travellers, too, has this combination of natural and supernatural in the word salus: et viam famulorum tuorum in salutis tuae prosperitate dispone, 30 .

It is seldom that salus has a medical connotation in the ORATIONs. There are the five instances mentioned above where there is a question of salus mentis et corporis. But more striking is the phrase: remedium... perpetuae salutis, 895,1157 , where we have an allusion to the páguaxov àvavarias ${ }^{1}$. This latter is at the same time an instance of the eschatological sense of salus. In the postcommunion for Fer. VI p. Dom. II Quadr.: accepto pignore salutis aeternae, 551, we have another. Once the term is identified with God Himself: Deus, salus aeterna, 804.

SAlutaris, Savior, as title for God ${ }^{2}$.

This term which was rare in pagan Latin was used beside Salvator by the Bible translators as a title for God. Though Lactantius says: Jesus, qui latine dicitur Salutaris, sive Salvator, quia cunctis gentibus salutifer venit $^{3}$, still in the ORATIONs Salutaris is used all four times of God: Adjuva nos, Deus salutaris noster, 41 ; see also $143,532,543$.

SERVIRE, to "serve" God".

The concept of man as a servant in relation to God is of Biblical origin. In the Vulgate servire and serous are the usual renderings for

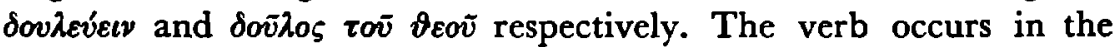
Orations in the moral religious sense some 14 times. Ordinarily the object is tibi, as for example: purificatis tibi mentibus servire mereamur, 542; see also $137,156,742,758,762,1168$. Once, however, mandata is its object: et tuis semper faciat servire mandatis, 1070. That this "service", of God is really an honor, is appropriately expressed by an oxymoron. Thus we have: tibi serviat libertate, $1 ; 517$; liberis tibi mentibus serviamus, 514, 912-2; and Deus... cui servire regnare est, 204.

Three times the verb is used in a cultic sense referring to the sacred rites: me... caelestibus mysteriis servire tribuisti, 743 ; ut digne tuis servire semper altaribus mereamur, 836; Protege nos... tuis mysteriis servientes, 918.

1 Cf. remedium, p. $186 \mathrm{f}$.

2 Cf. Mohrmann, VC 4, 1950, p. 230; Rene Braun, op. cil., p. 483 ff.; Fischer, ALW 1, 1950, p. $124 \mathrm{ff}$.

Inst. 4, 12, 6 .

- C.. Teeuwen, op. cit., p. 125; Bartelink, op. cit., p. 102; Lorit, op. cit., p. 78 ff., $83 \mathrm{fr}$. 
SERvus, servant of God, a Christian.

This noun which is so very frequent in the Vulgate ${ }^{1}$, occurs only twice in the ORATIONS: dirige ad te tuorum corda servorum, 235, in the prayer over the people for Fer. IV p. Dom. II Quadr.; and Non intres in judidium cum seroo tuo, 721, in the Absolutio super tumulum. Serous was, no doubt, considered too colloquial for the lofty language of the ORATIONs, and hence it was superseded by the more solemn, famulus ${ }^{2}$.

TEMPLUM, temple, house of God, church building ${ }^{3}$.

This noun which along with domus Dei was used to render the Greek oǐkos $\tau \circ \tilde{v} \vartheta \varepsilon o \tilde{v}$ was in earliest Christian Latin largely avoided by reason of its pagan connotations. It was, however, retained as a technical term for the temple of Jerusalem. In this latter sense it occurs twice in the ORATIONs, both times in prayers for the feast of the Presentation of Jesus in the temple, 765, 781. In three of the prayers for the dedication of a church the word templum is used for "the church building"4. But the word templum is in these instances by no means the technical designation of the material construction. It is a vital concept conveying the notion of "the place of living contact with God and the spot whence holiness has its source". Note how this finds expression in the following prayers: ut quicumque intra templi hujus,... ambitum continemur, plena tibi, atque perfecta... devotione placeamus, 55; templum hoc potentia tuae inhabitationis illustra, et concede; ut omnes, qui huc deprecaturi conveniunt... consolationis tuae beneficia consequantur, 380 ; Ut quisquis hoc templum beneficia petiturus ingreditur, cuncta se impetrasse laetetur, 392. This same richness of meaning is seen in the postcommunion for Dom. I Adv.: Suscipiamus... misericordiam tuam in medio templi tui, 1135, where Ps. 47, 10, is adapted to fit the prayer. Even more of the Early Christian metaphoric; viz., that the body of the Christian forms the living dwelling place for $\mathrm{God}^{5}$, is evident in the

1 Serous takes up 9 complete columns in F. P. Dutrupon, Concordantiae Bibliorum Sacronum Vulgalae editionis ad recognitionum jussu Sixti V Pontif. Max., Paris 1844.

Cf. famulus, p. 30.

"Cf. Chr. Mohrmann, "Domus Dei" chez saint Augustin, Etudes, II, p. 73 ff.; Revue des sciences religieuses 36, 1962, p. $154 \mathrm{ff}$; Y. Congar, Le mystere du temple. L'économie de la présence de Dieu à sa créature de la Genése à l'Apocalypse, Paris 1958, passim, esp. p. $166 \mathrm{fr}$.

- It is interesting to note that habitaculum is used twice, 321,439 , locus, is used once, 941 ; and domus, also once: super hanc orationis domum, 439 (cf. Mt. 21, 13). Domus is also used once in a context where it reflects the metaphoric of the body of the Faithful as a spiritual edifice: $A$ domo tua ... spiritales nequitiae repellantur, 3. Cf. MohrmanN, Revue des sciences religieuses $36,1962, \mathrm{p} .159 \mathrm{ff}$.

Cf. Jn. 2, 21; Col. 1, 18; Eph. 2, 22; 1 Tim. 3, 15; Hebr. 3, 6; 1 Peter 2, 5 and $4,17$. 
second collect for Fer. IV Quat. Temp. Pent.: templum nos gloriae suae dignanter inhabitando perficiat, 879.

The prayer for the blessing of candles - a prayer which first makes it appearance in the Lateran Missal ${ }^{1}$ - we find the expression: et sancto igne dulcissimae caritatis tuae succensi, in templo sancto gloriae tuae repraesentari mereamur, 781. Although the phrase is already somewhat of a cliché, templum has the eschatological sense here ${ }^{2}$.

VERBUM, the Word of God ${ }^{3}$.

This semantic "calque" for $\lambda o^{\prime} \gamma \sigma \varsigma \tau \sigma \tilde{v} \vartheta \varepsilon o \bar{v}$ appears in its technical sense twice in the ORATIONs: nova incarnati Verbi tui luce, 176; Verbum... carnem suscipere, 320. Sermo, the synonym for Verbum in the sense of "the Word of God", does not appear in the ORATIONS. In fact, it was almost entirely superseded by the latter by the middle of the fourth century ${ }^{4}$.

VETUSTAS, the condition of unredeemed man, sinfulness ${ }^{5}$.

René Dolle sums up the meaning of this word as follows: "Le mot vetustas est inspiré de saint Paul (Rom. 7,6) qui l'applique à la Loi ancienne déchue, attachée à la lettre, par opposition à la loi nouvelle inspirée par l'Esprit. Cette loi ancienne était une loi de mort qui 'agissait nos membres pour leur faire porter des fruits de mort'; c'est d'elle que relèvent les 'vices d'autrefois', donc le fidèle régénéré doit sans cesse se defaire"6. It is in this sense that it is used in the orations: ablato vetustatis errore, 200; cujus Nativitas singularis humanam repulit vetustatem, 631 , ab omni subreptione vetustatis expurget, 1149 ; a vetustate purgatos, 1160 . The adjective vetustus is used with the same meaning in the phrase: vetusta servitus, 131, 139. Finally we have: peccati veteris hereditariam mortem, 1183. Always the state of $\sin$ is represented as old in contrast to the newness of life brought by Christ.

visitatio, the coming of Christ?

One of the Latin translations for $\dot{\varepsilon} \pi i \delta \eta i^{\alpha}$ (which in turn is synony-

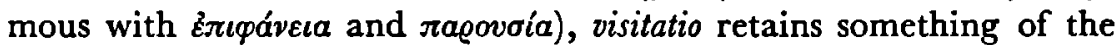
connotation, "the appearance of the $\delta \delta \xi a$ rov $\vartheta \varepsilon \sigma \tilde{v} "$ ". The light element

1 Cf. BruYlants, Les oraisons, II, p. 222, apparatus criticus.

- Cf. Congar, Le mystetre du temple, p. 257 ff.

a Cf. Blaise, Dictionnaite, p. 841 ; Mohrmann, Etudes, I², p. 167.

- Cf. RenE Braun, op. cit., p. 265 ff., esp. p. 266, where in note 1, he proposes that the elimination of Sermo for the Word of God, Christ, was facilitated by the generalization of that word for "sermon" (cf. MohrmanN, Etudes, II, p. 71).

B Cf. Blaise, Dictionnaire, p. 841; Mueller, op. cit., p. 131 ; Casel, QLP 17, p. 285 ff.

- Dolle, op. cit., II, p. 57 , note 3 .

7 Cf. Blarse, Dictionnaire, p. 852; Mohrmann, Etudes, I², p. 245 ff. 
of the "visitation" of the glory of God is ingeníously set down in the words of the collect for Dom. III Adv.: mentis nostrae tenebras, gratia tuae visitationis illustra, 64; where visitatio is not a genitive of source, but an appositional genitive ${ }^{1}$. Hence, together with gratic it represents the means whereby God is represented as "illuminating the darkness of our minds". This noun is seen not only as the coming of Christ, but also as an exercise of His divine power in the first and fifth collects for Sabb. Quat. Temp. Adv.: ex tua visitatione consolemur, 314; pietatis tuae visitatione consolemur, 887 . There may, too, have been another element which has played a contributing role in the use of this noun in the last two instances, namely, its medical sense, "visit", "examination"; this especially in view of the fact that consolare may mean "to help".

vita, life ${ }^{3}$.

This noun is another example of polysemy in the ORATIONs. When it has reference simply to life as "human existence on earth": inter omnes viae et vitae hujus varietatates, 30 ; vitae nostrae momenta, 219 , it is not a "Christianism" at all. Nor is its meaning specifically Christian when it is used in the moral sense of "manner of life": ut ad meliorem vitam Sanctorum... exempla nos provocent, 128; Da... indulgentiam peccatorum, consolationem vitae, 156; see also 213,290. But it is evident that in these latter instances the Christian ideal of morals is included.

However, vita is a genuine Christianism when it has the Johannine sense of $\zeta \omega \eta^{\prime}$, "supernatural life". Christ is called auctorem vitae, 440 ; and we pray: ut, per temporalem Filii tui mortem... vitam te nobis dedisse perpetuam confidamus, 662; de die in diem ad caelestis vitae transferat actionem, 727; qui non mortem peccatorum, sed vitam semper inquiris, 790; The eschatological sense of vita is evident in: ut ad vitam, una cum grege sibi credito, perveniat sempiternam, 239, etc., 448, 892, 1110.

Finally, there follow nine instances in which it is difficult to determine whether the vita praesens or vita temporalis means the ordinary human life, or whether it refers to the supernatural life on earth as distinguished from that life in its full unfolding in heaven. In each instance there is the request that the auxilium, subsidium, etc., be brought about as the effect of the sacred action of the liturgical celebration.

1 Cf. HaEssly, op. cit., p. 126.

2 H. Goenzer, Etude lexicographique et grammaticale de la latinite de saint Jerôme, Paris 1884, p. 258.

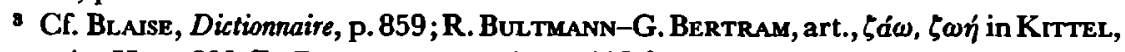
op. cit., II, p. $833 \mathrm{ff}$.; Bartelink, op. cit., p. $115 \mathrm{f}$. 
$u t$, quod est nobis in praesenti vita mysterium,

fiat aeternitatis auxilium (postc.) 107

ut et vitae nobis praesentis auxilium, et aeternitatis efficiant sacramentum. (secr.) 487

ut et temporalis vitae nos tribuas pace gaudere; et aeternae reperire subsidium. (or.) 527

et vitae nobis conferant praesentis auxilium, et gaudia sempiterna concilient. (postc.) 531

et praesentis nobis vitae subsidia conferat, et aeternae beatitudinis praemia largiatur. (or.) 874

ut et temporalis vitae nobis remedia praebeant, et aeternae (postc.) 1078

quod sit nobis... vitae praesentis auxilium pariter et futurae. (postc.) 1082

$u t$... et praesentis vitae nos conversatione sanctificent, et ad gaudia sempiterna perducant. (secr.) 1127

et praesentis... vitae

pariter et aeternae tribue conferre subsidium. (postc.) 1182

We have quoted these at length because it seems to us they illustrate two important phenomena of liturgical Latin. (a) Certain fixed expressions are repeated with slight changes in words or word-order. These expressions, because they are so familiar, evoke certain emotional responses, certain impressions, which it is almost impossible to define. (b) The language of the liturgy is frequently left very general, one might almost say ambiguous, so that it be capable of expressing the needs, the feelings, the spiritual aspirations of all present at the public and official worship. Thus, we think, that vita praesens must include both the natural and supernatural; for only then does it express what the life of a Christian de facto is.

VIVIFICARE, to cause to live supernaturally'.

This verb in -ficare was nearly always used in a spiritual sense by Christian writers. In the orations, too, it has the spiritual meaning of "to give new spiritual life", and it always refers to the effect produced by participation in the sacred food of the Eucharist: ut his muneribus...

1 Cf. Mohruann, Sondersprache, p. 211. 
et te placemus exhibitis, et nos vivificemur acceptis, 119; Oblatum tibi... sacrificium vivificet nos semper, et muniat, 734; Sancta tua nos... sumpta vivificent, 1027; Vivificet nos... participatio sancta mysterii, 1178.

\section{B. INDIRECT CHRISTIANISMS}

Under this head are included such words which, though they do not have a specifically Christian meaning, still are found in Christian texts, but not in profane authors. Since the orations stem from a period when the Christians no longer formed such a closed group, or, better said, from a period when the Christian group-language had become the ordinary vehicle of communication in the West, we cannot expect the indirect Christianisms to be very numerous. There are, however, a limited number of them.

BENEPLACITUM, liking, satisfaction'.

As a noun - a composite from bene + placitum ${ }^{2}$ - this word belongs to the liturgical rather than to the general Christian Latin ${ }^{3}$ : dirige actus nostros in beneplacito tuo, 761. The adjective, beneplacitus, "agreeable", is used in: beneplacitum tibi nostrae mentis offeramus affectum, 1121. Instead of the adjective as a composite, the Veronense always uses bene placitus ${ }^{4}$.

COAPTATIO, the effect of harmonious arrangement ${ }^{5}$.

This word, which appears for the first time in St. Hilary, is used here of the harmonious arrangement of the parts of a building in the familiar metaphor; viz., the Christians form a spiritual edifice for the dwelling of God:"6 ex omni coaptatione Sanctorum, aeternum condis habitaculum, 339.

CONGAUDERE, to enjoy together with another?

Ut populus christianus... temporali solemnitate congaudet, 848.

FIDUCIALITER, with confidence ${ }^{8}$.

This adverb found otherwise only in the Sacred Scripture and in Christian authors, is used in the orations, both times in the sense of "confidently": ut, praesentibus subsidiis sufficienter adjuti, sempiterna fiducialius appetamus, 229; ut pro peccatis nostris apud te fiducialiter intercedat, 692.

1 G. TLL II, p. 1890.

2 Cf. Goelzer, op. cit., p. 111, 131.

- Cf. Mohrmann, Sondersprache, p. 169.

- Mohlaerg, 1302, 1011, 1112, 1187, 1292.

5 Cf. TLL III, p. 1285; MohrmanN, Sondersprache, p. 212.

- Cf. Eph. 2, 20.

7 Cf. Mohrmann, Sondersprache, p. 173.

C. TLL VI, 1, p. 702. 
INGESSABILIS, constant, continuous ${ }^{1}$.

Palmas incessabili devotione venerari, 163; incessabili te gratiarum actione laudemus. 317.

INCESSANTER, constantly, continuously ${ }^{2}$.

Ut sancta tua, quibus incessanter explemur, 172; qui nostris excessibus incessanter affigimur, 868.

INDESINENTER, without ceasing, always ${ }^{3}$.

A propriis nos reatibus indesinenter expediat, 158.

INVISIBILITER, not visibly4.

Deus, qui invisibiliter omnia contines, et tamen pro salute generis humani signa tuae potentiae visibiliter ostendis, 380. The integral indirect Christianisms - invisibiliter and visibiliter - appear only in this ORATION.

RETRIBUTIO, payment, reward ${ }^{5}$.

Since the word was so frequently used to indicate punishment, the addition of beata was felt necessary here: et illum beata retributio comitetur, 1031.

TRIBUlatio, affliction'.

Formed in the popular speech after the model of the Greek $\vartheta$ Riwis, tribulatio means both physical and spiritual trials. It occurs five times in the ORATIONs: de tribulatione cognoscit auxilium, 13; ex quaqumque tribulatione ad te clamaverint, 380; continuis tribulationibus laborantem, 682; de quaqumque tribulatione clamantium, 766; Tribulationem... respice, 1142.

VERACITER, in reality, truly?.

This adverb has simply the profane meaning of "really", it has acquired a supernatural overtone only by reason of the context in which it is used: Caelestibus... pasti deliciis: quaesumus; ut semper eadem, per quae veraciter vivimus, appetamus, 97 ; ut caritatis donum... facias veraciter apprehendi, 397; ut effectibus nos eorum veraciter aptare digneris, 957.

VISIBILITER, visibly. See invisibiliter above.

1 Cf. TLL VII, p.887; Blaise, Dictionnaire, p. 422.

2 Cf. TLL VII, p 888; Blaise, Dictionnaire, p. 422.

3 Cf. TLL VI, 1137.

4 Cf. Mohrmann, Sondersprache, p. 215.

- Cf. Blaise, Dictionnaire, p. 722; Mohrmann, Sondersprache, p. 216.

- Cf. Mohrmann, Sondersprache, p. 210; Etudes, II, p. 121.

7 Cf. Mohrmann, Sondersprache, p. 217; A. ForCellin-V. DE VIT, Totius latinitatis lexicon (I-VI, Prati, 1858-1875), VI, p. 283. 


\section{SOME REMARKS ON THE DERIVED ADJECTIVE.}

The predilection for the use of a derived adjective with the weight of an adnominal genitive was prevalent in Early Christian writings ${ }^{\mathbf{1}}$. Studies have shown that certain fixed adjectives regularly recur in this function. Some of these are found in the orations also.

ANGELICUS, of the angels ${ }^{2}$.

Here we have one of the traditional adnominal adjectives molded into a rhetorical phrase which is characteristic of the ORATIONs: angelico pro nobis interveniente suffragio, 623.

APOSTOLICus, of an apostle ${ }^{3}$.

This adjective occurs in place of an adnominal genitive 5 times: apostolicae petrae soliditate (gen. of definition) $333 \mathrm{~b}$; apostolica... oratio (subj. genitive) 627-2; apostolica intercessione, 723-10; apostolicis intercessionibus, 953; apostolicae confessionis petra, 859.

Its use in: inter apostolicos Sacerdotes... famulos... fecisti... vigere, 375, shows a later development of the word, where it no longer has the value of an adnominal genitive but means "episcopal"4, in the sense that the bishop is a successor of the apostles. It is thus employed also by Paulinus of Nola, Epist. 3, 1, when he refers to the see of Tagaste in the words, in sede apostolica.

An interesting trend can be noted regarding this word. In 3 instances where apostolicus stood in some MSS, the genitive was either reinstated in later sources or introduced from another tradition. Thus beati Petri Apostoli ... oratio, 516, had been apostolica commendat oratio ${ }^{5}$ and Apostoli tui Jacobi... praesidiis, 524, had been apostolicis... praesidiis ${ }^{8}$; supplicationibus apostolicis beati Matthaei evangelistae, 1096, held its own until the second printed edition of the MR in $1604^{7}$ when the genitive apostoli replaced the adjective. In the expression: beatus Andreas apostolicus

1 Some of the bibliography on this subject is the following: Schrijnen, Charakteristik, p. 15, 42; Einar Löfstedt, Philologischer Kommentar zur Peregrinatio Aetheriae ${ }^{2}$, Uppsala 1936, p. 76 ff.; A. H. Salonrus, Vitae Patrum. Kritische Untersuchungen über Text, Syntax und Wortschatz der spätlateinischen Vitae patrum, Lund 1920, p. 179 ff.; SchriJNENMohrmann, op. cit., I, p. 89 ff.; Chr. Mohrmann, L'adjectif et le génitif adnominal dans le latin des chrétiens, Etudes, $\mathrm{I}^{2}$, p. 169 ff.; P. A. H. J. Merkx, Zur Syntax der Kasus und Tempora in den Traktalen des hl. Cyprian, Nijmegen 1939, p. 23 ff.

2 Cf. Mohrmann, Sondersprache, p. 79 f.; Etudes, I², p. 173.

${ }^{3}$ Cf. Mohrmann, Sondersprache, p. 82 ff.; Eludes, I², p. 173.

- Gf. Blaise, Dictionnaire, p. 89.

5 Vetonense, Mohlberg, 318.

- Ibid. 363.

7 In the Veronense, Monlberg, 1280, this secret appears on the feast of St. John 
exstitit praedicator ${ }^{1}$, the adjective has the value of a subjective genitive and has been replaced by an appositive: beatus Andreas Apostolus exstitit praedicator, 670 .

CAELESTIS, of heaven ${ }^{2}$.

This adjective is exceptionally prolific in the ORATIONs. Its usage ranges from the very traditional expressions as clavibus regni caelestis ${ }^{3}$, 280, to the fixed expressions referring to the Eucharist, which we shall treat shortly. There are phrases indicating "grace": caelesti dono, 448; caelestis gratia, 558, 559, 1283; caeleste auxilium, 381, 618, 880. There are moral concepts: caelestibus disciplinis, 143 ; caelestia desideria, 908 . Under this head come those cases where the neuter plural is used substantively: amare caelestia, 604, 970; in caelestibus habitemus, 136. The word has an eschatological connotation also: ad caelestia regna perducat, $630 ; 434$; caelesti sede gloriosa, 844; in caelesti regno, 1120; ad caelestum gloriam, 1106. But by far the most frequent usage of this adjective is in connection with participation in the Eucharist, usually - though not always - in postcommunions. Here we have such turns of speech as: caeleste donum (referring now specifically to the Eucharist), 95, 188, 514, 677, 1041, 1044, 1076; caeleste mysterium, 36, 169, 711, 949, 1065; caelestis benedictio, 104, 971, 972 ; caeleste sacramentum, 101, 106, 1075, 1087-3; caeleste munus, 107, 182, 955; caeleste remedium, 588, 703, 922, 1063; caelestia alimenta, 709, 945, 953; caelestibus deliciis, 97; caelestis virtus, 755; caelestis participatio, 916; caelesti cibo, 961 ; caelestis mensa, 1048, 1140 ; caelestis panis, 1069. Although it would seem that the frequency with which this adjective is used in reference to the sharing in the Eucharist has had its origin in the word of Christ: "This is the bread that has come down from Heaven", still the word panis occurs but once. Note how often the words connote the ritual element.

DIABOLICUS, of the devil4.

diabolica vitare contagia, 183; diabolica fraude deceptas, 799; contra diabolicos... incursus, 1148.

DIvinus, of Gods.

Here again we have an adjective which expresses an intrinsically

Evangelist. The Sacramentary of Prague, 192, 2, was the first to use it also for the feast of St. Matthew; cf. BRuYlants, Les oraisons, II, p. 319, apparatus criticus.

I Veronense, Mohlberg, 1234.

2 Cf. Schrijnen-Mohrmann, op. cit., I, p. 89; Merkx, op. cit., p. 29.

s The text of Mt. 16, 19 reads: Et tibi dabo claves regni caelorum.

- Cf. Mohrmann, Sondersprache, p. 99, 101 f.

6 Cf. Schrijnen-Mohrmann, op. cit., I, p. 90; Merkx, op. cit., p. 29 f. 
Christian concept. That it replaces the genitive $D e i$ is evident in such phrases as: gloriam divinae potentiae, 1064; divinae clementiae, 769; ignis ille divinus, 1004 ; divina caritate, 157; fructum divini operis, 548; divina subsidia, 639. Christ is called the divinae... generationis... auctor, 858. As was the case with caelestis, though far less frequently, this adjective is used to characterize the participation in the Eucharist: divina participatio, 947; divina sacramenta, 63, 590, 680, 687, 927; divina mysteria, 474, 1041, 1079; divina libatio, 996; divinum munus, 477 . The phrase: quae divina sunt is used once of the performance of the ritual act: ut quae divina sunt, jugiter exsequentes, donis mereamur caelestibus propinquare, 188; and once for the effect of that action: sic nobis haec terrena substantia conferat, quod divinum est, 698 .

Domincus, of the Lord'.

This adjective, so frequently used in Early Christian literature, is here restricted to two traditional expressions; viz., Dominicae Resurrectionis, 346 and 411 ; and Dominicae passionis, 760.

Ecclestasticus, of the Church².

ecclesiasticae pacis... tranquillitatem, 578. This same expression is used by St. Cyprian ${ }^{3}$.

Evangelicus, of the Gospel ${ }^{4}$.

This adjective is restricted to one fixed expression: evangelica praedicatio, 74 and 297.

FEMINEUS, of a woman'.

Femineo corpori, 434.

FRATERNUS, of the brothers ${ }^{6}$.

Fraterna nos... Martyrum tuorum corona laetificet, 570. This adjective in the collect of the Mass in honor of the Machabees may refer to the natural relation of blood brotherhood; but in the Gel. Vetus, this prayer was among the Orationes in natali plurimorum sanctorum. Item alia missa $(7 \mathrm{a})^{7}$, where it surely has the Early Christian meaning of "brothers in the Faith"'.

1 Cf. Schrijnen-Mohrmann, op. cit., I, p. 91 and 96; Mohrmann, Etudes, I', p. 91 ff.

2 Cf. Schrujnen-Mohrmann, op. cit., I, p. 93 ; Merkx, op. cit., p. 29.

Epist. 54, 1.

- Cf. note 2.

- Cf. Goelzer, op. cit., p. 151.

- Cf. Schrijnen-MohrmanN, op. cit., I, p. 94.

7 Mohlaerg, 1113.

- Cf. PÉtré, op. cit., p. 113 ff. 
HAERETICUS, of a heretic ${ }^{\text {. }}$

Omni haeretica pravitate deposita, 799.

ISRAELITICUS, of Israelites;

in Israeliticam dignitatem... transeat, 211.

PONTIFICALIs, of a bishop.

This adjective, used in classical Latin to mean "belonging to a pontifex", e.g. pontificalis auctoritas (Cic. Leg. 2, 211, 52) is used here as referring to the office of a bishop in the Catholic Church: pontificali... dignitate vigere, 375-3; pontificale... donasti meritum, 1120-6.

SACERDOTALIS, of a priest ${ }^{2}$.

This word has the general sense of "priestly", and even as the noun from which it is derived, it usually refers in the orations to a "bishop". Note that while the title of the secret has pro defuncto sacerdote and the text of the prayer in the MR have: cui sacerdotale donasti meritum, 1119, the text of the Gel. Vetus had: pontificale instead of sacerdotale ${ }^{3}$, thus indicating that the latter word had reference to a bishop. In: famulos tuos pontificali, seu sacerdotali fecisti dignitate vigere, 375; and pontificale seu sacerdotale donasti meritum, 1120, we have samples of prayers which made their appearance first in the eleventh century.

VIRILIs, of a man.

Ut femineo corpori de virili dares carne principium, 434.

AEgYPTIACUs, of Egypt ${ }^{4}$.

In addition to the above-mentioned adjectives, there is also this one formed from the geographical name, Egypt: a persecutione Aegyptiaca, 211. This rare adjective was first used by Gellius $(10,10,2)$, and is found, for the rest, almost exclusively in Christian authors.

1 Cr. Mohrmann, Sondersprache, p. 116.

2 Cf. Schrijnen-Mohrmann, op. cit., I, p. 94; Blaise, Dictionnaite, p. 729.

- Mohlaerg, 1635.

4 Cr. Schrujnen-Mohrmann, op. cit., I, p. 95 ff. 


\section{WORDS WHICH HAVE A TEGHNICAL LITURGICAL SENSE}

\section{A. WORDS WHICH HAVE REFERENCE TO THE EUGHARIST AS SUCH}

Although the orations do not form the central prayer of the Eucharistic Sacrifice, still they are an essential part of the rite as a whole, and they reveal in their language many aspects of the Eucharistic action. This is especially true of the secrets and the postcommunions. Hence it is only logical that we begin this chapter with an investigation of the words which refer to the Eucharist as such.

\section{Mysterium and Sacramentum}

These two nouns occupy a place apart in the Eucharistic terminology; hence we treat them alone in this section.

\section{MYSTERIUM}

It would obviously be out of place here for us to try to plumb the depths of the full theological content and to examine all the facets of this many-sided word ${ }^{1}$. Ours is a modest attempt to set down the philological facts regarding mysterium which appear in the ORATIONs.

The signification, "a revealed truth of Faith", which developed in Christian Latin from the general profane usage of mysterium $=$ secret or mystery ${ }^{2}$, occurs only once in the prayers under consideration, namely,

1 Some of the most important bibliography on this much-discussed subject is the

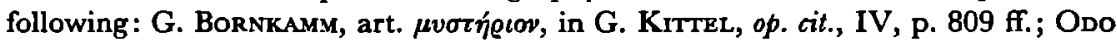
CAsel, Zur Kultsprache des hl. Paulus, JLW 1, 1950, p. 1 ff., with the bibliography there mentioned; Lours BouYer, La vie de la liturgie, Paris 1956, p. 113 ff.; I. H. Dalmass, Liturgie et mystère du salut, in A. G. MARTIMORT, L'Église en prière. Introduction à la liturgie, Paris 1961, p. 198 ff., esp. 205 ff.; G. FitTkau, Der Begriff des Mysteriums bei Johannes Chrysostomus. Eine Auseinandersetzung mit dem Begriff des "Kultmysteriums" in der Lehre Odo Casels, Bonn 1953, passim; MARIE BERnARD DE Soos, Le mystere liturgique d'apres saint Léon le Grand, Münster in Westf. 1958, passim; C. Couturier, "Sacramentum" et "mysterium" dans l'oeuvre de saint Augustin, in H. RondET-M. LE LANDais-A. LaurasC. Couturier, Études augustiniennes, Paris 1953, p. 161 ff.; D. Deden, Le mystere paulinien, Ephemerides theol. Lov. 13, 1936, p. $403 \mathrm{ff}$.

2 Cf. Chr. Mohrmann, Sacramentum dans les plus anciens textes chrétiens, Etudes, $I^{2}$, p. $235 \mathrm{ff}$. 
in the postcommunion for 13 Jan.: ${ }^{1}$ Caelesti lumine... semper et ubique nos praeveni: ut mysterium, cujus nos participes esse voluisti, et puro cernamus intuitu, et digno percipiamus affectu, 92. Here mysterium is both doctrinal and ritual - in so far as the Incarnation is a revealed truth, made known in the Epiphany, it is a mysterium which we desire puro cernamus intuitu; in as much as we are celebrating it in an efficacious rite, we ask that digno percipiamus affectu.

The whole cultic action of the Eucharist is concretely included in this word ${ }^{2}$. It may be in a very general way with no distinction between the outer ritual action and the inner grace as in: Quae sacris sunt oblata mysteriis, 26; or in: tua mysteria celebrantes, 1130. But there are instances in which the symbolism of the rite is clearly juxtaposed to its inner mysterious efficacy. The secret for Dom. II p. Pascha is a case in point: $u t$, quod agit mysterio, virtute perficiat, 81 ; as is also the postcommunion for Ascension: ut, quae visibilibus mysteriis sumenda percepimus, invisibili consequamur effectu, 84l. See also: ut, quod est nobis in praesenti vita mysterium, fiat aeternitatis auxilium, 107; ut illius salutaris capiamus effectum, cujus per haec mysteria pignus accepimus, 940; Quos tantis... largiris uti mysteriis... ut effectibus nos eorum veraciter aptare digneris, 957 . That such juxtaposition is something of a literary device used to enhance the style of these solemn prayers $^{3}$, and not designed primarily to indicate a sharp differentiation between the outward rite and the inner effect can be seen by the fact that the production of supernatural effects is sometimes ascribed to the rites themselves. The secret for Dom. VIII p. Pent. has: ut haec sacrosancta mysteria, gratiae tuae operante virtute sanctificent, et ad gaudia sempiterna perducant, 1127; the postcommunion for Dom. infra Oct. Nat.: Per hujus... operationem mysterii, et vitia nostra purgentur, et justa desideria compleantur, 813. See also 604, 1090. Then, too, God is requested to "work" through the mysteries: Sanctificationem tuam nobis... his mysteriis operare placatus, 1044; Tuis... operare mysteriis, 1161; Caelestibus nos munda mysteriis, 711. A particularly interesting group of texts which illustrate the meaning of mysterium as "the ritual action" of the Eucharist in as much as it is a symbol laden with divine efficacy, are the following postcommunions: Dom. I Pass. : quos tuis mysteriis recreasti, 33; that of Fer. VI inf. Oct. Pasch.: Respice... populum tuum; et quem aeternis dignatus es renovare mysteriis, 985 ;

1 Since the revision of 1960 , this postcom. appears in the MR, In Com. Bapt. D.N.J.C. However, in the Gel. Vetus, Mohlnerg, 67, it was used for the feast of Epiphany itself. 2 Though in the time of Caesarius of Arles, missae was the popular name for "the Mass", still divina mysteria was the more solemn designation for it. Cf. CHR. MoHrmann, Missa, VC 12, 1958, p. $76 \mathrm{ff}$., reference to p. 88.

3 Cf. Haessly, op. cit., passim. 
that of Dom. in Alb.: ut sacrosancta mysteria, quae pro reparationis nostra munimine contulisti, 928; and of Fer. III p. Dom. III Quadr.: Sacris... mysteriis expiati, 1020, 571. In all of these it has the full sacramental meaning.

There are some instances where the meaning of mysteria seems to be limited so as to refer specifically to the Sacred Species in the Communion rite. Such, for example, are the cases where it is used with the verb sumere: Sumpsimus... divina mysteria, 1079 ; sumpta... mysteria, 65,715 ; or replere: salutaribus repleti mysteriis, 930; or even libare ("to taste the first fruits of"): Divina libantes mysteria, 474. Surely mysterium means the Eucharistic food and drink in the postcommunion for the Vigil of Christmas: cujus caelesti mysterio pascimur et potamur, 169. And yet the very use of this noun to express what we today call "Holy Communion" shows how definitely the latter is an element of the sacred rite. Such phrases as: quos tanti mysterii tribuis esse participes, 2; hujus participatione mysterii, doceas nos terrena despicere, 970; Vivificet nos... hujus participatio sancta mysterii, 1178; in mysterii salutaris faciat transire consortium, 1160, also indicate the broader meaning of mysterium so as to include the whole ritual action.

What are the mysteria paschalia mentioned in the secret of Sabb. in Albis: Concede... semper nos per haec mysteria paschalia gratulari, 124; and in the secret of Sabb. Sanct.: ut paschalibus initiata mysteriis, ad aeternitatis nobis medelam, te operante, proficiant, 1131 ? The fact that this phrase occurs in the secret of the Easter Vigil, during which the various rites of initation were administered, might lead one to surmise that mysteria stands here for all of these rites. However, as B. Botte has pointed out ${ }^{1}$, nobis refers to the whole Christian congregation and not to the neophytes alone. Furthermore, ad aeternitatis nobis medelam is the type of effect frequently sought from the Eucharist ${ }^{2}$. Hence, it is safe to conclude with Botte $^{3}$ that "le mystère de Pâques est principalement le sacrificium paschale, le sacrifice du Christ, véritable Agneau paschal, sacrifice qui se renouvelle dans l'eucharistie". The mysteria paschalia are, then, the ritual acts of the Eucharist which marks the climax of the Paschal Solemnities.

In like manner, in the secret for Fer. IV Maj. Hebd.: ut, quod passionis ... mysterio gerimus, piis affectibus consequamur, 1128, mysterio represents concretely the Eucharistic action in which hic et nunc the Passion is reenacted. There is evident reference to 1 Cor. 11,26 in the postcom-

1 Cf. Botre, EL 61, 1947, p. 77 ff.

Cf. p. 183, and 186.

Ibid., p. 87. 
munion of the same Mass: per temporalem Filii tui mortem, quam mysteria veneranda testantur, 662. It is interesting to note that quam mysteria veneranda testantur - a typically ritual expression - replaces the: Quotiescumque enim manducabitis panem hunc et calicem bibetis: mortem Domini annuntiabitis donec veniat.

The celebration in memory of the Feast of the Nativity consists also primarily in the Eucharist: qui Nativitatem Domini nostri Jesu Christi mysteriis nos frequentare gaudemus, $164 ;$ Munera nostra... Nativitatis hodiernae mysteriis apta proveniant, 698 . So, too, it is the Eucharist which regularly constitutes the celebration in honor of the martyrs: Mysteria tua... pro sanctorum Martyrum tuorum honore devota mente tractemus, 716; ut sicut per haec beata mysteria illis gloriam contulisti; ita nobis indulgentiam largiaris, 650; ut sanctorum Martyrum tuorum... caelestibus mysteriis celebrata solemnitas, 949. It seems unnecessary to seek behind the word mysterium in these last-quoted examples any meaning other than "the Eucharist" as the act of cult which constitutes the essential element of a liturgical feast. However, we must admit that in the secret for the Christmas Mass (in Aurora), since the whole prayer is replete with allusions to the Feast of the Nativity", mysteriis could refer to the "liturgical mystery" in the sense in which St. Leo uses the term; viz., as a definite day of the year which is the anniversary of a major work of the Savior, a day on which all Christians assemble to celebrate the memory of that event by accomplishing the Eucharistic cult in the course of which the Sacred Readings recall the event commemorated 2 .

Mysterium occurs but twice in collects, both times in almost identical expressions and trains of thought. The collect of the first Mass of Christmas has: ut cujus lucis mysteria in terra cognovimus, ejus quoque gaudiis in caelo perfruamur, 347; that of the Feast of the Exaltation of the $\mathrm{H}$. Cross: ut, cujus mysterium in terra cognovimus, ejus redemptionis praemia in caelo mereamur, 405. In both instances cognovimus means more than "to know intellectually"s and mysterium more than "revealed truth". They both contain the idea of a real, effective experience of salvation, and

1 munera nostra... Nativitatis hodiemae mysteriis apta proveniant, et pacem nobis semper infundant: ut, sicut homo genitus idem refulsit et Deus, sic nobis haec terrena substantia conferat, quod divinum est.

Cf. DE Soos, op. ait., p. $43 \mathrm{ff}$.

a. Congar, Les voies du Dieu vivant. Théologie et vie spirituelle, Paris 1962, p. 83, says that the knowledge of God is not purely a matter of the intellect. "Elle est à la fois instruction et sainteté. Elle n'est pas une simple information préalable au salut, elle est déjà salut en acte. Saint Paul joint l'idée d'être sauvé et celle de parvenir à connaissance la vérité: qui omnes homines vult salvos fieri, et ad agnitionem veritatis venire (1 Tim., 2, 4)". 
thus too, the enjoyment of eternal happiness is seen, if not as the direct result of the mysterium, at least closely allied to it.

Finally, this noun appears a few times in reference to other sacraments. In the prayers for the blessing of the font it is synonymous with sacramentum, and both mean "the outward signs which are productive of the graces of the sacrament": adesto pietatis tuae mysteriis, adesto sacramentis, 754 ; ut fidei ipsius sitis, baptismatis mysterio animam, corpusque sanctificet, 803. It is by reason of its sacramental character that matrimony is a symbol of the union of Christ and the Church: Deus qui tam excellenti mysterio conjugalem copulam consecrasti, ut Christi et Ecclesiae sacramentum praesignares in foedere nuptiarum, 434 . Note that mysterium is used in this prayer for the "sacramental" element which God has granted to the nuptial union; while sacramentum is employed for what is called the $\mu v \sigma \tau$ joıv in the Greek text of St. Paul ${ }^{1}$. Thus the latter has here the meaning it had in profane Latin at the time that it was introduced into the Bible translations; viz., "sacred union"'. By means of the mysterium the ordinary foedus nuptiarum becomes a figure of, and thereby has a share in, the sacramentum (sacred union) of Christ and the church.

As to the relation between the use of the singular and the plural of mysterium, we may say that on the whole there is no essential difference in meaning between the two. The plural can, of course, be explained by the general rule according to which the names of feasts, rites, etc., are used in the plural. Hence, too, it is by far the more frequently used. The singular seems to be somewhat more vague and means "the sacramental action" in a rather general way; while the plural seems to be more concrete, and regards the sacramental rites as here and now in progress. It is curious to note that the genitive never appears in the plural, probably because it does not fit into the rhythmical pattern of these prayers.

To sum up, then, we may say that mysterium in the orations has a

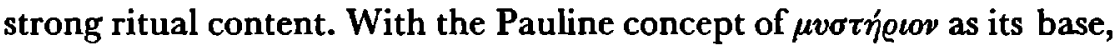
it is here applied, by limitation rather than by extension of meaning, specifically to the sacramental action of the Eucharist. In the few examples where it refers to Baptism or to Matrimony, it has also this sacramental connotation. Only once is there question of its meaning "revealed truth" and once there is the possibility that it refers to the "liturgical mystery" as a whole.

1 Eph. 5, 32; Col. 1, 27.

- Cf. Mohrmann, Etudes, I², p. 240. 


\section{SACRAMENTUM}

In general we may say that in the ORATIONs, as frequently in other Christian Latin works, the word sacramentum is almost synonymous with mysterium1. Since the former "suggère par son étymology même, qui jamais n'a été effacée, un élément sacramentel et liturgique"2, it would logically be expected - and it is actually the case - that sacramentum $(72 \mathrm{x})$ be used more frequently than mysterium $(57 \mathrm{x})$ in this part of the Church's euchology.

Only once does sacramentum appear with the meaning of "a revealed truth" - a connotation which it received by reason of the fact that when it was substituted for the Greek $\mu v \sigma \tau$ jotov, it took on the various nuances of this word. In the secret for the feast of the Annunciation we have: In mentibus nostris... verae fidei sacramenta confirma, 641 .

Various aspects of the ritual or "sacramental" sense of this word; viz., sacramentum as the "source of grace", or "the actualization of the economy of Salvation", are found. In the first place there is its meaning, "liturgical mystery" in a broad sense. Thus, in the secret for Ash Wednesday we are represented as celebrating by the Eucharist the beginning of the Paschal mystery, which is called the venerabile sacramentum: Quibus (muneribus) ipsius venerabilis sacramenti celebramus exordium, 554. The collect of Fer. VI p. Dom. IV Quadr. also refers to the whole Paschal celebration with this word: Deus, qui ineffabilibus mundum renovas sacramentis, 373. The liturgical celebration of the historical event of the Passion is clearly contained in the word sacramenta in the collect for Fer. III Maj. Hebd.: da nobis ita Dominicae passionis sacramenta peragere, 760. In the collect for Feria VI infra Oct. Pasch.: Deus, qui paschale sacramentum in reconciliationis humanae foedere contulisti, 793 , the paschale sacramentum could mean the liturgical celebration of the Festa Paschalia as a whole during which the reconciliation of mankind is sacramentally renewed, but it could also mean the historical events of the Passion and the Glorification. The second half of the prayer: da mentibus nostris: ut, quod professione celebramus imitemur effectu, lends weight to the latter interpretation. This same term paschale sacramentum is applied to the Eucharist as the essential cultic act of the Paschal celebration ${ }^{3}$. The postcommunion for Fer. III infra Oct. Pasch. has: paschalis perceptio sacramenti, 133;

1 Couturier, op. cit., p. $265 \mathrm{f}$. and $269 \mathrm{ff}$. has shown this to be the case in the works of St. Augistine also, with the exception that sacramentum appears with a slightly greater frequency in the ritual sense, while mysterium occurs more often as "revealed truth".

2 Cf. Mohrmann, Etudes, I’, p. 243.

S C. mysteria paschalia, p. 69. 
that of Easter has: quos sacramentis paschalibus satiasti, 1069. (Note that there is no apparent difference between the singular and the plural in the last two citations).

In Epistle $121 \mathrm{St}$. Leo has the phrase: paschale festum quo sacramentum salutis humanae continetur ${ }^{1}$. Here we have to do with the element of efficaciousness in the word sacramentum. So, too, when the Eucharist is called salutaria sacramenta or a near equivalent thereof, it is seen as the ritual act whereby the divine economy of salvation, the Pauline

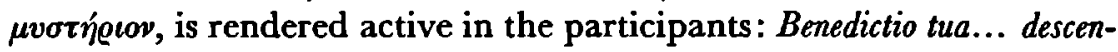
dat: quae et munera nostra... tibi reddat accepta, et nobis sacramentum redemptionis efficiat, 80. The secret for Fer. II p. Dom. III Quadr. gives, with remarkable clarity, expression to the request that the ritual act become effective of salvation: Munus, quod tibi... nostrae servitutis offerimus, tu salutare nobis perfice sacramentum, 713. Less strikingly perhaps, but nevertheless certainly, do the following enunciate the same idea: $u t$ haec salutaria sacramenta illis proficiant ad prosperitatem et pacem: pro quorum quarumque dilectione haec tuae obtulimus majestati, 474 ; per haec sacramenta salutis nostrae, cunctorum remissionem tribue peccatorum, 217.

That the word indicates "efficacious rites" is further illustrated by the fact that it occurs in expressions like: per hujus virtutem sacramenti, 877, 1133; Per haec veniat... sacramenta nostrae redemptionis effectus, 812; ut hic sacramentorum virtus... obtineatur effectus, 755 ; and Sit nobis... sacramenti tui certa salvatio, 1066. Sacramentum (sacramenta) is, then, the means by which the inner regeneration of the Christian soul is furthered: Deus, qui nos ad imaginem tuam sacramentis renovas et praeceptis, 397; Purifica... mentes nostras benignus, et renova caelestibus sacramentis, 920. See also 353, 680, 927, 997.

We may discern in the orations a tendency toward a further restriction of the meaning of the word sacramentum. More than 75 per cent of the instances of the use of this noun occur in postcommunions. Here the viewpoint is often that of something participated in rather than of something performed. Mark how frequently sacramentum is employed in conjunction with words meaning "to take nourishment" or "to nourish": perceptio sacramenti, 4, 133, 590, 630, 915, 1050, 1063, 1158; percipere, 814, 815; vegetare, 63, 719; libatio, 996, 1160 ; sumere, 121, 142, 749, 921, $922,923,932,991,1000,1075,1078 ;$ satiare, 1069 . The postcommunion for Ss. Hippolytus and Cassian: Sacramentorum tuorum... communio sumpta nos salvet, 1000, demands an extra word. It is one of the two instances where the genitive plural appears; and this lends weight to the suppo-

1 Epist. 121, 1, 13. 
sition that sacramentorum may here be subject to an additional limitation of meaning. St. Leo, when criticizing the Manicheans for their exaggerated rigor in regard to food and drink, says: ita in sacramentorum communione se temperant, ut interdum, ne penitus latere non possint, ore indigno Christi corpus accipiant, sanguinem autem redemptionis nostrae haurire omnino declinent ${ }^{1}$. He has: non sacramentorum tibi communio denegatur ${ }^{2}$ and qui te a corporis et sanguinis sui communione non repulit ${ }^{3}$, when speaking of Christ's conduct toward Judas. Since corporis and sanguinis are evidently included in sacramentorum in the first quotation, and since they are used with communio in the third in the same sense as sacramentorum is used in the second citation, we may be safe in saying that sacramentorum is plural because it means very specifically the two-fold species under which the Sacred Body and Blood were received. It would be plausible, then, to see in the genitive plural of No. 1000 a specific reference to the sacred species received.

However, that does not at all indicate that usually the meaning of sacramenta in postcommunions is so restricted. Quite the contrary is true. A postcommunion like that of Ss. Simon and Jude: Perceptis... sacramentis suppliciter exoramus: ut... quae pro illius veneranda gerimus passione, nobis proficiant ad medelam, 815; and that of Fer. IV Quat. Temp. Pent.: Sumentes... caelestia sacramenta, quaesumus... ut quod temporaliter gerimus, aeternis gaudiis consequamur, 1075, are just two examples which show that sacramentum ( $a$ ) has maintained an essentially ritual and cultic sense. There is no hint of the "modern" conception of Holy Communion as an individual personal reception of Jesus in the Blessed Sacrament.

Nor are we able to draw any conclusions as to meaning from a distinction between the singular and the plural. In the discussion of No. 1000 above we sought to justify, by limitation of meaning, the appearance of the genitive plural which is otherwise almost entirely avoided. But the evidence is not entirely conclusive, especially in view of the fact that the same explanation does not hold good for the other instance of the usage of sacramentorum: Deus, qui nos sacramentorum tuorum et participes efficis, et ministros, 748 , where the presence of ministros maintains the ritual content of the word. As for the rest, the singular or the plural are used without apparent distinction. Sometimes stylistic reasons are evident. For example, a definite seeking for rime led to the use of the singular in: Praesentium munerum et alimento vegetas, et renovas sacramento, 353. Again certain fixed expressions are noticeable; perceptio sacramenti

1 Sermo 42, 5.

- Sermo 58, 3.

3 Sermo 54, 3. 
is one such. In fact, all eight times that perceptio is used it is found with the objective genitive sacramenti.

There reamins a word to be said about the use of sacramentum for other sacraments. In the collect for Fer. III infra Oct. Pasch.: Deus, qui Ecclesiam tuam novo semper foetu multiplicas: concede famulis tuis: ut sacramentum vivendo teneant, quod fide perceperunt, 334, it means the work of salvation accomplished in the neophytes by Baptism. For its use in relation to the sacrament of Matrimony see p. 71 .

In summary we may say that though sacramentum reveals a tendency to be restricted to use in postcommunions, still it has a definite ritual content in the ORATIONS. Like mysterium it rarely means "revealed truth" or "figure". The idea of efficaciousness predominates to make it stand for the sacred rites in and through which God continues to work out the Economy of Salvation. It is used three times to mean the liturgical mystery in the broad sense, once for Baptism and once for the Greek $\mu v \sigma \tau$ ท́o reference to the Eucharist.

\section{Terms designating the gifts offered and the act of offering}

\section{HOSTLA}

In the sense of victima this word was a common term for sacrifice throughout all periods of Latinity. It is the usual word used in the Vulgate especially in the NT to translate $\vartheta v \sigma^{\prime} a^{1}$. Rheinfelder also mentions that the Epistle to the Hebrews employs it frequently in connection with

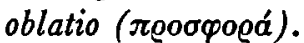

We would expect, then, to find hostia as one of the key words in the orations. And so indeed it is, for it occurs 43 times - always in secrets. We may consider "the gifts brought by the faithful" as the most obvious concrete meaning of the word. The secret of Dom. XII p. Pent.: Hostias quas sacris altaribus exhibemus, 619; and that of the Mass Os justi: sacris altaribus... hostias superpositas, 1019, bear this out. Its use with offerre, $615,620,623,624,627,1119,1120$; and with deferre, 53, 618, 621, 625, 626 point up this meaning also.

These gifts have a sacrificial character. The basic meaning of hostia as victim is never lost. We shall note elsewhere the frequency of the verb immolare in this connection ${ }^{2}$. The gifts are offered as the cultic act on the occasion of feasts: Hostias tibi... pro nati Filii tui apparitione deferimus, 625; Hostias tibi... pro sanctorum Martyrum... commemoratione deferimus,

1 Cf. TLL VI, p. 3045 ff.; RhenNfelder, Kultsprache, p. 257 f., 270.

Cf. p. 139 and p. 193. 
626; quae (hostia) in natalitiis sanctorum Martyrum... immolatur, 824. See also $627,664,896,1095$. They are offered together with preces ${ }^{1}$ to obtain a favor: suscipe preces et hostias famulorum tuorum, pro quibus aegrotantibus misericordiam tuam imploramus, 219; dignare preces et hostias... suscipere, ut pax a tua pietate concessa... fines ab omni hoste faciat esse securos, 318 . Finally, they are offered on behalf of the souls of the faithful departed: quas (hostias) tibi pro animabus famulorum famularumque tuarum offerimus, 620 , 892, 906, $1119,1120$.

That the word has a ritual, sacramental character is illustrated by such secrets as that for Dom. III p. Epiph.: Haec hostia emundet nostra delicta, 581; that for Dom. III Ado.: Devotionis nostrae tibi... hostia jugiter immoletur, 469; that for 29 Sept.: ut easdem (hostias)... ad salutem nostram provenire concedas, 623; and that for Ss. Martyribus, 30 Aug.: quas (hostias) in honore Sanctorum tuorum... celebrat, proficere sibi sentiat ad salutem, 616. The Eucharist (hostiae), i.e., the whole ritual, sacramental action, is designated as a commemoratio in the secret for Dom. IX p. Pent.: quoties hujus hostiae commemoratio celebratur, opus nostrae redemptionis exercetur, 120. The interpretation of hostiae commemoratio as a genitivus inversus makes the sense of the prayer at once clear and the sacramental content of hostia evident ${ }^{2}$.

Once hostia is used for the sacrificies of the OT which found their perfection in that of Calvary. This is in the secret for Dom. VII p. Pent.: Deus qui legalium differentiam hostiarum unius sacrificii perfectione sanxisti, 383. The expression: hostiae spiritales oblatione suscepta, 907, is an evident reference to 1 Pet. 2, 53. For a discussion of hostiam laudis see p. $193 \mathrm{f}$.

Hostia has a definite ritual sacramental character in the ORATIONs, but it shows no sign of the much later semantic development whereby its meaning was limited to refer specifically to the bread offered for the sacrifice or to the species of the consecrated bread, from which development derives the English word host" from French "hostie".

1 But see discussion of preces, p. $141 \mathrm{f}$.

2 Diezinger, op. cit., sees the reference to the historical death of Christ in hostia, and not in opus redemptionis nosirae. This is in opposition to the theory of Odo Casel, JLW 11, 1931, p. 35 ff. The reasoning of Diezinger is, on the whole, we think, accurate; but he overlooks the possibility of the genitivus inversus (Cf. SCHRJNen-MoHRMANN, op. cit., I, p. 86 f.) By interpreting hostiae as an objective genitive, he loses the value of hujus which refers to the sacred ritual action here and now in progress. The translation by Mohrmann in the Jesus, Mary, and Joseph Daily Missal, New York, 1962, p. 465, seems to take into consideration all the philological problems: "for as often as this sacrifice of commemoration is offered, the work of our redemption is performed". See also p. 45 , note 4 and p. 53 .

s Sacerdotium sanctum offerre spirituales hostias.

- Cf. Rheinfelder, Kullsprache, p. 258. 
Sacrificium, besides being the very general word for sacrifice in pagan Latin, had also a very broad meaning in Christian Latin. St. Augustine's well-known definition in $D e$ civ. Dei shows just how all-inclusive it was: Proinde verum sacrificium est omne opus quo agitur, ut sancta societate inhaereamus Deo, relatum scilicet ad illum finem boni, quo veraciter beati esse possimus ${ }^{1}$. St. Cyprian already applies it specifically to the Eucharist: celebrare sacrificia divina ${ }^{2}$.

This is its most general meaning in the ORATIONs; viz., the Eucharist as such: Subveniat nobis... sacrificii praesentis oblatio, 1073; ut hujus sacrificii munus oblatum, 130. Again, it refers to the Eucharist simply as the cultic act which marks the opening of the solemn fast of Lent: Sacrificium... observantiae quadragesimalis quod offerimus, praesta... ut tibi et mentes nostras reddat acceptas, et continentiae promptioris nobis tribuat facultatem, 1012; Sacrificium quadragesimalis initii, 1016.

Still sacrificium has a more nuanced character in the ORATIONS than at first sight is evident. We have been able to distinguish at least four different, though related meanings for this all-important word. The one sacrifice of the NT which gave meaning to the sacrifices of the Old Law is that of Christ on Calvary. The Eucharist as the renewal of this unique sacrifice is specifically referred to in the secret of Dom. VII $p$. Pent.: Deus, qui legalium differentiam hostiarum unius sacrificii perfectione sanxisti, 383. The Eucharist is also called the sacrificium singulare, 892. In the secret for Fer. V p. Dom. III Quadr., which in the Gel. Vetus was that of Ss. Cosmas and Damian ${ }^{3}$; sacrificium illud offerimus, de quo martyrium sumpsit omne principium, 642, the Eucharist is regarded as the source of martyrdom in as much as it is the sacrifice of Christ.

In the second place it represents specifically the gifts brought by the faithful to the altar in the offertory rite. The secret for Dom. VII p. Pent. contains a clear example of this meaning of sacrificium: accipe sacrificium a devotis tibi famulis... ut, quod singuli obtulerunt ad majestatis tuae honorem, cunctis proficiat ad salutem, 383. That of Fer. VI Quat. Temp. Pent. also gives a graphic picture of the gifts brought by the faithful: Sacrificia... tuis oblata conspectibus, 1004. See also 831, 1015, 1121, 1134. Even more effective is the secret of Fer. III Maj. Heb.: Sacrificia... propensius ista nos salvent, quae medicinalibus sunt instituta jejuniis, 1003. This prayer deserves an extra comment. It is well known that very early the

1 De civ. Dei 10, 6.

2 Epist. 76, 3.

This secret is now used on Thurs. after III Sun. of Lent because the stational service is in the church of Ss. Cosmas and Damian. 
fasting practice of the Christians was connected with charity. What was saved through fasting was given to the poor 1 . In addition, the works of Lent - prayer, fasting, and alms - were frequently referred to by "Opfertermini"2. Hence the word sacrificium indicates both the actual material gifts brought to the altar and the penitential act of fasting as well. The relative clause makes this clear, for the antecedent of quae is sacrificia, and instituta must have here the sense of "prepared" 3 Fasting, then, prepares the material gifts for the Eucharist proper and for the poor, and it effects the sacrificial disposition as well. The sacramental connotation of sacrificium (which will be discussed below) is also included here, as the word salvent indicates. Thus, we have in this prayer not only a succinct expression of the intimate relationship between charity, the spirit of sacrifice, the Eucharist, and salvation; but we have also an excellent specimen of how in the ORATIONs an enrichment of the thought-content of a word is brought about by the compactness of the style. The connection between charity and the gifts brought to the altar seems to be implied also in the secret, ad postulandam caritatem: ut caritatis donum... per haec, quae offerimus sacrificia, facias veraciter apprehendi, 397.

Not every time that offerre is used with the noun sacrificium does the latter refer to the material gifts. Or perhaps, better stated, there are five instances which emphasize, by using verse 8 of Ps. 1154, the inner spiritual character of the sacrifice which is symbolized by the material offerings. The verb sacrificare, which was a very general word for "to offer sacrifice" both in pagan and in Christian Latin, finds its way into the orations only once and that is by way of this reference to Ps. 115, 8: ut sacrificare tibi hostiam laudis... possimus, 472.

Because the Eucharist perpetuates the unique redemptive sacrifice of Calvary, the word sacrificium, when it stands for the Eucharist as such, has a sacramental connotation. It is represented as the source of grace, as producing an inner supernatural effect: Munda nos... sacrificii praesentis

1 Cf. p. 182, note 3.

2 Unde et ipsa misericordia qua homini subvenitur, si propter Deum non sit, non sit sacrificium, Aug., De civ. Dei 10, 6; eleemosynarum sacrificio, Leo, Sermo 9, 4; ut sacrificium misericordiae non cum tristitia offeratur, Leo, Sermo 88, 5; cf. L. EizenhöFer, Das Opfer der Gläubigen in den Sermonen Leos des Grossen, in Fr. X. Arvolo-B. Fischer, Die Messe in der Glaubensverkündigung, Freiburg 1950, p. 79 ff.; HERz, op. cit., p. 271 f.

- Cf. instituere dapes, Verg., Aen. 7, 109; convivium instituere, Just. 12, 13, 5; eos... voluptates... institutis et volunteriis molestiis homines adquirunt, Aug., Conf. 8, 3, 7; C. L. HRDLICKA, A Study of the Late Latin Vocabulary and of the Prepositions and Demonstrative Pronouns in the Confessions of Saint Augustine, Washington, D.C. 1931, p. 77.

- Cf. discussion of Ps. 115, 8, p. $193 \mathrm{f}$. 
effectu, 686; Deus, qui nos per hujus sacrificii veneranda commercia, unius summae divinitatis participes efficisti, 409. Various supernatural effects mentioned are the same as those found in connection with sacramentum, mysterium, munera, hostia, oblatio: nos salvent, 1003; vivificet nos... et muniat, 734 ; nos purificet, 1005; sacrificium celebrandum ${ }^{1}$... corpora mentesque sanctificet, 581 ; per hoc sacrificium emundemur, 484 . It is used frequently also as an ablative of means: His sacrificiis placatus, 605, 1008, 1011 ; his sacrificiis... mundemur, 1099. Especially in prayers for the faithful departed is sacrificiis viewed as a means of a release from sins: His sacrificiis... anima... a peccatis omnibus exuatur, 606. See also 608, 845, 892.

Of the 32 times that this noun occurs in the orations, only six are in postcommunions. Two of these latter have also the verb obtulimus and hence refer definitely to the sacrifice as a whole; two are prayers for the faithful departed, 608, 645. One of the remaining two, namely, that of Fer. VI p. Dom. I Pass. begins with the words: Sumpti sacrificii... perpetua nos tuitio non derelinquat, 1086. The other is that of the feast of St. Augustine: Ut nobis... tua sacrificia dent salutem, 1172. In these there may be a further limitation of meaning, and sacrificia may refer concretely to the sacred species. Zeno of Verona, in speaking of the sacred species reserved in the homes of the Christians says: arreptoque forsitan ipso sacrificio tuo ${ }^{2}$. The Council of Arles speaks of negligentiam erga sacrificium facere $e^{3}$. In referring to the reservation of the sacred species on Holy Thursday for reception on Good Friday, the Gel. Vetus has this note: Hoc autem expleti venies ante altare, ponis in ore calicis de ipsa hostia; non dicis Pax Domini nec faciunt pacem; sed communicant, et reservant de ipso sacrificio in crastinum unde communicent". Thus we may say that sacrificium with the meaning "sacred species" was indeed living at the time of the origin of the oldest sacramentaries, but it was not usual in the euchology itself. Here we have

1 Ad, which appears before sacrificium in the present text of the MR seems to have been added only in the MS, Vat. Ottob. Lat. 313. It does not appear in the MSS of the Gregorianum, nor in the so-called Gelasiania saeculi VIIIi (See BruYLANTs, Les oraisons, II, p. 159, apparatus criticus). The reading without ad may be considered the lectio difficilior, for the use of the gerundive with ad to express purpose seems the most obvious interpretation for the phrase: ad sacrificium celebrandum. But see the discussion of the gerund and gerundive below, p. $145 \mathrm{f}$. Furthermore, to say "may the sacrifice which is being celebrated sanctify the bodies and minds" is far more in keeping with the general tenor of secrets than to say "may it (hostia) sanctify bodies and minds for the celebration of the sacrifice". The secrets consider the offering of the gifts as part of the sacrifice, not as a preparation for it.

2 Tract. 1, 5, 8.

3 J. D. MAnsi, Sacrorum conciliorum nova et amplissima collectio (Reimpression and continuation, I-LIII, Paris-Amhem-Leipzig 1901-1927), VIII, col. 365.

- Mohlberg, p. 63. 
another clear example of how the ritual character of the Eucharist is emphasized in the prayers.

We may, then, say with Brou that "sacrificium est le mot propre des secrètes anciennes" 1 . It designates the Eucharist as a whole;it refers to the gifts brought by the faithful. Twice at least, these gifts are related to the broader interpretation of the word sacrificium which includes the works of Christian charity and fasting. The more limited meaning, "sacred species" is avoided except for 2 somewhat doubtful instances, 1086, 1172.

MUNUS; See LEGAL TERMS, p. $163 \mathrm{f}$.

oblatio, OFFERRE, OBLATA

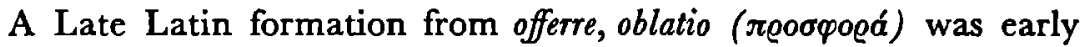
used in connection with the Eucharistic celebration ${ }^{2}$. The Latin translation of the Letter of St. Clement of Rome to the Corinthians 40, 4 renders

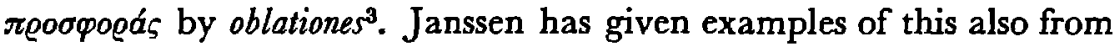
Tertullian and Cyprian 4 . As a regular term for the Eucharist it remained in use at least until the sixth century.

Within the prayers this noun sometimes takes on a very concrete sense. In the first place, it occurs only in secrets ${ }^{8}$. This fact leads to the impression that oblatio refers specifically to the offerings brought by the faithful, especially since in the Gregorian type of sacramentaries the secret was named oratio super oblata. This impression is strengthened by the use of oblatio in the plural and with such verbs as assume, suscipe, respice ${ }^{7}$ for God's action. Thus we have on Dom. V and Dom. VI p. Pent.: has oblationes... benignus assume, 901, 903. Similarly, on Dom. IV p. Pent. we pray: Oblationibus nostris... placare susceptis, 729; and on Dom. XXIV: populi tui oblationibus, precibusque susceptis, 908.

The phrase: Suscipe... preces cum oblationibus hostiarum, 1106, 1130, 1131 , is a typical pleonastic group ${ }^{8}$ which can be construed as a genitivus

1 Les oraisons dominicales, p. 48.

2 Cf. Janssen, op. cit., p. 105; HrDLICKa, op. cit., p. 112.

a C. Th. Schäper, Clementis Romani epistula ad Corinthios quae vocatur prima graece et latine, Bonn 1941, p. 46.

op. cit., p. $105 \mathrm{ff}$.

5 Cf. Bastlaensen, op. cit., p. 88 ff.; J. A. Jungmann, Missarum sollemnia. Eine genetische Erklärung der römischen Messes, (I-II, Wien 1962), I, p. 226 f.; MohrmanN, VG 12, 1958, p. $75 \mathrm{ff}$.

- In all the sources prior to the first printed edition of the MR (cf. BRUYLANTs, Les oraisons, II, p. 158), the word oratio stands in the place of oblatio in the postcommunion, Pro rege: Haec... oblatio salutaris... tueatur, 578. Hence this prayer does not fall within the work considered here.

7 Cf. p. 87 f., 88, 89.

C. Cf. also preces, p. $140 \mathrm{f}$. 
inhaerentiae meaning simply "gifts"; or oblationibus could mean the "act of offering", used in the plural by analogy with preces, and in this case hostiarum would be an objective genitive. Both interpretations maintain the basic content of the prayer. It is interesting to note that oblatio is used with other nouns in the genitive case also: Purificet nos... muneris praesentis oblatio, 925; Subveniat nobis... sacrificii praesentis oblatio, 1073. This emphasizes once again the verbal idea in oblatio, and one tends simply to translate, "the offering of this gift" or "of this sacrifice". But if one bears in mind the ritual content of munus and of sacrificium, then one sees that muneris and sacrificii may quite well be genitivi inhaerentiae. Furthermore, there is: munera nostrae oblationis... suscipe placatus, 699, where oblatio itself is in the genitive. Again, there is a certain ambiguity. If we translate it, "the gifts which we offer", oblationis may be either subjective genitive or genitivus inhaerentiae. The same explanation would apply to: Sanctifica... hujus oblationis hostiam, 1039; and to: Grata tibi sit... nostrae servitutis oblatio, 572 . Two conclusions follow from this discussion: (1) the genitive is used probably with a view to style (viz., to add by means of the pleonasm a certain solemn abundance to the prayers), rather than to mark a minute distinction between the various words for sacrifice; and, (2) the verbal element in oblatio was very strongly felt.

This latter statement is further substantiated by the fact that a verb meaning "to offer" (offerre, deferre, or immolare) is rarely used with oblatio in the three oldest sacramentaries. The three instances which are also in the MR are: has oblationes, quas... deferimus, 881 ; quas... offerimus, 902; and oblatio, quam immolando... tribuisti relaxari delicta, 54.

The word oblatio means the ritual action, and as such it has a markedly sacramental character. It is called sacra oblatio, 81 ; oblatio salutaris, 158; mystica oblatio, 717. It is also visualized as producing supernatural effects: Benedictionem conferat, 81 ; nos a reatibus expediat et ab omnibus tueatur adversis, 158; mundet et renovet, gubernet et protegat, 589 ; ab omnibus nos purget offensis, 592; cordis nostri maculas emundet, 594 ; nobis... prosit, 717 ; nos... purificet, 727, 925; Subveniat nobis, 1073; proficiat prosperitatem et pacem, 1144. Not only does the noun when it is used in the singular have a sacramental content, but also, though not so frequently, when it is used in the plural: has oblationes... benignus assume, ut... nobis proficiant ad salutem, 881, 901, 902.

One of the earliest terms employed for the "celebration" of the Eucharist, offerre was already a technical term in the time of Tertullian. This is evident from the fact that he uses it absolutely in De virg. veland. 9, 2: Non permittitur mulieri in ecclesia logui, sed nec docere, nec tinguere nec offerre. Within the ORATIONs the word sometimes means the actual 
bringing of material gifts by the faithful, as the secrets for Dom. V and Dom. VII p. Pent., for example, clearly illustrate: quod singuli obtulerunt ad honorem nominis tui, cunctis proficiat ad salutem, 383, 901. Here the use of the perfect tense in a secret prayer makes obtulerunt point to the action which the people have just performed.

On the whole, however, this verb is by no means so restricted in meaning. It is used with munus: Haec munera... quae oculis tuae majestatis offerimus, salutaria nobis esse concede, 586 and 26, 530, 554, 699, 700, 703, $707,713,739,1111,1160$; with sacrificium : per haec, quae offerimus sacrificia, 397 and 484, 642, 831, 1012, 1134; with hostia: Hostias... quas tibi offerimus, propitius respice, 615 and 620,623,624,627, 1119, 1120; with oblatio 881, 902. All of these nouns have a markedly ritual content and this fact manifests that offerre expresses the essential content of the Eucharist. What other than the entire ritual action could the word denote in the prayers quoted above? Even when there is question of offerre sacrificium or hostiam laudis ${ }^{1}$, reference is made to the Eucharist as such.

Only twice is there, as it were, a reflection on the relation between the Christian's personal moral attitude and the Eucharist as an act of worship and source of grace, so that offerre receives a more subjective character. These are the secret for Sabb. p. Cin.: Suscipe... sacrificium, cujus te voluisti dignanter immolatione placari: praesta... ut, hujus operatione mundati, beneplacitum tibi nostrae mentis offeramus affectum, 1121; and that of Sabb. Quat. Temp. Pent.: Ut accepta tibi sint... nostra jejunia : praesta nobis... hujus munere sacramenti purificatum tibi pectus offerre, 1169.

The perfect passive participle of this verb is a favorite expression in the orations. Of the 25 times that it occurs, it is used 21 times with the noun munus. Fixed expressions play an important role here: Oblatis... placare muneribus, 731, 730, 732, 733; Suscipe... munera... oblata, 1108, 1125 ; Suscipe munus oblatum, 1128, 1132. But to be noted is the fact that oblata never occurs in a nominal sense in the orations.

It was undoubtedly under influence of the frequency of the phrase munera oblata that the perfect participle underwent the semantic development whereby it ended in becoming a technical term for "the gifts of the faithful". In the Gregorian type of sacramentaries the "secret"' is entitled, oratio super oblata. Though this technical nominal form oblata was used at the time when these prayers were composed,

1 Cf. p. 193.

${ }^{2}$ This word is derived from the word secreta, which is found in the Gelasian type of sacramentaries; for a discussion of the origin of this term and related bibliography, see Jungmann, Missarum Sollemnia ${ }^{5}$, II, p. $113 \mathrm{fF}$. 
still the verbal form maintained itself within the prayers proper. This is another indication of the emphasis placed by the composers of the ORATIONs on the ritual action rather than on things.

\section{DEFERRE}

This verb has sometimes a cultic sense in pagan Latin. The Thesaurus cites examples from Cic., Val., Max., Quint., Apul., where it means dedicare or sacrificare ${ }^{1}$. Christian authors now and then employ it in the same manner: dies festus quo sacrificium sollemne deferebatur ${ }^{2} ;$ hoc... obsequium domino deferamus ${ }^{3}$. It has not become a technical term for "to offer sacrifice" to the degree that offerre has". This is evidenced also in the ORATIONs where it occurs three times in collects in connection with some word meaning prayer. The solemn prayer for the Jews on Good Friday has: exaudi preces nostras, quas... deferimus, 778; that for the Mass $\mathcal{F} u s t u s$ has: Adesto... supplicationibus nostris, quas... deferimus, 31 ; and that of 11 April: Exaudi... preces nostras, quas... deferimus, 540.

For the rest it occurs in secrets one-half so frequently as offerre, and with the usual words for sacrifice or offerings; with hostias, 53, 618, 621, 625,626 ; with munera : $74,119,514,688,701,919,980,984,1109,1110$, 1127; with oblationes: 881 ; sacrificia: 1137 ; devotio: 8 . The sacrificial character of jejunium ${ }^{6}$ is well known, and hence it is not surprising that deferre is used with it in Or. 5a for Sab. Quat. Temp. Sept.: Ut nobis... tribuis solemne tibi deferre jejunium, 1171. Although deferre has essentially the same sense as offerre, it is less technical, less concrete than the latter. That it is a more vague and general term can also be noted from the fact that it has no derived noun, such as, for example, oblatio and oblata from offerre.

DICARE; See PAGAN ROMAN RELIGIOUS TERMS, p. $138 \mathrm{f}$.

\section{DONUM}

Although the lofty hieratic pleonasm used in the Te igitur to designate the gifts upon the altar - haec dona, haec munera, haec sancta sacrificia illibata - might give the impression that donum is in liturgical Latin on a par with munus and sacrificium ${ }^{6}$, a closer examination of the usage of

, Cf. TLL V, p. $316 \mathrm{f}$.

2 Heges, 1, 5.

3 Lact., Epit. 62, 3.

Cf. p. 113, note 4 for the frequency of deferre on feasts of saints.

5 Cf. p. 78, note 2.

- Jungmann is right when he says that these three are synonyms and that we must not seek to find differences of meaning behind them. Cf. Missarum Sollemnia $a^{5}$ II, p. $189 \mathrm{f}$. But his statement: "Alle drei Benennungen kommen zur Bezeichnung derselben 
this word in the ORATIONs shows that this impression needs modification, at least. It is true that dona does refer a few times ( 5 of the 37 instances of its occurrence) specifically to the gifts of the faithful. In the secret of Epiphany we pray: Ecclesiae tuae... dona propitius intuere, 515. That the word refers specifically to the gifts which were used for the sacrifice, rather than to those destined for the poor can be determined from the context of the following secrets: that of 25 Jan.: plebis tuae dona sanctifica, 57; of Fer. II infra. Oct. Pent.: haec dona sanctifica, 907; In die Ded. Altaris: Descendat Spiritus tuus Sanctus super hoc altare: qui, et populi tui dona sanctificet, 198; and that of Fer. VI Quad. Temp. Quadr.: et tua propitius dona sanctifica, 1125.

Note that in the last-quoted prayer tua dona reminds one of $\tau \dot{a} \sigma \dot{a} \varepsilon \kappa \tau \tau \bar{\omega} \nu$

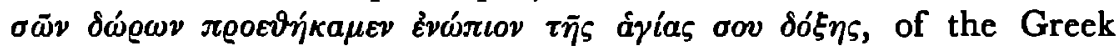
liturgy of Egypt ${ }^{1}$ and of the de tuis donis ac datis of the Roman Canon Missae. This may give us a hint as to the thought content as well as to the sensitivity regarding donum in Liturgical Latin and in Christian Latin in general. The word had a sacral character ${ }^{2}$ in pagan Latin, it is true, but it had a very general sense of "gift" in the ordinary spoken language as well.

Everything which man has is a gift of God; and hence what man "offers" to God is His own gift. It is interesting to note, too, that where the Vetus Latina has dona in Lev. 1.2: se obtulerit dona domino, the Vulgate has hostiam; and where Codex $\mathrm{C}$ has dona in Luke 21, 4: de eo... miserunt in dona dei, the Vulgate has munera. Man can bring God an "offering", but not really a gift.

The further use of donum in the orations bears this out. Donum was one of the native Latin words which replaced the Greek $\chi$ á $\varrho \iota s$ as a term for "grace"3. The genitivus inhaerentiae in: ut, qui tua per eum beneficia poscimus, dono tuae gratiae consequamur, 401 ; nobis gratiae tuae dona conciliet, 1031 , makes it clear that donum in these cases is "grace". Various aspects of this supernatural gift of God are referred to by this word. Now it means "grace" in a very general sort of way, as in the postcommunion for 23 Nov.: ut intercedentibus Sanctis tuis, et tua in nobis dona multiplices, 1100, or the collect for Sabb.p. Dom. I Pass.: ut sacris actionibus erudita quanto majestati tuae fit gratior, tanto donis potioribus augeatur, 898. Again it Sache, nämlich der materiellen Gaben, auch in den Formeln der Secreta vor", needs modification, as we shall see from what follows.

1 Cf. A. Baumstark, Das Problem des römischen Messkanons, EL 53, 1939, p. 220 ff., ref. to p. 229; Chr. Mohrmann, Quelques observations sur l'évolution stylistique du Canon de la Messe romaine, VC 4, 1950, p. 1 ff., esp. p. 17 f.

2 Cf. TLL V, p. $2017 \mathrm{ff}$.

3 Mohrmann, Eludes, I', p. 117. 
refers to the supernatural aid needed to serve God, as in the secret of 18 Oct.: Donis caelestibus da nobis... libera tibi mente servire, 514 ; and in the secret of Fer. II infra Oct. Pasch.: populum tuum... caelesti dono prosequere, 448. And finally it seems to have an eschatological content in the collect for 27 Dec.: ut beati Joannis... illuminata doctrinis, ad dona perveniat sempiterna, 520. Various virtues, too, are seen as gifts of God. Thus, there is mention of caritatis donum (a),312, 397; of patientiae donum, 699; and of continentiae salutaris... dona, 5361. In the postcommunion for 21 Dec. it refers to supernatural gifts in general: tua circa nos propitiatus dona custodi, $35^{2}$; while in almost the same phraseology it is restricted to "the special graces of Orders" in the secret for the consecration of a bishop: ut propitius in eo tua dona custodias, 111.

Finally, donum represents participation in the Eucharist. It is found with the usual words for such participation: capere: Caelestia dona capientibus, 95; sumere: Sumentes dona caelestia, 1076; sumpsimus... sacri dona mysterii, 1083; percipere: dum dona tua... percipimus, 1179; Votiva... dona percepimus, 1182; satiare: Quos caelesti dono satiasti, 1158-3. See also 677, $585,812,1044$. In secrets there is generally a broader sense discernible. The word refers indeed to the fruit of the Eucharist, but it has a more general connotation. In other words, the Eucharist is not so much regarded as being itself a gift, but rather as being productive, as "leading to" caelestia dona. Dona, in these instances is the increase of supernatural life (grace) which is the direct result of the Eucharistic action. In the secret of Dom. I Pass. we have: Haec munera... et tuae nobis misericordiae dona concilient, 585 ; in that of Fer. III p. Dom. III Quadr.: qui (effectus redemptionis) nos et ab humanis retrahat semper excessibus, et ad salutaria dona perducat, 812; and that of Fer. III p. Dom. II Quadr.: quae (mysteriis) nos et a terrenis purget vitiis, et ad caelestia dona perducat, 1044.

To sum up, we may say that the usage of donum in the orations is based more on the specific Christian meaning of the word as "grace of God" than on the pagan sacral sense of this word. It means "grace", virtues as gifts of God, the effect of the Eucharist, and the Eucharist itself as something to be "shared".

IMMOLARE; SEe PAGAN ROMAN RELIGIOUS TERMS; p. 139.

SAGRARE, CONSEGRARE; STe PAGAN ROMAN RELIGIOUS TERMS, p. $144 \mathrm{ff}$.

1 Continentiae has here a broader meaning than the English "continency". See p. 182. note 4.

${ }^{2}$ Its use in the present MR is in a postcommunion and hence dona could refer specifically to the sacramental gifts of the Eucharist; but since some of the old sacramentaries, among them also the Gregorianum, employed it as a Vesper prayer (Cf. BRUYLANTs, Les oraisons, II, p. 19), we may conclude to a more general interpretation of the noun. 


\section{Terms which express the action of God in regard to the gifts}

ACCIPERE, to accept, to take unto one's self, to receive.

A third century grammarian defined this verb as follows: accipere est datum sumere, and Ps. Fronto: sumimus quae posita sunt, accipimus quae porriguntur ${ }^{1}$. In a religious sense, however, it is regarded from the point of view of the "receiver" and has reference to the favorable attitude of the Higher Powers to the prayers and (or) sacrifices of their votaries. Thus Ovid has: Accipe sub certa conditione preces ${ }^{2}$, and Livy: preces suas acceptas ab diis immortalibus ${ }^{3}$. Bonnet points out that from the end of the second century B.C. there are many examples where accipere is said of him who of his own free will takes something unto himself 4 .

It seems that in the ORATIONS we have an application of this last sense, when the verb is used in secrets: Accipe... munera dignanter oblata et... ad nostrae salutis auxilium provenire concede, 17; Accipe sacrificium a devotis tibi famulis, 383; ut easdem (hostias laudis)... et placatus accipias, et ad salutem nostram provenire concedas, 623; Accipe munus oblatum, et dignanter operare, 1128-2. Although the second clause is joined paratactically to the first, there seems to be a close relationship between God's acceptance of the gifts and their supernatural productivity in 17, 623, and 1128-2.

This verb is, though, not confined to secret prayers. It also has the special sense of "to receive with the hands or with the mouth"5. When it occurs in postcommunions, we may consider it as having this concrete meaning: ut, quod de sancto altare tuo accepimus... sanctificet animas nostras, 871; Sacramentis... muniamur acceptis, 999; ut his muneribus... et te placemus exhibitis, et nos vivicemur acceptis, 119 . The word receives something of a legal coloring by its connection with pignus ${ }^{6}$ : accepto pignore salutis aeternae, 551 ; cujus (effectum) per haec mysteria pignus accepimus, 940. Under the heading of de effectu capiendi, "to acquire, to participate in", this word is frequent in the NT, and in Christian authors as well ${ }^{7}$. It occurs three times with this connotation: Benedictionem tuam... populus fidelis accipiat,

1 Cf. TLL I, p. 304, line 51 ff.

Fart. 4, 320.

$42,30,8$.

4 Cf. Max Bonnet, Le latin de Grégoire de Tours, Paris 1890, p. 263.

s The practice in the early Church was to receive the consecrated bread in the hands, as, for example, St. Cyril of Jerusalem so graphically describes it, Catech. myst. 6, 21. It was in the 9th century that the sacred host was first received directly in the mouth. Cf. Jungmann, Missanum Sollemnia ${ }^{5}$, II, p. $468 \mathrm{ff}$.

- Cf. H. Heumann-E. Seckel, Handlexikon zu den Quellen des römischen Rechts ${ }^{\mathbf{1 0}}$, Graz 1958, p. 412. W. DürIG, Imago. Ein Beitrag zur Terminologie und Theologie der römischen Liturgie, München 1952, p. $62 \mathrm{ff}$.

7 Cf. Rönsch, Itala und Vulgata, p. 374; TLL I, p. 315. 
82; incrementa libertatis accipiat, 965b; remissionem... accipere, 752.

The adjective acceptus was a pagan cultic term: nihil ei (Iovi) acceptumst $^{1}$; Acceptam dis hostiam ${ }^{2}$. In combination with habere it was also a technical legal term as well: hostiam acceptam habeas et consumas ${ }^{3}$. On the other hand, acceptus is rather common in the Vetus Latina and the Vulgate, as also in Christian writers ${ }^{4}:$ hostiam acceptam, placentem deo ${ }^{5}$; cujus sacrificium... tum acceptum deo fuisse ${ }^{6}$. It seems that the Christian usage has been the source whence it entered into the orations. The "sacrificial" character of the word is evident from the fact that it occurs almost exclusively in secrets, and that it is attributed to such terms as: oblatio, $12,13,1167$; munera, 80, 697, 831, 981 ; sacrificium, 1015, 655; devotio, 8; jejunium, 11, 1169.

This adjective furnishes a clear example of the stereotyped character of the language of the ORATIONs? ${ }^{7}$. It occurs either with esse: accepta sit... nostra devotio, 8 ; sacrificium... sit tibi munus acceptum, 831 ; see also 11,12 , 13, 722, 981; or with reddere : Ipse tibi... sacrificium... reddat acceptum, 655 ; nos... tibi reddat acceptos, 1050; also 80, 74, etc. Only twice is the pattern changed, so that we have: Sacrificium... efficiatur acceptum, 1015, and oblationem... faciat acceptam, 1167. In the postcommunion for Fer. IV p. Dom. III Quadr.: Santificet nos... mensa caelestis: et a cunctis erroribus expiatos, supernis promissionibus reddat acceptos, 1048, it is not difficuit to see that the presence of reddere called for acceptus, where aptus or dignus would have fit the context better.

\section{ASSUMERE, to accept.}

This verb, which was not found before Rhetorica ad C. Herennium, and was rare in the poets and historians, was a favorite word among Christian writers, especially St. Hilary ${ }^{8}$. Its predominance in the colloquial Christian Latin may be a partial reason for its scarcity in the orations. Its meaning "to take up" is the one which occasioned its use in secrets for God's act of accepting the gifts offered. It occurs five times in this sense, four of which are in the fixed expression: has oblationes... benignus assume, 881, 901, 902, 903; and one in: Hostias placatus assume, 618.

1 Plaut., Rud. 2, 5.

2 Verg., Georg. 2, 101.

CIL I, 818. N.B. the expression accepta habeas in the Canon of the Mass; cf. BotTEMohrmann, op. cit., p. 74.

4 Cf. Rönsch, Itala und Vulgata, p. 109; TLL I, p. $320 \mathrm{ff}$.

- Phil. 4, 18.

- Aug., De civ. Dei 15, 18.

- Cf. Mohrmann, Études, II, p. 107.

- Cf. TLL II, p. 926. 
The word stands for "to undertake" in: ut castigatio carnis assumpta, ad nostrarum vegetationem transeat animarum, 181.

SUSCIPERE, to receive well, to take up.

Pagan Roman religious terminology applied suscipere not to the action of the gods, but to the act of the worshipper, for example: In religionibus suscipiendis caput est interpretare ${ }^{1}$; vota senatus suscipit ${ }^{2}$. In the ORATIONs, on the other hand, it is applied to the act of God. Its use, thus, stems not from the pagan sacral usage, but from its general proper sense "to accept". The word contains the idea of a free-will undertaking ${ }^{3}$ and thus means "to be pleased with". In this connotation it has become a technical liturgical term in offertory prayers ${ }^{4}$, standing in the place of emphasis, i.e., at the beginning of the secrets no less than 22 times. It occurs most frequently with munus (munera), 1107, 1108, etc., 14 times; then also with hostias, 892, etc., 5 times; oblationes, 729, 1133; and with sacrificium, 1121, 1134. In these, the accent seems to be on the concept of "accepting". But when the verb occurs in such phrases as: suscipe preces et hostias, 219, 318, suscipe preces et munera, 711, 1116; oblationibus precibusque susceptis, 908; merita suscipiens, 25 or the rhetorically expanded turn of speech: suscipe preces... cum oblationibus hostiarum, 1106, 1130, 1131 , the accent seems to shift more to "favorable regard". In addition to its technical use as an offertory prayer, suscipere occurs as a prayer of petition for the departed: suscipe preces nostras pro anima famuli, 1117; see also 217.

Several other meanings of the verb also occur, though rarely. It means "to undertake, to enter upon" in the phrases: ut jejuniorum veneranda solemnia... suscipiant, 833; tunc proderunt suscepta jejunia, 562; and here it comes close to the pagan cultic sense of the word. Twice it has the special sense of "to admit into one's company": quem Redemplorem laeti suscipimus, 410, per quam meruimus auctorem vitae suscipere, 440. This meaning is, further, applied figuratively to the act of "including in prayers": quos in oratione commendatos suscepimus, 209. Only once does it have that special technical Christian sense in relation to the Incarnation: Verbum tuum... carnem suscipere voluisti, 320.

INTENDERE, to look upon, to apply one's self to.

From the special tropical sense of intendere animam or intendere with

1 Cic., Vatin. 41.

Ovid., Fast. 6, 245.

3 Cf. J. P. KREBS-J. H. Schmalz, Antibarbarus der lateinischen Sprache? (I-II, Basel 1905-1907), II, p. 186.

- N.B. also the prayers Suscipe, Sancte Pater; Suscipe Sancta Trinitas; and Suscipiat Dominus. 
the dative, there developed the meaning for intendere with the accusative of "to look upon, to regard with favor"1. This verb is used only once in the orations with the dative: His... placatus intende muneribus, 603. For the rest, it is used with the accusative of hostias, $616,619,620 ;$ munera, 650 , $703 ;$ nos, 705; gregem, 576b; vota, 1180. This "regard" of God is visualized as having a supernatural effect upon the gifts in the secret for Dom. XII p. Pent.: Hostias... intende... ut nobis indulgentiam largiendo, tuo nomini dent honorem, 619. In addition to the use of this verb in reference to the regard of God for the gifts offered, it occurs twice in the adjectival form, intentus, meaning "being intent upon": ut jejuniis et orationibus... intenti, 837; bonis operibus... esse intentos, 1150.

RESPICERE, to look upon, to regard with favor ${ }^{2}$.

Of this sacral word Norden says that it "die Rücksichtnahme der Götter auf notleidende Menschen bezeichnet"3. Thus Terence has: di nos respiciunt ${ }^{4}$; and Cicero: nisi... deus respexerit rem publicam ${ }^{5}$. This verb occurs quite frequently. in the Vulgate also for the merciful care of God for men $^{8}$ : quia respexit humulitatem ancillae suae $e^{7}$, to quote but one example.

One of the concrete applications of this term was to the "favorable glance of the deity" upon gifts offered. Such favorable regard was the token of acceptance. This figure is one of the earliest and the most universal ${ }^{8}$. It was used by pagans, and it is found in Sacred Scripture as well. Thus in the Vulgate it is said of the sacrifice of Abel: Respexit Dominus ad Abel et ad munera ejus ${ }^{\circ}$. In the orations, too, it appears in this more restricted sense in reference to the gifts in secrets. That for Fer. IV p. Dom. II Quadr. has: Hostias quas tibi offerimus, propitius respice, 615; that of Dom. III p. Pent.: Respice munera... supplicantis Ecclesiae, 979; that of Dom. XI p. Pent.: Respice... nostram servitutem, 981 ; that for the feast of the martyrs 19 Jan.: Preces... tuorum respice, oblationesque fidelium, 882; see also $600,978,980,984$. The final clause in the secrets sometimes brings out the fact that this "glance of God" was regarded as having a sanctifying effect; for example, the secret for Fer. VI p. Dom. III Quadr.: Respice... propitius ad munera, quae sacramus: ut tibi grata sint et nobis semper

1 Cf. RöNsch, Itala und Vulgata, p. 371 f.; BonNET, op. cit., p. 256.

2 Cr. Forcellini-de VrT, V, p. 205; Antibarbarus, II, p. 464.

3 Eduard Norden, Aus altrömischen Priesterbücherm, Lund 1939, p. 47.

- Phorm. 8, 17.

- Ad Att. 7, 1, 2.

- Cf. Dutripon, op. cit., p. 467.

7 Lk. 1, 48.

- Cf. H. Schemt, Die Taufwasserweihegebete, Münster in Westf. 1935, p. 29.

- Genesis 4, 4-5. 
salutaria existant, 986. Respicere is also one of the verbs found in epiclesis formulae. Thus, for instance, we find: ut hanc oblationem nostram respicere et benedicere digneris; and ut... oblatas tibi victimas sereno vultu respicias, in the Liber Mozarabicus Sacramentorum ${ }^{1}$. Scheidt remarked that ė $\varepsilon \pi i \beta \lambda \eta \psi o \nu$ and respice occur also in the earliest epicleses of the blessing of the font ${ }^{2}$. This similarity between the language of offertory prayers and that of epiclesis formulae is seen also with the word sanctzficare, which appears repeatedly in Mozarabic and Gallican epiclesis texts, for example: sanctifica haec munera impuris manibus tibi delibata; or sanctificans haec, quae tibi offerimus ${ }^{3}$. Then there are three secrets containing descendere, a word which might be called a technical epiclesis term. The secret for the dedication of an altar contains the words of a so-called pneumaepiclesis verbatim: Descendat... Spiritus tuus Sanctus super hoc altare, 198; while that of 8 Nov.: Benedictio tua... larga descendat, 80; and that for the second feast of St. Agnes: Super has... hostias benedictio copiosa descendat, 1095, call down the blessing of God upon the gifts. This similarity between offertory prayers and epicleses, Brinktrine has adequately recognized, and from it he has concluded to an essential identity of the two ${ }^{4}$. Lietzmann, on the other hand, maintains that there is merely a later reciprocal literary influencing, since the epiclesis is of earlier origin than are the offertory prayers ${ }^{5}$. However, this similarity of terminology may also point to the fact that, at the time of the origin of these prayers, the various "moments" of the sacred action were not so sharply delineated, as we, today, are wont to consider them.

In addition to the special sense of respicere in respect to the gifts offered, it is employed in the broader signification of "to regard favorably in order to help". Here it occurs only in the imperative ${ }^{6}$ and is found in such phrases as: famulum tuum... respice, 239, or respice super famulos, 749, 434. It is further used with populus, 395, 826, 827; familia, 935, 976; infirmitas, 649, 764, tribulatio, 1142. It is employed with preces, $319,414,753,757 ;$ vota, 950 ; and devotio, 803 , in order to implore a favorable answer to petitions.

SANCTIFICARE; see Latin new-forms, p. $15 \mathrm{f}$.

${ }^{1}$ M. FÉRotrn, Le Liber Mozarabicus Sacramentorum et les manuscrits mozarabes, Paris 1912,809 and 980.

2 Op. cit., p. $85 \mathrm{ff}$.

- Liber Mozarabicus, 79 and 161 ; for other examples see Hans Lietzmann, Messe und Herrenmahl. Eine Studie zur Geschichte der Liturgies, Berlin 1955, p. $108 \mathrm{ff}$.

- J. BRINKTRINe, Zur Entstehung der morgenländischen Epiklese, Zeitschrift für kath. Theol. 42, 1918, p. 502 ff.; $517 \mathrm{ff}$.

8 Messe und Herrenmahl, p. $116 \mathrm{f}$.

- For the stylized use of propitius with respice, see p. 143. 
Under this head will be included words which refer to the performance of the ritual action in a somewhat more general sense. It is obvious that there will be some overlapping; for the Eucharist is the central cultic act of Christendom and there is no sharp line of demarcation between the terminology used exclusively for the Eucharist and that used for the performance of a ritual action as such.

\section{Words designating the ritual action as such}

AGERE, ACTTO, to perform a ritual or moral action; ritual or moral act.

It has become a commonplace to say that agere, actio are technical terms designating either the Eucharist as such, or in a broader application, the celebration of the liturgy in general'. After Bastiaensen's study ${ }^{2}$ of the origin and use of agere, actio as technical liturgical terms, it is not necessary for us to enter into that phase of the study here. We shall endeavor to determine what is the meaning of these terms in the ORATIONS.

The first thing that impresses one is the fact that these terms are relatively infrequent-agere occurs 8 times, and actio, 14 times. On the whole, they follow the same pattern. In the first place, both occur in the cultic sense. The postcommunion for the Martyrs, 19 Jan. has: ut, quae temporali celebramus actione, perpetua salvatione capiamus, 1056; that of Dom. VIII p. Pent.: Sit nobis... reparatio mentis et corporis caeleste mysterium: ut, oujus exsequimur actionem ${ }^{3}$, sentiamus effectum, 1065; the secret, Ad postulandum patientiam: Munera... suscipe placatus: quae... majestati tuae devota offerimus actione, 699. In all these, actio means "the ritual action which produces a supernatural effect". That actio as "the ritual action" is of a piece with the inner supernatural effect-distinguishable, but by no means separable from the latter-is evidenced unmistakably in 1065 above; for the antecedent of rujus is mysterium, which belongs

1 Cf. Odo Cased, Actio in liturgischer Verwendung, JLW 1, 1921, p. 32 ff.; Jungmann, Missarum Sollemnia", I, p. 229: "Die Messe feiern heisst bei Ambrosius ebenso agere wie offerre"; F. J. DöLGER, Kaiser Theodosius der Grosse und Bischof Ambrosius von Mailand in einer Auseinandersetzung zwischen Predigt und Messliturgie, Antike und Christentum 1, 1929, p. 54 ff.; Sol Salutis. Gebet und Gesang im christlichen Altertum, Münster in Westf. 1926, p. 295 f.; Bastlaensen, $o p$. cit., p. $40 \mathrm{ff}$.

2 op. cit., p. 40.

s All the sources of this prayer before the Missal of S. Pius V, 1570, have actionem here instead of cultum as it stands in the present MR. We consider cultum less good. It may have been patterned on No. 963, or it may be an expression of the classical spirit of the Renaissance. 
to both members of the parallelism ${ }^{1}$. This close relationship, which gives actio, agere a deeper content than that of "an external action", is also clear in the postcommunion for the Martyrs, 25 Oct.: quae temporaliter agimus, spiritualiter consequamur ${ }^{2}, 718$; and the secret for Dom. II $p$. Pasch.: Benedictionem... conferat... oblatio: ut, quod agit mysterio, virtute perficiat, 81 . Note that in this latter the sacred act oblatio is the subject of agit and of perficiat as well. We may say that both ideas; viz., the external action and the inner efficacy, are included in the one word actionibus in the phrase: ut sacris actionibus erudita, 898, of the collect of Sabb. p. Dom. I Pass. Agere, further, occurs twice in the sense of "to celebrate a liturgical feast": in the collect for Fer. IV infra Oct. Pasch.: ut per temporalia festa quae agimus, pervenire ad gaudia aeterna mereamur, 411 ; and that of Sabb. in Albis: qui festa paschalia venerando egimus, per haec contingere ad gaudia aeterna mereamur, 135. In both these, the liturgical celebration of a feast is also visualized as productive of supernatural effects. Hence the boundary between agere, "to perform a ritual action productive of supernatural effects", and agere, "to celebrate a liturgical feast", is anything but sharp ${ }^{3}$.

The well-known phrase gratias agere does not occur in the ORATIONs"; gratiarum actio occurs but three times. Once it is employed in a postcommunion, namely, that of Dom. p. Ascen.: Repleti... muneribus sacris: da...ut in gratiarum semper actione maneamus, 974, and twice in collects, namely, that of Missa pro temp. belli: ut, inimicorum suorum feritate depressa, incessabili te gratiarum actione laudemus, 317 ; and that of Missa pro infirmis: ut reddita sibi sanitate, gratianum tibi in Ecclesia tua referant actiones, 804. Gratias agere became, probably under the influence of the preceding dialogue ${ }^{5}$, the technical term for the introduction to the Vere Dignumpassages (which are equivalent, on the whole, to what we call, in the Roman usage, the preface) in the Latin Liturgy, where its meaning is much richer than the word for gratitude in the modern languages ${ }^{6}$. It had, thus, a fixed place and meaning of its own, to such an extent that

1 The second member of this prayer is brachyological : cujus = ejus-cujus.

2 This was an even more symmetrically balanced phrase in the Gel. Vetus: quae corporaliter agimus, spiritaliter consequamur, MOHLBERG, 1294.

- Cf. Bastlaensen, op. cit., p. 40

- It is interesting to note that when there is question of thanksgiving in the orations, the word referre, 804 (collect), 739 (secret), 576 (postcom.); or exhibere, 938 (postcom.), is used with gratias.

5 Cf. A. Baumstark-B. Botte, Comparative Liturgy, translated from the French (Liturgie Comparées, Paris 1953) by F. L. Cross, Westminster, Md. 1957, p. 88.

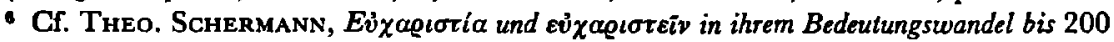
n. Chr., Philologus 69, 1910, p. 375 ff. 
gratiarum actio became one of the fixed designations for the Eucharist as such. This technical sense of gratias agere in the introductions to the Canon Missae undoubtedly accounts for its not occurring in the ORATTONs. In 317 and 804, gratiarum actio could mean "to celebrate the Eucharist" and, at the same time, "to render thanks"; to say nothing about the possibility that the simple connotation of "to give praise to God" may also be included. Such ambiguity is by no means foreign to the style of these solemn prayers; it adds a certain affluence which results from the association of ideas. In the postcommunion, 974, on the other hand, the meaning seems to be quite clearly, "to give thanks". The fact that the idea of thanksgiving occurs so seldom in the ancient postcommunions ${ }^{1}$ is evidence that these prayers were not on the whole regarded as "acts of thanksgiving after Holy Communion"; they were seen as part of the sacred ritual action itself.

Finally, agere, actio have a moral sense: Largire nobis... semper spiritum cogitandi quae recta sunt propitius et agendi, 660; ut, et quae agenda sunt videant, et ad implenda quae viderint, convalescant, 1181; ut videre possimus, quae agenda sunt; et quae recta sunt agere valeamus, 678 ; Actiones nostras... aspirando praeveni, 18; qui ex merito nostrae actionis affigimur, 134; quia ex nulla nostra actione confidimus, 315 ; quos actionis propriae culpa contristat, 646; quia pondus propriae actionis gravat, 649; et voluntate tibi et actione placeamus, 230 ; una sit fides mentium et pietas actionum, 326 . There are two instances to which I shall return presently.

A glance at the use of this word in the Veronense and the Gregorianum, and a comparison of the findings with those of the ORATIONs produce the following picture.

$\begin{array}{lrcl}\text { ACTIO } & \text { Veronense } & \text { Gregorianum } & \text { ORATIONS } \\ \text { cultic } & 6 \times & 4 \times & 4 \times(5 \times ?) \\ \text { moral } & 9 \times & 8 \times & 7 \times(8 \times ?) \\ \text { gratiarum actio } & 9 \times & 3 \times & 3 \times \\ \text { AGERE } & & & \\ \text { cultic } & 11 \times & 7 \times & 4 \times \\ \text { moral } & 9 \times & 3 \times(1 \times+i \text { ter }) & 4 \times \\ \text { gratias agere } & 5 \times & 5 \times & -\end{array}$

In the light of this schema, it seems clear that one need not per se seek a cultic content in agere, actio whenever the meaning is not at first glance evident. We come now to the two instances passed over above. In the first place, there is the secret for Fer. VI p. Dom. II Quadr.: Haec

1 Cf. p. 92, note 3. 
in nobis sacrificia, Deus, et actione permaneant, et operatione firmentur, 583, a classic specimen of compactness of phrase and ambiguity of content. Here we can rely very little on the context for help. But there are some general trends in the ORATIONs which are exemplified in this prayer and may be of assistance in determining the true meaning of actio here. The parallelism is surely intended to express something. If it is an antithetic parallelism, there are two interpretations possible: (a) either there is a juxtaposition of actio, "external rite", to operatio, "inner effect"; (b) or there is a distinction intended between actio in that fuller sacramental sense in which the outer action and the inner effect are seen as one reality, and operatio as "human acts". Both interpretations are possible. If, on the other hand, the parallelism is complementary, then both actio and operatio may be interpreted in a moral sense. Such a phenomenon, where the same petition is expressed in different words in a given prayer is rather common in the oRATIONs. Of the three possibilities discussed, the first seems to us the most plausible, because operatio has most frequently in the ORATIONS the sense of the "inner workings of God in and through the sacred action"; and because the juxtaposition, external rite-inner effect, is one of the most frequent stylistic and expository devices used in these prayers. There is a third factor also which adds weight to this supposition. It is that firmare is used elsewhere with words denoting the action of God. The collect Pro seipso Sacerdote has: ut, quod mea voce depromitur, tua sanctificatione firmetur, $743^{1}$.

The second secret on which we should like to comment is one in which we believe actio to have a moral sense. It is that of Dom. II p. Pent.: Oblatio nos... tuo nomini dicanda purificet: et de die in diem ad caelestis vitae transferat actionem, 727 . Herz translates the second member of this prayer: "und versetze uns von Tag zu Tag in die Kulthandlung des himmlischen Lebens"; and he adds, "Mit actio caelestis vitae ist hier wohl der Vollzug der heiligen Feier gemeint, der himmlisches, göttliches Leben vermittelt"2. He is apparently led astray by the supposition that actio "in der Liturgie zumeist die Kulthandlung bedeutet", and is not sufficiently aware of the possibility that actio could have simply the moral sense. The following observations seem pertinent here. (1) Neither in the ORATIONS, nor in the earliest sacramentaries (the Veronense and the Gregorianum at least), has actio so frequently the cultic sense that this would form a cogent reason for forcing the mean-

1 The Gel. Vetus also has this prayer for the ordination of bishops: ... ut quod nostro getendum est ministerio, tua propicius virtute firmetur, MOHLBERG, 767.

${ }^{2}$ Cf. Herz, op. cit., p. 284. 
ing "Kulthandlung" on it here. (2) In five of the seven instances cited above, actio, "conduct", is used in the singular; hence the presence of the singular does not militate against the moral interpretation. (3) It seems odd indeed to pray that we may from day to day be brought into contact with the "Kulthandlung". It is more likely that we pray to grow from day to day in living the moral life which is in accordance with, and the result of the cultic action. Brou, too, interprets it here in a moral sense; and the translation by Bouman seems the apt one: "Moge... het offer... ons reinigen, en dagelijks meer brengen tot een op de hemel gerichte levenswandel".

PERAGERE, to perform a ritual action, to celebrate a feast.

The basic profane meaning of this verb is "to accomplish". Bastiaensen cites examples from pagan and from Christian authors which have this verb in a cultic sense ${ }^{3}$. In the ORATIONs it occurs once in the proper profane sense of "to accomplish". The secret Pro rege prays that the munera oblata may be beneficial to the king ad obtinendam... salutem et peragendum injunctum officium, $689^{4}$.

This verb shows in general the same tendencies as agere in the cultic sense. It stands for that which the ritual act accomplishes in its external form, in the secret for Dom. III Adv.: quae (hostia) et sacri peragat instituta mysterii, et salutare tuum in nobis mirabiliter operetur. 469 . Note that here again, even as we have seen in the case of agere $e^{5}$, the ritual action of offering (hostia) is the subject of peragat and of operetur as well. It follows that peragat means "that it may accomplish". The prefix per- may add emphasis, so as to make it mean "accomplish thoroughly"; but it may also simply represent the Late Latin tendency of prefixes to lose much of their value. Peragere would, in this latter case, be simply a stylistic variation for agere.

Twice this verb has the meaning "to celebrate a liturgical feast"; viz., in the collect of Fer. III Maj. Heb.: da nobis ita Dominicae passionis sacramenta peragere; ut indulgentiam percipere mereamur, 760 ; and that of the Octave of Easter: qui festa paschalia peregimus, 869. In this latter, the perfect tense makes clear that there is reference to the whole paschal celebration which closes with the Octave. However, we believe that it would be inadequate to translate the phrase, "having come to the

1 Cf. Brou, Les oraisons des dimanches, p. $16 \mathrm{f}$.

2 Missaal, Latijns-Nederlandse uitgave van het volledige Missale Romanum met inleidingen en verklaringen ${ }^{4}$, Utrecht 1954, p. 553.

3 op. cit., p. 70.

- G. officium, p. 106.

c C. p. $91 \mathrm{f}$. 
end of the paschal feasts"1. The word has definitely a cultic sense, since there is an obvious relationship between the celebration of the paschal feasts and the request to preserve the graces thereof in our life and conduct: haec, te largiente, moribus et vita teneamus, as the latter part of the prayer has it.

CELEbrare; see pagan Roman RELigious terms, p. $136 \mathrm{f}$.

COLERE, RECOLERE, PERCOLERE, to celebrate a feast, to commemorate officially.

For a discussion of colere see PAGAN ROMAN RELIGIOUS TERMS, p. $137 \mathrm{f}$.

Recolere occurs but 6 times in the orations. It manifests two different, though related meanings. First of all, it means "to celebrate a liturgical feast": Praesta... ut observationes sacras annua devotione recolentes, et corpore tibi placeamus, et mente, 860 . That the solemn fast of Lent and of the Ember Days was regarded as an official liturgical celebration is known²; hence the use of recolere in this collect for Fer. II p. Dom. IV Quadr. is illustrative of the meaning mentioned above. Its use has probably been influenced by the presence of the phrase, annua devotione, immediately preceding $\mathrm{it}^{3}$. The word has the same sense as celebrare, and the value of the prefix re-is weakened, but not entirely obliterated. So, too, in the two instances where the idea of commemoration is contained in the noun memoria, recolere means simply "to celebrate liturgically". These are the postcommunion for the feast of the Macchabees: quorum memoriam sacramenti participatione recolimus, 872 ; and the collect to implore the suffrage of the saints: sanctorum tuorum memoriam recolentes, 1075-4. It means "to commemorate officially", and as such refers chiefly to feasts in memory of saints: quorum (martyrum) diem passionis annua devotione recolimus, 834; dum eorum (Sancti tui) merita recolimus, 1036. In the prayer over the people for Fer. II Maj. Heb.: ad beneficia recolenda, quibus nos instaurare dignatus es, tribue venire gaudentes, 41 , there is reference to the coming celebrations in memory of the passion and death of Christ.

Percolere is used but once, namely, on the feast of St. Gregory: qui commemorationis ejus festa percolimus, 290. The prefix per- has here lost its value entirely, and the word could be substituted by colere. Since this latter is used exclusively with the nouns natalitia and solemnia in the

1 Capelle translates it: "Parvenus au terme des fêtes pascales": Les collectes des dimanches du temps pascal, QLP 14, 1929, p. 76 ff., ref. to p. 80.

Cf. observantia, p. 111.

This phrase or a similar one is found frequently with the verbs recolere, recurrere, recensere; cf. BastLaENSEN, op. cit., p. 74. 
ORATIONS ${ }^{1}$, the presence of the word festa has, no doubt, been a contributing cause at least, for the use of percolere.

COMMERCIUM, exchange.

This noun, which basically means "trade, exchange of goods", was a technical term in mercantile and legal language ${ }^{2}$. Under the Empire it had also a broader meaning which included any exchange of goods or gifts, especially New Year's gifts: cotidiana oscula edicto prohibuit, item strenarum commercium ne ultra Kal. Ian. exercetur ${ }^{3}$. St. Augustine was fond of using this term to give utterance to the fact that Christ paid for the sins of men with His Blood. It occurs only 4 times in the ORATIONs; three of these are in secrets. Indeed, it is at the offertory that the concept of exchange is most alive. In the secret of the first Mass of Christmas we have: ut... per haec sacrosancta commercia, in illius inveniamur forma in quo tecum est nostra substantia, 12. Here commercium means the human ritual action in and through which supernatural effects are produced. It is interesting to note how this magistral secret insinuates the exchange accomplished be means of the Incarnation ${ }^{4}$. The secret of Dom. IV p. Pasch. has: Deus, qui nos per hujus sacrificii veneranda commercia unius summae divinitatis participes efficisti, 409; and that of Fer. IV p. Dom. II Quadr. has: Hostias... respice, et per haec sancta commercia, vincula peccatorum nostrorum absolve, 615. In these commercium is a graphic term for the sacred ritual action. Similarly, the Eucharist is called redemptionis sacrosancta commercia ${ }^{5}, 531$, in the postcommunion for Fer. $V$ infra Oct. Pasch. because it is the "transaction" which gives man a share in redemption.

DEvotio, self-dedication to God, ritual expression of self-dedication.

In pagan cultic language this noun was the technical term especially for the act of delivering one's self and (or) the enemy to the gods of the Underworld in order to save one's country ${ }^{6}$. Cicero says: $t u$... Deciorum devotionibus placatos deos esse censes? ${ }^{7}$. It had also the transferred sense of

1 Cf. p. 138.

3 Cf. TLL III, p. $1871 \mathrm{ff}$.

3 Suet., Tib. 34; cf. Herz, op. cit., p. 14 ff.

- The first antiphon for Vespers on the octave of Christmas describes this exchange in the following striking way: $O$ admirabile commercium Creator generis humani, animatum corpus sumens, de Virgine nasci dignatus est, et procedens homo sine semine, largitus est nobis suam deitatem.

- Cf. the discussion of redemptio, p. 52 f., where can be determined how appropriately the term commercia as a "business transaction" can be applied to the Eucharistic action.

- Cf. TLL V, p. $878 \mathrm{ff}$.

' Nat. deorum 3, 15; cf. Livy 8, 9, 6, for the account of $Q$. Decius Mus. 
"dedication to the gods". The former meaning lived on in the sense of "curse"; while from the latter developed the meaning "spirit of dedication", and as such it is synonymous with fides and pietas in the ordinary profane sense of these words 1 . The material in the Thesaurus makes it evident that the word was very frequent among Christian writers, both in the profane sense of "dedication to a person" or "to one's country" and in the Christian religious sense of "dedication to God".

It seems that this Christian usage of the word, rather than the ancient pagan content, is the basis of its cultic sense in the euchology of the Church ${ }^{2}$. The pagan practice of the devotio had disappeared under the Empire and with it, naturally, the technical cultic sense of the word. Furthermore, it is a linguistic fact that a technical term of a given group language does not become a technical term in another group language without having passed through an intermediary stage of being a very general term in the ordinary colloquial speech. Given the concrete character of the language of the liturgy, it is not hard to realize that devotio in its sense of "self-dedication to God which shows itself in action" should come to be applied to the ritual action of the Eucharist. The same phenomenon can be noted in the English language, though on a more popular level. From the meaning of devotion as a "pious sentiment or attraction for a given saint or mystery" has come the popular technical term "devotions". And so we have the expressions: "St. Anthony devotions, Sacred Heart devotions, and even May devotions or Evening devotions", where the word no longer expresses a subjective attitude, but indicates concretely the prayers or other pious practices offered.

Instances where devotio is used in one or other genitive construction with words for the sacred action display the cultic sense of the term: ut per haec piae devotionis officia, ad caelestem gloriam transeamus, 1106; Suscipe... oblationem nostrae devotionis, 1133. Secret prayers often deal with the sacramental character of the sacred rites. The ascription of such sacramental power to devotio assures its cultic content in the secret for the feast of St. Stephen: ut, sicut illos passio gloriosos effecit; ita nos

1 Cf. TLL V, p. 879; Antibarbarus, I, p. 395; Rhernfelder, Kultsprache, p. 110 ff.

2 Daniels, Devotio, JLW 1, 1921, p. 40 ff., begins from the supposition that devotio, at least in the Veronense and the Gel. Vetus, is in the first place a direct christianization of the pagan technical term. He is thereby misled into exaggerating the Eucharistic sense of this word. C. Callewaert's critique on the article of Daniels is in part as follows: "Il a réuni tous les textes du Léonien où le terme est employé. Mais il nous parâit avoir fait fausse route dans le groupement et l'interprétation de ces textes". Saint Leon le Grand et les textes du Léonien, Sacris Erudiri 1, 1948, p. 52, note 2; cf. also Düria, Pietas, p. 70 ff., esp. p. 70, note 6. 
devotio reddat innocuos, 1107 ; in that of 8 Aug.: Accepta sit... nostra devotio : et eorum nobis fiat supplicatione salutaris, 8 ; and in that of the feast of the martyrs on 12 June: Sanctorum Martyrum... natalitia nobis votiva resplendeant: et, quod illis contulit excellentia sempiterna, fructibus nostrae devotionis accreseat, 1053. The fixed expression, annua devotione, for the yearly celebration of feasts ${ }^{1}$ occurs three times: et quae extrinsecus annua tribuis deootione venerari, 539; see also 834, 860, and incessabili devotione, 163. It seems justifiable also to see in: ut quod pia devotione gerimus, certa redemptione capiamus, 150, of the postcommunion for 2 July, an example of the oft-recurring rhetorical juxtaposition of the external rite to the internal effect thereof.

It is interesting to note that devotio appears a number of times in connection with the official fast ${ }^{2}$. This tendency is noticeable both in the Veronense and in the works of St. Leo. Here, as in many other instances, it is all but impossible to draw a line of demarcation between devotio as "cette disposition fondamentale de la volonté qui se met tout entière au service de Dieu"s, and that same word when used for the official fast. The two ideas fit into and overlap each other. The third collect for Sabb. Quat. Temp. Pent. has: Deus, qui ad animarum medelam, jejunii devotione castigari corpora praecepisti, 245; that of Sabb. p. Dom.IV Quadr.: Fiat... per gratiam tuam fructuosus nostrae devotionis affectus: quia tunc nobis proderunt suscepta jejunia, si tuae sint placita pietati, 562; the second collect of Fer. IV Quat. Temp. Quadr.: Devotionem populi tui... benignus intende: ut, qui per abstinentiam macerantur in corpore, per fructum boni operis reficiantur in mente, 468 . The fact that the second member is bound to the first in a relation of finality shows that devotio in this last prayer means not simply an attitude of dedication to God, but concretely the official fast which is at once the means of restraint for the body and the source of practical charity 4 . In the second collect for Fer. IV p. Dom. IV Quadr.: ut quos jejunia votiva castigant, ipsa quoque devotio sancta laetificet: ut, terrenis affectibus mitigatis, facilius caelestia capiamus, 873, we think that devotio is synonymous to jejunia. The presence of $i p s a$ quoque indicates this. While jejunium points up the personal element of fasting, devotio lays stress on its public official character. Thus castigare is used for the personal content of the jejunium; and laetificare, which is one of the verbs used regularly for the effects of a liturgical action, is employed with devotio.

1 Cf. Bastuaensen, op. cit., p. 75.

2 Cf. Brou, Les oraisons dominicales, p. 19, note 1; Gulllaume, NRTh 76, 1954, p. 243.

a Callewaert, Sacris Enudiri 1, 1948, p. 52.

- Cf. p. 182, note 3 . 
The moral sense of this word is evident in such prayers as: ut... piae nobis fructus devotionis accrescat, $846 ;$ ut... plena tibi, atque perfecta corporis et animae devotione placeamus, 55 ; respice propitius ad devotionem populi renascentis, 803 ; and 833,162 . It is juxtaposed to salus as one of the effects of the ritual celebration, and as such it expresses man's moral attitude as distinguished from grace as an objective reality: ut... solemnitas, et devotionem augeat et salutem, 187; ut et devotioni nostrae proficiant (sc. sacrificia), et saluti, 1011. In this moral connotation, it occurs a number of times with the noun affectus: Proficiat... plebs tibi dicata piae devotionis affectu, 898; ita piae devotionis erudiamur affectu1, 534; Fiat... per gratiam tuam fructuosus nostrae devotionis affectus, 562 ; et quibus devotionis praestas affectum, praebe... auditum, 1046.

By way of summary, then, we may say that devotio in the ORATIONs means both the attitude of dedication to God and the concrete expression of this attitude in the sacred rites. The collect for Dom. IV p. Pent.: Da nobis... ut et mundi cursus pacifice nobis tuo ordine dirigatur; et Ecclesia tua tranquilla devotione laetetur, 170, may serve as a representative example of how both interpretations may be included in the word. Clear expressions of the fact that the gifts and the sacred rites concretize our act of devotion, i.e. our self-dedication to God, are the secrets: Munera tibi... nostrae devotionis offerimus, 707; and Devotionis nostrae tibi... hostia jugiter immoletur, 469 . In these the brachyological genitives ${ }^{2}$ munera devotionis and devotionis hostia serve to express succinctly the idea that the gifts are the outward realization of the inner spirit of dedication.

EXHIBERE; See LEGAL TERMS, p. 153.

EXSEQUr, to perform a ritual act, to fulfill.

The cultic sense of this word derives from its meaning: aliquid persequendo vel ad finem, vel ad effectum adducere; perficere, agere. ${ }^{3}$ To give but one example: Annua vota tamen sollemnisque ordine pompas Exsequerer, Ver., Aen. 5,54. In legal language it meant ad effectum perducere ${ }^{4}$. This, too,

1 In the Vetonense (Mohleerg, 1186) and the Gel. Velus (Mohlberg, 204) this collect appears for the feast of St. Caecilia. The former has adfectus, while the latter has effectus. Dürug, Pietas, p. 74 f., holds that the reading in the Gel. Vetus is better, and he is thus able to conclude to a cultic interpretation of devotio; but he also cites five other examples from the said sacramentary where the expression devotionis affectus or its equivalent occurs $(39,40,126,278,135)$. These latter have the moral connotation. This fact, plus the whole tenor of the prayer, leads us to prefer the moral interpretation also in 534 cited above.

Cf. Merkx, op. cit., p. 20.

sLL V, p. 1849, esp. 1852.

- Cf. Heumann-Seckel, p. 417. 
may have influenced its use in the liturgy. It is in the postcommunions that it occurs with the meaning "to perform a ritual act": that of Fer. III p. Dom. I Pass.: ut quae divina sunt, jugiter exsequentes, donis mereamur caelestibus propinquare, 188; that of 20 Jan.: ut, cujus exsequimur cultum... sentiamus effectum, 963; see also 1065'; and that of Fer. V Coena Dom. ut quod tempore nostrae mortalitatis exsequimur, 964. Upon closer inspection of the use of this verb in sacramentaries, we note that its presence in postcommunions by no means necessarily indicates that it connotes "to bring the ritual action to a close", since it is used in the Gregorianum, for example, in the blessing of the font: et licet nos tantis mysteriis exsequendis simus indigni ${ }^{2}$. It occurs also in secrets, for instance: ut quod nos exsequimur minus idonea servitute, illorum potius meritis efficiatur acceptum ${ }^{3}$. Once the word refers to God's act of bringing to accomplishment what He has begun in the sacrament. The secret of Dom. XXIII p. Pent. has: ut, quod immeritis contulisti, propitius exsequaris ${ }^{4}, 893$.

Three times exsequi has reference to the fulfilment of the commandments: $u$ in exsequendis mandatis tuis, et voluntate tibi et actione placeamus, 230; ut mente et corpore pariter expediti, quae tua sunt, liberis mentibus exsequamur, 751 ; quae tibi sunt placita, et dictis exsequamur et factis, 875 . The remaining two occurences illustrate how one word may have very different meanings in different contexts; for in: ut quod a te obtinere abstinendo nititur, hoc bonis operibus exsequatur, 327, it means "to attain"; while in: ut divini operis fructum propensius exsequentes, 548 , it denotes "to search for, to seek to attain".

EXSOLVERE, to discharge an obligation.

In mercantile language exsolvere was used for "to pay a debt" 5 . It was used in the general colloquial language also in the tropical sense of "to discharge an obligation, especially a religious obligation". Thus Plautus has: ut...ea (sc. vota) ego exsolvam omnia, Amph. 3, 2, $66 \mathrm{f}$; and Livy: Hannibal... Herculi vota exsolvit, 21,21,9. It is not frequent in the sacramentaries; and this is not surprising, because the Christian religion is not wont to make bargains with God as were the ancient pagan Romans. Still it occurs twice in the Gregorianum ${ }^{6}$. The Veronense uses it twice with debitum mortis ${ }^{7}$ and once with laudes ${ }^{8}$. Its use in the secret for

1 Cf. p. 91 , note 3 .

2 Lietzmann, 19, 2; for further examples see Index Verbonum in this edition.

s Vetonense, Mohlaerg, 28.

- For further discussion, see p. 172.

- Cf. TLL V, p. 1876 ff.

- Lretzmann, 157, 2 (This one has come into the MR), and 198, 3.

2 Mohlberg, 156 and 259.

- Mohlderg, 489. 
Ss. Protus and Hyacinth is surely influenced by the presence of quae debemus: munera tibi... quae debemus, exsolvimus, 895.

FREQUENTARE, to perform a ritual action, to celebrate a liturgical feast.

This verb had, by the time of Apuleius, lost its iterative sense almost entircly. It had a cultic meaning in pagan Latin and in Christian Latin as well ${ }^{1}$. Augustine was, for example, very fond of this word, which is found with great frequency in the $D e$ civ. Dei. In the orations it occurs but 4 times. In the prayer over the people for Fer. V p. Dom. I Quadr. it means "to perform the ritual act": Da... populis christianis: et, quae profitentur, agnoscere, et caeleste munus diligere, quod frequentant, 182. It has the same sense in the much discussed secret of Dom. IX p. Pent.: Concede nobis... haec digne frequentare mysteria, 120. The noun frequentatio also fits this definition the one time that it is used: ut cum frequentatione mysterii, crescat nostrae salutis effectus, 1090. The sense of "to celebrate a liturgical feast" in the cultic act, which is the Eucharist, appears in the postcommunion of the first Mass of Christmas: qui Nativitatem Domini n.J.C. mysteriis nos frequentare gaudemus, 164 . The collect for Ss. Perpetua and Felicitas is interesting. The Veronense has the text as it is in the MR (except that it has quos): ut, quas digna mente non possumus celebrare, humilibus saltem frequentemus obsequiis, 163 . It is somewhat odd to have frequentare with a personal object and that may be the reason why the Gel. Vetus has: humilibus saltim frequentibus obsequiis veneremur ${ }^{2}$. Venerari is indeed used with a personal object in the oratrons. However, obsequium in our collect gives the idea of a ritual or liturgical celebration ${ }^{3}$, and frequentare, then comes to mean "to pay homage to". We may add that this prayer, as a whole, is an outstanding example of the artificial character of the hieratic language of the ORATIONS.

GERERE, to perform a ritual action.

Gerere displays a more static character in the orations than does agere. It occurs but once in the moral sense. This is in the collect of Dom. p. Ascen.: fac nos tibi semper et devotam gerere voluntatem, 762. All eleven other instances have the cultic designation ${ }^{4}$. And here, too, it is restricted almost entirely to mean "to perform the sacramental ritual

1 Cf. TLL VI, p. 1308 ff. esp. 1309, line 58; Bastraensen, op. cit., p. 73; Diezinger, op. cit., p. 142.

2 Mohlaerg, 844.

C. obsequium, p. 105.

- Gerere reveals the same tendency in the Veronense where only 3, of the 23 times that it occurs, have a moral sense. These are, furthermore, all in VD passages: MoHLBERG, p. 31,$21 ; 69,30 ; 44,13$. 
act". Only once does it refer to "celebrate a feast"; namely, in the collect for St. Donatus: cujus festa gerimus sentiamus auxilium, 464 . In its fuller sacramental sense, this verb occurs twice in secrets; viz., that of Dom. XVII p. Pent.: ut haec sancta, quae gerimus, et a praeteritis nos delictis exuant, et futuris, 669; and that of Fer. IV Maj. Hebd.: quod passionis Filii t.D.n. mysterio gerimus, piis affectibus consequamur, 1128. More frequently it is used in postcommunions: ut... quae pro illius veneranda gerimus passione, nobis proficiant ad medelam, 815; quae humiliter gerimus, salubriter sentiamus, 971; Sumentes... caelestia sacramenta, quaesumus... ut, quod temporaliter gerimus, aeternis gaudiis consequamur, 1075. See also 150, 817, 1076. Here again the similarity between secrets and postcommunions as to content and language is conspicuous. Mark, for example, number 1128 and 1075. Note, too, that the present tense is used in postcommunions, as well as in the secrets. All this is evidence that the rite was regarded as one single unity.

The prayer for the Benedictio fontis (2a) has: spiritum adoptionis emitte; ut, quod nostrae humilitatis gerendum est ministerio, virtutis tuae impleatur effectu, 754. That for the consecration of a bishop contains practically the same words: et, quod humilitatis nostrae gerendum est ministerio, tuae virtutis impleatur effectu, 39. In addition to these, there is the prayer for the ordination of deacons in the Gel. Vetus which also employs nearly an identical formula: ut quae [sumus] nostro sunt gerenda servitio, tuo benignus prosequaris auxilio 1 . Worthy of remark is the fact that the gerundive form is used only in these three instances. What force has the gerundive here? If it represents the Late Latin tendency to use the gerundive for a future passive participle ${ }^{2}$, then gerendum est has reference to the "consecration" of the font, or of the deacon, or of the bishop". In fact, the solemn prayer of "consecration" does follow the respective prayers mentioned above. This explanation, however, loses some of its force through the fact that these rites were, on the whole, regarded as a unity. If, on the other hand, the gerundive is seen here in its original meaning as designating an action as such, without respect to time or mood $^{3}$, then gerendum est $=$ geritur because the context demands that interpretation. This latter explanation seems the more plausible to us.

1 Mohlberg, 151.

2 Cf. Dag Norberg, Syntaktische Forschungen auf dem Gebiete des Spätlateins und des frühen Mittellateins, Uppsala 1943, p. 200; P. Persson, De origine ac vi primigenia gerundii et gerundivi latini, Uppsala 1900, p. $97 \mathrm{ff}$.

- Cf. Pentti Aalto, Untersuchungen über das lateinische Gerundium und Gerundivum, Helsinki 1949, p. 140 . 
MINISTRARE, MINISTERIUM, MINISTER, to serve God; service of God; one who performs the liturgical functions.

The verb ministrare is used in the Vulgate to translate $\lambda$ eitovereiv (Heb. 10,11); ministerium is used as a translation both of diakovia (Acts 6,4; 2 Cor. 6.4) and of $\lambda \varepsilon \iota t o v e \gamma i a$ (Heb. 8,6); and $\lambda \varepsilon \iota \tau o v e \gamma o ́ s$ (Rom.

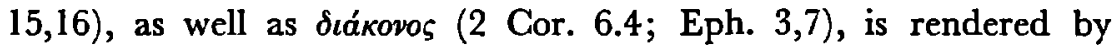
minister. These words do not occur very often in the orations; but there is a noticeable difference between the strictly "liturgical" sense and the broader interpretation of these terms as "service of God" in general. Most frequently there is reference to the special function of the ordained priest (or bishop). This is found chiefly in prayers in connection with the administration of the sacraments. Thus we have in the collect before the solemn blessing of the font, and in that of the votive Mass for the consecration of a bishop the clause: et quod humilitatis nostrae gerendum est ministerio, tuae virtutis impleatur effectu, 754, 39. In the collect for the Nuptial Mass we have: ut, quod nostro ministratur officio, tua benedictione potius impleatur, 537 . The priest prays in the collect for himself: me... dignum sacris altaribus fac ministrum, 7431 .

It is somewhat odd to have a special mention of the "ministers" of the sacred rites in a postcommunion as we have it in that of St. Donatus: Deus, qui nos sacramentorum tuorum et participes efficis et ministros, 748. It seems to fulfil a rhetorical function as the complement of participes.

The collect, In Ded. S. Mich.: Deus, qui miro ordine Angelorum ministeria hominumque dispensas: concede... ut, a quibus tibi ministrantibus in caelo semper assistitur, ab his in terra vita nostra muniatur, 387, demands a special remark. Basing his judgment on a similarity which he finds between this prayer and various texts from St. Gregory the Great, F. Vandenbroucke $^{2}$ concludes that this prayer is from the hand of the great pope himself. That may very well be. Since St. Gregory is wont to use ministrare to express the helpful services which the angels perform for mankind ${ }^{3}$, and since he makes a point of noting the difference between ministrare and adsistere in Dan. 7,104, the learned Benedictine deems it

1 This collect occurs in the Veronense (Mohlberg, 964) and the Gel. Vetus (MohlBERG, 775) as the prayer said by the bishop on the day or on the anniversary of his ordination.

2 La collecte pour la fêle de S. Michel. Son sens, son origine, QLP 25, 1940, p. $163 \mathrm{ff}$.

- The term minister for angelus is of Biblical origin, and the word ministrare was a regular term among the Fathers for the "works" of the angels. This terminology is not peculiar to St. Gregory. Cf. Chr. Mohrmann, Exultent divina mysteria, Études, $I^{2}$, p. 223 ff., esp. p. 226 ff.

- Aliud namque est ministrare, aliud adsistere, quia hi administrant Deo, qui ad nos nuntiando 
logical to apply this distinction to the second half of the collect in question; so that ministrare would have to indicate the service of the angels on behalf of mankind and adsistere the contemplative function of the heavenly spirits. That there is a reference to Dan.7,10 seems obvious; but we have to do here with an example of the liturgy's tendency not to quote Sacred Scripture directly ${ }^{1}$, but to mold allusions into a preconceived pattern of prayer. Hence it would not be necessary to conclude that the two verbs in question depend for their meaning on the sense which they have in Dan. 7,10; they simply express the action of the angels in heaven in contradistinction to their functions on earth as the protectors (muniatur) of men. Since the whole prayer emphasizes the distinction between angels and men, it is but logical to interpret ministeria in the broad sense of "duties"2.

OBSEQUIUM, religious service (here in honor of a saint).

This is one of the more general terms used especially in Post Classical and Late Latin for "religious service"s. Apuleius uses it for the pagan cult: Ut renatus quodammodo statim sacrorum obsequio desponderetur ${ }^{4}$; Tertullian employs it to designate the solemn fast of the statio: devotum obsequium eucharistia resolvit ${ }^{5}$.

In the ORATIONs it has clearly the cultic sense of "the religious service in honor of a saint", as, for instance, in the collect for 25 Oct., $u t$, quos veneramur obsequio, eorum pium jugiter experiamur auxilium, 77; and in that of 6 Mar.: ut quas digna mente non possumus celebrare, humilibus saltem frequentemus obsequiis, 163 . The request that our lives be in harmony with the ritual action is a rather usual one in the ORATIONs ${ }^{\circ}$. So, too, the collect of 12 May has: Semper nos... foveat... beata solemnitas: et tuo dignos reddat obsequio, 1062. Tuo stands here in the place of an objective genitive. The addition of the adjective sincerus makes the connotation, "respect, homage" evident in the secret for Fer. IV p. Dom. I Pass.: Annue... ut hostias placationis et laudis, sincero tibi deferamus obsequio, 53; and in the postcommunion for Dom. IV Quadr.: ut sancta tua, quibus incessanter explemur, sinceris tractemus obsequiis, 172; and in that

exeunt; adsistunt vero qui sic contemplatione intime perfruuntur, ut ad explenda foras opera minime mittantur, Hom. Evang. 2, 34, 12; cf. also Moral. 2, 3; 17, 18.

1 Cf. Mohrmann, VG 4, 1950, p. 18; points out that this same process is noticeable in the Canon Missae.

2 Cf. J. Prenn, De oratie van S. Michaël, Tijdschr. voor lit. 32, 1942, p. $87 \mathrm{ff}$.

- Cf. Forcelinim-de Vit, IV, p. 356; Dürig, Pietas, p. 71; Chr. Mohrmann, Statio, VC 7, 1953, p. 221 ff., esp. p. 225 ff.

- Met. 11, 16.

- De orat. 19,2 .

- Other prayers which ask to be "worthy" of the service are 576, 925, 554, 957. 
for the feast of St. Mary Magdalen: cujus oblationis obsequium... Filius tuus... suscepit, 697.

ofFICIUM, rite, the ministry of the hierarchy.

This noun, which for Cicero meant "duty" as well as "office"1, was under the Empire frequently used for "service to one's country", and for ceremonies and religious services as well. It is one of the words frequently used as the translation for deitoveria. Mohrmann has drawn attention to the fact that ieiunium is classified as a religious practice by its being termed an officium by Tertullian in De ieiun. $11^{3}$. The following are its usages in the orations. The external ritual which is productive of supernatural effects is designated by this noun in the postcommunion for the vigil of St. Lawrence: ut sicut... temporali gratulamur officio; ita perpetuo laetemur aspectu, 179; in that for Epiphany: ut quae solemni celebramus officio, purificatae mentis intelligentia consequamur, 862 ; and that of 10 Aug.: ut, quod debitae servitutis celebramus officio, salvationis tuae sentiamus augmentum, 1022. Once it means the "celebration" of a feast in honor of a saint: da... ut quam (Agnetem) veneramur officio, 399.

A remark about the use of the singular and plural is in place here. While the singular points to the sacred action in general, the plural emphasizes the concrete character of that action as here and now in progress. The presence of haec in the phrase which occurs three times; viz., ut per haec piae placationis officia perpetuam misericordiam consequatur, $606,906,1031$, lends weight to this assertion. And still there are stylistic devices which must also be reckoned with. For example, the striving for rime is surely at least a contributing cause for the use of the singular in: ut, quod fragili celebramus officio,... nobis prodesse sentiamus auxilio, 972.

The word has the meaning of "the special ministry of the hierarchy" in the collect, Pro Sponso et Sponsa: ut, quod nostro ministratur officio, 537; and that of the Mass, In collatione sacrorum Ordinum: ut nullis perturbationibus impediti, liberam servitutem tuis semper exhibeamus officiis, 541. Once it has the sense of "official duty of the king": et regi nostro ad obtinendam animae, corporisque salutem, et peragendum injunctum officium... proficiant, 689. Here it implies more than the ordinary profane sense of "official duty", for the kingship in the Merovingian and Carolingian times was regarded as a sacred office. It is thoroughly imbued with the idea of "king by the grace of God"4.

1 Primum oratoris officium esse dicere ad persuadendum accommodate, De orat. 1, 138.

2 Cf. E. Bernert, De vi atque usu vocabuli officii, Breslau 1930, p. 156.

- Gr. VC 7, 1953, p. 225 f.

- On the subject of the ritual for the accession of kings and emperors, see C. A. 
RECENSERE, to perform a ritual action, to celebrate a feast.

The cultic sense of this word is evident from the context in which it is used. It occurs but three times in the orations: Beati Apostoli tui Bartholomaei solemnia recensentes, 70; beatae Felicitatis... solemnia recensentes, 852; and Da nobis... unigeniti Filii tui recensita nativitate respirare, 169. In this last prayer, nativitate is clearly a "liturgical feast" in the sense in which St. Leo ${ }^{1}$ uses the term; and hence there is no difficulty in seeing that recensere ${ }^{2}$ has the same meaning in 169 as it has in the other prayers quoted.

SER VTTIUM, a cultic service.

Servitium, which in profane Latin meant "slavery, duties of slaves", has also the broader sense of "service" in general. The plural servitia was also used in Post Classical times for servi ${ }^{3}$. This noun occurs but three times in the orations. In the collect for Sabb.p. Cineres: ut hoc solemne jejunium... devoto servitio celebremus, 28 , it may be interpreted as an ablative of means, and thus be a stylistic variant for officium meaning "the official keeping of Lent". In: Suscipe... munera nostris oblata servitiis, 1125, the name of the service is used for the performers thereof and the phrase means "gifts offered by us, your servants"4. This noun was one of the words which under Biblical influence were used for "living according to the commandments of God"5, and this is its meaning in: ut... ejusdem proficiamus et fidei consortio, et digno servitio, 748, where it

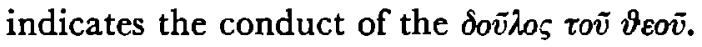

\section{Some names given to the liturgical celebration}

COMMEMORATIO, memorial celebration ${ }^{6}$.

This noun, which was rare in Classical Latin, came to have a technical sense in Christian writings. The Thesaurus defines it as follows: memoria sanctorum aliorumque fidelium defunctorum vel passionis Christi quo-

Bouman, Sacring and Crowning. The Development of the Latin Ritual for the Anointing of Kings and the Coronation of an Emperor before the Eleventh Century, Groningen 1957, passim, esp. $90 \mathrm{ff}$.

1 Cf. p. 70.

Cf. Th. Michels, Recensita Nativitate, JLW 11, 1931, p. 139 ff.

- Cf. Antibarbarus, II, p. 518.

4 Cf. Löfstedt, Kommentar, p. 112.

- Cf. Lorie, op. cit., p. 93 f.

- Cf. TLL III, p. 1829; Hippolyte Delehaye, les origines du culte des martyrs, Bruxelles 1912, p. 35 ff.; Lours Duchesne, Origines du culte chrétien 6 , Paris 1908, p. 300 ff.; F. J. DöLGer, Der heilige Fisch in den antiken Religionen und im Christentum. II, Münster in Westf., 1922, p. $549 \mathrm{ff}$. 
tannis celebranda. That the pagans also "celebrated" the memory of their dead is well known. Whether the public celebrations in memory of the martyrs and confessors was but a Christianization of the general pagan practice as Delehaye implies, 1 or if it became usual under the specific influence which the words of Christ: hoc facite in meam commemorationem $^{2}$, exercised, as Dölger maintains ${ }^{3}$, is difficult to determine. The fact is that there is evidence as early as the middle of the second century that the anniversary of the martyrdom was celebrated in order to honor those who had been victorious over death and to strengthen those who would still have to endure the combat ${ }^{4}$. There is evidence, too, that the customary Christian memorial of the dead and the Eucharistic memorial of Christ's death were related. ${ }^{5}$

In the orations the word occurs twice in a context which is obviously a variation of the Scripture text. These are: qui discipulis suis in sui commemorationem hoc fieri... monstravit, 655, and quae in tui commemorationem nos facere praeceptisti, 1083. The instance where the Eucharist is called a commemoratio, in the secret for Dom. IX p. Pent.: quoties hujus hostiae commemoratio celebratur, 120, we have treated on p. 76 .

For the most part, it is the concrete memorial celebration in honor of the saints that is indicated by this noun. The Eucharist is the primary cultic act of such celebration; hence we find phrases as: Hostias... pro sanctorum Martyrum... commemoratione deferimus, 626; quae pro beati... Apollinaris commemoratione deferimus, 980; munera, quae in... commemoratione deferimus, 984; see also $895,664,1017,961$. It is the source of public rejoicing ${ }^{6}:$ nos jugiter Sanctorum tuorum commemoratione laetificas, 668; beati Laurentii Martyris tui commemoratione, temporali gratulamur officio, 179.

FESTA, a religious feast ${ }^{\text {? }}$.

This neuter substantive, for the more classical dies festus, was rare before Christian times. Nor is it a Biblical word, for it occurs only four times in the Vulgate ${ }^{8}$. Among Christian authors it is found frequently as the designation for both Christian and Jewish feasts.

1 op. cit., 36.

Lk. 22, 19; 1 Cor. 11, 24-25.

s Op. cit., p. $551 \mathrm{f}$.

Cf. Mart. Polycarpi 18, 3.

- Cf. Dölger, Der heilige Fisch, II, p. 551, points out, for example, how John Chrysostom in his In epist. 1 Cor. Homil. 27, 4, mentions the two in the same breath.

- Cf. Odo Casel, Zur Idee der liturgischen Festfeier, JLW 3, 1923, p. 93 ff.

7 Cf. TLL VI, 1, p. 626 ff.; Antibarbarus, I, p. 536.

- It is interesting to note that in the Vulgate, solemnitas occurs $59 \times$, festivitas $15 \times$, festus dies $36 \times$, and festa $4 \times$. 
In the ORATIONs it occurs with the usual words meaning "to perform a ritual action" agere, 135, 411; peragere, 869 ; gerere, 464 ; celebrare, 529 ; percolere, 290; sectari, 555 . In these examples festa is the object of the verb and hence it is itself "that which is ritually performed". It is, in this sense, productive of supernatural results, as the collect for Fer. IV infra Oct. Pasch. clearly shows: ut per temporalia festa quae agimus, pervenire ad gaudia aeterna mereamur, 411. So also, when the festa is regarded an active concept, it is seen as a source of grace: Beatorum Martyrum... nos... festa tueantur, 75.

FESTIVITAS, festal celebration ${ }^{1}$.

In its earliest usage this noun meant "pleasantness, cheer". Since these are the moods proper to a festival day, the word acquired the meaning of "festivity". This is its sense in the orations. Twice festivitas is visualized as an active cause of grace: Sancti Joannis... veneranda festivitas: salutaris auxilii praestet effectum, 1032; jucundos facias suae interesse festivitati, 460. The other instances approach more closely the very concrete sense of "feast", but the ritual content is by no means lost. The oblatio takes on a particular color from the festivitas of which it is a part, as the request in the secret of the first Christmas Mass demonstrates: Accepta tibi sit... hodiernae festivitatis oblatio: ut... per haec sacrosancta commercia, in illius inveniamur forma, in quo tecum est nostra substantia, 12. There is an obvious relation between the hodiernae festivitatis oblatio and the request that we be "made like unto Him in whom our nature is united with God". When the construction with pro is used, as in: munera altaribus tuis pro sanctarum... tuarum... festivitate proposita, 650 , pro cujus festivitate percepimus tua sancta laetantes, 71 ; ut et tibi gratae sint pro tuorum festivitate Sanctorum, 882, it seems that the final or causal idea of the preposition needs to be retained ${ }^{2}$, because the feast is not only the occasion on which the Eucharist is offered. But contrariwise, the Eucharist helps to make the "feast" since it constitutes the essential cultic act of the festivitas. See also 842, 978. That the term is not a purely temporal concept, but includes the notion of an active celebration, is made clear also in the collect for the feast of St. Bartholomew: Deus, qui hujus diei venerandam sanctamque laetitiam in beati Apostoli tui Bartholomaei festivitate tribuisti, 782, where in festivitate means not "on the occasion of", but "in the festal celebration". This ritual connotation is apparent again in the collect for Ss. John and Paul: ut nos geminata

1 Cf. TLL VI, 1, p. 623 ff.; Antibarbarus, I, p. 536; Goelzer, op. cit., p. 260.

2 Note the same phenomenon in English. If we say, "I received this ring on my birthday", the final element is stronger than the temporal in the phrase, "on my birthday". Compare it with the sentence, "I received this ring on 12 September." 
laetitia hodiernae festivitatis excipiat, 943 , for the festivitas is the source of the laetitia. Similar to this are the following: beati Andreae Apostoli festivitate laetantes, 1079; and de beatae... virginis tuae festivitate gaudemus, 534. Only once is this noun used as the object of the verb celebrare: ut cujus venerandam celebramus festivitatem, 225.

The classical term for "celebrating a feast in great numbers" celebratio also occurs a few times in the same sense that festivitas has: sub una tribuisti celebritate venerari, 792; Fiat tibi... hostia sacranda placabilis, pretiosi celebritate martyrii, 563 ; Sumpsimus... celebritatis annuae votiva sacramenta, 1078.

HONOR, homage, cultic action, festal celebration'.

This noun, which contains not only the sentiment of respect and reverence, but also the concrete expression of this attitude, was used by both pagan and Christian authors for "cult". In the orations, too, it is usually found in this concrete sense. When, for example, we find in the secret for the Birth of St. John the Baptist: nativitatem honore debito celebrantes, 1143 ; in the postcommunion of the first Sunday of Advent: reparationis nostrae ventura solemnia... honoribus praecedamus, 1135; or in the collect for the votive Mass of the Holy Cross: qui... sanctae Crucis gaudent honore, 454, we have no difficulty in seeing in the word honor our sentiments of respect and adoration translated into a particular cultic action. Furthermore, its use is very much like that of solemnitas or festivitas ${ }^{2}$. Note the following: quae (munera) in ${ }^{3}$ sanctorum tuonum... honore deferimus, 119; quas in honore Sanctorum... celebrat, 616; in cujus honore solemniter exhibetur, 1015; Mysteria tua... pro sanctorum... honore... tractemus, 716 ; see also $13,726,707,839,984$. In these, too, honor includes the external manifestation of esteem, which is the festal celebration.

In addition to its ritual sense, honor also occurs in the form of a doxology: ad majestatis tuae honorem, 383; ad honorem nominis tui, 901, 1137; tuo nomini dent honorem, 619; pro tui nominis honore, 653.

NATALITIA, anniversary celebration in honor of the death of a martyr; birthday.

The vox media, "annual celebration", which developed from natalitium = "birthday", in its turn, took on a technical sense in Christian Latin. "Die spezifisch christliche Begriffensentwicklung liegt in nata-

1 Cf. TLL VI, p. 2916 ff.; DE Soos, op. cit., p. 37 ff., 135; BastaAensen, op. cit., 156 ff.

2 Cf. p. 113 f. and p. 109 f..

3 The Gel. Vetus (Mohlbero, 894) has pro here instead of in. 
licia $=$ Sterbtag"'. In the concrete language of the liturgy, the word receives a cultic character. This can be determined by the fact that it is used as the object of colere, 190, 376, 400, 403, 863, 864; and of celebrare, 165,847 - both verbs having a full ritual content. The plural also adds to the concrete sense of the word ${ }^{2}$.

Natalitia has the same general sense as solemnitas or festivitas only in the following: quae (hostia) in natalitiis sanctorum Martyrum... immolatur, 824; natalitiis gloriemur, 56; Sanctorum Martyrum... natalitia nobis votiva resplendeant, 1053; see also 402, 719 .

When the word is used for "birthday" in the secret for the Vigil of Christmas: adoranda Filii tui natalitia praevenimus, 177, this may represent an archaizing tendency, or it may simply be a stylization employed because natalitia has more of a cultic flavor than has Natalis, the technical name for the feast of the Nativity in the West. ${ }^{3}$

OBSERVANTIA, OBSERVATIO, rite, the observance of Lent or of the official fast of the Ember Days. ${ }^{4}$

The proper meaning of observantia is "respect, especially for a person", but is was used also for "observance of the law". From this latter, there developed the more restricted meaning, "the performance of religious duties, zeal". It is but one step further, then, to the concrete sense of "rite". Carton draws attention to the fact that observantia occurs in the Gel. Vetus as rite in a generic sense, for example: ut observantia temporalis ad vitam proficiat sempiternam ${ }^{5}$. St. Leo uses it most frequently in a specific sense for the cultic fast of Lent and of the Ember Days, and it is in this more limited meaning that it occurs in the present MR. But if the word has lost some of its broad application, it has, nevertheless, retained its sacramental character. It designates an outward rite which is productive of an internal, supernatural effect. This could hardly be more plainly stated than it is in the secret for Sabb. Quat. Temp. Quadr.: jejunia nostra sanctifica: ut, quod observantia nostra profitetur extrinsecus, inte-

1 Cf. Schrijnen, Uit het Leven der Oude Kerk, p. 70 f.; Mohrmann, Sondersprache, p. $129 \mathrm{f}$.

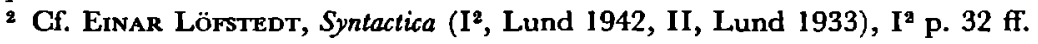

3 Cf. ENGels, op. cit., p. 71 . In other instances when there is a matter of celebrating a birthday, the word Nativitas is the technical expression, whether it be for the "birthday" of Our Lord, 131, 139, 164, 169, 631, 689, 723; of Mary, 1167; or of St. John the Baptist, 436, 1143.

" Cf. Blaise, Dictionnaire, p. 567; Icn. Carton, Notes sur l'emploi du mot "observantia" dans les homélies de St. Léon, VC 8, 1954, p. $104 \mathrm{ff}$.

5 Mohlberg, 474. 
rius operetur, 832 . The ritual element is not so clearly expressed in the other instances, but the word does stand for the official Lenten practice. Thus it is called the observantia quadragesimalis, 1012; and in the collect for Fer. VI p. Cineres, we pray: ut observantiam quam corporaliter exhibemus, 643; and in that for Fer. III p. Dom. II Quadr.: Perfice... in nobis observantiae sanctae subsidium, 816.

Observatio, which Ernout-Meillet says was often confused with observantia since the time of the Empire, is also used for the official fast. There is mention of sacrae observationes 860, 989, in the collects for Fer. II and for Fer. III p. Dom. IV Quadr. Its sacramental character is also revealed in the collect for the first Sunday of Lent, where observatio is regarded as the outward means whereby God purifies His Church: Deus, qui Ecclesiam tuam annua quadragesimali obseroatione purificas, 327.

SOLEMNIS, SOLEMNIA, a solemn, a ritual celebration, usually in honor of a saint; a feast.

The adjective solemnis means "annual", and it was applied in pagan Latin especially to religious feasts and the games'. The grammarian Festus gives this definition of it: Sollemnia sacra dicuntur quae certis temporibus annisque fieri solent ${ }^{3}$. Thus, the religious element is predominant. Tertullian has: quomodo dominica sollemnia celebrabimust? and again: post transacta sollemnia dimissa plebe ${ }^{5}$. In these last two citations, sollemnia stands for the ritual action. Such is its use also in the orations, for it occurs almost exclusively as the object of one of the verbs standing for the performance of the ritual act; viz., agere, 128; colere, 189, 191, 787, 870 ; celebrare $930,1060,1061,1075-2,1180$; recensere, 70,852 . To be noted also is the fact that solemnia in all of these instances refers to the concrete ritual action which is performed in honor of a saint; for example: beatae Anastasiae... solemnia, 189; beatorum Martynum... solemnia, 191 , etc.

In only two instances; viz., when solemnia is applied to the feast of Christmas in the postcommunion of the first Sunday of Advent: reparationis nostrae ventura solemnia... praecedamus, 1135; and to the Nativity

1 Cf. A. Ennout-A. Meillet, Dictionnaire étymologique de la langue latine. Histoire des mots, Paris 1959, p. 892.

Cf. Antibarbarus, II, p. 533; cf. Ernout-Meillet, op. cit., p. 633. The spelling with -ll-is original. According to ERnout-MerLeEt, the first half of this word comes from sollus, which Festus declares to be Oscan for "entire". Cf. also Sommer, op. cit., p. 220, 232.

Cf. Antibarbarus, II, p. 533.

4 De fuga 14.

- De anima 9. 
of Mary in the secret for 8 September: in Nativitatis ejus solemniis... oblationem... faciat acceptam, 1167, has it the same meaning which solemnitas usually has in the ORATIONS.

The original sense of "customary", "annual"1, is retained in solemnia in the collect for Ash Wednesday: ut jejuniorum veneranda solemnia, et congrua pietate suscipiant, 833, where, together with the genitive of definition jejuniorum, it means "customary fast". The adjective also occurs in the following: quae solemni celebramus officio, 862; Repleti... benedictione solemni, 973; and solemne tibi deferre jejunium, 1171 . And if we translate it here by "solemn", we are aware that the English word, too, means "pertaining to the ceremony of the liturgy".

SOLEMNITAs, festal celebration. ${ }^{2}$

This Late Latin word (one which occurs very frequently in the Vulgate $)^{3}$, falls into an entirely different pattern in the ORATIONs than that formed by solemnia. We have here to do with quite another sort of development. Solemnitas is not "that which is cultically performed", but a liturgical celebration as a whole. Sometimes it is represented as an "occasion", an essential part of which is the offering of prayers and the Eucharist: pro quorum solemnitate (devotio) defertur, 8 ; munera... pro... solemnitate deferimus, 688; munera in... solemnitate deferimus, 1109; see also 74 ; preces (supplicationes) in solemnitate deferimus, $540,31^{4}$.

Unlike solemnia, then, this noun is an active concept, seen as productive of supernatural effects. Examples of this are the following: Conferat nobis... Joannis Baptistae solemnitas ut... gaudeamus, 142; veneranda solemnitas et devotionem nobis augeat et salutem, 187. Further there is requested that the solemnitas may: pacis tribuat incrementum, 559; subsidia conferat, 874 ; indulgentiam... acquirat, 949 ; nos reddat acceptos, 1031 ; nos... foveat, 1062; magnificet te, 667 . As a liturgical celebration it is the means whereby God heals the world, as the collect for Fer. II infra Oct. Pasch. has it: Deus, qui solemnitate paschali, mundo remedia contulisti, 448.

Two further details in connection with the use of this word are worthy of mention. One is that the adjective annua is used some six times to modify solemnitas. Hence the concept of "regularly recurring" is not contained in this noun. The second item is that some verbs expressing the concept of joy or rejoicing are used with it. Here we

1 E.g. Cic., Ad Att. 7, 6, 1.

Cf. Antibarbarus, II, p. 533; Goelzer, op. cit., p. 104.

- Cf. Dutripon, op. cit., p. 1293; see also p. 108, note 8 .

- It is stylistically interesting to note that deferre is used in all these instances; this is another indication that certain words were wont to be used together in the language of the liturgy. 
have, then, the basic content of the word as the synonym of the more classical celebritas or celebratio. Solemnitas is essentially public rejoicing: nos... solemnitas laetificet, 56; or the means by which God grants such public joy: nos annua... solemnitate laetificas, 399, 400, 405, 411, 398; benedictio... de Martyrum nos solemnitate laetificet, 1095; see also $190^{1}$. It does not occur in the ORATIONs as the object of the usual words for "to perform a ritual act"; however, the distinction between solemnia and solemnitas was not always too sharp. For we do find celebrata solemnitas, 949; and in the collect which, until the recent rearrangement of the MR, was said before the blessing of the font on the Vigil of Pentecost, solemnitas appears in the construction which is usual for solemnia: qui solemnitatem doni Sancti Spiritus colimus, 138.

VENERATIO; See PAGAN ROMAN RELIGIOUS TERMS, p. $150 \mathrm{f}$.

\section{PRAYER TERMS}

The orations are, for the most part, conclusions to periods of silent prayer at the close of three high points in the liturgical act - Introit, Offertory and Communion. They are largely, though not exclusively, prayers of petition. The purpose of this section is to investigate which words are employed to convey the concept of "to pray" or "prayer", in this part of the official euchology of the Latin Church.

CLAMARE, to call upon God for help's

The proper meaning of clamare is "to speak with a loud voice". This verb is one of the usual terms employed in the Vulgate for calling upon God. From the contexts in which it appears in the orations, it can be noted that the word retains the connotation of calling for help in difficulty: Ad te nos... clamantes... qui juste pro peccatis nostris affigimur, 22; ex quacumque tribulatione ad te clamaverint, $380 ; 766 ;$ Ne despicias... populum tuum in affictione clamantem, 720.

DEPRECARI, to prays.

St. Augustine says in regard to this verb: Precari... esse precando bona optare, imprecari, mala,... deprecari... mala precando depellere ${ }^{4}$. His definition retains, thus, the full value of the prepositional suffix. In Late Latin,

1 Cf. Bastiaensen, op. cit., p. $152 \mathrm{ff}$. for a discussion of laetitia in the sense of "allegresse publique"; esp. p. 153, where he says: "Il n'y a pas loin de la joie publique à la notion de fête publique". See also Casel, JLW 3, 1923, p. $93 \mathrm{ff}$.

${ }^{2}$ Cf. TLL III, p. 1250.

3 Cf. TLL V, p. 598 ff.; G. Appel, De Romanorum precationibus, Giessen 1909, p. 66.

- Epist. 149, 13. 
however, the force of the preposition was very much weakened so that deprecari came to be synonymous with precari ${ }^{1}$, with little or no connotation of "to ward off"'. It is employed in this very general sense twice in the orations; viz., in the prayer over the people for Sabb. p. Dom. I Pass.: Tueatur... dextera tua populum deprecantem, 1154; and in the collect for the dedication of a Church: omnes, qui huc deprecaturi conveniunt, 380 . Usually, though, the word is employed in the sense of prayer of petition. This is evident from the fact that it is, in nearly every instance, complemented by an $u t$-final clause. In the secret, Ad repellendas tempestates, which gives succinctly the whole burden of Christian prayer, the meaning of deprecari is effectively emphasized by its being juxtaposed to gratias referentes: Offerimus tibi... laudes et munera, pro concessis beneficiis gratias referentes, et pro concedendis semper suppliciter deprecantes, 739 . Twice the idea of intercession is conveyed by this verb: deprecantibus sanctis, 80 ; pro quibus tuam deprecamur clementiam, 312.

The weakening of the prepositional suffix is compensated by the addition of supplices or suppliciter: supplices... deprecamur, ut..., 72; majestatem tuam suppliciter deprecamur, 381; see also 104, 623, 626, 644, 669, 781, 906, 961, 970, 1022, 1041, 1076'.

\section{DEPRECATTO, prayer.}

Like the verb from which it is formed, this noun, too, has lost, at least to a great extent, the connotation of "warding off". However, the presence of placatus suggests something of that idea in: pia jejunantium deprecatione placatus, 794. It is simply a "prayer of petition" in: Deprecationem nostram... benignus exaudi, 197. In the remaining three instances it stands for the intercession of the saints: Protegat... populum tuum et participatio caelestis indulta convivii, et deprecatio collata Sanctonum, 916; see also 728, 932.

FLAGITARE, to implore earnestly ${ }^{5}$.

This verb, which in profane Latin had the sense of "to demand", occurs but once in the orations, and that obviously because its unusual and emphatic character harmonizes perfectly with the affected tenor of the prayer for the blessing of ashes: serenissimam pietatem tuam suppliciter obnixeque flagitantibus, 769.

1 N.B. The word precari does not appear at all in the prayers under consideration.

2 Cf. TLL V, p. 600 ff.; Bonnet, op. cit., p. 229; Goelzer, op. cit., p. 267.

s Cf. supplex, p. 148 f., and suppliciter, p. 150.

- Cf. TLL V, 1, p. $596 \mathrm{ff}$.

- Gf. TLL VI, $843 \mathrm{ff}$. 
GRATIAS AGERE, GRATIARUM ACTIO; see agere, actio, p. $92 \mathrm{f}$.

IMPLORARE, to pray urgently for ${ }^{1}$.

In the strict classical sense this verb means "to call upon the gods with tears in order to arouse their pity"', but the word had a more general sense also. In the OrATIONs it is an emphatic word meaning "to ask for". Curiously enough, misericordia, 219, misericordiae auxilium, 804, clementia, 909, indulgentia, 647, 1055, appear as its object, and hence implorare seems to have retained some of its classical flavor. However, it may be that it is used simply because it is an emphatic word. It is an expression of petition, as can also be seen from the fact that it is employed with the ut-final clause: Imploramus... clementiam tuam, ut... praeparent, 639; suppliciter imploramus: ut... prodesse sentiamus, 972. A good example of the artificial character of the language of these prayers is the postcommunion for 11 Sept.: Ut percepta nos... tua sancta purificent : beatorum Martyrum tuorum... imploret oratio, 1173 . Once implorare replaces invocare in the traditional phrase: omnibus nomen sanctum tuum... implorantibus, 769.

INTERCEDERE, INTERCESSIO; SEe LEGAL TERMS, P. $157 \mathrm{f}$.

INTERVENIRE, INTERVENTIO; SEe LEGAL TERMS, P. $160 \mathrm{f}$.

INVOCARE, to call upon ${ }^{3}$.

The phrase invocare nomen Domini is a frequent one in both the OT and the NT. In the OT it has the general sense of "to call upon God in prayer", and also the specific sense of "to recognize Jahweh as the true God". In the NT the Christians designate themselves as "those who call upon the Name of the Lord", that is, those who recognize Christ as the Lord ${ }^{5}$. The one instance in which invocare occurs in the ORATIONs, is an allusion to the fact that the church is a "house of prayer", and the verb itself then means "to pray": effunde super hanc orationis domum benedictionem tuam: ut ab omnibus in ea invocantibus nomen tuum, 439.

INVOCATIO, prayer, invocation?.

This nomen actionis, too, has in the orations the Christian sense of prayer. It occurs three times in the ORATIONs: adesto propitius invocatio-

1 Cf. TLL VII, p. 645.

2 Cf. APpel, op. cit., p. 65.

${ }^{3}$ Cf. TLL VII, p. $254 \mathrm{ff}$.

- Cf. for example, Acts 9, 14 \& 21; 22, 16; 1 Cor. 1, 2; 2 Tim. 2, 22.

- Cr. La Sainte Bible traduite en français sous la direction de l'École Biblique de Jérusalem, Paris 1956, p. 1439, note f.

- Cf. p. 57 , notes 3 \& 4 .

7 Cr. TLL VII, p. $252 \mathrm{ff}$. 
nibus nostris, 230; Sanctifica... per tui sancti nominis invocationem hujus oblationis hostiam, 1039; praesta per invocationem sanctissimi nominis tui, 769.

OBSECRARE, to beseech ${ }^{1}$.

Though in the pagan Roman religious language this verb has the special sense of "by means of sacred rites to move the gods to grant favors", still the word was early used also in a profane sense of "to entreat with urgency". It occurs but once in the orations, no doubt for effect, because it is an emphatic word: preces effundimus: obsecrantes; ut... indulgeas, 1097.

ORARE, to pray.

Although this word may have been chosen by the Early Christians as the usual Latin term for "to pray to God", because it had almost disappeared from the common language and thus could claim a more or less solemn nuance ${ }^{2}$, still it became so common in the colloquial Christian language that it lost its lofty character. This popular status of the word is, no doubt, the foremost reason for its being employed so rarely in the orations ${ }^{3}$. Actually it occurs but once: qui propriis oramus absolvi delictis, 605 . The verb orare has been retained in the invitation to prayer, either alone, in the hortatory subjunctive, Oremus, of the short form, or in the place of emphasis at the beginning of the longer formulae before the Orationes Solemnes. This phenomenon may help to explain why it is absent from the body of the prayers themselves. The fact that oratio, which had as much a popular character as did the verb, has found its way into the prayers lends weight to this supposition. For even though the nomen actionis became the technical name for these prayers in the MSS", still as a "title" it was not heard during the liturgy itself as Oremus was.

ORATIO, prayer.

This noun may be considered the nomen actionis of the colloquial Early Christian term orare = "to pray", and it seems not to contain any nuance of the profane word oratio = "public speech"

1 Cf. APPel, op. cit., p. 66; RheInfelder, Kultsprache, p. 58; J. B. HofmanN, Lateinische Umgangsspraches, Heidelberg 1951, p. $131 \mathrm{f}$.

2 Cf. LöfsTedT, Kommentar, p. 463.

3 G. Mohrmann, Etudes, I2, p. 157; II, p. 104, 114; Liturgical Latin, p. 74 ff.

- Cf. oratio, below.

s Cf. p. 140 , note 6 .

- Jungmann, Missarum Sollemnia 5 , I, p. 462, suggests that the word oratio, when it is applied to these public prayers pronounced by the celebrant in the name of the people, is related to the Classical word oratio = "public speech". This supposition has been amply refuted by Professor Mohrmann in Liturgical Latin, p. $74 \mathrm{f}$. 
of the technical sense of this word is the fact that in later recensions of the Ordo Romanus $I$, the prayers which now appear in the MR as Oratio and Postcommunio, were entitled oratio prima and oratio ad complendam 1 .

Oratio occurs some 18 times in the prayers under consideration. Sometimes it means "prayer" in a broad and general sense, as for example in: ut cuncta nostra oratio et operatio a te semper incipiat, 18, or when it is paired with fasting as one of the "works" peculiar to Lent: ut jejuniis et orationibus convenienter intenti, 837, or again when it occurs in the Biblical allusion: hanc orationis domum, $439^{2}$. It is specifically "prayer of petition" in: et adjicias quod oratio non praesumit, 770 ; suscipe... orationem nostram, et libera eos, 790.

In the remaining instances it stands for prayer of intercession. It may indicate the prayers of the faithful on earth on behalf of the departed: animabus... famulorum... oratio proficiat supplicantium, 52 ; quos in oratione commendatos suscepimus, 209; or it may represent the intercession of the saints for the Church on earth: Beatorum Martyrum... adsit nobis oratio, 77; nobis ejus non desit oratio, 1043; see also 73, 297, 930, 1057, 1173. It occurs with the legal term commendare: nos... eorum commendet oratio veneranda, 75; Munera nostra... Dei Genetricis commendet oratio, 692; 1108; preces et hostias beati Petri Apostoli commendet oratio, 516; Note how the sacrificial character of preces ${ }^{3}$ and the legal connotation of oratio are patent in this last citation.

EXORARE, to obtain by prayer, to pray, to implore 4

Twice this compound occurs in the ORATIONs in its proper sense of "to pray effectively" or "to obtain by prayer": et fragilitati nostrae subsidium dignanter exoret, 1058; Beatae Mariae Magdalenae... suffragiis adjuvemur: cujus precibus exoratus... Lazarum vivum... resuscitasti, 68 . Once it is used with the accusative of the person addressed and the preposition

1 Cf. Mraher Andreu, Les Ordines Romani du haut moyen âge (I-V, Louvain, 19311961), II, p. 84 and 107 respectively. The titles super oblata and ad completa appear in the Gregorian type of sacramentaries. The terms collecta, secreta and postcommunio are also of early origin. B. CAPELle, Collecta, RB 42, 1930, p. $197 \mathrm{ff}$., points out that collecto in the sense of "prayer" is of Gallican origin, and that it was preceded by collectio in the Gallican sacramentaries where, in the 7th and 8th centuries, this latter word was the official and traditional term for liturgical prayer. Secreta and postcommunio are found in the Gel. Vetus as well as in the other Gelasian type of sacramentariers. For further discussion of these titles see Jungmann, Missarum Sollemnia ${ }^{5}$, I, 462 f., II, p. 112 ff., $520 \mathrm{ff}$.

Cf. p. 57 , note 4 .

C. p. $151 \mathrm{f}$. and 118.

4 Cf. TLL II, p. 1584 ff. 
pro - a construction which was rather frequent in Christian authors. This is in the collect for the feast of St. Stephen: qui novit etiam pro persecutoribus exorare Dominum nostrum Jesum Christum Filium tuum, 165. For the rest, it follows the general trend which is noticeable in the works of later authors; viz., the meaning lies only in the act "to pray" and has nothing to do with the granting of the petition. As in later authors the verb is in turn often strengthened by such adverbs as suppliciter, ferventer, fideliter ; $^{1}$ so here, too, the weakening of the preposition is compensated by the addition of supplices or suppliciter, and we have the phrases : supplices exoramus, ut, 208, 220, 668, 765, 794, 802, 961-2, 10262 ; or suppliciter exoramus, ut, 625, 670, 815.

PETERE, to petition, to ask for in prayer ${ }^{2}$.

A rather colloquial word for "to pray" the orations. It is used with the accusative of the thing desired: quod fideliter petimus, efficaciter consequamur, 461, 903; petentibus desiderata concedas, 807; quisquis... beneficia petiturus, 392; or absolutely: Cunctis petentibus aures... accomodes, 941 . Once it is employed with an ut-final clause, in the pleonasm: deprecamur et petimus, ut, 1041.

The compound, expetere (in the two instances that it occurs) means "to desire earnestly, to seek", rather than "to pray". It is used in reference to the catechumens: qui (populus), sicut cervus, aquarum tuarum expetit, 803; and to the bride: quae... tua se expetit protectione muniri, 434.

PETTTIO, a prayer of petition.

This nomen actionis occurs but once, and that, no doubt, for the sake of alliteration: concede plebi tuae piae petitionis effectum, 264.

POSCERE, to beg earnestly.

This verb, too, has lost much of the sharpness of its definition as it is used in the ORATIONS, where it means simply "to ask for in prayer": qui tua per eum beneficia poscimus, 401 ; Perpetuam benignitatem largire poscentibus, 23; Beati Joannis... oratio... poscat nobis fore placatum, 73 . In the last two instances the striving for alliteration was surely a contributing cause for the choice of this word.

The compound, deposcere, which was rare in Classical times, was more frequent in Late Latin ${ }^{4}$. It, too, occurs but once, and then in a very broad sense of "to ask for": hostias... sanctus $\mathcal{N}$. Abbas... in salutem nobis provenire deposcat, 1019.

1 Cf. BONNET, op. cit., p. 231, esp. note 2.

- Cf. Mohrmann, Etudes, II, p. 104; Appez, op. cit., p. 39.

3 C. p. 157, note 4.

- Cf. TLL V, p. 589 ff. 
POSTUlARE, to ask for in prayer ${ }^{1}$.

The proper sense of postulare "to demand by right", is lost when this word is used in Christian prayer. It means simply "to pray for" in the three instances that it occurs in the ORATIONs: fac eos, quae tibi sunt placita postulare, 807 ; quae digne postulant, consequi mereantur, 880; et postulata concedas, 899.

Postulatio, prayer.

This is one of the synonyms for prayer mentioned in $1 \mathrm{Tim} .2,1: O b$ secro igitur primum omnium fieri obsecrationes, orationes, postulationes, gratiarum actiones pro omnibus hominibus. But it is only here and in Ps. 118, 170, that it occurs in the Vulgate ${ }^{2}$. It was rarely used for Christian prayer. It appears but twice in the orations: once as "prayer of intercession": digna postulatione Sanctorum, 671 ; the second time as a synonym of votum in the complementary parallelism: ut nullius sit irritum votum, nullius vacua postulatio, 903.

PRECES; See Pagan roman Religious terms, p. $140 \mathrm{ff}$.

QUAESUMUS, we beseech.

The verb quaeso seems to be one of the oldest elements of Roman prayer. It occurs in the pleonastic construction precor quaesoque in the ancient formula of prayer recorded by Cato: Mars pater, te precor quaesoque, uti sies volens propitius mihi ${ }^{3}$; and in those set down by Livy in 8.8 , and $29,27,1^{4}$. Hofmann remarks that already with Plautus it began to be something of a fixed expression by reason of its enclitic position. It was frequently used to affect an imperative: dic, dic quaeso clarius $^{6}$; or to soften it and make it more of an entreaty: Sin tibi quid venti in mentem scribe quaeso ${ }^{7}$. With an $u t$-clause it is rare outside Early Latin except for fixed sacral expressions and in the affected speech of some rhetoricians. Thus, it early ceased to be a living element of the colloquial language. Jerome employed it frequently in the Vulgate ${ }^{\theta}$.

Its stylized character, then, makes it a fit element for the elevated

1 Cr. Blaise, Dictionnaire, p. 759.

2 Cf. Dutrupon, op. cit., p. 1098.

- De agr, 141, 2.

1 Cf. also the prayer composed by Augustus in the year 17 B.C. where the order of words is reversed, quacso precorque, CIL VI 32323, vv. 92, 105, 117, 121, 136, 141, See also ApPel, op. cit., p. 10 and 66.

s Hofmann, op. cit., p. 128 f., quotes from Plautus the following: quiesce quaeso, Asin. 418; milte quaeso, ibid. 596; sine quaeso, Pers, 688.

- Cic., Verr. 2, 143; 4, 167.

- Cic., Ad Att. 15, 51.

B Cf. Dutripon, op. cit., p. 1147. 
tone of the ORATIONS, where it appears only in the form quaesumus. It does occur with a complementary $u t$-final clause, and hence as the principal verb of prayer, in about $10 \%$ (37 of the $\pm 360 \times$ ) of the instances. In these cases it is usually placed at the beginning of the prayer and is followed by the solemn vocative Omnipotens Deus. It is a general linguistic principle that the place immediately following the first word (or group of words, when this is small and closely knit) is one of weak emphasis ${ }^{1}$; and such words are placed there as are originally enclitic or can become so by reason of being in that position. Quaesumus belongs to the former category. Hence we find it in combinations as: Concede, quaesumus Domine; Da, quaesumus, or Da nobis, quaesumus; Tribue, quaesumus; Praesta, quaesumus. In these cases it fulfills a double role. On the one hand it contributes to the rhythm of the prayers since it is an unaccented element following one which bears the ictus. On the other hand it serves to soften the imperative which man really has no right to utter before God.

ROGARE, to ask for ${ }^{2}$.

This verb, which was an Early Christian colloquial term for "to pray", occurs in but one fixed expression in the ORATIONs: supplices te rogamus, 101, 382, 1099, 1100, $1103^{3}$.

SUFFraGiUM, SUFFragari; See LEGAL TERMS, p. $172 \mathrm{f}$.

SUPPLicare, SUPPLIGATIO; SEe PAGAN ROMAN RELIGIOUS TERMS, P. $149 \mathrm{f}$. votum, prayer 4 .

This noun came, by the fourth century, to be one of the synonyms for "prayer". It is thus that it occurs also in the orations. This is clear in the following: vota nostra, quae praeveniendo aspiras, etiam adjuvando prosequere, 350; et merita supplicum excedis et vota, 770; vota humilium respice, $950 ;$ vata... prosequere, 1179,1181 ; see also 127,903 . The language of the liturgy is never abstract. The terms used for prayer are no exception to this general trend. The ancient collect, now used for the martyrs on $29 \mathrm{July}$ is a fine example of this concreteness; for votum here stands for the prayers which constitute, in a large part at least, the celebration which is here and now in progress: quod votis celebrat, comprehendat effectu, 848. Its meaning as "prayer" is also effectively conveyed by its

1 Cf. Havers, op. cit., p. 397 ff., esp. 399 f.

Cf. Mohrmann, Etudes, II, p. 104; DiehL, op. cit., III, p. 398.

Cf. p. 149.

- Cf. Blaise, Dictionnaire, p. 860; Botte-Mohrmann, op. cit., p. 77, note 6; Antibarbarus, II, p. 686. 
being set over against sacramentorum in the postcommunion for the dedication of a church, which in one clause succinctly expresses the two-fold manner of contact with God which the faithful achieve in the church: ut, et hic sacramentorum virtus et votorum obtineantur effectus, 755. The character of prayer as "sacrifice" 1 is also found in the use of this noun. The secret for the dedication of a church is a case in point: $u t$, dum haec vota praesentia reddimus, ad aeterna praemia... pervenire mereamur, 55 ; see also $563,1180$.

Once votum has the sense of "desire" in a broad sense of "that which is pleasant": Mysticis... repleti sumus votis et gaudiis, 718 .

\section{TERMS WHIGH HAVE REFERENGE TO THE INNER \\ EFFICACY OF THE SACRED ACTION}

In Chapter I, we have already met a number of words which indicate the effects of the Eucharistic action. Such, for example, are benedictio ${ }^{2}$, salvare, salvatio ${ }^{3}$, sanctificare, sanctificatio ${ }^{4}$, to mention but a few. We shall treat others when we consider the terminology of group languages in Chapter III. The object of this section is to investigate some of the more-or-less general terms, which have acquired a technical sense, or at least have taken on a special connotation, when they are used to convey the idea of the supernatural productiveness of the external rites.

\section{Terms designating divine activity}

EFFECTUS, effective sacramental action, answer to prayer.

We have here a word of comparatively late origin and one which had so broad and general a meaning that it could become a technical term in law, medicine, astrology, and philosophy $y^{5}$. Since Diezinger has devoted a monograph to this word in the liturgy ${ }^{6}$, we need only to point out some of the philological factors regarding its use in the ORATIONS.

The presence of effectus, for the most part in secrets and postcommunions, points at once to its meaning as the "sacramental effect", "the inner divine efficacy of the ritual action". It has, indeed, an active connotation in some instances where it is almost the equivalent of

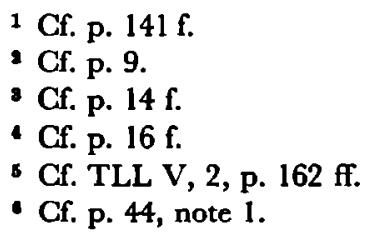


virtus $^{1}$. The following are cases in point: Munda nos... sacrificii praesentis effectu, 686, 677; ut, quae visibilibus mysteriis sumenda percepimus, invisibili consequamur effectu, 841; quod votis celebrat, comprehendat effectu, 848; ut, cujus exsequimur cultum... sentiamus effectum, 963, 1065; Repleti sumus... muneribus tuis: tribue... ut eorum et mundemur effectu, 975 ; ut effectibus nos eorum veraciter aptare digneris, 957 . Note how vividly the closing phrase of the prayer for the blessing of the font conveys the concept of effectus as a "working power": ut, quod nostrae humilitatis gerendum est ministerio, virtutis tuae impleatur effectu, $754^{2}$.

There are times when this noun is used for stylistic reasons. In some of these cases it retains the full import of its meaning, as, for example, in the postcommunion for Fer. IV Quat. Temp. Adv., where parallelism and rime are obviously sought: cujus laetamur gustu, renovemur effectu, 1026. But there are instances where its meaning is less sharply defined by reason of the fact that it is used with a genitive of definition or of identity, and these carry the meaning. Into this category fall such prayers as the secret for Fer. III p. Dom. III Quadr.: Per haec veniat... sacramenta nostrae redemptionis effectus, 812; Here redemptio and effectus are identical. Note also the following: ut illius salutaris capiamus effectum, cujus per haec mysteria pignus accepimus, 940 ; festivitas: salutaris auxilii nobis praestet effectum, 1032; ut cum frequentatione mysterii, crescat nostrae salutis effectus, 1090. optatae... indulgentiae praestet effectum, 574 . Effectus is sometimes identified with purely eschatological realities: effectum beatae perennitatis acquirat, 132; ita perenniter ejus gloriae salutaris potiamur effectu, 657; ad perpetuae ducant salvationis effectum, 924. By defining effectus as "right living", the postcommunion for 14 Oct.: et recte vivendi nobis operentur effectum, 948, constitutes an expression of the fact that the liturgy is the source of actual grace; see also 793.

The addition of the pronominal adjective tuus to redemptio and salvatio indicates that effectus is modified by a subjective genitive and thus it retains its full value in: ut tuae redemptionis effectum, et mysteriis capiamus, et moribus, 958; sic nobis effectum... tuae salvationis impendant, 1064; but now the content is static rather than dynamic. When it stands for the fulfillment of requests made in prayers, it means "outcome": $D a \ldots$ piae supplicationis effectum, 167; concede... piae petitionis effectum, 264; et votorum obtineatur effectus, 755 . Interestingly enough, too, it is employed once in a medical context: Da... nostris effectum jejuniis salutarem, 181.

1 Cf. p. 127 f.

Cf. Diezinger, op. cit., p. 72 f.

- Cr. DE Soos, op. cit., p. 59 ff., 93 f.; DiezInger, op. cit., p. 55. 
EFFICERE, to cause to exist in a certain way (i.e. to cause to have certain characteristics) ${ }^{1}$, to produce.

As applied to the sacred action, this verb is used often with a double accusative, much in the same manner in which Cicero used it when he said: fortuna... eos plerumque efficit caecos, quos complexa est ${ }^{2}$. The meaning of the verb is essentially the same, though transferred to a supernatural plane of course, when it is applied to the inner action of the Eucharistic rite as producing certain characteristics: Haec hostia... tua nos protectione dignos efficiat, 580 ; oblatio... dignos sacra participatione efficiat, 925 ; libatio... sui nos participes potenter efficiat, 996. Haec oblatio... cordis nostri maculas emundet: ut Sancti Spiritus digna efficiatur habitatio, 594; see also 1015. It forms part of a stylistic periphrasis which makes it possible to state in the second member of the prayer the same petition as is expressed in the first: Purificent nos... sacramenta quae sumpsimus: et... a cunctis efficiant vitiis absolutos, 921. When jejunia is its subject, it still has the same construction and meaning as it has in the foregoing examples. Note the following: quae (jejunia) et expiando nos tua gratia dignos efficiant, 11, 722; abstinendo, cunctis efficiamur hostibus fortiores, 174. This verb is attributed directly to God: Deus, qui fidelium mentes unius efficis voluntatis, 342; 1149, 367; and to His work through the ritual act: Deus, qui nos per hujus sacrificii veneranda commercia, unius summae divinitatis participes effecisti, 409.

In the postcommunion for St. Donatus: qui nos sacramentorum tuorum et efficis participes et ministros, 748, it is interesting to note how ministros is drawn into the same construction as participes, even though strictly speaking one is not "made" a minister of the sacred action in the same sense as one is "made" a particeps therein. Finally there is the secret for Fer. V p. Dom. I Pass.: ut (munera) et vitae nobis praesentis auxilium, et aeternitatis efficiant sacramentum, 487, which is the only case in which efficere is employed with a single accusative and means simply "to produce, to effect". It is only in this last instance that this verb has dynamic sense. For the rest it has simply the more usual Late Latin meaning of facere. Noteworthy, then, is the difference between the verb efficere and the noun effectus. This latter has nearly always the dynamic connotation. We have here, once again, an instance of the fact that nouns are more apt to become technical terms than verbs are.

OPERARI, to act as efficient cause of supernatural effects.

From the beginning, this verb had a very broad and general sense. Recent studies have been dedicated to an investigation of its

1 Cf. TLL V, 2, p. 164 ff.; Antibarbarus, I, p. 446 f.

2 Lael. 15, 54. 
origin and use ${ }^{1}$. Since operari underwent an extraordinary development in the Christian language, not only in the general moral sense of good and evil "works", but also in the special connotation of "the work of God" in the creation and redemption of the world", it is not surprising that we find this very pregnant term in the orations to impart the concept of God's effective approach to man in the cult. In the collect for Sabb. Sanct. p. Proph. II: dum quod uni populo, a persecutione Aegyptiaca liberando, dexterae tuae potentia contulisti, id in salutem gentium per aquam regenerationis operaris, 211, operari has reference to the action of God in Baptism as the spiritual fulfillment of the OT type. Divine activity is present in the Eucharistic action, as the following secrets reveal: Sanctificationem tuam nobis... his mysteriis operare placatus, 1044; quae (benedictio) et sanctificationem nobis clementer operetur, 1095; ut haec sacrosancta mysteria gratiae tuae operante virtute, 1127 ; operare: ut quod... mysterio gerimus, piis affectibus consequamur, 1128; see also 1161, 1131, 816 .

The fact that the production of internal, supernatural effects is attributed to the ritual actions themselves is evidence of the theandric character of the cult. Hence we have such significant prayers as: ut munera... et medelam nobis operentur, et gloriam, 514 ; hostia... salutare tuum in nobis mirabiliter operetur, 469 ; munera... exsolvimus: praesta... ut remedium nobis perpetuae salutis operentur, 895. Once the sacred action is represented as productive of proper moral living: et recte vivendi nobis operentur effectum, 948.

This verb does not occur in the oRAtions in the special Christian sense of "to perform works of mercy", nor in the more general moral sense; but operari in this connotation is not completely absent from liturgical language, for of the $\mathbf{3 7}$ times that this verb appears in the Veronense, six have the moral content.

opERATIO, effectiveness, action.

In the orations this Late Latin noun is, for the most part, restricted to the theological concept of the inner supernatural effectiveness of the ritual action. Its use with a subjective genitive (or with an adjective in place of a subjective genitive) illustrates this in the following: Mentes ... et corpora possideat... doni caelestis operatio, $677 ;$ Per hujus... operationem mysterii... vitia nostra purgentur, 813 ; Suscipe... sacrificium, ut, hujus opera-

1 G. G. KeEL, Laborare und operari. Verwendungs- und Bedeutungsgeschichte zweier Verben für "arbeiten" im Lateinischen und Gallo-Romanischen, Bern 1942, passim; JANSSEN, op. cit., p. $217 \mathrm{ff}$, and PÉtrE, op. cit., p. $261 \mathrm{ff}$., investigate especially the sense of this verb as "to perform works of mercy"; while BASTIAENSEN, op. cit., discusses it from a liturgical point of view.

${ }^{2}$ Cf. Rent Braun, op. cit., p. 382 ff., esp. p. 382, note 3 and p. 383. 
tione mundati, 1121 ; et operatione sua tibi placitos esse perficiant, 1151 . The sacramental character of the word is also pointed up by the fact of its usage in postcommunions: Augeatur in nobis... tuae virtutis operatio, 63; Tua nos... medicinalis operatio... expediat, 1146 . There is no direct mention of the external rite in the clause which contains operatio in the secret for Sabb. in Alb.: ut continua nostrae reparationis operatio, 124; but there can be little doubt that the noun here has the same sense as it has in the instances quoted above. For a discussion of the secret for Fer. VI p. Dom. II Quadr., see p. $93 \mathrm{f}$.

Operatio has the broader Christian sense of "a work of God"1, when it appears with the subjective genitive in the collect for Dom. XVII $p$. Pent.: Dirigat corda nostra... tuae miserationis operatio, 470 . It means human actions in: ut... oratio et operatio a te semper incipiat, 18.

PRODEsSE, to be of use, to benefit.

We have here another rather colorless word used in the ORATIONs to convey the notion of the inner working of the ritual action. It is predicated directly of the oblatio: haec nobis prosit oblatio, 54, 717; or of the reception of the Eucharist which is called medicina: ut... medicina sacramenti et corporibus nostris prosit, et mentibus, 973; see also 909, 324.

In addition to its absolute use, it is found with $a d$ and the accusative: ut, quod... celebramus, nobis prosit ad veniam, 516 ; ut, quod illis contulit gloriam, nobis prosit ad salutem, 1017; see also 1079, 756. Noteworthy is the fact that though the dative was the usual construction with prodesse, still the only one time that it is employed here is: ut, quod fragili celebramus officio... nobis prodesse sentiamus auxilio, 972; and in this prayer it is obviously called for by reason of the rime.

PROFICERE, to be conducive to well-being, to be of advantage, to advance in a good life.

In its transferred sense, this verb occurs rather frequently to express the inner sacramental action of the Eucharist. Though it is of itself abstract, it becomes alive when it appears in context. We have such phrases applied to the ritual action as: quas... devota mente celebrat, proficere sibi sentiat ad salutem ${ }^{2}, 616 ;$ Munera... deferimus... ut... nobis proficiant ad salutem, 701 ; oblationes... assume; ut... cunctis nobis proficiant ad salutem, 881 ; see also $383,689,831,897,901,978$; Perceptis... sacramentis... nobis proficiant ad medelam, 815, 814; ut paschalibus initiata mysteriis, ad aeternitatis nobis medelam ${ }^{3}$, te operante, proficiant, 1131 ; ut haec salutaria sacramenta

1 Cf. RenÉ Braun, op. cit., p. 383.

2 Cf. p. 55.

${ }^{8}$ Cf. p. 183 f. 
illis proficiant ad prosperitatem et pacem, 474; haec oblatio nobis proficiat prosperitatem et pacem, 1144; ad futura bona, 1154; ad indulgentiam, 603; ad placationis augmentum, 932; in auxilium, 1083. Although in post-Classical times there was an ever increasing tendency to use ad (less frequently in) with the accusative instead of the dative to express purpose ${ }^{1}$, still it seems that there is an added reason for the frequency of the former construction here. There is a definite note of movement, of increase, included in these phrases. Salus, medela, pax, are all concepts which are not static but which increase constantly until the full maturity is reached after death. Hence proficere takes on a concrete meaning; it imparts the notion of "bringing about a real increase", or of "effecting a definite result". The postcommunion for Fer. IV p. Dom. II Quadr. expresses this increase literally: Sumptis... sacramentis: ad redemptionis aeternae... proficiamus augmentum, 1087; but here the verb has its proper sense of "to grow, to progress". Such is its meaning in the collect for Fer. II infra Oct. Pasch. also: ut (sc. populus) ... ad vitam proficiat sempiternam, 448.

Proficere is also used in the special sense of "to advance in a good life" 2 . We find it in the clauses: ut... proficiamus et fidei consortio, et digno servitio, 748; superbe non sapere, sed tibi placita humilitate proficere, 155; and in the somewhat exaggerated word-play; da nobis eorum gloriam sempiternam et proficiendo celebrare, et celebrando proficere, 408; see also 872, 898, 729b. It means "to draw profit from" in the following: tantae fidei proficiamus exemplo, 190; ut Ecclesia tua aeternis proficiat institutis, 373; see also $297,412,959$. In the phrases: animabus... oratio proficiat, 52 ; da ei... verbo et exemplo, quibus praeest, proficere, 239 ; and quod Ecclesiae... corporalibus proficit spatiis, 321 , it stands for "to be of advantage to".

We have here one of those words which in the hieratic language of the liturgy are rather neutral ${ }^{3}$, and thus can easily be colored by the context in which they are used. Hence, at times its meaning is full and rich as when it is used to indicate the effects of the sacred rites; while at other times its content is shallow indeed.

viRTUs, supernatural power of God; courage, moral virtue.

This ancient Latin word, which, according to A.N. van Omme, had originally in the colloquial language the dynamic connotation of "miraculous or magic power", developed secondarily the notional meaning of "prowess, bravery, virtue"4. In Christian Latin it became the regular

1 Cf. Kühner-Stegmann, op. cit., I, p. 345 f.

2 Cf. Blaise, Dictionnaire, p. 669.

3 Cf. Mohrmann, Etudes, II, p. 107.

- "Virtus", een semantiese studie, Utrecht 1946, p. 18 ff. and $110 \mathrm{ff}$. 


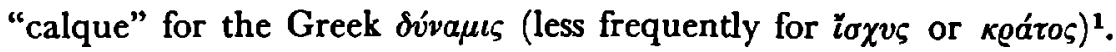
As such, virtus stands for the supernatural force of God which is productive of wonderful effects.

For the sake of historical continuity, we shall begin with the general Christian sense of this noun, and then we shall treat its special liturgical connotation. In the blessing of the bride after the Pater Noster - a prayer, which in many respects diverges widely from the compact style and the artificial vocabulary of the other ORATIONs - we find the only example where this noun is applied to the power of God exhibited in creation: qui potestate virtutis tuae de nihilo cuncta fecisti, 434 . It has reference to the power symbolized by the right hand of God: eorum contumaciam dexterae tuae virtute prosterne, 628 . We find it characterized as magna virtus, 545 , and superna virtus, 561 ; and by its force we hope to be protected: tuae semper virtutis mereatur protectione defendi, 184. It forms a deep contrast to human physical weakness in the postcommunion for the sick: auxilii tui super infirmos famulos tuos ostende virtutem, 234; and more effectively still, to moral weakness in the prayer over the people for Fer. VI p. Dom. IV Quadr.: qui infirmitatis nostrae conscii, de tua virtute confidimus, 175. When we find the phrase: Adsit nobis... virtus Spiritus Sancti, 44, in a collect, we may consider this a mere literary borrowing from epiclesis terminology, serving as a stylistic device for a prayer during the Octave of Pentecost.

Since it is so intimately related to God Himself, virtus is an apt term to express the idea that the inner effectiveness of the cultic act is divine. This we find literally expressed in the collect of the Mass for the consecration of a bishop: quod humilitatis nostrae gerendum est ministerio, tuae virtutis impleatur effectu, 39 and in the identical formula in the prayer for the blessing of the font, $754^{2}$. To make it supernaturally effective, divine power is called down upon the altar in the postcommunion for the Mass of its dedication: altare hoc... caelestis virtutis benedictione sanctifica, 755. This prayer merits an extra remark, for virtus occurs twice in it. The clause just quoted is a kind of epiclesis formula ${ }^{3}$ in which the

1 Cf. Rent Braun, op. cit., p. 106 ff., esp. 108.

I St. Leo, when speaking of the inner validity of Baptism, uses this same term: Formam tantum baptismi sine sanctificationis virtute sumpserunt, Epist. 159, 7. Cf. also Ysebaert, op. cit., p. $327 \mathrm{f}$, for a discussion of distinctions made by Christian authors between the outer ritual action and the inner effect of Baptism.

s The noun virtus occurs also in the solemn epiclesis formula in the blessing of the font of the Roman usage: Descendat in hanc plenitudinem fontis, virtus Spiritus Sancti. One Visigothic epiclesis reads: virtus quoque tua de caelis descendens; Liber Mozarabicus, Ferotin, 387. Eizenhörer, op. cit., p. 74, cites also the Egyptian liturgy of Serapion 
power of God is directly invoked: so that: et hic sacramentorum virtus, et votorum obtineatur effectus, 755 . In this latter clause virtus is the inner efficacy of the sacred action. The difference consists in the point of view from which it is considered rather than in the meaning, for in both instances there is question of a real divine efficacy.

Virtus in this sacramental sense is found in other oRATIons also in regard to the central cultic act, the Eucharist. It may be that it is ascribed directly to God as in the postcommunion for Dom. II p. Epiph.: Augeatur in nobis... tuae virtutis operatio, 63; or to His grace as in the secret for Dom. VII p. Pent.: ut haec sacrosancta mysteria, gratiae tuae operante virtute... sanctificent, 1127 . Again it may be attributed directly to the sacred action itself, as the parallelism and juxtaposition of the secret for Dom. II p. Pasch. has it: quod agit mysterio, virtute perficiat, 81 ; and as is also found in the less stylized phrases: Haec sacra nos... potenti virtute mundatos... faciant puriores, 595; per hujus virtutem sacramenti, 877, 1133; caelestis mensae virtute satiatis, 1140 ; hujus virtute mysterii... liberemur, $1158-4$.

Even when virtus is used for "courage" or for "virtue", the meaning which it had in profane Latin, there is clear evidence of the renewal of its content by reason of its contact with Christian ideology. Thus, it stands for the more-than-human courage of the martyrs in: qui beatum Hermetem Martyrem tuum virtute constantiae in passione roborasti, 292, and, virtutem quoque passionis imitemur, 400 . The collect of the Mass, Me expetaverunt reads: quae tibi grata semper exstitit, et merito castitatis, et tuae professione virtutis, 647; where virtutis may be construed as an objective genitive representing the Divine power which supported the virgin in martyrdom. The older form of this prayer, which is found in the Gel. Vetus for the feast of St. Agatha, expresses this concept even more clearly: quae tibi grata extitit virtute[m] martirii et merito castitatis $\mathbf{1}$.

Because it is used in the plural, we may consider the meaning of virtus to be closer to what we mean by "virtue" in a moral sense in the following: quae et fidei nostrae praebeat incrementa virtutum, 570; eorum etiam virtutes imitemur, 870. This is surely its meaning, even though it be singular, in: concede nobis verae humilitatis virtutem, 450 . Even when this noun refers to "human strength or capability" it is related to the supernatural order: Deus, qui conspicis omni nos virtute destitui: interius exteriusque custodi, 313; ut te toto virtute diligant, 312.

where $\delta v^{\prime}$ a $\mu 5$ occurs in the epiclesis. All these examples reveal clearly the dynamic content in the word virtus.

1 Mohlberg, 832. 


\section{Some very general terms}

CAPERE, to receive, to enjoy the possession of.

Occurring almost exclusively in postcommunions capere may be interpreted in the sense of de effectu capiendi ${ }^{1}$. Its frequent usage here may have been influenced by the fact that capere was also used specifically of "to take food". Such a phrase as: Quod ore sumpsimus (contingimus)... pura mente capiamus, 952, 878, would strengthen the supposition that capere here indicates in the supernatural order what sumere conveys of the external rite. But such a relation is not always present. That it is a technical expression for "to receive, to enjoy the possession of" that which is externally performed in the Eucharist, is evident from the following:

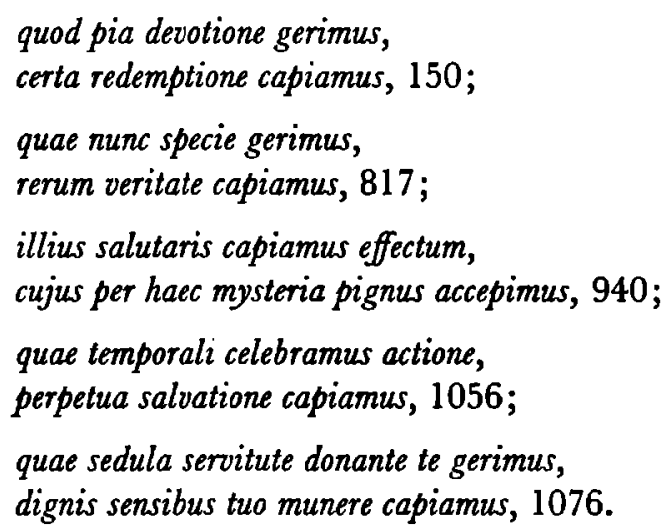

Thus, capere has a definite sacramental connotation. Its meaning is also essentially the same in the following, even though there be no parallelism to point it up so clearly: Ut divinis vegetati sacramentis, ad eorum promissa capienda, tuo munere praeparemur, 63, Tantis... repleti muneribus: praesta... ut et salutaria dona capiamus, 1136; see also 920, 958, 70, 177. As applied to the departed, capere means "to enjoy the possession of" 2 indulgentiam pariter et requiem capiant sempiternam, 845; see also 909 . Finally, there is one instance in which this verb means "to grasp with the mind": ut, terrenis affectibus mitigatis, facilius caelestia capiamus, 873.

CONSEQUI, to attain a supernatural effect or gift.

A very general word for "to acquire, to obtain", this verb came in Early Christian Latin to have the specific sense of "to receive grace", especially the grace of Baptism ${ }^{3}$. Whether it was under the influence

1 Cf. TLL III, p. $383 \mathrm{ff}$.

2 Cf. BlaIse, Dictionnaire, p. 130.

af. TLL IV, p. 404 ff., esp. p. 408, 1. 69 ff. Among Early Christian inscriptions 
of this special meaning, or simply because of its more-or-less vaguely defined character, that consequi came to be used to convey the act of receiving the inner sacramental effect of the sacred action, is difficult to determine with certainty. There is, furthermore, the added possibility of Biblical influence, for this term appears some 40 times in the NT with salus or misericordia 1 .

Be that as it may, note how consequi expresses in human language an "act of acquiring" which is itself above human susceptibility. In most of these cases a rhetorical parallelism and juxtaposition enhance the beauty of the concept: quae temporaliter agimus, spiritualiter consequamur, 718; ut, quae visibilibus mysteriis sumenda percepimus, invisibili consequamur effectu, 841 ; quod tempore nostrae mortalitatis exsequimur, immortalitatis munere consequamur, 964 ; quod temporaliter gerimus, aeternis gaudiis consequamur, 1075; see also 606, 802, 862, 1128. In these cases there is no question of a mere natural "receiving or attaining". This fact is conveyed by the modifiers spiritualiter, invisibili effectu, immortalitatis munere, aeternis gaudiis. In the postcommunion for Dom. II p. Pasch., we have the phrase: vivificationis gratiam consequentes, 840. It is noteworthy, too, how vividly the theandric nature of the Eucharistic rite is brought out in the above citations, for quod or quae appears as the object of one of the verbs denoting the external action and of consequi as well. Then we have instances when the reception of supernatural effects is petitioned as the result of the participation in the Eucharist: $u t$ per haec sancta, quae sumpsimus... veniam consequamur, et pacem, 861, et veniam... consequamur et gratiam, 1020; see also 840, 969, 1126. Twice this verb is applied to the actual reception of the sacrament, with no distinction between the external rite and the internal effect: Immortalitatis alimoniam consecuti, 638 ; cujus perpetuae misericordiae consecuta est sacramentum, 654. Though we translate sacramentum as "pledge" in the latter instance, still it refers to the Eucharist since it is the pledge of eternal glory.

The reception of supernatural gifts is sometimes the object of a direct petition made to God. Here again the "reception" is above the power of nature, for the objects are supernatural: promissiones tuas, quae omne desiderium superant, consequamur, 323; so the collect for Dom. V p. Pent. literally expresses it. Other objects are: beneficia, 380; resurrectionis gratiam, 438; perfectam libertatem, 448; aeternitatis gloriam, 212; indulgentiam, 225, 567; remedia, 1157, quod fideliter petimus, 461, 903; quae digne

this word is found with this connotation: quae sana mente salutifero die Paschae gloriosi fontis gratiam consecuta est, DrEHL, op. cit., 1523; see also 1524-1528.

1 Cf. Dutrupon, op. cit., p. 884 f. 
postulant, 880. The last two citations could include natural objects, but fideliter relates the former, at least, to the supernatural order.

PARTICEPS, a sharer.

This noun is used both of God in so far as He has assumed human nature and of man in so far as he is raised to the supernatural level ${ }^{1}$. St. Augustine expresses this very aptly: Neque enim efficeremur participes divinitatis eius, nisi ipse mortalitatis nostrae particeps feret ${ }^{2}$. In the ORATIONs it refers usually to the state of being a sharer in the Eucharistic action: quos tanti mysterii tribuis esse participes, 2 ; ut mysterium cujus nos participes esse voluisti, 92 ; see also $686,748,996$. Once it stands for the state of the faithful departed after they have been freed from sin: ut eas et a peccatis omnibus exuas, et tuae redemptionis facias esse participes, 52.

PARTICIPATIO, a sharing, a having in common, (here, specifically of the effects of the Eucharist ${ }^{3}$ ).

This Late Latin noun occurs in the orations in the sense which it has in the Vulgate, 1 Cor. 10, 18: Calix benedictionis... nonne communicatio sanguinis Christi est? et panis, quem frangimus, nonne participatio corporis Domini est? Here both participatio and communicatios are used to translate

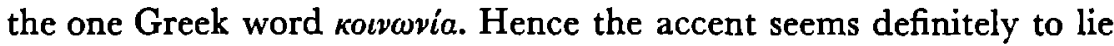
more heavily upon the idea of "union with" than upon that of "sharing in"; however, the two concepts necessarily overlap each other. Thus there is achieved in the Eucharist union with God. The sharing in it is called a divine participation: quos divina tribuis participatione gaudere, 947. It is the source of life: Divini muneris... satiati, quaesumus... ut hujus semper participatione vivamus, 477; Vivificet nos... hujus participatio sancta mysterii, 1178. By it we are constantly saved: et eorum (altaria) perpetua participatione salvari, 836; Sacramenti tui... participatio salutaris, et purificationem nobis tribuat, et medelam, 997. It is also the contact in which God teaches us true values: ut hujus participatione mysterii, doceas nos terrena despicere et amare caelestia, 970.

The postcommunion for Dom. XVIII p. Pent.: ut dignos nos ejus participatione perficias, 576; and the secret for Fer. III infra Oct. Pent.: Purificet

1 Cf. Herz, op. cit., p. 202 f., 298.

Ennar. in ps. 118, S 16, 16.

3 Cf. Herz, op. cit., p. 202 f.; Blaise, Dictionnaite, p. 596; Mueller, op. cil., p. 9.

- It is noteworthy that communicatio does not occur in the orations. Communio appears only 4 times; twice it is used absolutely, thus as a technical term for the reception of the Eucharist, 587, 588; twice it has a more active sense of a "sharing in": Sactamentorum... communio sumpta nos salvet, 1000 ; communio sactamenti... purificationem conferat, 1159. The verb communicare occurs once in a phrase which is an allusion to the text of 1 Cor. 10, 18: cujus corpori communicamus, et sanguini, 942. 
nos... oblatio : et dignos sacra participatione efficiat, 925 , seem to lend weight to the interpretation of participatio as "union with" rather than as "reception of". We pray that God may make us worthy of the participatio, not worthy "to participate". Number 576 is a postcommunion. We would hardly ask to receive it worthily after we had partaken of the Sacrament. Again, it seems that in 925 there is question of the ritual action's making us worthy of the participatio in much the same way that we pray that it make us worthy of gratia, 11; of protectio, 580 ; or of redemptio, 955.

Not always, however is this noun so vital and vivid. It is somewhat of a cliché in such prayers as: Caelestis participatio sacramenti... animabus... requiem et lucem obtineat perpetuam, 106; ut, quorum memoriam sacramenti participatione recolimus, 872; see also 916, 963. In these it is closer to what we term "reception of the Eucharist".

PERDUCERE, to lead toward an objective.

This is another expressive term which conveys the notion of "movement toward a destination". The supernatural life is a reality which is constantly "moving" and the ritual action "leads" towards its full realization. Thus we pray in the postcommunion for Fer. VI p. Dom. III Quadr.: Perceptio sacramenti... ad caelestia regna perducat, 630 . This need not indicate only that the Eucharist is conducive to eschatological bliss in the strict sense of that term. We are constantly advancing toward a fuller realization of the caelestia regna, the first germ of which we have received at Baptism. Such pregnant phrases as the following impart this notion vividly: Per haec veniat... sacramenta nostrae redemptionis effectus: qui nos et ad salutaria dona perducat, 812; haec sacrosancta mysteria... ad gaudia sempiterna perducant, 1127; ad caelestia dona perducat, 1044. The same effect is requested of the ritual fast of Lent: jejunia... ad sempiterna promissa perducant, 11 ; jejunia... ad remedia perducant aeterna, 722 . Note also how in the collect for Epiphany usque emphasizes the notion of movement even more strongly: concede... ut... usque ad contemplandam speciem tuae celsitudinis perducamur, 351 . That the moral life is regarded as a "way" is a universally known fact". This finds expression in the postcommunion for Dom. VII p. Pent.: Tua nos... medicinalis operatio... ad ea quae sunt recta, perducat, 1146. Once perducere is said of the soul of a departed one: jubeas eam a sanctis Angelis suscipi, et ad patriam paradisi perduci, 208.

PERVENIRE, to arrive at, to reach a goal.

This verb is used frequently to indicate the attainment of eternal 1 Cf. p. 196. 
happines. This is probably because it is a vivid word and contains the concept of movement toward a goal, as well. As the effect of the Eucharist we find it in the following: Fac nos... accepto pignore salutis aeternae, sic tendere... ut ad eam pervenire possimus, 551 ; oblatio salutaris famulum... tueatur... quatenus... ad aeternam perveniat hereditatem, 578; Suscipe... munera ...et concede... ut... ad vitam perveniamus aeternam. 1110; see also 641, 608, 906.

More frequently, pervenire occurs in collects, where the eschatological good is officially petitioned in such phrases as: ad aeterna praemia... pervenire, 55 ; ad vitam... perveniat sempiternam, 239 ; ad aeterna gaudia pervenire, 385,411 ; ad caelestia regna perveniat, 434 ; ad perpetuae beatitudinis consortium pervenire, 465 ; ad dona perveniat sempiterna, 520 . Twice it occurs in a context where we would rather expect to find consequi ${ }^{1}: u t, t i b i$ servientes, ad tuam jugiter misericordiam pervenire mereantur, 156; dignis conversationibus ad ejus mereamur peroenire consortium, 164. It has a figurative sense of "to come to" in the collect for the Vigil of the Birth of St. John the Baptist: ad eum quem praedixit, secura perveniat, 856; and of "to arrive at" in that of Fer. VI p. Dom II Quadr.. sinceribus mentibus ad sancta ventura facias pervenire, 193.

1 Cf. p. 130 f. 


\section{TERMS FROM GROUP LANGUAGES}

\section{A. PAgAN ROMAN RELIGIOUS TERMS}

In the earliest period of Christianity in the West, there was a general tendency to avoid terms which were strongly reminiscent of pagan religion. The Christians felt themselves to be a people apart, who had broken completely with everything that was related to pagan worship. And thus, the scarcity of technical pagan religious terms in Christian writings of the first centuries is due to two factors. The first is that the Christian communities were closely consolidated groups who tried deliberately to develop a typically Christian religious vocabulary. Hence their language bore the marks of a linguistic variant within the framework of the general language. The second factor is perhaps even more important. As we have already pointed out, the Latin-speaking Christians displayed a strong aversion - sometimes to the point of prudishness - for words which were proper to pagan cult ${ }^{1}$. It is a linguistic fact that technical terms do not immediately take on a new technical meaning; and the Christian communities could not risk using words which might relay false impressions. Hence these terms did not find their way into colloquial Christian speech. However, after the freedom of the Church, when paganism no longer presented a threat to Christianity, old Roman religious terms could be used without fear. Furthermore, at this time they possessed a certain stylistic coloring both because they were archaic and because to the Christians they had an unusual ring. As such they were excellent material for the solemn prayers of the Church.

ACCEPTUs; see Terms which express the action of God in regard to the gifts, p. 87. ANNUERE, to assent to ${ }^{2}$.

This word in pagan religious terminology described the gods' manner of answering prayers: "ut reges concedunt nutu suo aliquid per famulos perfici", as G. Appel expresses it $^{3}$. In the ORATrons it is always

1 Cf. Mohrmann, Liturgical Latin, p. 44; Etudes, I', p. 99 f., 120 f.

Cf. TLL I, p. 789; Antibarbarus, I, p. 156.

Op. cit., p. 183. 
in a place of emphasis; namely, at the beginning of the prayers; and it is always followed by an ut-final clause: Annue... ut hostias placationis et laudis, sincero tibi deferamus obsequio, 53. Once the phrase is expanded to read: Annue... precibus nostris, ut..., 55; see also 54 and 56 .

CELebrare, to solemnize by a religious festival, to perform a public ritual act.

For such festivities as were public and attended by many participants, as for example the days of the public games, the term celebrate was used in profane Latin'. In the orations this term is applied usually to the annual liturgical "celebration" of the feasts of the saints: cujus solemnia celebramus, 930, 1060, 1061, 1075-2, 1180. It is also used with natalitia, 165, 847; festivitatem ${ }^{2}, 225$; festa, 529; nativitatem, 1143. All of these are in line with the strict classical meaning of the verb. The clause: cujus anniversarium dedicationis diem celebramus, 55, on the anniversary of the dedication of a church, and: qui sanctae Dei Genetricis requiem celebramus, 115, on the vigil of the Assumption also fit under this head. In the last-mentioned example, requiem is an elipsis for diem requiei and the whole clause refers to the festival celebration on the anniversary of Mary's dormitio ${ }^{3}$.

The central religious act on such festive days in the Christian church was the Eucharistic Sacrifice, as the postcommunion of Ss. Primus and Felician has it: caelestibus mysteriis celebrata solemnitas, 949 . So, too, the Lenten season was officially opened with the Eucharistic celebration: Fac nos... his muneribus offerendis convenienter aptari: quibus ipsius venerabilis sacramenti celebramus exordium, 554. It was but one step further, then, to apply the verb concretely to the performance of the rite itself: Preces et hostias beati Petri Apostoli commendet oratio: ut, quod pro illius gloria celebramus nobis prosit ad veniam, 516. The relative pronoun (quod for id quod) stands for the ritual action. Another good illustration is: Hostias... tuae plebis intende: et quas in honore Sanctorum tuorum devota mente celebrat, proficere sibi sentiat ad salutem, 616 . Sometimes there is preserved the idea that the sacred rite is performed to commemorate a saint's feast, as in 516 and 616 quoted above, or that it is performed to commemorate the sacrificial death of Christ Himself: quoties hujus hostiae

1 E.g., dies festos ludorum celebrare, Cic., Arch. 6, 13; Pis. 22, 51 ; cf. TLL III, p. 742 ff.; Antibarbarus, I, p. 244; DE Soos, op. cit., p. 29 ff.; Bastiaensen, op. cit., p. 60.

- Cf. p. 110 for discussion of the unusual character of festivitas as object of celebrare.

3 Dormitio is the Latin form of kol $\mu \eta \sigma \iota$, the common term used for the death and glorification of Mary in Greek. This feast was introduced into the West from the East where it was celebrated very early. 
commemoratio celebratur, $120^{1}$. At other times the accent is more heavily laid upon the ritual content. This is effected by the addition of officio in: Praesta... ut quae solemni celebramus officio, purificatae mentis intelligentia consequamur, 862; quod debitae servitutis celebramus officio, 1022; or by the addition of actione ${ }^{2}$ : ut quae temporali celebramus actione, perpetua salvatione capiamus, 1056. Finally, this ritual element may simply be very evident from the context: Suscipe... preces populi tui cum oblationibus hostiarum: et tua mysteria celebrantes, $a b$ omnibus nos defende periculis, 1130 . The verbal noun celebratio, too, has a strong ritual content: Sumptis redemptionis nostrae muneribus: praesta... eorum nobis celebratione... subsidium, 1091. Note that the antecedent of eorum is muneribus, which includes participation in the Eucharist because it stands for the ritual action in its entirety. From these examples and especially from the phrase: ad sacrificium celebrandum, 581, it is not difficult to conclude whence the term "to celebrate Holy Mass" originated ${ }^{3}$.

There remains just a word to be said about two other usages of this verb. The first has reference to the collect of Sabb. p. Cineres: concede: ut hoc solemne jejunium... devoto servitio celebremus, 28. That the official fast of Lent has a ritual character is well-known. It is a religious act accomplished by the whole assembly of Christians, and hence has a certain breadth and dignity which calls for the use of the verb celebrare ${ }^{4}$. Secondly, there are a few instances where celebrare can be interpreted in the strict classical meaning of "to honor": da nobis eorum gloriam et proficiendo celebrare, et celebrando proficere, 408 . In this fine wordplay, the first celebrare means "to honor" and the second means "to perform sacred rites". "That we may honor" seems to be its translation also in: Gloriam... sanctorum... venerantes: quaesumus; ut eam, sacris mysteriis expiati, dignius celebremus, 571 .

COLERE, to venerate ${ }^{5}$, to celebrate a public feast in honor of a saint.

This was a common word for the act of worshipping the gods of pagan Rome, but it was rarely used by Christians to mean "render cult to the true God"'. In the orations it means "to celebrate a feast in honor of a saint". In fact, it is used only on feasts of saints; never does it refer (in the orations) to other annual celebrations, as for example that of Lent or Easter. The word includes all that goes to

1 Cf. p. 76.

2 Cf. p. $91 \mathrm{ff}$.

Cf. Rheinfelder, Kullsprache, p. $92 \mathrm{ff}$.

- Cf. DE Soos, op. cit., p. 34.

- Cf. TLL III, p. $1670 \mathrm{ff}$.

- Cf. Blasse, Dictionnaire, p. 169. 
make up the official performance of such annual feasts. The liturgy's fondness for fixed expressions which have a familiar and solemn ring can be seen here. In fact natalitia colimus occurs seven times: 190, 376, $400,403,459,863,864$, and solemnia colimus, four times: 189, 191, 787, 870. In the phrase: Da nobis... imitari quod colimus, 1651, colere means "to honor"; but the notion of a public liturgical celebration is surely included. And colimus may have been used alone here (i.e. not in the fixed phrase) for the sake of variety, since the other standard term for "to celebrate a feast", namely, natalitia celebramus, occurs also in this prayer.

DEDICARE, to set aside for the service of God.

This verb was used in profane Latin especially for the act of dedicating altars or buildings to the gods ${ }^{2}$. It is found frequently in inscriptions on pagan altars and buildings and on Christian buildings as well $^{3}$. In the orations, too, it is used exclusively in reference to the "dedication" of a church: loco quem nomini tuo indigni dedicavimus, 941; or of an altar: altare hoc nomini tuo dedicatum, 755. The noun dedicatio is also employed in this sense: cujus anniversarium dedicationis diem celebramus, 55.

DICARE, to consecrate, to set aside for God in a ritual performance.

A very technical term from ancient Roman prayer, this verb is used in the ORATIONS almost exclusively in the adjectival form of the perfect participle. The gifts offered are called munera..., hostias..., or sacrificia dicata. The meaning seems at first sight to be simply "offered to God". We ask God to receive the gifts which we offer: Hostias nostras... tibi dicatas assume, 617; or to sanctify them: Munera tibi, Domine, dicata sanctifica, 705. God has commanded that the material creatures which He has called into existence for man's support be also, in part, set aside as gifts dedicated to His honor: Tuo quoque nomini munera jussisti dicanda constitue, 487. Again, we honor the saints by means of gifts offered to God: quem (St. Donatus) ad laudem nominis tui dicatis muneribus honoramus, 846.

There is obviously a ritual connotation in muneribus dicatis just quoted where dicatis contains the notion of "being ritually holy", "set apart for

1 Cr. De Soos, op. cit., p. 93 f. The concept of the liturgical celebration's being an example for proper Christian moral living, as well as the source of strength for such living is oft-repeated in the orations; e.g. 213, 409, 869, 958, 1103.

Cf. APPEL, op. cit., p. 11 ; Antibarbarus, I, p. 364.

Cr. TLL V, p. 259, line 29 f.; Dieht, op. cit., 95, 695, 1308 A, 1792.

- Cf. TLL V, p. 953; CIL III, 1933. 
God". The munera ${ }^{1}$ are ritually holy, that is to say they become a part of the sacred action as soon as they are offered ${ }^{2}$. Oblatio nos... tuo nomini dicanda ${ }^{3}, 727$, (secret, Dom. II post. Pent.) is another illustration of the fact that dicanda indicates a real condition of being set apart for God, which condition is brought about in and through the ritual action regarded as a unity. In the secret of Dom. X p. Pent.: Tibi... sacrificia dicata reddantur: quae sic ad honorem nominis tui deferenda tribuisti, ut eadem remedia fieri nostra praestares, 1137, sacrificia dicata must be considered pleonastic: for dicata contains the same idea as sacrificia. Since sacrificium reddere Deo is a usual way of saying: "to offer sacrifice to God", it would be correct to translate the first clause not: "May our gifts be rendered holy by Thee"; but rather by some turn of speech as: "May these sacred (i.e. ritually set apart) gifts be offered to Thee". This connotation of dicatus gives to the phrase plebs tibi dicata, 319,898, its full import of "the people of God assembled before His face for cuLTIC purposes".

IMMOLARE, to offer sacrifice.

From its earliest proper technical sense of "to sprinkle a victim with salted meal and slaughter it" 5 , this verb came to be applied to the act of offering in general. There seem to be two factors which have influenced the use of this verb in the orations. On the one hand, there is the strictly classical feeling of "to immolate by slaughtering". This is manifested by the fact that in nine of the thirteen instances of its use it occurs with the noun hostia. We quote but one or two examples: Hostias tibi... deferimus immolandas, 621 ; Devotionis nostrae tibi... hostia jugiter immoletur, 469; Majestatem tuam nobis... haec hostia reddat immolanda placatam, 671. The second element which seems to have played a role in the choice of this verb is the fact that Ps. 115, 7 was so frequently used in the liturgy of the Mass in Latin.

The nomen actionis, immolatio, which means "offering" rather than "destruction", occurs but once: Suscipe... sacrificium, cujus te voluisti dignanter immolatione placari, 1121.

1 Cr. p. 164.

3 Cf. Alan Clark, The Function of the Offertory Rite in the Mass. A Study in Hislory, EL 64, 1950, p. 309 ff., esp. p. 415 ff.

- Dicanda may at first sight seem somewhat odd here, especially in view of the fact that this prayer appears two other times in the Gel. Vetus (MoHLaErg, 563 and 1121) in the identical form, but with dicata instead of dicanda. See the comments on the use of the gerund and gerundive p. $145 \mathrm{f}$.

- Cf. Ps. 49, 14; Ps. 21, 26.

sLL VII, p. 488 ff.; G. Wissowa, Religion und Kultus der Römer, München 1912, p. 417. 
LIBAMEN : a drink offering, sacrificial nourishment ${ }^{1}$.

This noun, drawn from the technical Roman religious terminology, where it means "drink offering" has found its way but once into the ORATIONs. Surely its proximity to sanguinis has occasioned its use in: Corporis sacri, et pretiosi sanguinis repleti libamine, 150. It is here simply a solemn term for "sacrificial nourishment". The verb, libare, too, has the secondary meaning of "taste" rather than "to pour out a libation", as can be determined from its use in the postcommunion: Divina libantes mysteria, quaesumus... ut haec salutaria sacramenta illis proficiant ad prosperitatem et pacem, 474; and Praesta... ut terrenis affectibus expiati, ad superni plenitudinem sacramenti, cujus libavimus sancta, tendamus, 849. Finally there is the noun libatio, which once retains something of its connotation: "the act of pouring out a sacrifice", when the verb infundat accompanies it: Sacramenti tui... divina libatio, penetralia nostri cordis infundat, 996 . But in: Tui nos... sacramenti libatio sancta restauret, 1160, it means simply "spiritual food".

PONTTFEX, bishop 2 .

This native Latin word, taken from Roman cultic language, is used in the orations to mean "bishop": 75, 225-2, 290, 540, 757, 886, 938$2,1031,1172$. Actually it is used already in the Latin translation of the Letter of St. Clement of Rome to the Corinthians, where o a oxtegev́s is used of Christ ${ }^{3}$. The expression summus pontifex is used of Christ in the preface for the anniversary of a bishop's consecration in the Veronensed, but the term as a designation for the Pope is of later origin and does not fall within the scope of this work.

\section{PRECES, prayer.}

A favorite word in ancient Roman prayer forms, this noun was for the most part avoided by most early Christian authors, in favor of the direct Christianism, oratio ${ }^{5}$. Then in the fifth century, because of its unusual character, it had a solemn ring which made it quite suitable for the lofty sacral style of the ORATIONs ${ }^{\mathfrak{\theta}}$. Hence in these prayers it

1 Cf. Forcellini-de Vit, III, p. 752; Botte-Mohrmann, op. cit., p. 115.

2 Cf. JANSSEN, op. cit., p. 92.

s 1 Clem. 36, 1.

- Mohlberg, 986.

b C. p. $117 \mathrm{f}$.

- "Oratio war das typisch christliche Wort für Gebet, weil man anfänglich preces (und precari) mied, da es heidnisch-sakral belastet war. Aber nach jahrhundertelangem Gebrauch war im fünften Jahrhundert oratio zu einem gemeinsprachlichen, banalen Wort herabgesunken, und die feierliche liturgische Sprache Roms nahm das einst gemiedene, jetzt als altertümlich und sakral empfundene preces auf". MohrmanN, Etudes, II, p. 26. Cf. also p. 127 f. 
is quite prolific; and one may distinguish three nuances in its use. In the first place there is its very general sense of prayer as such - usually prayer of petition. In this way it occurs very often in set forms as: exaudi preces, $392,528,530,531,538,540,541,778$; or preces... exaudi, 883, 884, 886, 887; respice ad preces, $414,753,757$. Sometimes such an affected phrase as: Praesta... precibus nostris cum exsultatione proventum, 834, occurs. Always, though, there is the one objective, namely that God may grant what is asked for. It is interesting to note that this noun is also employed in expressions with a Biblical flavor as: Ascendant ad te... preces nostrae, 59; Pateant aures misericordiae tuae... precibus supplicantium, 807; Inclina... aurem tuam ad preces nostras, 644.

In the second place, the word preces is used synonymously to intercessio for the mediatory power of the saints on behalf of the church on earth. We shall quote but two of the eleven examples of this because they are very much alike: ut, qui nostrae justitiae fiduciam non habemus, ejus, qui tibi placuit, precibus adjuvemur, 31 ; ut, in oujus haec commemoratione percepimus, ejus muniamur et precibus, 961 . The supplication made by the church militant for the church suffering is also sometimes expressed by preces: Suscipe... preces nostras pro anima famuli tui, $\mathcal{N}$.: ut, si quae ei maculae de terrenis contagiis adhaeserunt, remissionis tuae misericordia deleantur, 1117.

Finally, the word is used with a sacrificial connotation. Tertullian says that prayer is the real sacrifice of the Christian'. Among the early names for the Canon Missae was also prex. This laid stress on the fact that the Eucharistic Prayer was the prayer par excellence ${ }^{2}$. The word preces (it never occurs in the singular in the orATIONs) in secrets - orationes super oblata - has also something of a sacrificial character. Lietzmann says: "Es gelten als das Gott dargebrachte Opfer erstens die Gebete, zweitens Brot und Wein, die von der Gemeinde oder einzelnen Mitgliedern auf dem Altar niedergelegt werden, drittens die heilige Handlung am Altar selbst als Analogon des Todesopfers Christi"." These three ideas are often joined together. This is what we find often in regard to the word preces. It is joined with one or other word for "gifts" or for "ritual action". Thus we find it with hostia, as: suscipe preces et hostias famulorum tuorum, 219; dignare preces et hostias dicatae tibi plebis

1 Haec (oratio) est enim hostia spiritalis quae pristina sacrificia delevit... Nos sumus veri adoratores et veri sacerdotes qui spiritu orantes spiritu sacrificamus orationem hostiam Dei propriam et acceptabilem. De orat. 28, 1 and 3.

2 Cf. Jungmann, Missarum Sollemnia ${ }^{5}$, II, p. 128. It is interesting to note that St. Cyprian, De dom. orat., 31 , p. 289, employs the term oratio in this connection; while St. Gregory the Great, Epist. 9, 10, and others use prex.

s Lietzmann, Messe und Herrenmahl, p. 82. 
suscipere, 318 (see also 516, 819); with munera: Muneribus nostris... precibusque susceptis, 711 ; Suscipe... preces et munera, 1116; or with oblatio: Preces... tuorum respice, oblationesque fidelium, 882; oblationibus, precibusque susceptis, 908.

All of these are, furthermore, illustrations of a phenomenon which was frequent also in ancient Roman prayer, namely, the use of pairs of more-or-less synonymous words. Sometimes these are coordinated by $e t$, sometimes by -que. Other times the two words are joined together in the relation of subordination as in: Suscipe... preces cum oblationibus hostiarum, 1106, 1130, 1131. The use of such pairs of words adds a certain solemnity to the ritual style of the prayers ${ }^{1}$. But the phenomenon has an even deeper significance. These pairs constitute a kind of secondary lexicological unity; together they express one idea which includes more than is contained in the mere combination of the two words. E. Norden expresses it thus: "Die Paare sind entweder gegensätzlich oder komplimentär; in beiden Fällen unterstehen sie einer höheren Begriffseinheit"2. We may, then, consider that these wordgroups - preces joined to some word indicating sacrifice - stand for solemn prayer which is sacrifice and for ritual sacrifice which is prayer "in spirit and in truth"3. Remigius of Auxerre (end of the ninth century), in fact, gives the following explanation of the oremus before the secret: Ita autem potest intelligi... ut omnis populus oblationi insistere iubeatur, cum oblaturi intentionem suam offerunt, quatenus illorum oblatio accepta sit Domino4.

PROPITIU, favorably inclined, well-disposed ${ }^{5}$.

Here we have one of the oldest Latin words used to express man's basic sentiment toward the Higher Power. E. Norden calls it the expression of the most natural attitude of the ancients toward the deity as the protector of $\operatorname{man}^{8}$. How frequently it was employed in early Roman prayers can be seen in the material assembled by G. Appel in his work De romanorum precationibus". Even as in English "please" serves both as a mark of politeness and at the same time adds a certain urgency to a request, so too, the word, propitius, in the Orations ex-

1 Cf. Hofmann, op. cit., p. 93; J. Marouzeau, Traite de Stylistique latine, Paris 1954, p. 276.

2 Cf. Eduard Norden, Aus altrōmischen Priesterbüchern, Lund 1939, p. 18.

3 John 4, 23.

- PL 101, $1251 \mathrm{c}$.

5 Cf. Forcellini-de VIT, IV, p. 934.

- Cf. Norden, op. cit., p. 146.

7 p. 8-46, $122 \mathrm{f}$. 
presses the Church's respectful attitude toward God while giving utterance, at the same time, to her assurance of being "heard". Thus we have such phrases as: exaudi nos propitius, et concede, 212; or Ecclesiae tuae... dona propitius intuere, 515 .

This adjective reveals an exceptionally strong tendency to be used in fixed expressions. In 25 per cent of the \pm 60 times that it appears in the orations, propitius is found with the verb concede immediately following the relative clause of praise, as for example: Deus, qui conspicis, quia ex nostra pravitate affligimur: concede propitius: ut ex tua visitatione consolemur, 314. Then, there is a definite preference for the combination propitius respice which occurs ten times, always at the end of a phrase as in: preces populi tui supplicantis propitius respice, 319 ; and for respice propitius which occurs eight times at the beginning of a phrase: Respice propitius ad preces nostras, 757. The reason for the reversal of position is obviously to cede the place of emphasis to the verb. Finally, it occurs some seven times in conjunction with suscipe: suscipe propitius preces humilitatis nostrae, 217 . Thus we see how rigidly stylized the use of this adjective is. There is remarkably little variety in its employment. Its use with the three verbs - concede, respice, and suscipe - takes in 75 per cent of the times that it appears. The other times it occurs at various places in the prayers and with different verbs.

RESPICERE; see Terms which express the action of God in regard to the gifts, p. $89 \mathrm{f}$.

SACER, sacred.

The neuter plural, sacra, which was technical in the pagan mystery terminology ${ }^{1}$ occurs but once as a substantive in the orations: Haec sacra nos... potenti virtute mundatos ad suum faciant puriores venire principium, 595. Here it may be translated as "the sacred ritual act"; for always in the orations and especially in the secrets ${ }^{2}$ is the rite regarded as a unity ${ }^{3}$.

It is indeed interesting to note what words the adjective sacer modifies in the ORATIONS. This will give us some notion as to the precise meaning of the word itself in these prayers. In the first place there are the sacra mysteria: ut quae sacris sunt oblata mysteriis... tibi placeant, 26; ut eam, sacris mysteriis expiati, dignius celebremus, 571, 392, 1020; or the sacrum

1 Mohrmann, Etudes, I², p. 99, 233 ff.; Antibarbarus, II, p. 478; Forcellini-DE VIT, V, p. 285.

2 Cf. for example, 727, 1137 discussed on p. $138 \mathrm{f}$. under dicare as well as 158,585 , $717,1073$.

a This is supplementary to what Brov, Les Oraisons dominicales, p. 10, has to say. He translates sacra simply as gifts. 
mysterium: Sumpsimus... sacri dona mysterii, 1083, 469. The ritual act is called "sacred", "cultic", also when actio or oblatio is used instead of mysterium: sacris actionibus erudita, 898; Benedictionem nobis... conferat salutarem sacra semper oblatio, 81 .

Then, the altar is called sacer - whether that be the altar in the strict sense where the sacrifice proper is offered: me famulum tuum... dignum sacris altaribus fac ministrum, 743 ; qui me... sacris altaribus astare voluisti, 788; or whether it be what may be considered one of the extra tables on which the gifts were "heaped"1: quas sacris altaribus exhibemus, 619; Sacris altaribus... hostias superpositas, 1019. In both cases sacer indicates that they are objects set apart for cultic purposes. The privileges and duties peculiar to the bishop are referred to as sacer in the collect, pro defuncto sacerdote : quem... sacris muneribus decorasti, 844.

Holy Communion is called a sacrum munus: sacro munere vegetati, 576; see also $963,974,1022,1060,1175$; or a sacra participatio, 925 , thus emphasizing not only its holy, but also its ritual character. Once also this adjective is applied to the sacramental body of Christ: Corporis sacri, et pretiosi sanguinis repleti libamine, 150.

The official observance of the season of Lent is styled as: sacro nos purificante jejunio, 193; or sacrae... observationis jejunia, 989; or simply as: observationes sacras, 860 . This adjective lends a special coloring to servitus, the ascetical works of Lent, in the postcommunion for Fer. V. post. Dom. II Quadr.: quae (gratia) et sacrae nos deditos faciat servituti, 573 . The rite of matrimony is also "sacred": Suscipe... pro sacra connubii lege munus oblatum, 1132.

Thus we see that in all the instances mentioned, the adjective sacer refers to that which is set aside for God - either because it constitutes an official ritual action itself as mysterium, observantia, or lex; or because it is connected with the rite. There remains to be mentioned the one instance in which this word is employed in the same sense as it has in the name sacra scriptura for the Bible ${ }^{2}$. This is the case when there is mention of the song of Moses: ita erudire populum tuum sacri carminis tui decantatione voluisti, 205.

SAGRARE, CONSEGRARE, to dedicate to God in a ritual action.

Sacrare was one of the verbs used in pagan Latin for "to dedicate to the deity"; e.g., sacrare Capitolino Iovi donum ex auro, Suet., Tib., 53; divinique ossa parentis Condidimus terra, moestasque sacravimus aras, Verg. Aen. 5, 48.

1 C. p. 20, note 3.

C. Mohrmann, Etudes, II, p. 106. 
In the orations it has this same meaning. The secret, In ipsa die Dedicationis Eccl.: Deus, qui sacrandorum tibi auctor es munerum, 439; and that of St. Matthias: quas (hostias) nomini tuo sacrandas offerimus, 627, since they include the dative - tibi and nomini tuo - render it clear that the sense of sacrare is "dedicate to God". Then there are two other instances: Respice... propitius ad munera, quae sacramus, 986 and Fiat tibi... hostia sacranda placabilis, 563 . The use of the gerundive here is conspicuous. To this we shall return later.

This verb is used by metonymy in the sense of "to make holy" in the secret of the Nativity of Mary: matris integritatem non minuit sed sacravit, 1167. The adjective sacratus is applied to nox: hanc sacratissimam noctem, on Easter, 346, and on Christmas, 347. In these examples it undoubtedly means that the night has been made holy and therefore is so by reason of the great events which it has been privileged to witness, namely, the Resurrection and the Birth of Christ. But when there is question of plebs sacrata: Accepta tibi sit... sacratae plebis oblatio, 13, we think that it is a stylization introduced in order to lay stress on the

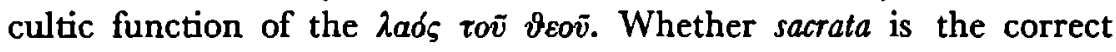
reading in the postcommunion for St. Callistus: ut reatus nostros munera sacrata purificent, 948, is a question. If it is, it is an unicum in the postcommunions. More usual is sacra with munera when this latter is used for participation in the Eucharist. See 576, 963, 974, 1022, 1060, $1175^{1}$. In fact, the Angoulême, the Paduense, and manuscript $\mathrm{O}$ of the Gregorianum have sacra. This seems to us to be the correct reading.

Consecrare occurs only once in a secret prayer: quas (oblationes) pro peccatis nostris nomini tuo consecrandas deferimus, 881. Only two remarks need to be made here. The use of the dative indicates that consecrare means "to dedicate to God" and not "to consecrate" in the modern sense which includes the concept of transubstantiation. Once again, the gerundive construction is used here. This verb is used also by metonymy to mean "to make holy by means of a sacrament": Deus, qui tam excellenti mysterio conjugalem copulam consecrasti, 434, in the prayer after the Pater Noster in the Missa pro Sponso et Sponsa. Once it gives expression to the notion that a day is sanctified by reason of the martyrdom of a Christian on that day: Deus... hodiernam diem... Petri et Pauli martyrio consecrasti, 352.

We return now to a consideration of the gerundive, which is relatively frequent in the ORATIONs, and the interpretation of which has a bearing on the meaning of the prayers involved. The employment of the verb sacrare in this form is the most noteworthy. It becomes the 1 See p. 144 and 167. 
more so if one glimpses at the use of this verb in the Veronense. In addition to 563 and 627 cited above, it has four other instances of secrets which employ the gerundive form:

Oblatio nos... sacranda purificet, 500

Tanto... placatus assume, quanto sacrandas nomini tuo has specialiter hostias indidisti, 922;

Sacrandum tibi... munus offerimus, 1225;

Adesto... muneribus... festivitate sacrandis, 1290.

What is more, these are the only instances in which the verb sacrare is used in reference to the ritual gifts ${ }^{1}$. Other related instances, in the ORATIONS, of the employment of the gerundive, in addition to those with sacrare and consecrare cited already, are the following:

et [ad $]^{2}$ sacrificium celebrandum... corpora, mentesque sanctificet, 581 ;

sicut nos sanctorum... natalitia celebranda non deserunt, 847;

ut quod mea $<$ celebrandum $>^{3}$ voce depromitur, tua sanctificatione firmetur, 743 ; Creaturis, quas ad fragilitatis nostrae subsidium condidisti, tuo quoque nomini munera jussisti dicanda constitui, 487 ;

Oblatio nos... tuo nomini dicanda purificet, 727;

Majestatem tuam... haec hostia reddat immolanda placatum, 671;

Hostias tibi... deferimus immolandas, 621 ;

Fac nos... his muneribus offerendis convenienter aptari, 554;

Quae visibilibus mysteriis sumenda ${ }^{4}$ percepimus, 841.

We have, no doubt, to do here with the basic import of the gerundive, in which neither future nor modal signification is present. In its original character the gerundive, like the gerund, indicates only the action in itself, and the tense and mood must be determined from the context ${ }^{5}$.

1 The secret: Propitius intuere munera... quae tuis altaribus exhibemus: ut quod nostra fragilitate defertur, tua virtute sacretur, MoHLBERG, Veronense, 595, does not fall into the same category as the other prayers cited above, because the subject of sacretur is quod, not munera, and quod refers to the whole ritual action; in the second place, sacretur means here "make holy", since it appears in a "kind of epiclesis formula". See p. 90 for a discussion of literary influence of epicleses upon offertory prayers and vice versa.

See p. 79, note 1 .

a The Veronense, Mohlberg, 964, has the text with celebrandum included; Gel. Vetus, Mohlberg, 775 has: quod mea celebranda voce; while later sources, e.g. the Fuldense, and Cod. Ross. lat. 204 of the X and XI century respectively, have dropped the gerundive entirely.

- The Veronense has celebrando here. See apparatus criticus in Bruylants, Les oraisons, II, no. 841.

- Cf. Persson, op. cit., p. 85 ff., esp. 97 f, 103 f.; I. Odelstierna, De vi futurali ac finali gerundii et gerundivi latini observationes, Uppsala 1926, passim; FR. Stolz - J. H. Schmalz - M. Leumann - J. B. Hofmann, Lateinische Grammatik ${ }^{5}$ (I - II, Munchen 
Whether the passive element was original in the gerundive ${ }^{1}$ and whether this basic force of the gerundive was created anew in Late Latin or, as Norberg believes, lived on in the depths of the colloquial language ${ }^{2}$, need not detain us here. The sense of the prayers quoted demands that the gerundive forms be translated passive. Thus oblatio... sacranda = oblatio quae sacratur; and natalitio celebranda $=$ natalitia quae celebrantur. Number 986, munera, quae sacramus has the same meaning as the munera sacranda. The same interpretation can be applied to 487 . The future idea is contained in jussisti... constitui, and munera dicanda $=$ munera quae dicantur ${ }^{3}$. This maintains the concept of the unity of the sacred action. Then, too, these prayers are very concrete and they apply to the action (dicanda, sacranda, celebranda, etc.) which is hic et nunc in progress. Two interpretations are possible for 554: Offerendis could be the dative of the gerundive to express purpose ${ }^{4}$, and the clause would mean: "make us capable of offering these gifts properly"; or offerendis may be the equivalent of quae offeruntur, and then we may translate: "adjust us to the gifts offered" (i.e. make our lives be in harmony with what we are doing ritually) ${ }^{5}$. This latter interpretation seems to us to be more in harmony with the general trend of ideas expressed in the secrets.

The reason for the use of the gerundives is surely stylistic. They add a certain broadness and loftiness to these prayers. That the gerundive was felt to have a solemnity and formality about it is seen from the fact that, as Löfstedt has it, "das Gerundivum ist in der volkstümlich gefärbten Sprache überhaupt niemals beliebt gewesen"6. It is certainly redundant in 841 and $743^{7}$. And still it emphasizes, in the latter, the official ritual character of the bishop's celebration of the liturgy - which

1926 - 1928), p. 594 ff.; Aalto, op. cit., passim; J. Svennung, Untersuchungen zu Palladius und zur lateinischen Fach- und Volkssprache, Uppsala 1935, p. 425 ff.; Norberg, op. cit., p. 199 ff.; Löfstedt, Kommentar, p. $156 \mathrm{f}$.

1 Cf. Aalto, op. cit., p. 135.

Op. cit., p. 200.

Odelstierna, op. cit., shows, however, that the final idea is sometimes included along with the present, cf. p. $22 \mathrm{f}$.

- The use of the dative of the gerundive to express purpose was rare in the high classical period, was more extended in Livy, freely used by Tacitus, and rare after Venantius Fortunatus. Cf. Stolz - Schmalz, op. cit., p. 598; WM. Most, The Syntax of the Vitae Sanctorum Hiberniae, Washington, D.C. 1946, p. 179.

3 Aptare is used with this meaning also in the postcom. for Dom. III post Epiph.: ut effectibus nos eorum veraciter aptare digneris, 957.

- Kommentar, p. 156. Cf. Aalto, op. cit., p. 145 f. and Odelstierna, op. cit., p. 56, who are of the same opinion.

7 See p. 146, note 3 . 
celebration (quod) he hopes to have "established by the sanctifying action of God".

It is very interesting to note that the gerundive appears frequently also in the ancient pagan Roman prayer formulae. Some examples are the following:

sacrificii acceptrices sitis VIIII agnarum feminarum et VIIII capranum feminarum propriarum immolandarum; harum renum ergo macte hac agna femina immolanda estote fitote volentes propitiae, CIL VI 32323, vs. $92 \mathrm{ff}$.

Iuppiter dapalis... eius rei ergo macte hac illace dape pollucenda esto, Cato, De agr., 132;

Iane pater, te hac strue ommovenda bonas preces precor, ibid., 134, 2 ;

Iuppiter de hoc ferto obmovendo... Fane pater, uti te strue ommovenda bonas preces bene precatus sum,... macte hisce suovitaurilibus lactentibus immolandis esto, ibid., 141, $2 \mathrm{f}$.

ejus rei ergo te hoc porco piaculo immolando bonas preces precor, ibid., 139

In these it may simply represent the early usage of the gerundive in its basic original meaning; while in the ORATIONS we may consider it a definite striving for effect.

SACERDOS, one who has priestly powers, bishop ${ }^{1}$.

Drawn from the sacral language of Rome, sacerdos had, in Early Christian Latin, no hierarchical meaning as did episcopus, presbyter, and diaconus; but it simply designated "one who performed the priestly functions", "a mediator between God and man". In the orations it is used to designate a bishop, Deus, tuorum gloria sacerdotum, 464; inter apostolicos Sacerdotes (for a departed bishop), 375. The three prayers now used Pro defuncto sacerdote; viz., collect, 844, secret, 1119, postcommunion, 851, are taken from the Gel. Vetus ${ }^{2}$, where the title is: Item alia pro sacerdote, but in each prayer stands: famuli tui illius episcopi.

SUPPLEX, humbly submissive ${ }^{3}$.

Though not originally a technical term in pagan Roman religion, supplex found its way frequently into Roman prayers since Virgil and Livy, especially in the poets. G. Appel gives the following explanation: "Nam ut homines rogantes misero habitu hominum animos tangunt, ita precantes gestibus miserabilibus deorum mentem miseratione permovere conantur"4.

In the orations, too, it is used no doubt for its affective character.

1 Cf. Janssen, $o p$. cit., p. 82 f., 245 f.

2 Mohlaerg, 1633, 1637, 1635 respectively.

a Forcellini - de Vit, V, p. 776; Antibarbarus, II, p. 573.

4 APpel, op. cit., p. 200. 
It is an emphatic term for man's lowly position before God in prayer. Once again we find here regularly recurring fixed expressions: supplices te deprecamur, 72, 104, 961, 970, 1022, 1026; misericordiam (or clementiam) ... supplices deprecamur, 644, 781; supplices te rogamus ${ }^{1}, 101,382,1099$, 1100,1103 ; and te supplices exoramus, 208, 802, 220; or majestatem... supplices exoramus, $668,765,794$. In all of these cases supplices does nothing more than accent the fact that we are aware of our true position before God, and that our attitude in prayer must be that of a humble beggar.

There remains but to mention the fact that supplices is used as a noun six times: praesta..., 320, 791; largiri..., 199; miserere supplicibus tuis, 338; and exaudi supplicum preces, 541 ; merita supplicum, 770 . Here it has the same stylistic effect that the adjectival form has.

SUPPLICARE, to beg humbly².

As a finite verb, supplicare does not appear in the ORATIONs. Once it occurs as a gerund: Deprecationem nostram... benignus exaudi: et quibus supplicandi praestas affectum, tribue defensionis auxilium, 197. Here we may consider that it is used merely for the sake of variety, since another word for prayer, deprecatio, has already been used. Thus supplicandi affectum is simply "the desire to pray".

In all the other instances of its use, it appears in the present participial form. Usually it is a participle properly so called-modifying populus, 319, 321, 527, 1181 ; famulus, 666; nos, 603, 758; familia, 843; or Ecclesiae, 979. Sometimes, however, it occurs as the Late Latin substantive ${ }^{3}$ in the plural: Animabus... famulorum famularumque tuarum oratio proficiat supplicantium, 52; ut, quae tibi tuo grata sunt instituto, gratiora fiant patrocinio supplicantis ${ }^{4}, 57$.

SUPPLICATIo, prayer, entreaty, intercession ${ }^{5}$.

This was in Roman religious language the technical term for the public celebration of thanksgiving or petition during which the temples were opened and the images of the gods brought outside on couches while the pontifex performed the sacra. After the strictly technical mean-

1 This was a favorite expression in the Veronense where it occurs 13 times. Cf. BruYlants, Concordance.

2 APPEL, op. cit., p. 67.

- Cf. Mueller, op. cit., p. 26.

- N.B. this was originally plural in the prayer designated for In natale apostolorum Petri \& Pauli III (Veronense, Mohlberg, 284), but when the prayer was used for the feast of the Conversion of St. Paul, supplicantium had to be changed to the singular. B Cf. Wissowa, Religion und Kultus, p. 423; Antibarbarus, II, p. 574; ForcelliN - DE VIr, V, p. 774. 
ing disappeared with the overthrow of paganism in Rome, the word came to be employed for prayer to God.

It is used in the ORATIONs for prayer in general: supplicationes populi tui clementer exaudi, 773. Intercessory prayer is also designated as supplicatio: Da... fidelibus populis Sanctorum tuorum semper veneratione laetari: et eorum perpetua supplicatione muniri, 180. No doubt the similarity to supplex and supplicare has given it a special nuance of humble entreaty. But what is most striking about this noun is its use in set phrases: Adesto, Domine, supplicationibus nostris occurs 9 times: 28, 29, 30, 31, 32, 37, 38, 39, 223. Propitiare, Domine, supplicationibus six times: $901-905$. Note that this latter means "Be kindly disposed to our prayers", even as does the expression: Propitius esto... supplicationibus nostris, 908.

SUPPLICITER, humbly and earnestly.

This adverb displays the same tendency as does supplex. It occurs largely with the same verbs - ten times with deprecari: $381,451,623$, $626,669,710,739,906,1041,1076$; four times with exorare: 195, 625, 690,815 ; and once with implorare, 972, and flagitare, 769, respectively. That the word is used for emphasis and stylistic reasons is further brought out by the fact that humiliter, which was much more colloquial in Christian Latin, is used only twice with words of praying: humiliter deprecantes, 1083, and humiliter implorantibus, 769.

VENERARI, to worship with religious awe, to honor with religious rites.

This verb, which in Roman cultic language means "to honor the gods with reverence and ritual service in order that they might be moved to grant the favors requested"1, is never in the ORATIONs referred directly to God; but it does include the notion of performing religious rites. This is evident, for example, in the collect for Sabb. in Albis: Concede... ut qui festa paschalia venerando egimus, per haec contingere ad gaudia aeterna, 135. Here venerando means not "reverently", but "by means of religious rites". When the verb is applied to feasts of saints, it also means more than "to honor" in the sense of "to regard with esteem". It includes the notion of "performing a sacred action in honor of". Sometimes the ritual element is explicitly mentioned, as in: ut quos veneramur obsequio, eorum pium jugiter experiamur auxilium, 77; ut quam veneramur officio, etiam piae conversationis sequamur exemplo, 399; palmas incessabili devotione ${ }^{2}$ venerari, 163; quae extrinsecus annua tribuis devotione venerari, 539; qui nos omnium Sanctorum tuorum merita sub una tribuisti celebritate venerari, 792. Hence we may assume that where the verb is used alone 1 Cf. Appel, op. cit., p. 67; Antibarbarus, II, p. 654; ForGellnvi - DE VIT, VI, p. 247.

2 Devotio means "the cultic action"; cf. p. 97 f. 
in: Gloriam... sanctorum Apostolorum... perpetuam venerantes, 571 , it also contains a ritual connotation. The postcommunion for the Beheading of St. John the Baptist is somewhat uncertain:

Conferat nobis... sancti Joannis Baptzstae solemnitas:

ut et magnifica sacramenta

quae sumpsimus

significata veneremur

et in nobis potius edita gaudeamus, 142

Obviously, significata is juxtaposed to edita, and veneremur to gaudeamus; significata refers to the external rite and edita to the inner effects produced by the rite. We would suggest as a translation the following: "May the festal celebration in honor of St. John the Baptist, O Lord, give us the privilege to perform ritually (veneremur) the great sacrament which we have received, in so far as it is an external sign (significata), and even more to rejoice over it in so far as it has produced effects (edita) in us".

The verbal noun veneratio is used in the same sense as solemnitas; viz., "the liturgical celebration as a whole", 1 which is the "occasion" on which we offer the Eucharist: in cujus veneratione haec tua obtulimus, 1089; and the source of public joy: Da... populis Sanctonum tuorum semper veneratione laetari, 180.

\section{B. LEGAL TERMS}

That the similarity between the language of prayer and the language of law in ancient Rome reflects something of the psychological and religious attitude of the Roman people is generally conceded ${ }^{2}$. There is in both the same tendency for precision, for an accumulation of words where one term would have expressed an idea adequately, and the same almost scrupulous care lest anything be said amiss. This naturally gave rise to a certain redundancy of style, which is so characteristic of pagan Roman prayers as well as of Roman legal formulae. This juridical character was, to a certain limited extent, inherited by Christian Roman prayer. The Canon Missae, for example, reveals a great fondness for abundance and for pleonastic expressions. However, this may be more a stylistic device to create a lofty atmosphere than a

1 Cf. p. 113.

Cf. Appel, op. cit., p. 145; Chr. Mohrmann, Review of M. G. Haessly, Rhetoric in the Sunday Collects of the Roman Missal (Cleveland, Ohio 1938), REL 17, 1938, p. 414; J. Marouzeau, Quelques aspects de la formation du latin littéraire, Paris 1949, p. 97 ff.; Norden, Aus altrömischen Priesterbüchern, p. 12; J. B. Pight, La poesia religiosa romana. Testi e frammenti per la prima volta raccolti e tradotti, Bologna 1958, p. 14. 
striving for precision ${ }^{1}$. The orations display even less of a legalistic tendency. However, pleonastic turns of speech are frequent. To quote but two examples: exaudi preces populi tui, et praesta, 392; Inclina, Domine, aurem tuam ad preces nostras, quibus misericordiam tuam supplices deprecamur, 644. Here again pleonasms are introduced for stylistic reasons.

However, a study of stylistic devices is not the object of our research. Ours is a vocabulary study. Our aim is to find out which words from legal terminology have found their way into the orATIONs, and to explore the meaning of these terms within the context of these prayers. No doubt, it is true that many of these words have been introduced precisely for their stylistic value, i.e., for the sake of expressivity, concreteness or emphasis. Even though a careful study of style would be very valuable, we must set it aside here and limit ourselves to the more basic task of studying the legal terms in their context in order to determine their precise meaning and function.

ADSCRIPTUS, officially inscribed ${ }^{2}$.

In its proper legal sense this adjective means "being inscribed officially on the census record of a given locality". It has a figurative meaning in the secret Pro vivis et defunctis: ut... omnium fidelium nomina, beatae predestinationis liber adscripta retineat, 209. The notion of a liber predestinationis is a combination of the Hebrew "Book of Works" and "Book of Life". Thus being inscribed in the beatae predestinationis liber is a metaphorical expression for salvation by grace and good works. We have here, then, a technical legal term used in conjunction with one which had a Hebrew origin and a specifically Christian development. Such a combination of heterogeneous elements is a rather rare phenomenon in the orations.

COMMENDARE, to recommend, to cause to appear valuable ${ }^{3}$.

The proper sense of this verb is "to hand over, to commit to". This is its meaning also in Ps. 30,6 and in: Pater, in manus tuas commendo spiritum meum, Mt. 10,37; Lk. 23,46. Early Christian inscriptions show that this verb was used in the sense of "to recommend". The Christians recommended themselves to the departed - especially to the apostles and martyrs - in order that these in turn would commend them to God.

I C. Mohrmann, VC 4, 1950, p. 15 f.

2 Cf. Heumann-Seckel, p. 18; Leo Koep, Das himmlische Buch in Antike und Christenเum. Eine religionsgeschichtliche Untersuchung zur altchristlichen Bildersprache, Bonn 1953. p. $81 \mathrm{ff}$.

3 C. TLL III, p. 1840; Antibarbatus, I, p. 271 ; HeumanN-Seckel, p. 79; R. LeONHARD, art. commendare, Pauly-Wissowa, IV, p. 722; DeLEHAYE, Les origines du culte des martyrs, p. 128; DiehL, op. cit., 2302, 2409, 4823. 
In the ORATIONs, however, a kind of legal stylization is employed when there is a question of imploring the intercession of the saints. The saints are not invoked directly, but rather is there expressed the hope that the prayer (oratio) or the supplication (supplicatio) of the saints may render the gifts and prayers of the faithful "commendable": Preces et hostias beati Petri Apostoli commendet oratio, 516; quae (munera) majestati tuae beati Nicomedis Martyris commendet oratio, 1108; Sanctorum... confessio: quae et munera nostra commendet, 1055; Supplicationibus beati Matthaei... commendetur oblatio, 1096; Munera nostra... apud clementiam tuam Dei Genitricis commendet oratio, 692. Commendare here acquires the sense which it had in legal language; viz., "to render valuable, to increase the value of". Even when there is a request that we personally be recommended to God the legal figure is evident, for we have clauses like: Beatorum martyrum... nos festa tueantur : et eorum commendet oratio veneranda, 75 ; Intercessio nos... beati $\mathcal{N}$. Abbatis commendet, 651 .

EXHIBERE, to produce in public, exhibit, fulfill a duty.

This verb, beloved by lawyers and by Tertullian in particular, became in later times ever more frequent. As a technical legal term, it means "to issue a court summons", "to produce the bodily presence of", and also "to pay homage to" or "to fulfill an official public duty"1. It is in the last sense that the word is applied to the performance of a sacred rite or function: ut observantiam ${ }^{2}$ quam corporaliter exhibemus, mentibus etiam sinceris exercere valeamus, 643 ; ut in cujus honore solemniter (sacrificium) exhibetur, 1015; liberam servitutem tuis semper exhibeamus officiis, 541. The broader sense of "to perform a duty" includes more of a moral connotation, but still it may be interpreted as being a transferred sense of the legal terminology in the following: et congruam tibi exhibeat servitutem, 82; puram tibi exhibeant servitutem, 346; gratias exhibentes, 938 . This is the more evident since servitus is sometimes interpreted in these prayers as "an official act of public worship"3. When this verb is used to represent the act of placing gifts upon the altar in the offertory rite, as the secret of Dom. XII post Pent. has it, it lays stress on the fact that this action of bringing gifts is the performance of an official public service: Hostias... propitius intende, quas sacris altaribus exhibemus, 619. This is even more striking when exhibere is juxtaposed to the other ritual act of the people - the reception of the consecrated gifts: Concede nobis... ut his muneribus, ...et te placemus exhibitis, et nos vivificemur acceptis, 119.

1 Cf. TLL V, p. 1416 ff.; Heumann-Seckel, p. 189.

2 Lent is considered as an official liturgical function. See observantia, p. $111 \mathrm{f}$.

- Cf. seroitus, p. $170 \mathrm{f}$. 
Only once does this verb occur in its very general meaning of "to show outwardly" or "to display": concede nobis verae humilitatis virtutem, cujus in se formam fidelibus Unigenitus tuus exhibuit, 450.

EXPEDIRE, to disentangle, to free from accusation.

The freedom from sin which is the effect of the sacred action, is expressed by this legal term: Da... ut haec salutaris oblatio et a propriis nos reatibus indesinenter expediat, 158; Mystica nobis... prosit oblatio: quae nos et a reatibus nostris expediat, et perpetua salvatione confirmet, 717 ; Praesta... ut anima famuli tui, his purgata sacrificiis et a peccatis expedita, indulgentiam pariter et requiem capiant sempiternam, 845.

The term was also used with a medical connotation meaning "to give relief from illness". It is the medicinal operation of the Eucharist which can deliver us from the sickness which is our own perversity: Tua nos... medicinalis operatio et a nostris perversitatibus clementer expediat, 1146.

EXSISTERE, to be'.

Illustrative of the liturgy's tendency to be precise, this verb is used with no trace of the local nor of the philosophical connotation. It means in the orations "to appear", "to be found", or simply "to be". In: pro qua sanctus Gorgonius Martyr interventor exsistat, 572; and Andreas Apostolus exstitit praedicator et rector, 670, it coincides perfectly with legal terminology. In basically the same sense, but including a slight hint of duration of time, it occurs in: quae (virgo) tibi grata semper exstitit, 647; and sine quibus (sacrificiis) a culpa nemo liber exstitit, 606. Whether we should translate exsistit by "remains" or by "is" in: populum tuum ad te revertentem propitius respice; ut, dum tibi devotus exsistit, iracundiae tuae flagella ab eo clementer amoveas, 395, will depend on whether we interpret dum as causal or as temporal ${ }^{2}$. It seems to us that the causal interpretation is the better. A striving for effect seems to be the only reason for its use in: beatae Virginis partus exstitit salutis exordium, 559; and ut tibi (munera) grata sint, et nobis salutaria semper existant, 986.

Familia, the assembly of the Christians ${ }^{3}$.

Here we have to do with a term which is part of Roman legal terminology. Though not so frequent as ecclesia, it has the same concrete technical sense: $346,538,556,557,558,843,856,857,935,976$,

1 Cf. TLL V, p. 1868 ff.; Heumann-Seckel, p. 189.

2 Cf. R. Kühner - C. Stegmann, Ausführliche Grammatik der lateinischen Sprache, (I-II, Hannover 1955), II, p. 377.

a Cf. Heumann-Seckel, p. 190; TLL VI, 1, p. 234 ff.; Botte-Mohrmann, op. cit., p. 77. 
$987,1060,1157$. It does not seem that the word retained in these prayers much of its original connotation as the assembly of all the members of a household - wife, children, and slaves - under one paterfamilias. More likely is it that the word was used simply as a stylistic variation. This is certainly the case when its synonym also is present: Deus, qui Ecclesiam... purificas: praesta familiae tuae, 327 . Only once does it display a further semantic development. In the collect, Pro congregatione et familia: Defende... istam ab omni adversitate familiam, 196 , it has the narrower and profane sense of "family". However, this meaning has been later appropriated to the word; for this prayer appears first in the Veronense for the feast of St. Michael ${ }^{1}$, where familia has the earlier sense. A curious grammatical phenomenon occurs four times with this word. It is this: a first person plural verb or pronoun follows familia: Exaudi preces familiae tuae... et praesta; ut sancta haec, quae a te sumpsimus, 538; Respice... familiam tuam: et praesta; ut apud te mens nostra... fulgeat, 976; Satiasti... familiam tuam muneribus... nos refove, 1060; Tuere... familiam tuam, ut... requiremus, 1157. This is evidence of how intimately the praying community was conscious of its being the familia Dei.

INDULGENTIA, kindliness, bounty, forgiveness of sins.

From its primary meaning of "leniency" or "tenderness", this word became, especially under the empire, a technical term for exemption from punishment granted by the emperor to one convicted of a crime ${ }^{2}$. From this it developed in church law the technical sense of "indulgence" as we think of it today; viz., the remission of temporal punishment due to sin. However, its use in Christian language shows that its development was not so simple and direct. Beside bounty, which meaning was frequent in Christian authors ${ }^{3}$, indulgentia took on the sense of "forgiveness of sins", or more specifically even of the official pronouncement of that forgiveness in the rite of the reconciliation of penitents. Thus Holy Thursday was sometimes called dies indulgentiae ${ }^{4}$ because the rite was generally performed on that day.

For the most part, indulgentia is employed in the orAtions in a legal connotation and means "forgiveness". This legal content is emphasized by the fact that frequently indulgentia is represented as being sought through the intercession of the saints: Sanctorum tuorum... nobis pia non

1 Mohlberg, 852.

2 Cf. TLL VII, p. 1244 ff.; R. KLeinfeller, art. indulgentia, Pauly-Wissowa, IX, 2, p. 1378; HeumanN-Segkel, p. 262.

3 Cf. Blaise, Dictionnaite, p. 436; TLL VII, p. 1246 ff.

- Cf. Rheinfelder, Kultsprache, p. 137 ff. 
desit oratio: quae et munera nostra conciliet, et tuam nobis indulgentiam semper obtineat, 1057; ut cujus venerandam celebramus festivitatem, precibus ejus indulgentiam consequamur, 225; Indulgentiam nobis... beata $\mathcal{N}$. Virgo et Martyr imploret, 647; Exaudi... preces nostras: et interveniente beato Marco, indulgentiam nobis tribue placatus et pacem, 528; quae (Sanctorum Martyrum... confessio) et munera nostra commendet, et tuam nobis indulgentiam semper imploret, 1055. In the collect In Missis quot. defunct., too, forgiveness is petitioned for the faithful departed through the prayers of their brethren on earth: ut indulgentiam, quam semper optaverunt, piis supplicationibus consequantur, 567.

Together with absolutio and the Christian new form, remissio, indulgentia became a technical expression for the "forgiveness of sins". This is clear from phrases like: peccatorum indulgentiam mereamur, 127, 156; indulgentia delictorum, 338, 732; or indulgentiam... culparum, 1040. Furthermore, the fact that it is used so frequently without a modifying genitive shows how technical it had become ${ }^{1}$. In addition to those examples quoted: 1057, 225, 647, 528, 1055, there are also the following: Gratiam... cordibus nostris clementer infunde: quae... optatae nobis, te largiente, indulgentiae praestet effectum, 574 ; largire... fidelibus tuis indulgentiam placatus et pacem, 661; da nobis ita Dominicae passionis sacramenta peragere; ut indulgentiam percipere mereamur, 760 ; propitiare muneribus: ut hac oblatione placatus, et indulgentiam nobis tribuas, et postulata concedas, 899. Indulgentia refers specifically to the forgiveness of the sins, committed after Baptism in the phrase of the secret ad postulandum continentiam: salva nos per indulgentiam, quos dignatus es salvare per gratiam, 472 . In the secrets for Dom. XII post Pent. and for 29 July respectively, indulgentiam is represented as one of the fruits of the sacrifice, and as such it must mean the state of soul after the forgiveness has been granted: Hostias... propitius intende... ut nobis indulgentiam largiendo, tuo nomini dent honorem, 619; Hostias tibi... deferimus: suppliciter deprecantes; ut indulgentiam nobis pariter conferant, et salutem, 626.

The pleonastic group indulgentia tuae propitiationis, 545, 756, 949, which we may best translate by "merciful forgiveness", lays stress on the fact that forgiveness is the effect of God's bounty. Similarly, in a prayer like: Deus, qui populis tuis indulgentia consuleris, et amore dominaris, 432 , the context clearly indicates that "kindness" or "tenderness" is meant. So, too, if we interpret indulgentiae as a genitive of definition

1 N.B. the prayer: Indulgentiam, absolutionem, el remissionem peccatorum nostrorum tribuat nobis omnipolens et misericors Dominus. The usage of indulgentia in the ORATIONs does not indicate any clear-cut distinction between remissio as "forgiveness" and indulgentia as "remission of punishment". But cf. Botte-Mohrmann, op. cit., p. 61, note 4. 
rather than a subjective genitive, we must translate it by "bounty" in: tuae sumamus indulgentiae largitatem, 659 . The same holds for: Ut nobis... tribuis solemne tibi deferre jejunium: sic nobis... indulgentiae praesta subsidium, 1171.

INDULGERE, to be lenient, to forgive ${ }^{1}$.

This verb is far from having in the orations so technical a sense as its nomen actionis has, even though indulgere does occur in Christian literature as "to forgive". Only once does it mean "to forgive" in the legal sense; viz., in the postcommunion for the Mass for the faithful departed: ut quidquid conversatione contraxerunt humana, et clementer indulgeas, 1097. It usually has the Post-Augustan sense of "to confer a favor": quibus fiduciam sperandae pietatis indulges, 38 ; tuis semper (sc. benedictio) indulgeat beneficiis gratulari, 565; participatio indulta convivii, 916 .

INTERCEDERE, to plead in behalf of ${ }^{2}$.

Found first in Suetonius (Caes. 30) in the sense of "to bring intercession for" or "to become a surety for", this technical legal term was early sanctified by its frequent use by Christian authors to indicate the intercession of the Church triumphant for their militant or suffering brethren. From the material collected by Delehaye ${ }^{3}$ and, more recently, by Diehl ${ }^{4}$, it is clear that from earliest times the Christians were wont to ask the departed to pray for them. Those thus invoked were any of the departed - a father, a mother, a son, a spouse - who had died after Baptism. Such invocations as: Roga pro nobis (DIEHL, 2343), and Pete et roga pro fratres et sodales vestros (DIEHL, 2315) bear witness to a belief in the intercession of those who had gone before. The inscriptions show, too, that it was not only the martyrs who were thus called upon. After the peace of Constantine, however, such invocations began to be limited more and more to the martyrs and later on, to other holy people who were revered as "saints".

In the ORATIONs, the saints are never prayed to directly. Still the theological fact of their intercessory power is clearly expressed in prayers like: Adesto nobis... et, intercedente pro nobis beato Thoma Apostolo, tua circa nos propitiatus dona custodi, 35 . Two things are to be noted here. In the first place the usual words employed in the inscriptions to

1 G. TLL VII, p. 1250 ff.; Heumann-Seckel, p. 262.

Cf. Antibarbarus, I, p. 701 f.; Heumann-Seckel, p. 278.

- Cf. Delehaye, Les origines du culte des mattyrs, p. $123 \mathrm{ff}$.

- Cf. Diehl, op. cit., 2324, 2332-2337, 2343-2348. N.B. petere occurs in the orations six times, always in prayers of petition made directly; rogare occurs only in the one fixed expression: supplices te rogamus; see p. 119 and 121 . 
express the act of "intercession" of the faithful departed - petere and rogare - are here replaced by the more solemn verb intercedere, and the whole prayer is cast into a kind of legal mold. It is through the saint's mediation that we expect to receive a favorable hearing with God. In the second place the truly Christian concept of the saint's power as being purely intercessory is maintained in strict theological accuracy. The assurance that the martyrs especially were able to interpose their credit with God on behalf of the Church ${ }^{1}$ finds expression in such prayers as: ut, Sanctorum tuorum (Abdon et Sennen) intercedentibus meritis, ab omnibus mereantur adversitatibus liberari, 442; and qui tibi digne meruit famulari, ejus intercedentibus meritis, ab omnibus nos absolve peccatis, 540. Although this latter quotation occurs in the MR today in the collect for St. Leo the Great, who was a confessor, it was used in the Gel. Vetus for St. Marcellus I, pope and martyr. ${ }^{2}$ See also intercedentibus martyribus below.

There is a second stylistic element to be noted in regard to the use of intercedere. This has to do with the construction in which it is used. In only three instances does it appear in any construction other than the ablative absolute: Protegat nos... beatus $\mathcal{N}$. pro nobis intercedendo, 915; ut ipsam pro nobis intercedere sentiamus, 440; ut apud te... intercedat, 692. The ablative absolute construction was rather general in legal terminology ${ }^{3}$; this may have been a contributing factor to its frequent recurrence in the orations. Indeed, a phrase like: intercedentibus Martyribus, constitutes a kind of standard insertion, almost an entity in itself, very loosely connected to the rest of the prayer. In fact, prayers originally used for other occasions are sometimes made to fit the feast of a particular saint simply by the addition of the ablative absolute: intercedente beato Martyre tuo, $\mathcal{N}$. To mention but a few examples: the postcommunion for Dom. V post Epiph.: Quaesumus... ut illius salutaris capiamus effectum, cujus per haec mysteria pignus accepimus, 940 , is made to apply to the feast of the martyrs on 10 July simply by the insertion of: intercedentibus Santis tuis. The postcommunion: Refecti participatione muneris sacri... ut cujus, exsequimur cultum sentiamus effectum, 963, which appears in the Veronense: In ieiunio mensis quarti", is especially prolific

1 Cf. Delehaye, Les origines du culte des martyrs, p. 475 f.; P. Dörfler, Die Anfänge der Heiligenverehrung nach den römischen Inschriften und Bildwerken, München 1913, p. $15 \mathrm{ff}$.

2 Mohlberg, 810. St. Marcellus is honored by the Church as a martyr though he actually died in exile for the Faith.

- Cf. Heumann-Seckel, p. 278.

- Mohlberg, 230. 
in the MR. By the simple insertion of intercedente (-ibus) beato (sanctis) $\mathcal{N}$., it is made to fit 23 feasts of martyrs ${ }^{1}$. So, too, the postcommunion for the Sunday after Ascension, 974, is identical with that of the Martyrs Felix and Audactus, except for the addition of intercedentibus Sanctis tuis in the latter. And so examples could be multiplied; e.g. $1026,1065,1087$. The reverse process is also sometimes the case. For example, the postcommunion, 878, for Ss. Perpetua and Felicitas ${ }^{2}$ has been adapted to Feria II post Dom. III Quadr. by the omission of intercedentibus sanctis.

The collect for Monday of Holy Week has employed this verb in reference to the sacred Passion of Christ: $u t$ qui in tot adversis ex nostra infirmitate deficimus; intercedente unigeniti Filii passione respiremus, 192. Here the word has a deeper meaning than the usual sense in which it is applied to the intercessory power of the saints. The Epistle to the Hebrews 9,15 is undoubtedly the inspiration for this phrase. It speaks of the mediatorship of Christ: Et ideo novi testamenti mediator est: ut morte intercedente, in redemptionem earum praevaricationum... repromissionem accipiant qui vocati sunt aeternae hereditatis. Hence we may say that it refers here to the real mediatory power of the Passion of Christ which is the meritorious cause of the supernatural grace which "revives" (respiremus) us.

INTERCESSIO, the act of pleading in behalf of; the prayer of the saints on behalf of the faithful ${ }^{3}$.

From the meaning which this noun had in Roman political life; viz., the interposition of a veto by a magistrate, intercessio came to mean in legal terminology "the entrance of a third party between two others in order to protect the one against the other". It was used especially for the act of becoming a surety for another who wished to borrow money. Like the verb from which it is formed, this noun bears witness to the widespread recourse to the intercession of the saints; on the other hand, it was also a kind of stopgap in prayers on feasts of saints. Petition is made that the sacrifice be pleasing to God by reason of the intercessio Sanctorum, e.g. ut quae sacris sunt oblata mysteriis, tuorum tibi placeant intercessione Sanctorum, 26. See also 842, 984, 1050, and 1144. It would seem unnecessary to quote all the examples in full since they

1 It is true that this number includes 19 feasts which fall beyond the time limit set for this work. Still it shows how the trend seen in the earlier prayers has continued on down to modern times.

2 Veronense, MohlBerg, 1207.

3 Cf. Heumann-Seckel, p. 278; R. Leonhard, art. intercessio, Pauly-Wissowa, IX, 2, p. 1602 ff.; Forcellani-De Vit, III, p. 568. 
are so much alike. Sometime a favor is sought through their mediation, e.g. et intercessione beati Laurentii Martyris tui... perpetuam nobis misericordiam benignus impende, 29, 32, 66, etc.

Once again, it is a fixed construction in which this word appears. In only four of the 37 instances of its occurrence does it appear in any other than the ablative case - twice in the nominative: ita nos ejus intercessio... reddat acceptos, 74 ; nos intercessio tueatur, 76 ; and twice in the accusative with per: per intercessionem, 881, 973. One does not find, however, so much interchange of prayers for feasts by the addition or omission of intercessio as we have seen to be the case with intercedere; probably because the ablative of means is more closely bound to the rest of the sentence, while the ablative absolute has a greater tendency to become an independent member. The only instance of such interchange is the secret for the third Mass of Christmas: Oblata... munera nova Unigeniti tui Nativilate sanctifica: nosque a peccatorum nostronum maculis emunda, 723, which is also used for the Vigil of Ss. Peter and Paul with the addition of: Apostolica intercessione.

As to the meaning of the word, one instance is exceptional: ut hoc sacramentum non sit nobis reatus ad poenam, sed intercessio salutaris ad veniam, 923. Here it refers to the effect of the reception of the sacrament.

INTERCESSOR, a guarantor, one who prays for another ${ }^{\mathbf{1}}$.

Nomina auctorum in -or or -tor are comparatively rare in the ORATIONS in general ${ }^{2}$. The fact that these words seemed not to match so well with the lofty style of these prayers, plus the frequency of the present participle of intercedere, in the ablative absolute construction, have all but obliterated the noun intercessor entirely. It occurs but twice: (a) for the feast of All Saints - also in an ablative absolute - multiplicatis intercessoribus, 792; and (b) for the feast of St. Andrew: ut sicut Ecclesiae tuae beatus Andreas Apostolus exstitit praedicator et rector, ita apud te sit pro nobis perpetuus intercessor, 670. In this latter it helps to create a truly legal atmosphere; but it was introduced certainly as much for the sake of a balanced construction and rime as for its juridical content.

INTERVENIRE, to pray for, to intercede for.

In legal terminology this verb has basically the same sense as inter-

1 Cf. Heumann-Seckel, p. 279.

2 adjutor 1 , amator 5 , auctor 12 , benefactor 1 , conditor 1 , confessor \pm 10 , cultor 1 , dispositor 1 , doctor (gentium) 1, dominator 1, impugnator 1 , institutor 1 , intercessor 2, interventor 1, largitor 4, miseralor 1, pastor 8, peccator 5, persecutor 1, praedicator 1, protector 4, rector 5, redemplor 4, remunerator 1, restitutor 1 , salvator 3 , sanctificator 1 , sator 1 , susceptor 1 . 
cedere ${ }^{1}$; but it includes also the idea of "the assumption of another's obligation". In the ORATIONs it has the same meaning as intercedere and follows the same trend as far as construction is concerned; but it is far less frequent. It occurs only six times - five times in the familiar ablative absolute construction, loosely bound to the rest of the prayer: interveniente evangelista Luca, 514; 528, 623, 861, 1082; and once in the subjunctive: Interveniat pro nobis... sanctus tuus Lucas, 653.

Interventor occurs but once, and this in a typically legal context: pro qua sanctus Gorgonius Martyr interventor exsistat, 5722. Interventio, too, has the same meaning as intercessio: ut ejus interventione, tuae circa nos pietatis semper viscera sentiamus, 298; ejus... interventione nos refove, 1060.

A curious fact is to be noted in regard to the use of this verb. In the Veronense, intervenire occurs seventeen times, while intercedere appears only six times. In the orations, on the other hand, intercedere is used five times as often as intervenire. Perhaps this indicates that intervenire has simply the Late Latin meaning of "to intercede, to pray for"3, and that it is not really a legal stylization at all. However, it would be very dangerous to generalize here, for intervenientibus sanctis, which occurs ten times in the Veronense 4 , may have been a personal preference of an author. In any case, intercedere is theologically the more accurate word, since the role of the saints is to plead in behalf of the faithful on earth, but not to intervene in the strict sense of the word.

MERITUM, that which one deserves, value, worth, dignity.

Even in ordinary legal terminology this noun meant not only what one has earned, but also "value, worthiness". Its sense was neutral." In referring to Judas and to the good thief in the collect of Holy Thursday, it is employed so as to include both elements: ut sicut in passione sua Jesus Chr. Dom. $\mathcal{N}$. diversa utrisque intulit stipendia meritorum, 200. Strictly in malam partem it occurs but once: Concede... ut qui, ex merito nostrae actionis affigimur, tuae gratiae consolationis respiremus, $134^{6}$.

According to the strict law of retribution, man's merits are always wholly inadequate before God. Hence, even when meritum is used in bonam partem, it occurs in contexts indicating this deficiency. In order

1 Cf. Heumann-Seckel, p. $286 \mathrm{f}$.

2 The Gel. Vetus, Angouleme, and St. Gallen read intervenit instead of interventor exsistat. See apparatus criticus in BruYlaNTs, Les oraisons, II, p. 156.

- Cf. A. Souter, A Glossary of Later Latin to 600 A. D., Oxford 1949, p. 216.

4 Cf. Index Verborum in Veronense, Mohlaerg, p. $319 \mathrm{ff}$.

- Cf. TLl VIII, p. 814 ff.; Heumann-Seckel, p. 340; Botte-Mohrmann, op. cit., p. 85, note 6 .

- Cf. Brou, Les oraisons dominicales, p. 91. 
to compensate for what is lacking in human merits, recourse is had either to God's merciful help: quem nullis suffragantibus meritis, sed immensa clementiae tuae largitate... tribuisti, 743 ; et ubi nulla suppetunt suffragia meritorum, tuis nobis succurre praesidiis, 819 ; qui abundantia pietatis tuae, et merita... excedis et vota, 770; or to the intercession of the saints: ut quod nostris meritis non valemus, ejus patrocinio assequamur, 651 .

The viewpoint is entirely different when there is reference to the merits of the saints. Meritum is sometimes the name for the recompense of the blessed. Of St. Gregory the collect says: Deus, qui beatum Gregorium Pontificem Sanctorum tuorum meritis coaequasti, 290. On the feast of All Saints we "venerate": omnium Sanctorum tuorum merita sub una... celebritate, 792. The collect for Ss. Philip and James has: ut quorum gaudemus meritis, instruamur exemplis, 398; and the secret of the Mass, Statuit, puts it simply: ut, dum eorum merita recolimus, patrocinia sentiamus, 1036. In all of these meritum is regarded as "the state of deserving well" without any reference to inadequacy. Sometimes there is reference to these merits as having intercessory power before God. This is cast in a sort of legal formula: suffragantibus meritis, 17, or intercedentibus meritis, 442, 540. The hendiadys: Beati Georgii... meritis et intercessione laetificas, 401, may be considered to fall under this heading also'. The merits of the saints are invoked simply for help in general: ut amborum meritis, aeternitatis gloriam consequamur, 212; eorum semper meritis adjuvemur, 339; ejus nos tribue meritis adjuvari, 402; meritis ipsius protegamur et precibus, 852; beati Marcelli... meritis adjuvemur, 886; quae (salvatio) cum beatorum Martyrum... meritis imploratur, 1066; Sanctorum Martyrum... merita prosequantur, 1054; or sometimes to render the gifts or the "service" acceptable: Munera... beatae Mariae Magdalenae gloriosa merita tibi reddant accepta, 697; ut cujus honore solemniter exhibetur, ejus meritis efficiatur acceptum, 1015. That meritum included the idea of the law of compensation, even when the accent was placed upon its intercessory value, can be seen in the balanced phrases of the secret for the feast of Ss. Nabor and Felix', where we ask that the munera be rendered "pleasing" through the intercession of the martyrs and that they become "worthy" (digna) by reason of their merits: munera... fiant grata suffragiis: et digna perficiantur et meritis, 700 .

1 It is true that meritis may be interpreted as the heavenly reward regarded from the saints' point of view and not considered as an intercessory power. However, the interpretation that the hendiadys is substituted for intercedentibus meritis seems more suitable to us.

2 This prayer is first found for the feast of Ss. Peter and Paul in the Veronense, Mohleerg, 281. 
Merita was used as early as the sixth century by metonomy for the relics of the saints ${ }^{1}$. That seems to be the only plausible interpretation for merita in the secret of the Mass of St. Nicomedes: Adesto... populo tuo; ut beati Nicomedis Martyris tui merita praeclara suscipiens, ad impetrandam misericordiam tuam semper ejus patrociniis adjuvetur, 25; since we are not able to receive anyone else's merits.

There are, finally, a few instances in which this noun is used with almost no notion of reward included. Sometimes it stands for good works: et merito et numero populus... augeatur, 166; ut christiana plebis... credulitatis suae meritis augeatur, 757 . Sometimes it refers to gift or dignity: quibus fidei christianae meritum contulisti dones et praemium 620; cui sacerdotale donasti meritum, dones et praemium, 1119, 1120; Deus, qui et justis praemia meritorum... praebes, $338^{2}$.

MUNIRE; SEC MILITARY TERMS, p. 175.

MUNUS, official service, ritual act, function, gift.

Though munus meant in profane Latin "the performance of a religious, as well as of a civil public service", it was in the first place a legal, not a religious term ${ }^{3}$.

A very prolific word in the orations, it deserves careful investigation; for it displays quite a nuanced character. More than threefourths of the 111 instances of its appearance are in secret prayers orationes super oblata. Hence its most obvious translation would be "gift, offering". And such is indeed at times its meaning; viz., the material gifts destined for the sacrifice: Intende... munera altaribus tuis... proposita, 650; Domine... qui in his potius creaturis, quas ad fragilitatis nostrae subsidium condidisti, tuo quoque nomini munera jussisti dicanda constitui, 487; Tua... muneribus altaria cumulamus, 1143 . See also $383,439,625$. Verbs indicating the act of bringing, such as offerre: $530,554,586,699,700$, 703, 707, 713, 739, 1111, 1160; deferre: 74, 119, 514, 701, 919, 980, 984, $1109,1110,1127$, and the like, lay stress on the interpretation of munus as "gift". Again, such phrases as: Suscipe munera: 688, 711, 726, 729, $1107,1108,1109,1110,1111,1116,1123,1125,1126,1127$; and munera oblata: $17,687,689,691,692,702,705,723,726,729,1064$; or

1 Cf. J. Braun, op. cit., p. 623 f., who quotes an inscription of the 6th century, in which was mentioned that a certain Archbishop Maximinian had buried in the Stephanuskirche the merita apostolorum et martyrum.

2 Meritorum is here interpreted as the objective genitive - "the reward for their good deeds".

- Cf. Antibarbatus, II, p. 105; Heumann-Seckel, p. 356; Mohruann, VC 4, 1950, p. 9, note 16; B. Kỉblek, art. munus, Pauly-Wissowa XVI, 1, p. $644 \mathrm{ff}$. 
oblatis placare muneribus: $730,731,732,733$ seem, at first sight, to refer simply to the gifts presented by the faithful. The whole "service" is also regarded as a gift to God in: Respice... nostram propitius servitutem, ut quod offerimus, sit munus acceptum, 981; and in: Praesens sacrificium... quod tibi pro delictis nostris offerimus, sit tibi munus acceptum, 831 .

However, it is very striking that in secret prayers, munus is used in contexts such as one would expect to find after the Communion rite. The postcommunion for St. Callistus is a case in point: $u$ t reatus nostros munera sacrata purificent, et recte vivendi nobis operentur effectum, 948. Similar ideas appear in the following secrets: ut munera, quae deferimus... et medelam operentur et gloriam, 514; Haec munera... quae oculis tuae majestatis offerimus, salutaria nobis esse concede, 586; Munera nos... oblata purificent, 691 ; Munera, quae tibi... deferimus... nobis proficiant ad salutem, 701. Surely, the material gifts themselves could not produce the effects mentioned. One explanation for the use of such terminology is the fact that the bringing of gifts was in the eyes of the faithful most intimately united to the Eucharistic act of offering. One saw in advance, as it were, the Eucharistic (consecrated) gifts in the natural bread and wine'. Or as Jungmann expresses it: "Zuweilen tritt für einen Augenblick das ganze Gefüge von Opfergeschenken und Opfersymbolik in den Gesichtskreis, wie in der grossartigen Secreta am Pfingstmontag": Propitius haec dona sanctifica: et hostiae spiritalis oblatione suscepta, nosmetipsos tibi perfice munus aeternum, $907^{2}$.

There may be an even more plausible explanation. It was Odo Casel who demonstrated that munus means not only the gifts presented to God at the Offertory and returned deified to the faithful at the Communion, but that it refers more especially to the rite itself which is performed with and over the gifts ${ }^{3}$. Enlarging on this interpretation, H. Frank has shown from examples drawn from the works of St. Ambrose, that munus means, in Christian Latin, "dutiful service" or "official public function"4. From the orations it is clear that the gifts themselves form an essential element of the rite, and that it is impossible to separate the one from the other. Who could say, for example, that munus in a prayer such as: Concede... ut oculis tuae majestatis munus oblatum, et gratiam nobis piae devotionis obtineat, 132, means "gift" rather than "rite", or vice versa? The two concepts form part of a single whole. The same may be said of such a prayer as: Suscipe... munera pro

1 Cf. Herz, op. cit., p. 253.

${ }^{2}$ G. Jungmann, Missarum Sollemnia $a^{5}$, II, p. 119.

3 Odo Casel, Aeitoveria-munus, Oriens Christianus, 3, 7, 1932, p. 289 ff.

- Cf. H. Frank, Aeitovgola-munus, JLW 13, 1935, p. 181 ff. 
tuorum commemoratione sanctorum: ut, sicut illos passio gloriosos effecit; ita nos devotio reddat innocuos, 1107, especially since devotio, which here means "the cultic service or rite"1, is juxtaposed to munera, even as commemoratione is set over against passio. To give two other striking examples: Oblatis... placere muneribus, 731 ; Munera nos... oblata purificent, 691 .

There are some instances, however, where the accent seems definitely to be placed more heavily upon the sacred action than on the gifts. The secret of Ash Wednesday is a case in point: Fac nos... his muneribus offerendis convenienter aptari: quibus ipsius venerabilis sacramenti celebramus exordium, 554. It is not by the gifts that we begin officially the Season of Lent, but by the whole liturgical celebration. Again, there are times when munus is synonymous with servitus, and this emphasizes the ritual content of the word: Munus quod tibi... nostrae servitutis offerimus, $713^{2}$. The use of sacrificii as a genitivus inhaerentiae also brings out the ritual character of the word munus in: ut hujus sacrificii munus oblatum, fragilitatem nostram ab omni malo purget semper, et muniat, 130; and in: praesta nobis... hujus munere sacramenti purificatum tibi pectus offerre, 1169. In the prayer over the people: Da... populis christianis: et quae profitentur agnoscere, et caeleste munus diligere quod frequentant, 182, munus also stands for the rite, since frequentare means, not "to attend in great numbers" nor "to frequent", but even as does celebrare "to perform a sacred rite"3. The clearest example of munus = rite is the prayer introduced into the Appendix of the Gregorianum, as the postcommunion of the Missa pro remissione peccatorum ${ }^{4}$. Alcuin borrowed this prayer, no doubt, from the Gel. Vetus or from one of the Gelasiana Saeculi VIII ${ }^{i}$. Its earliest appearance is in the Gel. Vetus ${ }^{5}$, where it is found among the Orationes paschales vespertinales. Its form there is: Praesta nobis, omnipotens Deus: ut percipientes paschali munere veniam peccatorum, deinceps peccata vitemus; where there is no question of munus meaning anything other than "paschal celebration". In Alcuin's version, the substitution of hoc for paschali and the use of the prayer as a postcommunion, prompt the interpretation of munus as "gift of God - the fruit of the Sacrifice"6. Munus occurs once also as "sacerdotal duties or honors": Praesta... ut anima famuli

Cf. p. $97 \mathrm{f}$.

2 servitutis is a genitive of definition.

Cf. p. 102; Diezinger, op. cit., p. 142.

- Cf. H. A. Wrlson, The Gregorian Sacramentary under Charles the Great, London 1915, p. 197.

B Mohlberg, 521.

- However, see the treatment of munus in pastcommunions below. 
tui, $\mathcal{N}$. Sacerdotis, quem, in hoc saeculo commorantem, sacris muneribus decorasti; in caelesti sede gloriosa semper exsultet, 844.

That brings us to the second place where munus is found in the ORATIONs; viz., in postcommunions. Here, too, there is sometimes a wavering between its meaning as "rite" and as "gift". In: Mysteria nos... sumpta purificent: et suo munere tueantur, 7151; and et quod tempore nostrae mortalitatis exsequimur, immortalitatis munere consequamur, 964, we may say that munus means "gratuitous gift"; while in: tu reatus nostros munera sacrata (some MSS have sacra) ${ }^{2}$ purificent, 948 ; and Ut sacris... reddamur digni muneribus: fac nos tuis... semper obedire mandatis, 1175 , one should translate munus as "official rite".

What is most conspicuous about the use of munus in postcommunions is that it usually stands for nourishment. By it we are abundantly fed: Divini muneris largitate satiati, 477; Sacro munere or salutaris tui munere satiati, 1022, 1026; Satiasti familiam tuam muneribus sacris, 1060; or again: Repleti... muneribus sacris, 974, 975; or Tantis repleti muneribus, 1136 . It is the nutriment by which the supernatural life is maintained and increased : caelestis vitae munere vegetati, 107; Gratias tibi referimus... sacro munere vegetati, 576 ; sacramenti munere vegetati, 716 ; Redemptionis nostrae munere vegetati, 959 ; ut divinis vegetati sacramentis, ad eorum promissa capien$d a$, tuo munere praeparemur, $63^{3}$. It revivifies when the spiritual vitality is low: Quos caelesti recreas munere, perpetuo... comitare praesidio, 955; Refecti participatione muneris sacri, 963 . It is a satisfying delicacy which allays the attracttion of earthly pleasures: munera tua nos... a delectationibus terrenis expediant, 709. It is a gift in which we may always glory: ut vivificationis gratiam consequentes, in tuo semper munere gloriemur, 840. Even here munus is seen as nourishment and we glory, as Brou so well says: "sans

1 The same expression: in nobis tua munera tuearis, 195, is used in the secret of the Mass of St. Thomas, where munera may, by metonymy, mean the "effects of the sacred rite" or simply "grace". The modifier tua lends weight to the latter interpretation.

2 It would seem that sacra is the better reading. It is found in the Angouleme, and the Paduense; while sacrata is read in the Sacramentary of Prague and the St. Gallen. Sacra may be considered the lectio difficilior, since in a postcommunion one would be inclined to think of the munera as sacrata, "consecrated". Furthermore, we have noticed that the Sacramentary of Prague has many orthographical errors.

3 We consider munere here to be synonymous with sacramentis, i.e. the ritual reception of the sacramental food; for it is precisely this mumus - "Holy Communion" - which is the preparation for the promises made by Christ: Qui manducat meam camem, et bibit meum sanguinem, habet vitam aeternam: et ego resuscitabo eum in novissimo die, Jn. 6, 54. The interpretation of munere as "faveur, grâce" is also possible, but is, we think, farther from the general tone of the postcommunion; $\mathrm{cf}$. Brou, Les oraisons des dimanches, p. 34. 
aucun doute, dans le fait de la recevoir corporellement, puisqu'il est destiné à notre nourriture spirituelle"'. All these constructions with munus point to the fact that the Eucharist is food. Could there be found anywhere a more vivid expression of the doctrine that the consecrated species, the munera, are the sacramental sign of the Body and Blood of Christ, to be eaten for the life of the soul?

But there is even more to be noted about this use of munus in postcommunions. The word has something of "rite" in it, as can be seen from the words with which it is used. Note that munus is described as sacrum, 1022, 1060, 974, 975, 576; or as caeleste, 955; or tantum, 1136 - all indicating a certain sacral element. It is called the caelestis vitae munus, 107; and even more strikingly the sacramenti munus, 719. Again, the addition of the word participatio, 963, clearly points to the ritual character of the word. Thus Holy Gommunion is not only a personal reception of Christ, but it is a ritual eating of His Body and Blood - an act which is a constituent part of an official public service.

There remain to be considered the few instances in which munus occurs simply in the sense of "grace". Here its origin is not in the legal language, but in the more general speech, where it meant "gift". It was one of the native Latin terms which, along with donum, donatio, and gratia gradually replaced charisma to express the inner spiritual concept of "grace"2. Martyrdom is seen as the result of God's free gift of grace: Deus, qui sanctis tuis Abdon et Sennen ad hanc gloriam veniendi copiosum munus gratiae contulisti, 442, as the genitivus inhaerentiae (munus gratiae) clearly indicates. The same is said of the service of God in general: ut, gratiae tuae munere, ab omnibus tibi gradibus fideliter serviatur, 758; Deus... de cujus munere venit, ut tibi a fidelibus tuis digne et laudabiliter serviatur, 742. There is the petition for the direction of the church by grace: tuo semper munere gubernetur, $521^{3}$; and for the granting of the help of grace to all who trust in God: ut omnibus in te sperantibus auxilii tui munus ostende, 755 . Even the proper reception of the dona caelestia is seen to be possible only by the grace of God: ut quae sedula servitute donante te gerimus, dignis sensibus tuo munere capiamus, 1076. The parellelism between munere and donante leaves no doubt that the former refers here to "grace" as a free gift of God and not to the sacramental sign of Holy Communion. In the secret for the Vigil of Christmas: ut, sicut adoranda Filii tui natalitia

1 Cf. Brov, Les oraisons dominicales, p. 117. He adds characteristically that the glorying of a Christian consists in giving himself over freely and without reserve to all the exigencies of that divine nourishment.

Cf. Mohrmann, Etudes, I', p. 117.

- Cf. Brou, Les oraisons des dimanches, p. 79. 
praevenimus, sic ejus munera capiamus sempiterna gaudentes, 177, the modifier, ejus, almost necessitates our translating munera by "grace".

NEXUs, physical bond, legal obligation'.

This noun occurs but twice in the ORATIONs - both times in the identical phrase: a peccatorum nexibus liberemur, 7; 280. The collect for the feast of the Chair of Saint Peter reads thus: Deus, qui beato Petro Apostolo tuo, collatis clavibus regni caelestis, ligandi atque solvendi pontificium tradidisti: concede; ut, intercessionis ejus auxilio, a peccatorum nostrorum nexibus liberemur, 280. The reference in the relative clause to Peter's power of binding and loosing leads to the conclusion that nexus is to be translated by "bonds" or "bondage" - in a metaphorical sense, of course. The interpretation of peccatorum as a genitive of definition eliminates the need of seeking behind nexus any other than the classical meaning. The same explanation renders the collect for Dom. XXIII post Pent. less of a puzzle also ${ }^{2}$ : Absolve... tuorum delicta populorum: $e t^{3}$ a peccatorum nexibus, quae pro nostra fragilitate contraximus, tua benignitate liberemur, 7. The second member of the prayer simply says: "and in your mercy may we be freed from the shackles of sins, which we have by reason of our weakness committed". Sin is in fact frequently regarded as bondage: it is referred to as vinculum at least eight times in the ORATIONs ${ }^{4}$. Hence it seems unnecessary to seek the Late Latin meaning of "entanglements" or "effects" in the word nexus as some modern authors $\mathrm{do}^{5}$.

PATrocinium, defense, protection.

This noun in Classical Latin was frequently applied to the forensic defense which an advocate offered to an accused person ${ }^{6}$. In the ORATIONs it retains some of its legal connotation in its application to

1 Cf. Antibarbarus, II, p. 132; HeumanN-Seckel, p. 364.

- Cf. Brov, Les oraisons des dimanches, p. 115.

all the sources before 1570 read et instead of $u t$. This must, we think, be considered the correct reading. The combination of an imperative (absolve) and an optative subjunctive (liberemur) joined by et is not unknown in the early prayers (cf. for example, 39, 59). Nor is it unusual for these prayers to repeat the same idea in other words (cf. 56, 541). Both of these phonomena - paratactic construction (e.g. Audi Iuppiter, audite fines, audiat Fas! Liv. 1, 32, 6) and pleonasm (prohibesses, defendas averruncesque, Cato, De agr. 141, 7) - are found in early pagan Roman prayer formulae.

4 No. 5, 6, 302, 472, 585, 615, 883, 892.

- Cf. Haessly, op. cit., p. 120 and 161; C. G. Martindale, Prayers of the Missal, New York, N.Y. 1938, p. 82. Both these authors, as well as Brou, interpret nexibus as the entanglements, or the effects that are the result of sin, instead of the sin itself. - Cf. Heumann-Seckel, p. 410; Forcellini-de Vit, IV, p. 533. 
the saints as our intermediaries with God, as its use in connection with other legal terms indicates: ut ejus semper et patrociniis sublevemur, 162; Intercessio nos... beati $\mathcal{N}$. ... commendet: ut quod nostris meritis non valemus, ejus patrocinio assequamur, 651; ad impetrandam misericordiam tuam semper ejus patrociniis adjuvetur, 25. The image of the saint as an advocate in the presence of God is vivid in: Da...ut, qui beatae... Martyris tuae solemnia colimus: ejus apud te patrocinia sentiamus, 189, 787. As is the case with so many other words, this noun, too, loses in liturgical Latin much of the preciseness of its original meaning, and becomes a general term for help, in which the element of pleading is all but lost: dum eorum merita recolimus, patrocinia sentiamus, 1036; cujus nos donasti patrocinio gubernari, 1043; beatae Mariae semper Virginis patrociniis nos ubique protegi, 1089; Magdalenae patrociniis eruamur, 1093; cujus nos confidimus patrocinio liberari, $1109 ;$ Apostolorum... patrocinio confidentem, 917. A vestige of the notion of pleading, however, is still felt in: Exaudi... populum tuum cum Sanctorum tuonum patrocinio supplicantem, 527; and in: quae tibi tuo grata sunt instituto, gratiora fant patrocinio supplicantis, 57.

POENA, punishment, damnation.

A very old legal term, found already in the Law of the Twelve Tables, poena referred to punishment for both public and civil crimes ${ }^{1}$, but it had also a very general meaning in the common language. In the orations it refers to punishment for sins - sometimes in a very general sense: et a poenis quas pro his meremur eripias, 648 ; per originalis peccati poenam, 434 ; sometimes with the meaning of eternal damnation ${ }^{2}$ : non poenas inferni sustineat, sed gaudia aeterna possideat, 208 . In view of the strong antipathy felt against Judas we may assume that in: Deus, a quo et Judas reatus sui poenam... sumpsit, 200, it also means eternal punishment. It may quite well have reference to the practice of public penance imposed on sinners, in the clause: ut non amplius eis noceat conscientiae reatus ad poenam, 756; for this prayer occurs in the Gel. Vetus under the title: Orationes in quinta feria - Item ad reconciliandum paenitentem $^{3}$. The same expression: reatus ad poenam, occurs in 923 . See reatus below.

1 G. Heumann-Seckel, p. 435.

- Cf. Teeuwen, op. cit., 71 ; Raymond James Kinnavey, The Vocabulary of St. Hilary of Poitiers as Contained in Commentarius in Matthaeum, Liber I Ad Constantium and De Trinitate. A Morphological and Semasiological Study, Washington, D.C. 1935, p. 233.

- Mohlberg, 360 . 
PURGARE; see MEdical TERMS, p. 185.

REATUs, the state of being accused, guilt, $\sin ^{1}$.

Though basically, in legal language this noun means simply the state of being accused, but not yet convicted nor acquitted, it came to be used mostly in malam partem. It retains something of the original content of accusation in: qui conscientiae reatu constringuntur, 922; ut non amplius eis noceat conscientiae reatus ad poenam, 756, where it seems to be very close to the English "guilty conscience". In the postcommunion, Pro vivis et defunctis, reatus is employed as the antonym of intercessio : ut hoc sacramentum non sit nobis reatus ad poenam, sed intercessio salutaris ad veniam, 923. Hence it must, in this context, mean "indictment". In the other instances of its use, it is simply more or less technically "sin" as such. Sometimes it is used in conjunction with other terms of legal origin, as in: a propriis nos reatibus... expediat ${ }^{2}, 158,717$; a cunctis nos reatibus et periculis... absolve, 2; a cunctis reatibus absoluti, 214; Judas reatus sui poenam... sumpsit, 200. In other instances there is no trace of legal setting: ut reatus nostros munera sacrata purificent, 948 ; ut reatus nostri confessio, indulgentiam valeat percipere delictorum, 338.

REMEDIUM; see MEDICAL TERMS, P. $186 \mathrm{f}$.

REus, guilty ${ }^{3}$.

qui ex iniquitate nostra reos nos esse cognoscimus, 32 . This noun occurs only once in the ORATIONs, probably because it did not have a sufficiently solemn character to fit the exalted style of these prayers.

SERviTUs, slavery, service, sacred function".

This classical word for slavery as opposed to libertas, is used twice in the ORATIONS in the tropical sense. Sin is regarded as a bondage from which God alone can deliver us. To be noted is that both times servitus is modified by oetustus, which lends a Pauline color and heightens the urgency of the petition for liberation through the new birth of Christ ${ }^{5}$ : $u t$, qui sub peccati jugo ex vetusta servitute deprimimur; ...nova nativitate liberemur, 139; ut nos Unigeniti tui nova per carnem Nativitas liberet; quos sub peccati jugo vetusta servitus tenet, 131.

Man stands before God not only as a member of His family, but

1 Cf. Heumann-Seckel, p. 517; Forcellan-de Vrt, V, p. 92; Kinnavey, op. cil., p. 30 .

Cf. p. 154.

- Cf. Heumann-Seckel, p. 517.

- Cf. Antibarbants, II, p. 518.

s Cf. vetustas, p. 58. 
also in the relation of a slave before His master. His moral acts are, therefore, rightly viewed as being a "service of God". This purely religious sense of servitus is in line with the semantic development of

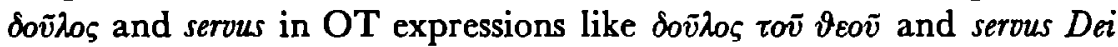
and, then, also servus Christi, which were among the terms used since NT times by the Christians to designate their "brethren"1. Servitus in this moral, religious connotation is found also in the orations. Precisely because living a good moral life is a service of God, it cannot be accomplished without supernatural aid. This fact is accurately emphasized in the postcommunion of Fer. $V$ post Dom. II Quadr., where this servitus is seen as the effect of God's grace: Gratia tua nos... non derelinquat: quae et sacrae nos deditos faciat servituti, 5732. The postcommunion Pro peste animalium regards it as the fruit of the sacred action: Benedictionem tuam, populus fidelis accipiat, qua corpore salvetur, et mente: et congruam tibi exhibeat servitutem, 82; while the collect of the Easter Vigil asks for it as an outcome of the Paschal Mysteries: $u t$ corpore et mente renovati, puram tibi exhibeant seroitutem, 346.

Even when this word evidently stands for "service at the altar", something of the original meaning of servitus remains. This can be seen in the oxymoron, libera servitus in: ut nullis perturbationibus impediti, liberam servitutem tuis semper exhibeamus officiis, 541; and the slight pleonasms in: Debitum tibi... nostrae reddimus servitutis, 195; quod debitae servitutis celebramus officio, 1022. But what is the actual meaning of "service" in these last three cases? Is it the sacred rite as such, or is it the sacerdotal ministry as distinguished from the "service" of the lay people? Brou states: "On sait que, dans les anciens documents liturgiques, le mot seroitus signifie le service proprement sacerdotal, hiérarchique et, par extension, les prêtres eux-mêmes et les ministres de l'autel, pour les distinguer du reste du peuple"3. Because the sense of the secret of Dom. $X I$ post Pent.: Respice... nostram propitius servitutem: ut, quod offerimus, sit tibi munus acceptum, 981, demands it, he goes on to explain that servitus means not so much the "state" as the "act" of the sacerdotal ministers,

1 Cf. Teeuwen, op. cit., p. 125-128; Bartelink, op. cit., p. 102; PÉtré, op. cit., p. $116 \mathrm{ff}$; Lonte, op. cit., p. $78 \mathrm{ff}$. and p. $83 \mathrm{ff}$. has shown how this terminology with servitus has been applied to the life of the monk in the Latin translations of the Vila Antonii.

Since the official practices of Lent were regarded as a liturgical function, servitus could be here interpreted in the ritual sense. The moral aspect would, however, not be absent.

- Cf. Brou, Les oraisons des dimanches, p. 62, p. 118; Sacris Enudiri 2, 1949, p. 183 ff.; P. Battrpol, Lefons sur la messe, Paris 19277, p. 250 ff.; B. Botre, Le Canon de la messe romaine. Edition critique, introduction et notes, Louvain 1935 , p. $58 \mathrm{f}$. 
the act by which they officially offer to God the public worship in the name of the people whose intermediaries they are. Thus it means the sacred function itself. It is to be interpreted also in this same sense in: quae sedula servitute donante te gerimus, 1076; Grata tibi sit... nostrae servitutis oblatio, 572; Munus, quod tibi... nostrae servitutis offerimus, 713 . The secret: Pro nostrae servitutis augmento sacrificium tibi laudis offerimus: $u t$, quod immeritis contulisti, propitius exsequaris, 893, is somewhat difficult to interpret with surety. Adhering to his argument quoted above, which argument he sees strengthened by the phrase: ut, quod... exsequaris, Brou interprets the phrase: Pro nostrae servitutis augmento, as a petition for an increase of "zèle proprement sacerdotal et ministériel"1. Servitus would thus be used, by metonymy, for priestly zeal. Such an interpretation is quite plausible; but it seems strange that a secret for a Sunday should have as its object a petition exclusively for the clergy. Hence it would seem perhaps better to see in servitus the Biblical moral "service of God", since this, too, as we have demonstrated above, is viewed in the ORATIONS as a gift of God².

SUFFRAGIUM, support, intercession.

According to Ernout-Meillet ${ }^{3}$ this noun is derived from suffragari, "to vote for", "to give approbation or support to". In the time of the Republic it referred generally to an individual's vote for a magistrate. However, under the Empire, it came to be used for the intercession of an influential person before the emperor or other higher rulers, especially to help someone secure an office. The practice of asking God for anything through the mediation of the saints, undoubtedly derived from the earlier custom of asking any of the faithful departed, and particularly the martyrs, to intercede for those on earth ${ }^{4}$. In the ORATIONS, the martyrs, other saints and even St. Michael are considered as being influential with God. Their support is sought as a means of rendering the sacrifice pleasing to God: Munera plebis tuae... sanctorum Martyrum... fiant grata suffragiis, 700 ; ut easdem (hostias), angelico pro nobis interveniente suffragio et placatus accipias, 623 ; or simply that we may be helped by their prayers: quorum suffragiis nitimur, 56 ; ut suffragiis beati Thomae Apostoli, in nobis tua munera tuearis, 195; Beatae Mariae Magdalenae... suffragiis adjuvemur, 68; et intercessionis percipiamus suffragia, 915. One

1 Cf. Brou, Les oraisons des dimanches, p. 118.

Cf. servire, p. 56; note how well the secret for St. Luke expresses this concept: Donis caelestibus da nobis... libera tibi mente seroire, 514 .

Op. cit., p. 663; cf. also B. Küglen, art. suffragium, Pauly-Wissowa, IV, 1, p. 654 ff.

- Cf. p. $157 \mathrm{f}$. 
might almost say that there is a kind of holy bargaining. The Church on earth celebrates a feast in honor of a saint, and then expects his "support" in return: Fac nos,... sanctorum Martyrum tuorum Primi et Feliciani semper festa sectari: quorum suffragiis protectionis tuae dona sentiamus; 555; Fraterna nos... Martyrum tuorum corona laetificet: quae et fidei nostrae praebeat incrementa virtutum; et multiplici nos suffragio consoletur, 570 . See also $658,847,1180$. Finally, there is one instance of suffragium used of the deficiency of our own influence: Placare, ...humilitatis nostrae precibus et hostiis: et ubi nulla suppetunt suffragia meritorum, tuis nobis succurre praesidiis, 819.

SUFFRAGARI, to support, to intercede for.

Here we have another striking example of the phenomenon that verbs do not tend to become technical so soon as do nouns. This verb occurs only twice in the ORATroNs - both times in the familiar ablative absolute construction, which is so frequent in the case of intercedere: beatae Anastasiae martyris tuae suffragantibus meritis, 17 ; nullis suffragantibus meritis, sed immensa clementiae tuae largitate, 743.

SUBLEVARE, to support ${ }^{\mathbf{1}}$.

ut ejus semper et patrocinius sublevemur, $162 ;$ ut... ejus apud te precibus sublevemur, 261. Frequent in Classical Latin especially in its tropical sense of "support", sublevare was also a legal term. The extent of its legal connotation in the above quotations depends on to what extent patrocinium and preces (in the sense of intercessory prayers) still had legal content. It has obviously the very general meaning of "to help" in: ut adventus tui consolationibus subleventur, qui in tua pietate confidunt, 561 .

\section{MILITARY TERMS}

The concept of Christian life as a militia Christi has its origin for the most part with St. Paul, who refers to the christian virtues as arma justitiae ${ }^{2}$, and gives a detailed description of the spiritual enemy and of the supernatural weapons at the Christians' disposal ${ }^{3}$. He calls the apostle and the missionary a miles Christi ${ }^{4}$. Christian life as a whole, beginning with Baptism, was viewed by Early Ghristian writers as a warfare. Every Christian was a miles Christi. The term miles Christi and

1 Cf. Heumann-Seckel, p. 561.

2 Cor. 6, 7; also 10, 3-6.

Eph. 6, 10-18.

4 2 Tim. 2, 3; and 1 Tim. 1, 8; cf. A. von Harnack, Militia Christi, Tübingen 1905, p. 12 ff. 
other military metaphors applied especially to the martyrs ${ }^{1}$; and after the time of the persecutions this whole terminology was applied to ascetics and monks ${ }^{2}$. The orations employ but a limited number of military figures.

ARMA, weapons.

Sactamentis... muniamur acceptis: et... contra omnes nequitias irruentes, armis caelestibus protegamur, 999. Here arma is used in a vivid military metaphor to describe the supernatural (caelestibus) protection against the onrushing forces of wickedness. To be noted is the fact that this is a postcommunion, and the Pauline figure of protective weapons in Eph. 6, 10-16, is alluded to here in order to express the effect of the reception of the Eucharist ${ }^{3}$. In the postcommunion of the Missa pro pace: ut, qui in defensione tua confidimus, nullius hostilitatis arma timeamus, 204, arma refers in the first place to the weapons of war properly so called. However, from the context of the prayer, especially of the relative clause, it can be safely inferred that the nullius hostilitatis arma includes attacks of spiritual, as well as physical enemies.

EXPEDITUS, unincumbered, unhampered 4 .

As a strictly military figure, "freed from impediments", this adjective appears in: Omnipotens et misericors Deus, universa nobis adversantia propitiatus exclude: ut mente et corpore pariter expediti, quae tua sunt, liberis mentibus exsequamur, 751. Its sense is somewhat more general in: Mundet et muniat nos... munus oblatum: et... a cunctis nos reddat et perversitatibus expiatos, et adversitatibus expeditos, 687. In this latter the striving for rime is, no doubt, a contributing cause for its use.

FIRMAMENTUM, a fortified protection.

This noun is found but once in the orations: hoc sactamentum... sit contra omnia mundi pericula firmamentum, 923. Here firmamentum is synonymous with munimentum, in a metaphorical sense, of course. It is used to designate the power of the Eucharist in warding off sin.

IMPUGNARE, to attack.

Populi tui... peccata, quibus impugnatur, expelle, 823. Sin is regarded here as the enemy attacking the people of God.

1 Cf. Hoppendrouwers, op. cit., p. 71 ff., p. 149 ff.; Matti A. Sanno, Semariologische Untersuchungen über die Entstehung der christlichen Latinitat, Helsinki 1940, p. 25, p. 119.

2 Cf. von Harnack, Militia Christi, p. 93 ff.; Lorit, op. cit., p. 102 f.; E. Malone, The Monk and the Martyr. The Monk as the Successor of the Martyr, Washington, D.C. 1950 , p. $91 \mathrm{ff}$.

- Cr. discussion of munire, p. $175 \mathrm{f}$.

- Cf. TLL V, p. $1605 \mathrm{ff}$. 
MILITIA, military service, soldiers'.

Although this term was used rather frequently in Early Christian writings to designate the life of the Christian in general, and especially the sufferings of the martyrs, as a military service ${ }^{2}$, still it occurs only once in the orations: Concede nobis... praesidia militiae christianae sanctis inchoare jejuniis, 117. Here two interpretations are possible. It may be construed as a genitive of definition modifying praesidia; in this case it would mean "military service"s. It may also be considered as an abstract noun used in a concrete and personal sense ${ }^{4}$; and then militia christiana must be translated as "soldiers of Christ".

MUNIMEN, rampart, fortified protection ${ }^{5}$.

The Late Latin word for the more strictly classical munimentum is found three times in the orations. The juxtaposition, which is somewhat forced, shows that munimen is used for stylistic reasons in: Populi tui... peccata, quibus impugnatur expelle: ut semper tibi placitus, et tuo munimine sit securus, 823. Over against the peccata by which the people of God are attacked is visualized a munimen set up by God. That the sacrament is the source of cleansing from sin as well as a protection from new sins is expressed in: Vivificet nos... hujus participatio sancta mysterii: et pariter nobis expiationem tribuat et munimen, 1178. So, too, the sacrosancta mysteria are regarded as a protection of our new life, in the postcommunion for Dom. in Albis: ut sacrosancta mysteria quae pro reparationis nostrae munimine contulisti, 928.

MUNIRE, to fortify, to protect, to strengthen.

Properly, this verb means "to fortify with a wall" and in a transferred sense, "to protect". The notion of protection as a military figure is very vivid in the prayer after the distribution of ashes, where we ask to be protected by the auxiliaries of fasting: ut contra spiritales nequitias pugnaturi, continentiae muniamur auxiliis, 117. Though somewhat less vivid, it is still a military figure in: ut Apostoli tui Jacobi munita praesidiis, et conversatione tibi placeat, et secura tibi mente deserviat, 524 ; ut ejusdem fidei firmitate, ab omnibus semper muniamur adversis, 774 . The mighty power of

1 Cf. von Harnack, Militia Christi, passim; Hoppenarouwers, op. cit., p. 72.

2 E.g., Tert., Ad mart. 3; Cypr., Epist. 56, 2; Comm., Instr. 2, 12, 11.

S Cf. BonNet, op. cit., p. 197.

- Gf. LöfSTEDT, Kommentar, p. 110 ff.; Vermischte Studien zur lateinischen Sprachkunde und Syntax, Lund 1936, p. 211 ff.; Mohrmann, Etudes, I², p. 227 ff.; has demonstrated that this same phenomenon; viz., the use of an abstract mysteria (ministeria) for the personal and concrete ministri, makes the phrase: exultent divina mysteria, of the Exultet quite logical.

- Cf. Antibarbarus, II, p. 105. 
the very ministers of God, the Angels, is invoked as a protection on the feast of the chief of Angels, St. Michael: ut a quibus tibi ministrantibus in caelo semper assistitur, $a b$ his in terra vita nostra muniatur, 387.

Munire as a military figure is used also to designate the effects of the Eucharistic action: Sacramentis... muniamur acceptis: et... contra omnes nequitias irruentes armis caelestibus protegamur, 999; Oblatum tibi... sacrificium vivificet nos semper, et muniat, 734; Haec nos... divini sacramenti perceptio protegat... et muniat, 590 . It is very interesting to note that the combination of mundare, 687, 975; purgare, 130; or purificare, 924, with munire serves to express the idea enunciated by Our Lord in Lk. 11, 21-26; viz., that purification from sin is not enough; there is need also of the protection of the Divine Stronger One, lest the devil return with seven others more wicked than himself, and re-entering the soul, dwell therein. Therefore, the Church prays that the sacramental action may fortify as well as cleanse. And the urgency of the prayer is sometimes enhanced by the alliteration: Mundet et muniat, 687. The postcommunion for Dom. VI post Pent. is a vivid enunciation of the two effects of the Eucharistic action: Repleti sumus... muneribus tuis: tribue ut... eorum et mundemur effectu, et muniamur auxilio, 9751.

In a few instances munire has more of a legal connotation, "to protect by means of intercession": et eorum perpetua supplicatione muniri, 180; ut in cujus haec commemoratione percepimus, ejus muniamur et precibus, 961. See also 315,460 . Sometimes it is difficult to determine whether muniamur is a legal or a military figure, or simply a term purposely left very general and vague so that it might have a broad application: $u t$ ab omnibus adversitatibus muniamur in corpore, et a pravis cogitationibus mundemur in mente, $313^{2}$. No doubt the pun in the juxtaposition of muniamur to mundemur has also played a role in the use of munire here.

PRAESIDIUM, auxiliary forces, support.

Only once does this noun appear in the orations in an evident military figure: Concede nobis... praesidia militiae Christianae sanctis inchoare jejuniis, 117. In this phrase it is used by metonymy - the garrison for the warfare itself. Munita helps to add something of a military tone to praesidiis in: ut Apostoli tui Facobi munita praesidiis, 524.

1 Cf. Brou, Les oraisons des dimanches, p. 38, who suggests that since the postcommunion, 975, appears in the Veronense among the preces diumae cum sensibus necessariis (Mohlaerg, 636), muniamur auxilio may have reference here to a period of war, in which this prayer was composed. This may well be so; however, in view of the use of this verb in other prayers with no such reference, one need not draw that conclusion.

2 Cf. Brou, Les oraisons dominicales, p. 77 f. 
In all other instances, praesidium is used to indicate supernatural help or support in general'. God is Himself called the infirmitatis humanae singulare praesidium, 234. Sometimes this grace is petitioned directly from God: Concede... fragilitati nostrae praesidium, 115. See also 819. More often it is regarded as the fruit of the sacred action: Mysterio tua... tractemus: quibus et praesidium nobis crescat, et gaudium, 716; 902. That praesidium stands for the abiding grace to bring to fruition in our daily life that which is begun in the sacramental action can be determined from the words indicating continuance - comitare, continuum, sempiternis - in the following postcommunions: Quos caelesti recreas munere, perpetuo... comitare praesidio, 955 ; Tribuant nobis... continuum tua sancta praesidium, 1138; Tuorum nos... largitate donorum, et temporalibus attolle praesidiis, et renova sempiternis, 1164.

PUGNARE, to fight.

ut contra spiritales nequitias pugnaturi, continentiae muniamur auxiliis, 117. This clause, obviously inspired by Eph. 6, 122, expresses once again the idea so common in Early Christian writers; viz., that the Christian life in general and the practice of asceticism in particular is a warfare ${ }^{3}$. Fasting is one of the helps to this "fighting".

sUBsIDIUM, military reinforcements, assistance, support.

In only two instances is there evidence that this noun maintains a military connotation in the oratrons. The postcommunion for Dom. I Pass. contains the same concept that we have seen when discussing munire; namely, that the spiritual life is both renewed and protected by the Eucharist: quos tuis mysteriis recreasti, perpetuis defende subsidiis, 33 . Again, we pray that we might be protected through the celebration and reception of the Eucharist: Sumptis redemptionis nostrae muneribus: praesta... eorum nobis celebratione, tuae protectionis contra omnes adversitates subsidium, 1091.

For the rest, the word is used for supernatural help or support in a very general way. Sometimes it stands for the Divine intervention in securing natural gifts so that these may help us to a better service of God, as in the petition for rain: ut praesentibus subsidiis sufficienter adjuti, sempiterna fiducialius appetamus, 229. Or the natural gifts which are a subsidium for the body become, through their being consecrated, also a subsidium for the soul, as the secret in Tempore Famis so admirably puts

1 Cf. Blatse, Dictionnaite, p. 654; Mueller, op. cit., p. 219.

- quoniam non est nobis colluctatio adversus camem et sanguinem, sed... contra spiritualia nequitiae, in caelestibus.

- Cf. militia, p. 175. 
it: Deus, qui humani generis utramque substantiam, praesentium munerum et alimento vegetas, et renovas sacramento: tribue, quaesumus; ut eorum et corporibus nostris subsidium non desil, et mentibus, 353. Finally, there is a request for divine subsidium for human weakness through the power of the Eucharistic action, which is itself called subsidium: Imploramus... ut haec divina subsidia, a vitiis expiatos, ad festa ventura nos praeparent, 639; Sumptis... salutis nostrae subsidiis, 1089. See also 814, 1063, 1082.

vexillum, cavalry banner, the Cross.

7.C.D.N. corpore et sanguine saginandi, per quem Crucis est sanctificatum vexillum, 657; qui Unigeniti Filli tui pretioso sanguine vivificae Crucis vexillum sanctificare voluisti, 454 . The Cross was already in Early Christian literature compared to the military standards ${ }^{1}$ because of the cross-form of these standards ${ }^{2}$. The figure was a favorite one among the poets, e.g. Prud., Cath., 9, 80; Apoth., 448; Fortunatus, Vexilla Regis. To be noted is the fact that in both instances there is mention of the standard being sanctified by the Blood of Christ.

\section{MEDICAL TERMS}

The notion that physical sickness is a consequence of sin is of Biblical origin. This concept is frequently expressed in the OT, especially in the Book of Job. That it was firmly fixed also in the minds of the Jews of Our Lord's time is evidenced by the account in Jn. 9, $1 \mathrm{ff}$., where the disciples asked Jesus: "Rabbi, who hath sinned, this man or his parents, that he should be born blind?" Then, too, sin was referred to as sickness in a metaphorical sense. Jesus said on one occasion: "Those who are well have no need of a physician, but those who are ill. Go, then, and learn the meaning of the expression: "I desire mercy and not sacrifice. For I have come to call not the just, but the sinners"3. In both senses Jesus showed Himself to be the true $\sigma \omega \tau \eta \dot{ }$, for He healed all manner of bodily sickness, and he forgave sins as well.

The Late Antique world was, in its turn, also very strongly under the influence of its powerful $\vartheta \varepsilon \dot{s} \varsigma \omega \tau \eta \dot{\jmath} \varrho$, Asclepius, whose cult was spread throughout the entire Roman Empire by the first centuries of our era. How strong the influence of this cult was, and how it affected the works even of Christian authors can be seen in the writings of the apologists from Justin down to Arnobius4. The philosophers, too, were fond of

1 Tert., Apol. 16, 8; cf. Blasse, Dictionnaire, p. 845.

' Cf. Chr. Mohrmann, Tetullianus' Apologeticum en andere geschriften uit Tertullianus' voor-Montanistischen tijd, Utrecht 1951, p. 51, note 5.

Mt. 9, 12; cf. Mk. 2, 17; Lk. 5, 3.

- F. J. Dölaer, Antike und Christentum 6, 1950, p. 241 ff. 
using medical terms in an applied sense to designate moral deficiencies. The Stoics, in particular, had developed a complex system of moral, as well as physical, philosophy in medical terms ${ }^{1}$. Finally, many of the Early Christian writers, in addition to the apologists, were wont to express Christian doctrine - especially the effects of grace - in medical terminology2.

It is not surprising, then, that we should find medical terms also in the ORATIONS.

\section{ABSTINERE, to refrain from eatings.}

As a medical term, abstinere means "to refrain from eating as a curative measure", or to put it more specifically, "to refrain from eating in order to be in a condition conducive to the effective functioning of a given medical remedy"; as Celsus says: Pridie abstinere debet aeger ut aptus tali curationi sit, Art. 2, 12,2. In the orations this medical connotation is also included in the meaning of this verb; but the cure sought is of the moral order. The use of this verb is expressive of the Christian's realization of the close interrelation of body and soul, and hence the abstaining from physical food is regarded as a prerequisite for, or at least the correlative of refraining from sins, as one of the collects of $F e r$. IV Quat. Temp. Sept. has it so well: ut, dum a cibis corporalibus se abstinet, a vitiis quoque mente jejunet, 843 ; or that of Fer. VI post Dom. III Quadr.: $u t$, sicut ab alimentis abstinemus in corpore; ita a vitiis jejunemus in mente, 656. That the fast of Lent is considered as having a medicinal purpose is further emphasized by the addition of the adjective noxius in the following: ut, sicut ab escis carnalibus abstinemus; ita sensus quoque nostros a noxiis retrahamus excessibus, 146; and, et quos ab escis carnalibus praecipis abstinere, a noxiius quoque vitiis cessare concede, 827 . It is curious that abstinere is used almost exclusively of bodily food in the ORATIONs ${ }^{4}$. In addition to the instances quoted above, there is still ab alimentis, 857 . It is used absolutely in: ut jejunando, tua gratia satiemur; et abstinendo, cunctis efficiamur hostibus fortiores, 174, but it is clear from the context that there is reference to the fasting from physical food. Only once is

1 M. J. Cortìs, Séneque et la médecine stotcienne, REL 36, 1958, p. 45 f.; M. SPANNEUT, Le Stoicisme des Pères de l'Église, Paris 1957, p. $197 \mathrm{ff}$.

2 E.g., Ignatius of Antioch, ad Eph. 20, 2. See other examples cited by A. von Harnack, Mission und Ausbreitung des Christentums, I, Leipzig 1915, p. 120 ff.; Medicinisches aus der ältesten Kirchengeschichte, Leipzig 1892, p. 125 ff.; K. SchNEmER, Geistesgeschichte des antiken Christentums, (I-II, München 1954), I, p. 722 ff.; EIJKENвоом, op. cit., p. 16 ff. esp. 22, 35 ff., 62.

3f. TLL I, p. 193 ff.; Antibarbarus, I, p. 24; LontE, op. cit., p. 69, 90, 100.

Cf. p. 9. 
this verb employed in a tropical sense: a noxiis quoque vitiis abstinentes, 838.

ABSTINENTIA, fasting from food.

As the nomen actionis of abstinere, this noun is an exception to the general rule that nouns sooner become technical terms than do verbs, for it occurs only once in the ORATIONs: ut, qui per abstinentiam macerantur in corpore, per fructum boni operis reficiantur in mente, 468.

CURARE, to cure'.

From the general meaning of "to care for with diligence", the signification of this verb narrowed to indicate care of the body specifically, and finally it became a technical medical term, "to cure". As was the case with many other medical terms, this latter sense was also transferred to the moral order, especially by the Stoics, to mean corrigere (cf. Seneca, Dial. 3.6.3). It is in a tropical sense that it occurs in the orations. Once it has a moral connotation as the effect which fasting is intended to have upon the "whole man": jejunium, quod animabus corporibusque curandis salubriter institutum est, 28. Twice - both times in postcommunions -its meaning lies much deeper than the moral plane, for it refers to the supernatural healing power which is the inner effect of the sacramental action: Sanctificationibus tuis... et vitia nostra curentur, et remedia nobis aeterna proveniant, 1045: and, ut per haec sacramenta quae sumpsimus, quidquid in nostra mente vitiosum est, ipsorum medicationis dono curetur, 121.

EXPEDIRE; See LEGAL TERMS, p. 154.

EXPURGARE, to cleanse, to free from guilt ${ }^{2}$.

From its basic meaning, "to cleanse from spots', this term came to be technical in the legal, agricultural and medical professions. There can be no doubt of its medical sense in: caelestem nobis praebeant haec mysteria, ...medicinam: et vitia nostri cordis expurgent, 85. However, its meaning is very general in: Adsit nobis... virtus Sp. Sancti : quae et corda nostra clementer expurget, 44, and in: Tua nos misericordia... et ab omni subreptione vetustatis expurget, 1149. It is to be noted that purgare is more technical than expurgare in this context of cleansing out the "old leaven of $\sin ^{\prime \prime}$.

1 Cf. TLL IV, p. 1503 f.; EIJKenвoom, op. cit., p. 88, 103, 122.

af. TLL V, p. 1815 f.

- Cf. purgare, p. 185. 
INFIRMITAS, human weakness in relation to one's moral duties.

In Classical Latin infirmitas meant "weakness, or general indisposition" rather than sickness as such. By the time of Pliny (Epist., 10.6. 1), especially in the colloquial speech, it came to be used for physical illness as well". It was used by Cic., Liv., Quint. in the sense of "human condition", especially in a moral sense ${ }^{2}$. In Ghristian authors it is frequently used of the tendency to sin, which is the plight of fallen man, as St. Augustine puts it: Baptismate deleta est iniquitas, sed manet infirmitas, Sermo 155,9,9. In the orATIONs it occurs neither in the medical nor in the special Christian sense of concupiscence, but rather is it used of man's inability or too-short-coming in the face of his duties to God: qui infirmitatis nostrae conscii, de tua virtute confidimus, 175. By reason of this infirmitas man is helpless: qui in tot adversis ex nostra infirmitate deficimus, 192; Deus, qui nos conspicis ex nostra infirmitate deficere, 404; sine te nihil potest mortalis infirmitas, 230. To support it are invoked: the virtus, 175, and the dextera Majestatis, 764 of God; the passio of Christ, 192; the exempla, 404, and intercessio, 649, of the martyrs; and finally, auxilium, 1083 , the inner effect of the sacred action.

The postcommunion of the Votive Mass for the Sick deserves special mention: Deus, infirmitatis humanae singulare praesidium: auxilii tui super infirmos famulos tuos ostende virtutem; ut ope misericordiae tuae adjuti, Ecclesiae tuae sanctae incolumes repraesentari mereantur, 234 . The word infirmitas is, no doubt, here used for stylistic reasons; viz., to counterbalance infirmus.

In the prayer for the bride after the Pater Noster, infirmitas probably is intended in the technical Christian sense, as the context of the phrase indicates: muniat infirmitatem suam robore disciplinae, 434 . However, the insinuation that woman is the "weaker sex" undoubtedly played a contributing role here.

JEJUNARE, to fast.

This word, which was a semantic Christianism since Vetus Latina, was also used by medical writers of "refraining from food for reasons of health ${ }^{3}$. The medical connotation is not exceptionally evident in the use of this word in the orations. While abstinere is used for the bodily fast", jejunare is more often used in a moral sense of "refraining from

1 Cf. Antibarbarus, I, p. 674; Eijkenвoom, op. cit., p. 153.

1 G. TLL IV, p. 1432 ff.; KinnaveY, op. cit., p. 167.

- Cf. TLL VII, p. 249; Engels, op. cit., p. 78.

- G. p. 179. 
vices": a vitiis, $656,843,850$; or a culpa, $857^{1}$. The explanation for this is undoubtedly to be sought not so much in the fact that vitium has sometimes a medical sense, as rather in the striving for a striking and balanced expression; e.g., ut, sicut ab alimentis abstinemus in corpore; ita a vitiis jejunemus in mente, 656 . It may be, too, the fact that jejunium was used so often for "the official liturgical period of fasting" that in liturgical texts the verb was not used in the tropical sense.

JEJUNIUM, fasting, especially as the official liturgical act or season.

Like jejunare, the nomen actionis is not so usual in a medical sense ${ }^{2}$ in the orations, but it does occur ${ }^{3}$. It is most clearly expressed in: Deus, qui ad animanum medelam, jejunii devotione castigari corpora praecepisti, 245 and 814 ; less evidently in: Da... nostris effectum jejuniis salutarem, 181, and purificante jejunio, 193. The addition of the adjectives salutaris, 838, and medicinalibus, 1003, to jejunium may indicate that the word jejunium did not immediately call forth a medical picture; however, these additions may be simply stylistic. The case for jejunium in a medical sense is somewhat strengthened by the fact that continentia ${ }^{4}$ (in all four instances of its use in the ORATIONs, $117,536,794,1012$, synonymous to jejunium) is twice used with a medical connotation: et continentiae salutaris propitius nobis dona concede, 536; qui per continentiam salutarem corporibus mederis et mentibus, 794.

Various other aspects of jejunium are also brought out in the ORATrovs. It is a means of expiation for sin: Accepta tibi sint... nostra jejunia : quae et expiando nos tua gratia dignos efficiant, 11 ; a supernatural advan-

1 Cf. Dizzinger, op. cit., p. 60 ff., esp. 65 ff.

2 Cf. TLL. VII, p. 248; LORNE, op. cit., p. 55, 77, 100.

- The fasting practice of Christianity was very early brought into relation with charity. The Shepherd of Hermas gives a complete description of Early Christian fast: "First purify your heart from every evil desire, then eat only bread and water, then compute the quantity of what you would have eaten and give it to the widows and orphans," Sim. 5, 3, 5-8. This idea is reiterated by later writers, e.g., St Augustine: quia ieiunium sine misericordia ei nihil est qui ieiunet, Sermo 207; St. Leo repeats the same idea in his sermons. Cf. Gunltauna, Jeane et charite, p. 66 ff.; S. LyonNET, De ieiunio et abstinentia ut fontibus caritatis, Verbum Domini 30, 1952, p. $92 \mathrm{ff}$. This last author has assembled a goodly number of texts from Patristic sources which are expressive of the Christian attitude toward fasting.

- Forcellini-De VIr, II, p. 392, notes that Val. Max. $(4,3,6$ and 7, 11) uses continentia for abstinentia. Jerome has continentiis ac ieiuniis, Epist. 100, 5 (cf. TLL IV, p. 699). In the works of St. Leo continentia means essentially the virtue of temperance exercised in regard to food and drink especially by fasting (cf. Serma 42,$2 ; 44,2$ ). However, continentia is not the usual term for fasting among Christian authors. This is, no doubt, due to the fact that from an early date it was used in the narrower sense of "continence". Cf. LoRrs, op. cit., p. 90, note I. 
tage: ut nobis jejunium quadragesimale proficiat, $143^{1}$; a means of pardon: et peccatoribus per jejunium veniam praebes, 338: and a restraint: ut, quos jejunia ootiva castigant, ipsa quoque devotio sancta laetificet: ut, terrenis affectibus mitigatis, facilius caelestia capiamus, 873.

The most usual employment of the word is as a terminus technicus to indicate the official liturgical fast of the Church, whether it be the Lenten fast or the fast of the Ember days. Some noteworthy examples are: Inchoata jejunia... benigno favore prosequere, 643 ; Sacrae... observationis jejunia, 989 ; jejuniorum veneranda solemnia, 833 ; ut nobis... tribuis solemne tibi deferre jejunium, 1171. One finds this same meaning in 814, 832, 656, 1040, 1046, 1169; and less clearly in 562 and 837.

LANGUOR, weakness, sickness.

It occurs only once, in the tropical sense of moral illness or sins: animarum nostrarum medere languoribus ut, remissione percepta, in tua semper benedictione laetemur, 900 . It was so used also by Augustine and other Christian writers ${ }^{2}$, though not so frequently.

MEDELA ${ }^{3}$, medicine, cure.

This word, which is found since Ps. Quint., was used to indicate the effect produced by a medicine, as well as the medicine itself. In this latter sense it was used tropically of a remedy for defects of conduct or sins". In the ORATIONs it occurs twice in the sense of "the cure", or even "the state of health", which results from the application of the remedy of fasting: ut tibi grata sint nostra jejunia, et nobis proficiant ad medelam, 814 ; Deus, qui ad animarum medelam, jejunii devotione castigari corpora praecepisti, 245 . The phrase, ad medelam is also applied to the sacramental action: ut... quae (sacramenta) pro illius veneranda gerimus passione nobis proficiant ad medelam, 815; ut paschalibus initiata mysteriis, ad aeternitatis nobis medelam ${ }^{5}$, te operante, proficiant, 1131 . We pray that our gifts may: et medelam nobis operentur, et gloriam, 514, and that: Sacramenti tui... participatio salutaris, et purificationem nobis tribuat, et medelam, 997 . We see, then, that medela means the state of restored health which is produced

1 The Gel. Vetus, MohlBerg, 1170, has corporale here instead of quadragesimale. This forms a nice antithesis to mentes in the following phrase.

- G. Blaise, Dictionnaire, p. 285; Forcellani-de VIT, III, p. 342; EijRenBoom, op. cit., p. 156, 201.

- Spelled also medella, which A. Sourer in Miscellanea Latina, Oxford 1927, p. 281, following Lachmann, considers the correct spelling. Most MSS, including the Veronense, have it so. Cf. TLL VIII, p. 45.

- G. TLL VIII, p. 518.

- Cf. remedium, p. 186 for an explanation of the expression medela aeternitatis. 
by the working of an inner divine power made effective through the sacramental rites.

MEDERI, to apply a remedy to'.

A word properly of the medical profession, mederi came to have also the more general sense of "to bring help to anyone in adverse circumstances". Cicero, for example, uses it of philosophy (Tusc. 2,11). It occurs twice in the ORATIONs in the tropical medical sense: once of the person to whom the remedy of fasting is applied: qui per continentiam salutarem corporibus mederis et mentibus, 794; and the other time of the sickness to be cured: animarum nostrarum medere languoribus, 900 .

MEDicatio, the act of healing, medicine ${ }^{2}$.

This late and rare word was used by Colum., Plin ${ }^{3}$. and Mart. of medicine proper. It was further used by Christian writers in the tropical sense. It occurs in the orations only once to express the inner effect of the sacrament: quidquid in nostra mente vitiosum est, ipsorum medicationis dono curetur, 121.

MEDICINA, medicine ${ }^{4}$.

Used of the science of medicine, and of the healing remedy as such, this word, too, was employed in the tropical sense as "remedy for moral deficiencies". The material in the Thesaurus ${ }^{5}$ shows that it was used frequently by Christian writers with the special connotation of "preventive remedy", or "means of avoiding sin". Eijkenboom" has shown from examples drawn from St. Augustine how apt a word medicina is for grace. It occurs twice in the orations to indicate the inner effect of the sacrament: Caelestem nobis praebeant haec mysteria... medicinam, 85; medicina sacramenti et corporibus nostris prosit, et mentibus, 973. Note that in this latter prayer the sacrament (construed as a genitivus definitious) is itself designated as the medicine. Deus, cui soli competit medicinam praestare post mortem, 210 , is indeed a unique way of expressing belief in purgatory and the possible need of the healing of defects after death.

MEDICINALIS, medicinal? ${ }^{7}$.

This late adjective, probably an example of the fondness for adjec-

1 Cf. TLL VIII, p. 519.

Cf. TLL VIII, p. 535.

- De actu condiendi, 4.

- Cf. TLL VIII, p. $536 \mathrm{ff}$.

- Cf. TLL VIII, p. $540 \mathrm{f}$.

- Cf. Eujкennoom, op. ait., p. $110 \mathrm{ff}$.

' Cf. TLL VIII, p. 542 f. 
tives in -alis characteristic of the colloquial language, is a partial indirect Christianism. For its use in the tropical sense, the Thesaurus lists only Christian authors. In the orations it follows the usual trend of medical terms; viz., to be used in connection with the fasting practice and to indicate the inner effect of the sacred action. Illustrative of the former tendency are: ut dignitas conditionis humanae per immoderantiam sauciata, medicinalis parsimoniae studio reformetur, 855 and 1003. In the postcommunion of the seventh Sunday after Pentecost the inner effect of the sacred action is called medicinalis operatio: Tua nos, Domine, medicinalis operatio, et a nostris perversitatibus clementer expediat, et ad ea quae sunt recta, perducat, 1146.

PURGARE, to cleanse, to cure by purging1.

Basically this word has the general meaning of "cleanse from filth". The term was also a technical medical name for "to cure by the administration of a laxative". The use of both purgare and remedium in the same prayer surely points to a medical figure in: Haec nos communio purget a crimine: et caelestis remedii faciat esse consortes, 588; and in: remediis purgata caelestibus, 703 . In other instances it is more difficult to determine whether the dominant idea is simply "to cleanse", or whether it means specifically "to heal". Since vitium is also sometimes a medical term and since the sinner is frequently referred to as sick, such expressions as purgemur a vitiis, 34, 813; and fragilitatem nostram ab omni malo purget, 130, may be given a medical interpretation.

However, the word was also used to mean "to clear from guilt" in a legal sense and "to cleanse from sin by means of religious rites". It has this meaning in: Haec oblatio... ab omnibus nos purget offensis, 592; and in: His sacrificiis... purgata anima famuli tui... ad indulgentiam et refrigerium sempiternum pervenire mereatur, 608 . Even though the request for "purification" seems to be made to God directly in the secret, Ad repellendas malas cogitationes, still it is evident from the context that the request is made in virtue of the sacred action: Has tibi... offerimus oblationes pro salute nostra: quatenus animas nostras ab immundis cogitationibus purges, 602. Finally, the Biblical figure of "cleansing out the old leaven" (Ex. 12, 21), which St. Paul has applied to the moral duty of the redeemed in 1 Cor. 5.7, has undoubtedly been the inspiration for the expression: Ab omni nos... vetustate purgatos, 4, which appears in the postcommunion of the first Sunday of Lent (1160) and of the Wednesday of Holy Week (4) ${ }^{2}$.

1 Cf. Forcellint-de VIt, IV, p. 1007; Blaise, Dictionnaire, p. 685.

- Cf. expurgare, p. 180. 


\section{REMEDIUM, a remedy. ${ }^{1}$}

Basically this word has a medical signification, especially with the connotation of "antidote" or "preservative". From this it took on the general meaning of "relief or assistance" in any adverse circumstance. It became also a technical term in legal language as "redress, relief"2.

Thus, it is only from the context that we can determine its meaning in the orAtions. We may safely say that the medical idea prevails in a prayer such as: Sanctificationibus tuis... et vitia nostra curentur, et remedia nobis aeterna proveniant, 1045; and Sumpto... unico ac salutari remedio, 1093. In the first collect for Fer. IV Quat. Temp. Sept., God's mercy is regarded as the remedy: Misericordiae tuae remediis... fragilitas nostra subsistat, 684; while in the secret of Missa Defunct. healing power is attributed to the sacrifice: Munera... quae tibi pro anima famuli tui $\mathcal{N}$. offerimus, placatus intende: ut remediis purgata caelestibus, in tua pietate requiescat, 703 . The postcommunion for Missa temp. belli emphasizes the moral element in this tropical sense of remedy: ut tranquillitate pacis tua potestate servata, ad remedia correctionis utamur, 463.

What is most worthy of note is the frequency of such expressions as remedium sempiternum, 952; remedia aeterna, 1045, remedium... perpetuae (aeternae) salutis, 895, 1157, as the effect or the outcome of the Eucharist. The Eucharist was described already by St. Ignatius of Antioch as qáouakoy ảvavarlas. Theodor Scherman ${ }^{3}$ has shown that this was a widely-spread technical medical term designating an ointment which was an alleged panacea against all ills and thus rendered one immortal. To counteract the false pagan theory, Ignatius established that there is only one bread which is the true remedy of immortality; namely, the bread which is the glorified and immortal body of Christ. We have already seen the expression, medela aeternitatis ${ }^{4}$. Remedium sempiternum (or eeternum) has the same meaning. The Eucharist is referred to as the "Heilmittel", restoring the immortality which has been spoiled by sin. Though aeternum and sempiternum seem to indicate that remedium means immortality in the eschatological sense, still it is also a reality in this life. Expressions like temporalis vitae nobis remedia praebeant, et aeternae, 1078 , and praesens... remedium... et futurum, 928, clearly indicate this. Thus, too, caelestis remedii plenitudine gloriemur, 1063, and caelestis remedii

1 Cf. Antibarbarus, II, p. 452; ForcrLlinI-De VrT, V, p. 160; EIJKENBoom, op. cit., p. $88 \mathrm{ff}$.

C. C. Heunann-Seckel, op. cit., p. 505.

- Cr. Theodor Scherman, Zur Erklärung der Stelle Epist. ad Eph. 20, 2 des Ignatius von Antiocheia, ThQ 92, 1910, p. 6 ff.

- G. p. 183. 
faciat esse consortes, 588, point to the Eucharist as the healing power restoring to us the supernatural health and vitality which is essentially the same now as in the life to come.

The following may be construed in a legal sense: $u t$, qui conscientiae reatu constringuntur, caelestis remedii plenitudine glorientur, 922 ; non ad judicium provenire patiaris, quae fidelibus tuis ad remedium providisti, 95. There are some instances where remedium has the very general sense of "help (always supernatural help, of course) in adverse circumstances": Deus, qui solemnitate paschali, mundo remedia contulisti, 448; also 548 and 1137.

It is philologically interesting to note that exactly the same phrase: caelestis remedii plenitudine glorientur, is used in a legal, 922, and a medical, 1063, context. This fact indicates that those who composed these prayers made use of fixed expressions without being conscious any longer of their origin or original connotation.

SALUBRIS, health-bringing.

This word, which was frequent in Classical Latin, occurs only once in the orations. It is used in a pleonastic construction in the prayer for the blessing of ashes - a prayer which, by the way, is redolent with clichés and exaggerated expressions: ut sint remedium salubre, 769.

SALUBRTER, healthfully, for the sake of producing health.

This adverb occurs twice and both times partly, at least, for stylistic reasons. In: jejunium, quod animabus corporibusque salubriter institutum est, 28, it is pleonastic; while in: quae humiliter gerimus, salubriter sentiamus, 971 , it is undoubtedly introduced to rime with humiliter. In this latter instance it is related to the supernatural salus, and has reference to the inner effect of the Eucharistic action as juxtaposed to humiliter, which refers to the external rite'.

\section{SALUs; see Semantic christianisms, p. $55 \mathrm{f}$.}

SALUTARIs, healthful, advantageous, Salvation-bringing.

Though this adjective was frequent in Classical Latin in the sense of "beneficial, advantageous", the medical idea predominated ${ }^{2}$. There are some instances which we may consider as the tropical medical use of salutaris; viz., four examples in connection with the fasting practice: Da... nostris effectum jejuniis salutarem, 181 ; et continentiae salutaris propitius nobis dona concede (This is the collect for Fer. III post Dom. III Quadr. and hence we translate continentiae as "fasting"3), 536; qui per continentiam

1 C. humiliter, p.36.

Cf. Forcellini-de Vit, V, p. 318 f.

G. p. 182, note 4 . 
salutarem corporibus mederis et mentibus, 794; ut salutaribus jejuniis eruditi, 838; and one which describes the Eucharist as the "unique healing remedy": Sumpto... unico ac salutari remedio, 1093. Once it is used in a very general sense for that which is supernaturally advantageous: abstrahatur a noxiis, et ad salutaria dirigatur, 154 . It seems to us that since the word always has something of the meaning of "supernatural wellbeing, salvation of soul", it may be considered as the adjectival form of the semantic Christianism, salus.

Then there are the various instances in which this adjective is related to the Christian new-form, salutare, with no hint of a medical application. Here it describes the inner effect of the sacramental action as "salvation-bringing". In postcommunions it occurs as: salutare(ia) sacramentum(a), 474, 997, 1087.2; salutare (ia) mysterium(a), 930, 1043, 1160 ; salutaria dona, 1136; munera salutaria, 586; oblatio salutaris, 578 . Worthy of special note, because of its unique form, is 932 ; it speaks of salutaris intercessio as an effect of the Eucharist ${ }^{1}$.

In six secrets - and we must always bear in mind that the secret is oratio super oblata - there is the prayer that the gifts may become salutaria, i.e. salvation-bringing: Munera tibi... nostrae devotionis offerimus, quae... nobis salutaria... reddantur, 707. Munus... tu salutare nobis perfice sacramentum, 713; also $8,586,812,986$. Again, the ritual action is referred to as haec hostia salutaris, 116 , or haec salutaris oblatio, 158 , or we pray: Benedictionem nobis... conferat salutarem sacra semper oblatio, 81 . Thus, the adjective, salutaris, is employed in secret prayers as it were by anticipation - as if the the ritual gifts were already in the state in which they will be by reason of the Eucharistic Prayer. L. Brou expresses it thus: “il est bien évident... que la prière de l'oblation n'est que le commencement d'un act où tout se tient, jusqu'à l'achèvement complet"2. However, when he says further that we may ask for the same graces at the offertory as we do after the reception of Communion, because the God whom we shall receive under the species of our transformed offering is the same to whom we have offered our material gift and has the same kindness at one time as at the other, it would seem that Brou is influenced too much by our modern way of thinking. Does not the use of the same terminology in secrets as in postcommunions rather point to a concept which is somewhat foreign to our minds today; viz., that the ritual act is a unity and as such is productive of the inner supernatural effect? The two may be considered as simul-

1 Cf. p. 160.

Cf. Brou, Les oraisons des dimanches, p. 111 ; cf also p. 76. 
taneous and coterminous. This manner of viewing the sacred rites is further evidenced by the fact that such a technical term as salutaris auxilii... effectum is seen as the result of the whole liturgical celebration - not just of the Eucharistic prayer as such - in the collect for the feast of the Beheading of St. John the Baptist; Sancti Joannis Baptistae... veneranda festivitas: salutaris auxilii nobis praestet effectum, 1032.

SALUTIFER, salvation-bringing ${ }^{1}$.

This adjective, which Krebs-Schmaltz say is foreign to strictly Classical Latin, was used by Ovid, Stat., Mart., etc. as the adjective of salus - obviously for stylistic reasons. In the orations it occurs in the sense of "salvation-bringing": per ejus salutiferae resurrectionis potentiam, 641. It was used also of the Holy Cross: salutiferae Crucis Inventione, 368, for the feast of May 3, which has been eliminated from the Missal.

SANARE, to heal.

This verb, which was the technical medical term for the therapy wrought by a physician, came, as did many other medical terms, to be used in the general sense of "antidote against any inconvenience" and then in the tropical sense of "healing spiritual or moral illness"2. It occurs only twice in the orations, both times in the moral signification of "to heal by chastising": qui nos et percutiendo (castigando) sanas, 463 and 791 . The rarity of this word may be due to two contributing factors: (1) it was a very common word in the ordinary language, and (2) it does not fall into the group - salus, salvare, salutaris, Salvator, and hence it does not suggest immediately the idea of supernatural salvation. The adjective, sanus, is absent, perhaps for the same reasons.

SANITAS, health ${ }^{3}$.

In Classical Latin this word meant "the proper quality of the body", and only in Late Latin did it take on the meaning of "physical health", especially in the sense of "a return to health", as related to the classical convalescere. In the prayer for the sick it has this proper literal sense: reddita sibi sanitate, 804 . That sickness is a consequence of sin is obvious from the history of the creation and fall of man. But the disorder which man suffered in his very nature as the result of sin is even worse than physical sickness. Hence he is in a true state of health only when his sins are forgiven; and this vera sanitatas is the burden of the request in the secret of Fer. IV post Dom. IV Quadr.: Supplices te rogamus... ut his sacrificiis peccata nostra mundentur; quia tunc veram nobis tribuis et mentis et 1 Cf. ForcelrinI-De Vrt, V, p. 319; Antibarbarus, II, p. 482.

- Cf. Eijkendoom, op. cit., p. 166 ff.; ForcellinI-DE VIT, VI, p. 332.

3. Cf. Antibarbarus, II, p. 486; Eijкengoom, op. cit., p. 189. 
corporis sanitatem, 1099. In the collect for Sancta Maria in Sabb., sanitas undoubtedly has the same meaning as it has above: Concede nos famulos tuos... perpetua mentis et corporis sanitate gaudere, 122.

viriosus, corrupt, faulty, defective' ${ }^{1}$.

This term was a technical medical term, but also a legal term used frequently in connection with the taking of auspices. From the context it can be seen that it is used with a medical connotation: quidquid in nostra mente vitiosum est, ipsorum (sacramenta) medicationis dono curetur, 121.

viTium, defect, fault ${ }^{2}$.

The original meaning of this noun was quite broad so as to include defects of any kind. It was especially common in medical terminology, where in contradistinction to morbus, it was used to designate the more or less permanent defects of parts of the body; e.g., blindness or lameness ${ }^{3}$. It came early to be used in the tropical sense and to be limited, as Krebs-Schmalz remark, to moral faults or errors. In the ORATIONs the medical figure is evident: Caelestem nobis praebeant haec mysteria... medicinam: et vitia nostri cordis expurgent, 85; Sanctificationibus tuis... et vitia nostra curentur, et remedia nobis aeterna proveniant, 1045; also $8,813,1044$. Then there is, as we have seen ${ }^{4}$, the medical connotation in connection with the practice of fasting: ut, dum a cibis corporalibus se abstinet, a vitiis quoque mente jejunet, 843 ; ut salutaribus jejuniis eruditi, a noxiis quoque vitiis abstinentes, 838; also, 656, 827, 850. No doubt the striving for a phrase balanced in thought as well as in form has also been a contributing factor toward the frequency of the juxtaposition of fasting from food to the refraining from sins.

In technical pagan religious terminology vitium referred to anything amiss in the auspices. There seems to be a hint at least of this religious sense behind a vitiis expiatos, 639 . However, vitium was also a general term for $\sin$ : a cunctis efficiant vitiis absolutos, 921 ; omnia in nobis vitiorum mala mortifica, 213. The passions are sometimes referred to as flames even in pagan authors; but the expression, vitionum nostrorum flammas in the collect of St. Lawrence, 178, and in the collect for Ember Saturdays, 452 , is undoubtedly used because it is a parallel to the references to flames in the martyrdom of St. Lawrence and in the fiery furnace respectively.

1 Cf. ForcellinI-De VIT, VI, p. 369.

2 Cf. Antibarbarus, II, p. 679; Forcellini-De VrT, VI, 370.

3 Cf. Cic., Tuse. 4, 13; and Index verborum in A Comelii Celsi quae supersunt recensuit Marx, Lipsiae 1915.

- Cf. p. 179 and 181. 


\section{BIBLICAL ELEMENTS}

In general, we must say that the ORATIONs have not been so strongly affected by Biblical influence as one could be inclined to suppose ${ }^{1}$. Some Scriptural elements do certainly exist, however. The very form of these prayers resembles the schema of ancient Jewish prayers ${ }^{2}$. Both contain a laudatory invocation of God. In the so-called Hebrew "blessings" (Beracha) a narration of one or other of the mirabilia Dei always followed the solemn calling upon God. In the ORATIONs we find this element frequently expressed in a relative clause as, for example, Deus qui nos per hujus sacrificii veneranda commercia, unius summae divinitatis participes effecisti, 409. It is true that the use of such relative clauses of praise was also rather common in pagan Greek and Roman prayers $^{3}$, so that we may conclude that this was an almost universal euchological form ${ }^{4}$ and was not restricted to Hebrew prayer. The concluding dexology, which is found invariably at the end of the ORATIONs, does not have a pagan parallel. It must surely owe its origin to Scriptural influence, especially that of the NT, where doxologies took on a more definite form than they had in the OT ${ }^{5}$.

\section{A. VARIOUS SGRIPTURAL REFERENCES}

In the first place, we must remember that there are Biblical elements concealed under the guise of Christianisms. Such, for example, are the names for "the people of God" : ecclesia", plebs", populus", familia"; words

1 Cf. Mohrmann, VG 4, 1950, p. 17, 67.

Cf. Baumstark, Comparative Liturgy, p. $63 \mathrm{ff}$.

- Cf. Rheinfelder, JLW 11, 1931, p. 20 ff., esp. p. 25 f.; Eduard Norden, Agnostos Theos. Untersuchungen zur Formgeschichte religiöser Rede, Leipzig-Berlin 1913, p. 168 f.

- Cf. Mohrmann, Liturgical Latin, p. 76.

- Cf. Eduard von Der Goltz, Das Gebet in der ältesten Christenheit, Leipzig 1901, p. $126 \mathrm{ff}$.

- Cf. p. $5 \mathrm{f}$.

C. p. 49 f.

C. p. 51.

- Cf. p. $154 \mathrm{f}$. 
indicating man as "the servant of God": famulus", servus"; terms representing the Kebod Jahweh: gloria ${ }^{3}$, claritas" $^{4}$, majestas ; and various other concepts: pax $^{6}$, nomen ${ }^{7}$, opus (in the sense of "good and evil works"), verbum ${ }^{9}$.

There are some instances, too, where the qui-clauses contain references to Scripture. The collect for the feast of the Chair of Peter is a case in point: Deus, qui beato Petro... collatis clavibus regni caelestis, ligandi atque solvendi pontificium tradisti, 280. Here the text of Mt. 16,1910 is molded to fit the rhythm and the tone of the prayer. The words claves, regnum, caelestis, ligare, and solvere are retained. Tradere is substituted for the more colloquial dare. We find such substitution also in the collect Ad postulandam humilitatem: Deus, qui superbis resistis, et gratiam praestas humilibus, 450, where praestare takes the place of dare which stands in 1 Peter 5,5, and James 4,6. At times the Scriptural references consist of a single word or phrase. The expression spirituales hostias, of the Vulgate, 1 Peter 2,5, is woven into the text of the secret for Fer. II infra Oct. Pent.: et hostiae spiritalis oblatione suscepta, 90711. The molding process goes even farther in the collect for Easter Monday: perfectam libertatem consequi mereatur, 448 ; here the adjective which modifies legem in the text of James: perspexerit in legem perfectam libertatis, 1,25, is made to apply to libertatem.

The characteristic which is peculiar to the so-called Psalter Collects ${ }^{\mathbf{1 2}}$, namely, to begin the prayers with a quotation from a Psalm ${ }^{13}$, is almost non-existent. An excellent example of this phenomenon though, is found in the prayer over the people for Monday of Holy Week, the opening words of which are taken from Ps. 78,9: Adjuva nos, Deus salutaris noster, 41. The collect for Dom. XXII p. Pent, furnishes another illustration. This time it is Ps. 45,2, which constitutes the introduction

1 Cf. p. 30.

Cf. p. 57.

3 C. p. $32 \mathrm{f}$.

- Cf. p. 24.

- Cr. p. 40 f.

- Cf. p. 47.

' Cf. p. $42 \mathrm{f}$.

C. p. 44 f.

- Cf. p. 58.

10 Et tibi dabo claves regni caelorum. Et quodcumque ligaveris super terram, erit ligatum et in caelis; el quodoumque solveris super terram, erit solutum el in caelis.

11 Cf. p. 76.

12 These collects have been edited by Lours Brou; The Psalter Collects, from V-VIth Century Sources. Edited from the Papers of the Late Dom Andre Wilmart, London 1949.

13 Cf. Crur. Mohrmann, A propos des Collectes du Psautier, VC 6, 1952, p. 1 f., esp. p. 7. 
to the prayer: Deus, refugium nostrum et virtus, 461 . Ps. 83,10, also occurs twice at the head of ORations: Protector noster aspice, Deus, 912, 914.

The most interesting Biblical element in the ORATIONs is the use of Ps. 115,8, (116,17), and (or) of Ps. 106,22, (107,22). There are variant readings of these verses. Of the former they are as follows:

tibi sacrificabo hostiam laudis, Vulg. 117,8.

tibi sacrificabo sacrificium laudis, Cas. cod. $557^{1}$

tibi immolabo hostiam laudis, Iuxta Hebr ${ }^{2}$.

Ps. 106,22, shows the following variants:

Et sacrificent sacrificium laudis, Vulg.

et immolent hostias gratiarum, Iuxta Hebr.

The ORATIONs, perhaps under the influence of various readings in the different versions of the Psalms, or simply for the sake of adapting the Scripture text to the prayer, have an even wider variety of versions. These fall into three principal categories. (1) The verb sacrificare is maintained: ut sacrificare tibi hostiam laudis, $472^{3}$. (2) The verb immolare and the noun hostia are retained: tibi laudis hostias immolamus, 70; laudis tibi hostias immolamus, 195,664; hostiam laudis tibi immolamus, 906. (3) Six times the verb offerre, which is a technical term for the Eucharist, replaces the Biblical terms for "to offer": Hostias tibi... laudis offerimus, 623; hoc sacrificium laudis tuae offerimus (obtulimus) majestati, 683, 877; sacrificium tibi... laudis offerimus, 893, 1017; tibi offerimus sacrificium laudis, 905. Noticeable, too, are various stylistic expansions. For example, tibi is replaced by tuae majestat in 683 and 877 ; hostiam laudis is expanded to hostias placationis et laudis, 53, 580; and finally, there is the hendiadys: Offerimus tibi... laudes et munera, 739, with the further substitution of the technical term munus for sacrificium or hostia. This is another vivid illustration of the liturgy's tendency not to quote Sacred Scripture verbatim but to mold it into the structure of the prayers ${ }^{5}$.

It is interesting to note that beside the variety which is displayed in the orations, there is comparative uniformity in the use of this Psalm text in the opening sentences of the Eucharistic prayers in the nonRoman Latin usages. In these latter the verb immolare and the noun hostia occur at least eleven times ${ }^{6}$, while sacrificare is not found at all,

1 Cr. Robert Weber, Le Psautier Romain et les autres anciens Psautiers latins. Edition critique, Città del Vaticano 1953, p. 288.

a Cf. Henri de Sainte-Marre, Sancti Hieronymi Psalterium iuxta Hebraeos. Edition critique, Città del Vaticano 1954, p. 170.

C. p. 78.

- Cf. p. 82.

- Cf. Mohrmann, VC 4, 1950, p. 18.

- FÉrotin, Liber Mozarabicus, 277, 652, 879, 1216, 1235, 1331, 1420; H. M. BAN- 
and only once does offerre replace immolare ${ }^{1}$. Curious, though, is the fact that in the Veronense the phrase: hostias tibi laudis offerimus occurs 8 times at the closing of VD passages ${ }^{2}$, but that, when the phrase appears at the beginning of the passage, it is cited as follows: tuae laudis hostiam iugiter immolantes. ${ }^{3}$. Once again we witness here how stylization in the form of striving for effective language, the use of fixed expressions, and especially rhythm have affected the composition of these exalted prayers.

In conclusion, we may note that the frequency of the reference to Ps. 115,8 and (or) 106,22 , indicates pointedly that the concept of the Eucharist as a sacrifice of praise was very much alive at the time when these prayers were composed.

\section{B. DIVERSE TERMS WITH BIBLICAL BAGKGROUND}

AURIs, ear.

The material in the Thesaurus shows that this noun was used a few times by pagan authors also in petitioning for a favorable hearing of their prayers, but that it was much more frequent in Jerome and other Christian authors ${ }^{4}$. It is rare, too, in the orations. It forms part of an almost literal quotation from Ps. 87,3 in: Inclina... aurem tuam ad preces nostras, $644^{5}$. In addition, we have: Aurem tuam... precibus nostris accommoda, 64; cunctis petentibus aures tuae pietatis accomodes, 941; and Pateant aures misericordiae tuae, 807.

\section{CONSPECTUS, sight, presence.}

This noun, which is found in Ennius and Plautus but was rare in Classical authors, occurs some 430 times in the Vulgate 6 . It is rare in the orations also. Three times it appears in secrets, where there is reference to gifts being acceptable "in the sight of God"; Accepta sit in conspectu tuo... nostra devotio, 8; Sacrificia... tuis oblata conspectibus, 1004; ut tuo sint digna conspectu, 1116. It also means "in the presense of" in the prayer for the blessing of ashes: ante conspectum divinae clementiae tuae, 769.

Noteworthy is the fact that facies does not occur in the special sense of "the face of God", and vultus appears but once in a very affected NISTER, Missale Gothicum, London 1915, 270, 398, 418; E. A. LowE, The Bobbio Missal, London 1917, 453.

1 Ferotin, Liber Mozarabicus, 1284.

2 Mohlderg, 29, 202, 285, 314, 718, 728, 760, 767.

3 Mohlberg, 1250.

- Cf. TLL II, p. 1508.

5 Cf. p. 192 for discussion of the Psalter Collects.

- Cf. Dutripon, op. cit., p. 258 f. 
phrase of the postcommunion for good weather: ut inundantiam coerceas imbrium et hilaritatem vultus tui nobis impertiri digneris, 934.

DEXTERA, the right hand of God, symbol of His power.

This figure of the glorious power of God occurs frequently in Sacred Scripture, especially in the Psalms $\mathbf{1}$. A classic example is: Dextera Domini fecit virtutem, Ps. 117,5.

The dextera of the Lord is identified with His power in: contumaciam (inimicorum) dexterae tuae virtute prosterne, 628; and in: dum quod uni populo, a persecutione Aegyptiaca liberando, dexterae tuae potentia contulisti, 211. It is characterized as divine help in: Pretende... fidelibus tuis dexteram caelestis auxilii, 880; and as divine mercy in: dexteram super nos tuae propitiationis extende, 66. By joining dextera with majestas, the accent seems to be placed upon the glorious property of God's power in: dexteram tuae majestatis extende, 764, 884, 9502. Even when it is used absolutely, it is evident that dextera means the protecting power of God: Tueatur... dextera tua populum, 1154. Though it may refer literally to the right hand of the Savior in: Deus, cujus dextera beatum Petrum ambulantem in fuctibus, ne mergeretur, erexit, 212, still there is no doubt that the symbolic element of the word is strongly suggested. Christ may be considered as the incarnate revelation of the power of God. Note that the prayer is addressed to Deus, which in the ancient orations means God the Father. Furthermore, in all the sources before the Lateran Missal (1112th cent.) this collect ends with Per Dominum nostrum... ${ }^{3}$.

ERRARE, to stray4.

This figure was used already in the OT for those who were unfaithful to Jahweh; but in the NT it received a new emphasis in connection with the parable of the Good Shepherd: si alicui centum oves, et erraverit una ex eis, Mt. 18,125. It has found its way into only two ORATIONs. Since there is mention of lumen veritatis in the collect for Dom. III p. Pasch.: Deus, qui errantibus, ut in viam possint redire justitiae, veritatis tuae lumen ostendis, 336, the errantes must be those in error of an intellectual

1 Cf. Dutrmon, op. cit., p. 337 f.; BRou, Les oraisons dominicales, p. 86.

- N.B. the influence of the curial style may have been a contributing factor here. See p. 40.

3 Cf. Bruylants, Les oraisons, II, p. 66, apparatus criticus. For a discussion of the regular custom of addressing prayer to the Father and closing with the formula expressing the mediatorship of Christ: Per Dominum..., see J. A. Jungmann, Die Stellung Christi im liturgischen Gebet ${ }^{2}$, Münster in Westf. 1962, p. 150 ff., 198; Missarum Sollemnia, I, p. 106, 486.

- Cf. TLL V, 2, p. $806 \mathrm{ff}$.

Cf. also Is. 53, 6; Ez. 34, 5; 5, 4; Jn. 10, 12; 1 Peter 2, 25. 
rather than of a purely moral nature ${ }^{1}$. The meaning of this participle is definitely specified also when it occurs in the solemn prayer for unity of the Church on Good Friday: ut omni haeretica pravitate deposita, errantium corda resipiscant, 799.

GRADI, to advance.

According to the Concordantiae, this verb does not occur in the $\mathrm{NT}^{2}$, but it is rather frequent in the OT and in Christian authors. It appears twice as a figurative expression of our advance to God, both times in the identical phrase: per ejus ad te exempla gradiamur, 376, 459. Gressus, which was frequent in the Bible in the metaphorical sense of "living", is also found but once, and that in a phrase which is taken from Ps. 16,5: perfice gressus nostros in semitis tuis, 397. Transgressio, a Scriptural term for sin, does not appear.

viA, way, conduct.

An eminently Biblical idea is that of preparing the way of the Lord. Already in the OT this figure was used to indicate the preparedness required of the people of Jahweh so that He might again be their leader as He had been across the Red Sea, the desert and into the land of promise. This noun is found once with this meaning in the ORATIONS, namely, in the collect for the second Sunday of Advent: Excita... corda nostra ad preparandas Unigeniti tui vias, 542. The Biblical connotation is also included in the word when it appears in the collects for the vigil and for the feast of St. John the Baptist, who called himself the voice of one crying in the wilderness: "Prepare ye the way of the Lord". On the vigil we pray: Praesta... ut familia tua per viam salutis incedat, 856; and on the feast: omnium fidelium mentes dirige in viam salutis aeternae, 436.

The representation of life as a way is not peculiar to Biblical thought; it was found in the Hellenistic world as well ${ }^{4}$. This general sense of via as "conduct, way of life" occurs twice in the orations; viz., in the collect and in the secret of the votive Mass for travellers. In both of these there is a play on the double meaning - the literal and the figurative - of the word: viam famulonum tuorum in salutis tuae prosperitate dispone: ut inter omnes viae et vitae hujus varietates, tuo semper protegantur auxilio,

1 C. Brou, Les oraisons dominicales, p. 119 f.

Cf. Dutrupon, op. cit., p. 576.

3 Cf. Is. 40, 3; Mal. 3, 1; Jn. 1, 23; Mt. 3, 3; Mk. 1, 3; Lk. 3, 4.

- Cf. O. Becker, Das Bild des Weges und verwandte Vorstellungen im frithgriechischen Denken, Berlin 1937, passim: F. Cumont, Lux perpetua, Paris 1949, p. 278 ff.; Jean Daniélou, Théologie du Judéo-Christianisme, Paris-NewYork-Rome 1957, p. 38; Jean-Paul Audet, La didachl. Instructions des apôtres, Paris 1958, p. 254 ff. 
30; viam illorum et praecedente gratia tua dirigas, et subsequente comitari digneris; ut de actu atque incolumitate eorum, secundum misericordiae tuae praesidia gaudeamus, 902. There is something of the notion of the "two ways" evident in the collect for the third Sunday after Easter; for there is a question of "returning" to the "path of justice", which in this instance means the true Faith".

${ }^{3}$ For discusion of this collect see p. 195. 


\section{CONGLUDING REMARKS}

This study, although it by no means pretends to be exhaustive, has served to reveal some salient features of the language of the ORATIONs and to disclose therein a number of nuances regarding the concept of the ritual action, as well. The fact which is at once evident is the relative poverty of the vocabulary, and this in spite of the fact that there is a definite loftiness of expression and a patent striving for effect. Even a cursory glance at these prayers reveals a certain monotony of words and style. In the concrete, this lack of variety is revealed in several areas.

As an instrument of religious expression, the hieratic language of the ORATIONs repeats words and phrases which tend to be more lofty than the ordinary every-day language. The result is a frequent recurrence of formulae, stereotyped and determined once and for all in view of a definite situation. We have seen many such formulae: Adesto supplicationibus nostris, supplices te rogamus, intercedente(-bus) beato $\mathcal{N}$. (sanctis), annua solemnitate laetificas, proficiat ad salutem, to mention but a few representative examples. Thus the component parts of the ORATIONS are often drawn from the stock of traditional sacral phrases that the long period of improvisation or at least of free composition has brought into existence. Such fixed expressions, often highly rhetorical, have many times been fitted together like the parts of a mosaic and patterned into prayers at once new and still familiar-sounding. This is clearly displayed, for instance, in the prayers containing the expression praesens vita, cited on p. 60. Borrowings from the highly stylized language of the court have, in their turn, also led to a relative banality which is caused by the repetition of formulary turns of speech. This phenomenon is evidenced in such phrases as: majestatem tuam deprecamur, pietati tuae nos reddat acceptos, quaesumus clementiam tuam, and preces humilitatis nostrae, in which majestas, pietas, clementia and humilitas are little more than expressions of urbanity. Finally, there is the oftrecurring use of certain periphrastic constructions. One such is the 
formation with mereri. Of the 45 times that this verb occurs in the ORATIONS, only four have the meaning of "to merit" in the strict sense of the word. In the rest it is a term of reverence which implies the reception of a "free gift" for which one depends entirely on the benign favor of God. The note of reverence is even more noticeable in the constructions with dignari. That it is evidently a literary convention can be seen, for example, from its use in the postcommunion for Fer. VI infra Oct. Pasch., where we find: quem aeternis dignatus es renovare mysteriis, 985, while in less artificial speech one would simply have said: quem... renovasti. Most of the time, dignari is used as a mark of respect in petitions of the sort that have become so familiar to us in the Litany of the Saints. It must always be borne in mind that these prayers were "chanted" aloud by the celebrant in the name of the congregation. Hence, rhythm is one of the most important factors contributing to the recurrence of the periphrastic constructions and other stylistic formulae. We quote a salient example. In the clause: et Sancti Spiritus gratia illuminare digneris, 602 , which is but one of the fifteen periphrases with dignari found in the ORATIONs, this verb is clearly used for reasons of rhythm.

The vocabulary has not only been limited by reason of the abundant use of fixed formulae and periphrastic constructions, but stylization has also led to restrictions in the choice of words. This is evidenced by the fact that Christian loan words seldom make their appearance, except for the very usual ones, such as ecclesia, or martyr. Then, too, there is a conscious striving to avoid Christian colloquialisms, because these lack the note of solemnity required for the highly rhetorical tone of the official euchology. Thus, only very few words ending in -ficare have found their way into the orATIONs, and of these, sanctificare, laetificare and purificare ${ }^{1}$ have a special liturgical sense. Again, some very usual Christian terms have been supplanted by others which have a loftier tone: the humble servus, for instance, is superseded by famulus of poetic origin, and humiliter is replaced by the stylized suppliciter. Such examples could be multiplied. One word system which is conspicuously scarce is the martyr terminology. Corona, palma, victoria, each occur but once. Pati, in the sense of "to suffer martyrdom", does not appear, and passio is rare. Confessio is used a few times for the act of martyrdom. It is striking, too, that the Biblical confiteri in the meaning of "to praise" does not occur either.

1 We have not had occasion to treat the word purificare in the preceding text, but we may say that of the 26 times that it is found in the orations, at least 18 allude specifically to the action of the sacred rite, as the following examples illustrate: Munera nos... oblata purificent, 691; Oblatio nos...tuo nomini dicanda purificet, 727. 
The study of the word meanings makes it clear that within the structure of these public prayers a number of Christianisms have adopted a new liturgical sense. Benedictio and sanctificare are cases in point. Spiritaliter has received the added nuance of "the inner spiritual effect of the sacred action" by reason of its being juxtaposed to terms describing the external rite. Even gloria is at times to be interpreted as "a specific act of cultic homage".

We may now summarize some of the noteworthy facts concerning the words with a technical liturgical sense.

On the whole, the terms referring to the Eucharist are the same as those usually employed for it in Christian Latin in general. Mysterium, sacramentum, hostia, oblatio, offerre, sacrificium, etc. are traditional designations for the Eucharist as such, as well as for the act of offering. We may consider munus, in the sense of "gift", as coming from the general speech, whereas its meaning as "official function, duty" must be regarded as being derived from legal terminology. Sacrare, consecrare, and immolare are borrowed from pagan Roman prayer terms. For the action of God in regard to the gifts, there are words expressing three types of activity. Two of these are common both to Biblical and to profane Latin, namely those indicating acceptance (e.g., accipere, suscipere, assumere) and those denoting a favorable glance (as intendere, respicere). The third type, sanctificare, represents a semantic development of a Ghristian new-form.

Several interesting philological facts are brought out also in the consideration of the terms designating the performance of the cultic act. Here we find a number of words with broad general meanings, such as agere, gerere, exsequi, etc. These tend to adopt a technical cultic sense within the framework of the ORATIONs. However, as the excursus on agere, actio has demonstrated, the possibility of polysemy must always be taken into consideration, for the contexts in which these words appear in the Gel. Vetus, the Gregorianum, and the orations of the MR by no means warrant our interpreting them always in a ritual sense. Another characteristic of liturgical Latin, namely its concreteness, is eminently displayed in this section. Actio, obseroatio, officium, and the rest, when they have a ritual sense, refer to an actual sacred action here and now in progress. So, too, devotio, honor, veneratio, not only indicate interior sentiments, but they especially refer to these sentiments as concretized in a specific ritual performance. The names given to the liturgical celebrations display two points of view. On the one hand, they are regarded as "festivities" with the accent on the religious com- 
memoration of an event. Here we have such words as festivitas, solemnitas, commemoratio. On the other hand they are regarded as a concrete ritual act itself, as solemnia and festa.

If the language of the ORATIONs reveals throughout a relative poverty, then this is especially the case in regard to the prayer terms. The ancient Christian word for prayer, orare, which had become quite colloquial, occurs but once in the body of the prayers; its nomen actionis is found 18 times, of which 13 have the legal connotation, "intercession". However, the verb is maintained in the fixed invitation, "Oremus", and the noun "oratio" is the technical name for these prayers. Rogare and petere, also seem to be too colloquial to appear very often; even precari is not found. It is here that terms from group languages play an important role. Preces, which might be considered the chief staple of ancient pagan Roman prayer terminology, is the most regularly used word for prayer, as petition, as an element of the sacrifice, and as intercession. An even clearer evidence that the borrowings from group languages is a stylistic device can be seen from the use of such terms as supplices and suppliciter. These not only serve to add emphasis to a colloquial word as rogare or to replace one as humiliter; but they also compensate for the Late Latin weakening of the prepositional suffixes in such words as deprecari or exorare.

Also symptomatic of the meagerness of the vocabulary of prayer is the abundant use of fixed formulae with the imperative. It is here that the ever-present quaesumus, which was also an important word in pagan prayer, figures so prominently. In the orations it is always found in the one form, namely the first person plural of the present indicative. Da, Fac, Praesta, Concede, Intende, Accipe, and the rest, are almostinvariably followed by this word which already in in pre-Classical Latin was enclitic. Thus, quaesumus serves a double function: it tones down the imperative, which man has no right to direct to God, and it enhances the rhythm. Propitius, another very ancient Roman element, serves this same two-fold purpose.

The consideration of the terms designating the effects of the sacred action has revealed that, here too, a number of words with a very broad and general meaning are employed with a special, almost technical sense. Effectus, operatio, operari, virtus designate the supernatural dynamism of the ritual action. Words like proficere, prodesse, etc. bring out the concept of movement toward a goal, while capere, consequi, participatio, indicate "a sharing in" and "a union with" the sacred mysteries.

On the whole, the study of these words with a technical liturgical meaning has resulted in some interesting conclusions as to the general trends of thought which lie behind these prayers. Again we note a 
number of characteristic examples.

We may mention as a first point the emphasis which is laid on the ritual character of the Eucharistic celebration, and this particularly in reference to the parts which we call the Offertory and Communion. We have seen from the contexts of secret prayers that the gifts offered - hostia, oblatio, munus, sacrificium - form an essential constituent of the ritual act which is performed with and over them. Frequently, indeed, these very terms stand for the sacred rite itself. This same ritual notion is evident in words indicating participation in the Eucharist. The use of mysterium and sacramentum predominently in postcommunions and the employment of such a word as munus with terms designating the taking of nourishment indicate that participation in the Eucharist is regarded as a ritual eating and drinking rather than as andividual personal "reception" of Christ into one's soul.

Furthermore, the added factor that the same terminology is often employed in secrets as in postcommunions shows that the rite is visualized as a unity. The moments - Offertory, Consecration and Communion - are by no means separated, nor even sharply distinguished from each other. We have seen this in numerous secret prayers, for example: Munera, quae tibi... pro sancti Martyris tui Joannis Baptistae passione deferimus: quaesumus; ut ejus obtentu nobis proficiant ad salutem, 701, or Haec oblatio... ab omnibus nos purget offensis, 592.

What is more, the theandric nature of the ritual action is brought to the fore by the fact that the rite itself is regarded as productive of supernatural effects. Note how clearly the secret for Dom. IV p. Epiph. expresses this: Concede... ut hujus sacrificii munus oblatum, fragilitatem nostram ab omni malo purget semper, et muniat, 130. This has also been pointed out in the study of the terms designating the cultic act as well as in those which have a reference to its inner efficacy. The employment of a single object, for example, both for the verb (agere, gerere, etc.) indicating the ritual action and for that representing the inner spiritual efficacy (consequi, perficere, etc.), as in: quae temporaliter agimus, spiritualiter consequamur, 718 , and quod agit mysterio, virtute perficiat, 81 , is evidence also that both divine and human elements are present in the rite.

We have already touched upon some of the borrowings from group languages, and we have seen that they are chiefly a matter of style. This needs to be emphasized especially in regard to legal terms lest one fall into the error of interpreting the ORATIONs too legalistically. It is but normal, of course, that the borrowings from prayer terminology are usually such as have to do with sacrifice and prayer. So too, we expect 
to find that the terms for the intercession of the saints - intercedere, intercessio, intervenire, commendare, and the like - and names for sin and its forgiveness be appropriated from legal language. In this latter group are such words as: indulgere, nexus, reatus. Military terms are comparatively rare, though praesidium, munire and subsidium are used to describe results of sacrificial action. The only remnant of Early Christian terminology in this field is the expression militia Christiana. Medical terms are employed especially in two areas: the effect of fasting and the effect of the Eucharistic action. Remedium and medela mean both "remedy" and the "state of health" resulting from the remedy.

The Biblical influences are chiefly indirect, i.e., by way of words which had become a standard part of the Christian language. The use of Ps. 115,8 is the most evident borrowing from Sacred Scripture.

There remains a word to be said about two stylistic devices which we have found very often in the ORATIONs and which have a definite bearing on the interpretation of the texts of these prayers. The first regards the use of the gerundive in its primitive import, where neither future nor modal signification is present. This stylization occurs exclusively with words which have a ritual sense - sacrare, consecrare, celebrare, venerari, dicare, immolare, offerre, sumere. Hence, besides adding a certain loftiness of tone, this use of the gerundive emphasizes the unity of the cultic act which is hic et nunc in progress. The frequency of this same construction in ancient pagan prayer indicates that there is something typically Roman about it.

The genitivus inhaerentiae (genitive of identity) also merits a special remark. Svennung says that is is "echtlateinisch" but is often found in an exaggerated abundance in speech which is highly rhetorical. It is not surprising, then, that we find such phrases as: munus gratiae 442, donum gratiae, 401 , potestate virtutis tuae, 434 , in the exalted language of the orations. And here, once again, we have noted that the ritual terms are the ones which are found the most frequently in this genitive construction: sacra observationis jejunia, 896, munus hujus sacrificii, 130, sacrificii praesentis oblatio, 1073, cum oblationibus hostiarum, 1106, 1130, 1131, hujus oblationis hostiam, 1039. The fact that there is no set pattern as to which ritual words are used in the genitive indicates that the two nouns in the various groups are indeed identical in meaning. It stands to reason, too, that extra emphasis is laid upon the cultic act by the exalted tone which the genitivus inhaerentiae creates. It is very important for an understanding of the true meaning of the words involved, that one be aware of the existence of these stylistic decorations. 


\section{TABLE LISTING ORATIONS STUDIED}

The following table lists the orations included in this study. The numbers represent those given to the prayers by P. BRuYlants in Les oraisons du Missel Romain, II. The second column lists the technical name of each prayer as it appears in the MISSALE ROMANUm. Finally, the third column lists the occasion on which the prayer is used. Since the purpose of this table, besides listing the prayers studied, is to indicate where each one is to be found in the MISSAIE ROMANuM, it seems sufficient to note only one occasion of usage in cases when a prayer is used on two or more occasions. However, this fact will be indicated by an asterisk (*).

\begin{tabular}{|c|c|c|c|c|c|}
\hline No. & $\begin{array}{l}\text { Use in } \\
\text { Missal }\end{array}$ & Occasion & No. & $\begin{array}{l}\text { Use in } \\
\text { Missal }\end{array}$ & Occasion \\
\hline 1 & Or. & Ad poscenda suf. Sanct.* & 36 & Postcom. & Fer. II infra Oct. Pen \\
\hline 2 & Postcom. & Dorn. III in Quadr." & 37 & Or. $3 \mathbf{a}$ & Sabb. Quat. Temp. Quadr. \\
\hline 3 & & Ad repellendas tempestates. & 38 & Sup. Pop. & Fer. II p. Dom. II Quadr.* \\
\hline 4 & Postcom. & Fer. IV infra Oct. Pash. & 39 & Or. & In Consecr. Episcopi. \\
\hline 5 & Postcom. & Pro Defunctis, $n^{\circ} 5$ & 41 & Sup. pop. & Fer. II Maj. Hebdomadae. \\
\hline 6 & Sup. Pop. & Fer. II p. Dom. I Quadr. & 44 & Or. & Fer. III infra Oct. Pent. \\
\hline 7 & Or. & Dom. XXIII p. Pent. & 51 & Or. & Pro Defunctis, $n^{\circ} 17$ \\
\hline $\begin{array}{r}8 \\
11\end{array}$ & $\begin{array}{l}\text { Secr. } \\
\text { Secr. }\end{array}$ & $\begin{array}{l}8 \text { Aug. Ss. Mart." } \\
\text { Fer. VI Ouat. Temp.Sept.* }\end{array}$ & 52 & Postcom. & $\begin{array}{l}\text { Pro omnibus fidelibus de- } \\
\text { functis." }\end{array}$ \\
\hline 12 & Secr. & $\begin{array}{l}\text { In Nat. Dom. Ad primam } \\
\text { Missam. }\end{array}$ & $\begin{array}{l}53 \\
54\end{array}$ & $\begin{array}{l}\text { Secr. } \\
\text { Secr. }\end{array}$ & $\begin{array}{l}\text { Fer. IV p. Dom. Pass. } \\
12 \text { Mart. }\end{array}$ \\
\hline 13 & Secr. & 22 Aug. Pro Ss. Mart.* & 55 & Secr. & Dedicationis Eccl.* \\
\hline 17 & Secr. & $\begin{array}{l}25 \text { Dec.Com. S. Anastha- } \\
\text { siae Mart." }\end{array}$ & $\begin{array}{l}56 \\
57\end{array}$ & $\begin{array}{l}\text { Or. } \\
\text { Secr. }\end{array}$ & $\begin{array}{l}22 \text { Sept. Ss. Mart. } \\
25 \text { Jan." }\end{array}$ \\
\hline 18 & Or. $5 \mathrm{a}$ & Sabb. Quat. Temp. Quadr. & 59 & Sup. pop. & Fer. III p. Dom. I Quadr. \\
\hline 22 & Or. & Ad post. serenitatem. & 63 & Postcom. & Dom. II p. Epiph. \\
\hline 23 & Sup. Pop. & Fer. V p. Dom. II Quadr. & 64 & Or. & Dom. III Adventus. \\
\hline 25 & Or. & 15 Sept. S. Nic. Mart. & 65 & Postcom. & 26 Dec.* \\
\hline 26 & Secr. & 11 Aug. & 66 & Or. & 22 Aug. Ss. Mart. \\
\hline 28 & Or. & Sabb. p. Cin & 68 & $\mathrm{O}$ & 22 Julii. \\
\hline 29 & Or. & 9 Aug. Vig. S. Laur. & 69 & $\mathrm{O}$ & 21 Sept. $*$ \\
\hline 30 & Or. & Pro peregrinantibus. & 70 & $\mathbf{S}$ & 24 Aug. \\
\hline 31 & Or. & Justus".* & 71 & Postcom. & 25 Julii. \\
\hline 32 & Or. & 22 Jan. Ss. Mart.* & 72 & Postcom. & 29 Sept.* \\
\hline 33 & Postcom. & Dom. prima Pass." & 73 & Postcom. & 23 Junii. \\
\hline 34 & Postcom. & Dom. IV p. Pascha. & 74 & Secr. & 25 Aprilis. \\
\hline 35 & Postcom. & 21 Dec.* & 75 & Or. & 16 Sept. Ss. Mart.* \\
\hline
\end{tabular}




No. Use in Occarion No. Use in
Missal
Missal

\begin{tabular}{|c|c|c|c|c|c|}
\hline $\begin{array}{l}76 \\
77\end{array}$ & $\begin{array}{l}\text { Or. } \\
\text { Or. }\end{array}$ & $\begin{array}{l}11 \text { Sept. Ss. Mart.* } \\
25 \text { Oct. Ss. Mart. }\end{array}$ & 164 & Postcom. & $\begin{array}{l}\text { In Nativitate Dom. Ad pri- } \\
\text { mam missam. }\end{array}$ \\
\hline 80 & Secr. & 8 Nov. Ss. Mart. & 165 & Or. & 26 Dec. \\
\hline 81 & Secr. & Dom. II p. Pascha. & 166 & Sup. pop. & Fer. III p. Dom. I Pass. \\
\hline 82 & Postcom. & Pro peste animalium. & 167 & Or. & Tempore famis." \\
\hline 85 & Secr. & Dom. XX p. Pent. & 168 & Postcom. & Ad petendam pluviam. \\
\hline 92 & Postcom. & $13 \mathrm{Jan}$. & 169 & Postcom. & 24 Dec. \\
\hline 95 & Postcom. & Fer. V p. Dom. IV Quadr. & 170 & Or. & Dom. IV p. Pent. \\
\hline 97 & Postcom. & Dom. VI p. Epiph.* & 174 & Or. 2a & Sabb. Quat. Temp. Sept. \\
\hline 01 & Postcom. & 8 Nov. Ss. Mart. & 175 & Sup.pop. & Fer. VI p. Dom. IV Quadr. \\
\hline 44 & Postcom. & Fer. V post Cineres.* & 176 & Or. & Dom. Ad s \\
\hline 66 & Postcom. & Pro Defunctis, $n^{\circ} 11 .^{*}$ & & & $\mathbf{m}$ \\
\hline 17 & Postcom. & Sabb. post Cineres. & 177 & Secr. & 24 Dec. \\
\hline 5 & Postcom. & & 178 & Or. & 10 Aug. \\
\hline 16 & Secr. & IV p. Pent.* & 179 & Postcom. & 9 Aug.* \\
\hline 17 & Or. & erum. & 180 & Postcom. & 1 Nov." \\
\hline $119^{1}$ & Secr. & Mart. & 181 & Or. & Sabb. p. Dom. II \\
\hline 20 & Secr. & Pent. & 182 & Sup. pop. & Fer. V p. Dom. I \\
\hline 21 & Postcom. & XIV p. Pent. & 183 & Or. & Dom. XVII p. Pent. \\
\hline 122 & Or. & Maria in Sab." & 184 & Sup. pop. & Fer. VI p. Dom. II Quadr." \\
\hline 124 & Secr. & Sabb. in Albis. & 185 & Or. & Fer. VI Quat. Temp. Pent. \\
\hline 127 & Postcom. & $\begin{array}{l}\text { Ad postulandam gratiam } \\
\text { Sp. S. }\end{array}$ & $\begin{array}{l}187 \\
188\end{array}$ & $\begin{array}{l}\text { Or. } \\
\text { Postcom. }\end{array}$ & $\begin{array}{l}13 \text { Aug. Ss. M } \\
\text { Fer. III p. D }\end{array}$ \\
\hline $\begin{array}{l}128 \\
130\end{array}$ & $\begin{array}{l}\text { Or. } \\
\text { Secr. }\end{array}$ & $\begin{array}{l}14 \text { Jan. S. Mart." } \\
\text { Dom. IV p. Epiph." }\end{array}$ & 189 & Or. & Anasta- \\
\hline 131 & Or. & Dom. Ad ter- & $\begin{array}{l}190 \\
191\end{array}$ & $\begin{array}{l}\text { Or. } \\
\text { Or. }\end{array}$ & a.* \\
\hline 32 & Secr. & lat." & 192 & O & $\mathbf{F e}$ \\
\hline 33 & Postcom. & Pasch. & 193 & O & [ p. Dom. II Quadr. \\
\hline 134 & Or. & Quadr. & 195 & Secr. & $21 \mathrm{D}$ \\
\hline 5 & Or. & $\mathrm{Sa}$ & 196 & Or. & Pro \\
\hline 6 & Or. & ione Don & 197 & Sup. pop. & Dom. IV Quadr. \\
\hline 37 & Sup. pop. & Quadr.* & 198 & Secr. & In \\
\hline 9 & Or. 2 & dv. & 199 & $\mathrm{Or}$ & Dc \\
\hline 142 & Postcom. & & 200 & Or. & a Dom.* \\
\hline 143 & Or. & p. Dom. I & 201 & Or. & Mis \\
\hline 145 & Or. & $\mathbf{F e}$ & 204 & Postcom. & Mi \\
\hline 146 & Or. & [I Quadr. & 205 & Or. & anc. Post proph \\
\hline 150 & Post & $2 \mathrm{~J}$ & & & \\
\hline 154 & Or. & IV p. Pent. & 206 & $\mathrm{O}$ & gratiam S \\
\hline 155 & Or. & Ss. Mart. & 208 & $\mathrm{O}$ & In \\
\hline $6^{\mathbf{2}}$ & Secr. & Pro & & & \\
\hline 157 & Postcom. & Pro: & 209 & Secr. & is de defunctis. \\
\hline 158 & Secr. & KII p. Pent.* & 210 & Postcom. & Pro Defunctis, $n^{\circ} 16$ \\
\hline 161 & $\begin{array}{l}\text { Or. } \\
\text { Or. }\end{array}$ & $\begin{array}{l}\text { Pro } \\
21 \mathrm{D}\end{array}$ & 11 & & $\begin{array}{l}\text { Sabb. Sanct. Post Prophe- } \\
\text { tiam II. }\end{array}$ \\
\hline & Or. & $6 \mathrm{Mz}$ & 12 & O & Missa de Ss. Petro et \\
\hline
\end{tabular}




No. Use in Occasion No. Use in Occasion
Missal
Missal

\begin{tabular}{|c|c|c|c|c|c|}
\hline 213 & Or. & 28 Dec. & 351 & Or. & 6.Jan. \\
\hline 214 & Or. & Pro Defunctis, $\mathrm{n}^{\circ} 15$. & 352 & Or. & 29 Junii. \\
\hline 217 & Secr. & Pro Defunctis, $n^{\circ} 14 .^{\star}$ & 353 & Secr. & Tempore famis. \\
\hline 219 & Secr. & Missa pro infirmis. & 358 & Postcom. & Ad repell. malas cogita- \\
\hline 220 & Or. & Dom. VII p. Pent." & & & tiones. \\
\hline 221 & Or. & $13 \mathrm{Jan}$. & 364 & Or. & Dom. II p. Pasch. \\
\hline 223 & Postcorn. & Pro Defunctis, $n^{\circ} 15$. & 367 & Or. & Sabb. Sanct. Post prophe- \\
\hline 225 & Postcom. & Missa „Sacerdotes tui”." & & & tiam III. \\
\hline 229 & Or. & Ad petendam pluviam. & 373 & Or. & Fer. VI p. Dom. IV Quadr. \\
\hline 230 & Or. & Dom. I p. Pent. & 375 & Or. & In Missis quotid. Defunct. \\
\hline 233 & Or. & $\begin{array}{l}\text { In Anniversario Defuncto- } \\
\text { rum." }\end{array}$ & 376 & Or. & $\begin{array}{l}n^{\circ} 2 . " \\
\text { Missa „Loquebar"." }\end{array}$ \\
\hline 234 & Postcom. & Missa pro infirmis. & 380 & Or. & Die Dedicationis Eccl. \\
\hline 235 & Sup. pop. & Fer. IV p. Dom. II Quadr. & 381 & Or. & Pro tentatis et tribulatis. \\
\hline 236 & Or. & Pro concordia. & 382 & Or. & De peste animalium. \\
\hline 239 & Or. & Pro Papa." & 383 & Secr. & Dom. VII p. Pent. \\
\hline 241 & Or. & Pro inimicis. & 385 & Or. & Sab. Sanct. Post prophe- \\
\hline 245 & Or. 3a & Sabb. Quat. Temp. Pent. & & & tiam I. \\
\hline 261 & Or. & 12 Martii." & 387 & Or. & 29 Sept. \\
\hline 264 & Or. & Fer. II infra Oct. Pent. & 392 & Or. & Com. Dedic. Eccl." \\
\hline 280 & Or. & 22 Febr.* & 395 & Or. & Misea pro vitanda mortali- \\
\hline 290 & Postcom. & 12 Mart. & & & tate. \\
\hline 292 & Or. & 28 Aug." & 397 & Secr. & Ad postulandam carjtatem. \\
\hline 297 & Or. & 25 Aprilis. & 398 & Or. & 11 Maji.* \\
\hline 298 & Or. & S. Matthiae. & 399 & Or. & 28 Jan.S. Agnetis secundo. * \\
\hline 312 & Or. & Pro devotis amicis. & 400 & Or. & 8 Aug. Ss. Mart." \\
\hline 313 & Or. & Dom. II in Quadr. & 401 & Or. & 23 Aprilis." \\
\hline 314 & Or. $1 \mathbf{a}$ & Sabb. Quat. Temp. Adv. & 402 & Or. & 29 Nov. S. Saturnino. \\
\hline 315 & Or. & Dom. in Sexagesima." & 403 & Or. & Missa „Sapientiam"." \\
\hline 317 & Or. & Pro tempore belli. & 404 & Or. & 14 Oct. \\
\hline 318 & Secr. & Missa pro pace." & 405 & Or. & 14 Sept. \\
\hline 319 & Or. & Fer. V p. Cineres. & 406 & Or. & Dom. IV p. Epiph. \\
\hline 320 & Or. & 25 Mart." & 407 & Or. & Pro Defunctis, n ${ }^{\circ} 11 . *$ \\
\hline 321 & Postcom. & Com. Dedicationis Eccl." & 408 & Or. & 28 Oct. Ss. Simonis et \\
\hline 323 & Or. & Dom. V p. Pent. & & & Judae." \\
\hline 324 & Or. & Ad postulandam caritatem. & 409 & Secr. & Dom. IV p. Pasch." \\
\hline 326 & Or. & Fer. V infra Oct. Pasch. & 410 & Or. & 24 Dec. \\
\hline 327 & Or. & Dom. I in Quadr. & 411 & Or. & Fer. IV infra Oct. Pasch. \\
\hline $339 b$ & is $\mathbf{1}$ Or. & Summorum Pontificum. & 412 & Or. & 2 Julii. Ss. Mart. * \\
\hline $\begin{array}{l}334 \\
336\end{array}$ & $\begin{array}{l}\text { Or. } \\
\text { Or. }\end{array}$ & $\begin{array}{l}\text { Fer. III infra Oct. Pasch. } \\
\text { Dom. III p. Pascha. }\end{array}$ & $\begin{array}{l}414 \\
418\end{array}$ & $\begin{array}{l}\text { Or. } \\
\text { Or. }\end{array}$ & $\begin{array}{l}\text { Pro remissione peccatorum. } \\
\text { Dom. X p. Pent. }\end{array}$ \\
\hline 338 & Or. 1 a & Fer. IV p. Dom. IV Quadr. & 432 & Or. & In Com. Omnium Ss, Sum- \\
\hline 339 & Or. & Dedicat. Altar. & & & morum Pontificum. \\
\hline 342 & Or. & Dom. IV p. Pascha. & 434 & Or. $\mathbf{2 a}$ & Pro Sponso et Sponsa. Dic- \\
\hline 346 & Or. & Sabb. Sancto. & & & to „Pater Noster”. \\
\hline 347 & Or. & $\begin{array}{l}\text { In Nativitate Dom. Ad pri- } \\
\text { mam missam. }\end{array}$ & $\begin{array}{l}436 \\
438\end{array}$ & $\begin{array}{l}\text { Or. } \\
\text { Or. 2a }\end{array}$ & $\begin{array}{l}\text { 24 Junii. } \\
\text { Fer. IV Maj. Hebd. }\end{array}$ \\
\hline 349 & $\mathrm{O}$ & Dom. Pent." & 439 & Secr. & Die Dedicationis Eccl. \\
\hline 350 & Or. & Dom. Resurrectionis. & 440 & Or. & 1 Jan." \\
\hline
\end{tabular}

1 This oration appears in the Veronense for the feast of Ss. Peter and Paul. Morn.merg, 332. 


No. Use in Occasion No. Use in Occasion
Missal
Missal

\begin{tabular}{|c|c|c|c|c|c|}
\hline 442 & Dr. & 30 Julii. Ss. Mart. & 539 & Or. & 2 Febr. Post distr. candel. \\
\hline 48 & r. & Fer. II infra Oct. Pasch. & 40 & Or. & 11 Aprilis.* \\
\hline & Postcom. & Sabb. p. Dom. IV Quadr. & 541 & Or. & In collatione sacrorum \\
\hline & Or. & $\begin{array}{l}\text { Ad postulandam hulilita- } \\
\text { tem. }\end{array}$ & 542 & Or. & $\begin{array}{l}\text { Ordinum. } \\
\text { Dom. II Adventus. }\end{array}$ \\
\hline 1 & r. & Pro navigantibus. & 45 & Or. & Dom. IV Adventus. \\
\hline & r. $6 \mathrm{a}$ & Sabb. Quat. Temp. Adv.* & 546 & Dr. & Dom. I Adv \\
\hline & Dr. & Missa de S. Cruce. & 547 & Or. & Fer. VI Quat. Temp. Adv. \\
\hline & Dr. & 30 Junii.* & 8 & Or. & Dom. XXIV p. Pent. \\
\hline & & $\begin{array}{l}14 \text { Aug. Vigil. Assumpt. } \\
\text { B. M. V. }\end{array}$ & 54 & $\begin{array}{l}\text { Postcom. } \\
\text { Secr. }\end{array}$ & $\begin{array}{l}\text { Fer. VI p. Dom. II Quadr. } \\
\text { Fer. IV Cinerum. }\end{array}$ \\
\hline & r. & Dom. XXII p. Pent * & 5 & & 9 Junii.* \\
\hline & ostcom. & issa tempore belli. & 6 & Pastcom. & 9 Sept. \\
\hline & ). & Aug. Pro S. Donato. & 57 & Or. & Dom. XXI \\
\hline & & Pro Defunctis, n 14." & & & Dom. V p. E \\
\hline 77 & r. & Dom. VI p. Pent. & 99 & r. & B Sept. In N \\
\hline & ז & $\begin{array}{l}\text { Fer. IV Quat. Temp. } \\
\text { Quadr. }\end{array}$ & 1 & & $\begin{array}{l}\text { B.M.V. } \\
\text { Fer. IV Quat. Temp. Adv. }\end{array}$ \\
\hline 59 & ecr. & Dom. III Adv. & 62 & O & Sabb. p. Dom. II \\
\hline 0 & $\mathbf{r}$. & p. Pent. & & Secr. & 9 Junii. \\
\hline 12 & 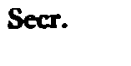 & postulandam continen- & 64 & $\begin{array}{l}\text { Postcom. } \\
\text { Sup. pop. }\end{array}$ & $\begin{array}{l}\text { Dom. in Septuagesima." } \\
\text { Sabb. Quat. Temp. Quadr. }\end{array}$ \\
\hline & & levotis amicis. & 87 & & Pro omnibus fidel. de- \\
\hline 84 & m. & postulandam continen- & $\begin{array}{l}570 \\
571\end{array}$ & $\begin{array}{l}\text { Or. } \\
\text { Secr. }\end{array}$ & $\begin{array}{l}1 \text { Aug. Pro Ss. Mart." } \\
28 \text { Oct.* }\end{array}$ \\
\hline 87 & ecr. & Fer. V p. Dom. Pass. & 72 & $\mathbf{r}$. & 9 Sept. \\
\hline 14 & ecr. & Oct." & 3 & & V p. D \\
\hline 15 & Sect. & 6 Jan. & 74 & & Pro petition \\
\hline 16 & Secr. & ebr. & 5 & & Martii.* \\
\hline 7 & Or. & tra persecutores Eccl. & 76 & Postcom. & Dom. XVIII \\
\hline 20 & Or. & 27 Dec. & $76 \mathrm{bi}$ & Or. & Com. Summ \\
\hline 21 & Or. & Dom. XV p. Pent. & & & \\
\hline 24 & Or. & Julii. & 77 & Po & Tempore fa \\
\hline$n=$ & r & I Quat. Temp. & 78 & Postcom. & $\begin{array}{l}\text { Pro Rege. } \\
\text { Fer. II p. Do }\end{array}$ \\
\hline 26 & D. & Fer. V p. Dom. Pass. & 1 & $\mathrm{Se}$ & Dom. III p. ] \\
\hline 27 & 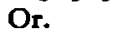 & Jan. Ss. Mart. & 3 & r. & Fer. VI p. Dom. II Quadr. \\
\hline 528 & r. & remis. peccat. & 35 & r. & Dom. I Pass." \\
\hline $3<0$ & Postcom. & 16 Sept. Ss. Mart. & & r. & Dom. XIX p. Per \\
\hline 530 & Secr. & 2 Febr. & 17 & n. & Pro inimicis. \\
\hline 53 & Postcom. & Fer. V infra Oct. Pasch. & & Postcom. & Fer. II p. Dom. II Quadr.* \\
\hline 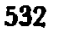 & Postcom. & Pro vitanda mortalitate. & 39 & & Dom. VI p. E \\
\hline & & 13 Dec.* & $\mathbf{0}$ & Postcom. & Pro Papa.* \\
\hline & Sup. & $\begin{array}{l}\text { Fer. VI Quat. Temp. } \\
\text { Quadr. }\end{array}$ & $\begin{array}{l}592 \\
594\end{array}$ & $\begin{array}{l}\text { Secr. } \\
\text { Secr. }\end{array}$ & $\begin{array}{l}\text { Missa de S. Cruce. } \\
\text { Ad postulandam gratiam }\end{array}$ \\
\hline & & Fer. III p. Dom.III Q & & & \\
\hline & & Pro Sponso et Sponsa. & & & Dom. I \\
\hline & astcom. & Pro remissione peccatoru & 600 & Secr. & acrimarum. \\
\hline
\end{tabular}

1 This oration also appears in the Veronense for the feast of Ss. Peter and Paul. Morrazro, 316. 


No. Use in Occasion No. Use in Occasion
Missal
Missal

\begin{tabular}{|c|c|c|c|c|c|}
\hline 602 & Secr. & $\begin{array}{l}\text { Ad repell. malas cogita- } \\
\text { tiones. }\end{array}$ & $\begin{array}{l}658 \\
659\end{array}$ & $\begin{array}{l}\text { Or. } \\
\text { Postcom. }\end{array}$ & $\begin{array}{l}18 \text { Aug. S. Agapit. Mart. } \\
22 \text { Febr.* }\end{array}$ \\
\hline 03 & Secr. & Pro Defunctis, $n^{\circ} 17$ & 660 & Or. & Dom. VIII p. Pent. \\
\hline 04 & Secr. & Dom. III p. Pasch. & 661 & Or. & Dom. XX p. Pent. \\
\hline & Secr. & Sabb. p. Dom. II Quadr." & 662 & Postcom. & Fer. IV Maj. Hebd." \\
\hline $0 \mathrm{t}$ & Secr. & Pro Defunctis, $\mathrm{n}^{\circ} 10$. & 664 & Secr. & 14 Aug. Pro S. Eusebio." \\
\hline 08 & Postcom. & Pro Defunctis, $n^{\circ} 6$. & 666 & Postcom. & Pro omni gradu Ecclesiae. \\
\hline & Secr. & Fer. IV p. Dom. IIQuadr.“ & 667 & Or. & Fer. V p. Dom. III Qu \\
\hline 16 & Secr. & 30 Aug. Ss. Mart. & 668 & Or. & 30 Aug. Ss. Mart. \\
\hline 17 & Secr. & Dom. I p. Pent." & 669 & Secr. & Dom. XVII p. Pent. \\
\hline & Secr. & Fer. VI infra Oct. Pasch. & 670 & Or. & 30 Nov. S. A \\
\hline & Secr. & Dom. XII p. Pent. & 671 & Secr. & 7 Oct. Pro Ss. Mart. \\
\hline & Secr. & Missis quotid. Defunct." & 677 & Postcom. & Dom. XV p. Pent. \\
\hline 21 & $\begin{array}{l}\text { Secr. } \\
\text { Secr. }\end{array}$ & $\begin{array}{l}\text { Fer. III p. Dom. I Pass. } \\
29 \text { Sept." }\end{array}$ & 678 & Sup. & $\begin{array}{l}\text { Fer. IV Quat. Temp. } \\
\text { Quadr. }\end{array}$ \\
\hline 24 & Secr. & Dom. V p. Epiph." & 679 & O & Fer. IV Quat. Temp. Pent. \\
\hline 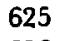 & Secr. & $13 \mathrm{Jan}$. & 680 & Postcom. & Fer. III infra Oct. Pent. \\
\hline & Secr. & 29 Jul. Ss. Mart. & 681 & Or & Sabb. Quat. Temp. Pent. \\
\hline & Secr. & $\begin{array}{l}24 \text { vel } 25 \text { Febr. S. Mat- } \\
\text { thiae.* }\end{array}$ & $\begin{array}{l}682 \\
683\end{array}$ & $\begin{array}{l}\text { Sup. por } \\
\text { Secr. }\end{array}$ & $\begin{array}{l}\text { Fer. III p. Dom. IV Quadr. } \\
\text { Pro devotis amicis. }\end{array}$ \\
\hline & & $\begin{array}{l}\text { Contra persecutores et male } \\
\text { agentes. }\end{array}$ & $\begin{array}{l}684 \\
684 b\end{array}$ & Or. la & Fer. IV Qu \\
\hline
\end{tabular}

630 Postcom. Fer. VIp.Dom.IIIQuadr."

631 Postcom. In Nativitate Dom. Ad secundam missam.

635 Or. 2a Sabb. Quat. Temp. Pent."

638 Postcom. Dom. XXI p. Pent.

639 Postcom. Dom. III Adventus.

641 Secr. 25 Martii."

642 Secr. Fer. V p. Dom. III Quadr.

643 Or. Fer. VI p. Cineres.

$644^{1}$ Or. $\quad$ Pro Defunctis, $n^{\circ}$ 5.

645 Sup. pop. Fer. IV Cinerum.

646 Or. 3a Sabb. Quat. Temp. Adv.

647 Or. Missa „Me expectaverunt"."

648 Or. Proquacumquenecessitate.

649 Or. 20 Januarii."

650 Secr. 6 Martii.*

651 Or. 21 Martii.*

653 Or. 18 Oct.

654 Postcom. Pro Defunctis, $n^{\circ} 10$.

655 Secr. Fer. $V$ in Coena Dom.

Postcom. Com. Summorum Pontificum."

686 Secr. Dom. XVI p. Pent.

687 Postcom. Alia ad poscenda suffr.

688 Secr. $11 \mathrm{Maji}$.

689 Secr. Pro rege.

691 Secr. Fer. VI p. Dom. IV Quadr.

692 Secr. 14 Aug. Vig. Assumpt.

B.M.V.

697 Secr. 22 Julii.

698 Secr. In Nativitate Dom. Ad se-

699 Secr. Ad postulandam patien-

$700^{\circ}$ Secr. tiam. 12 Julii. Ss. Mart.

701 Secr. 29 Aug.

702 Secr. Sabb. in Vig. Pent."

7034 Secr. In die tertio, septimo et trigesimo deposit. defuncti.

705 Secr. 18 Junii. Ss. Mart.

656 Or. Fer. VI p. Dom. III Quadr. 707 Secr. Missa „Sapientiam”.”

657 Secr. 14 Sept. 709 Pastcom. Dom. IV p. Epiph.

1 This oration appears in the Gel. Vetus in: Alia Missa in Coemeteriis. MoHLene, 1686.

Included because it is composed from two ancient prayers: In natale episcoponom in the Veronense-MoHLberg, 1002, and 997 respectively.

- This secret appears in the Veronense for the feast of Ss. Peter and Paul. Morregre, 281.

- This secret appears first in the Sacramentarium Fuldense saeculi $\boldsymbol{X}$, edited by G. Ruchrer and A. Schönfelder, Fulda 1912, 2488. 


No. Use in Occasion No: Use in Occasion
Missal
Missal

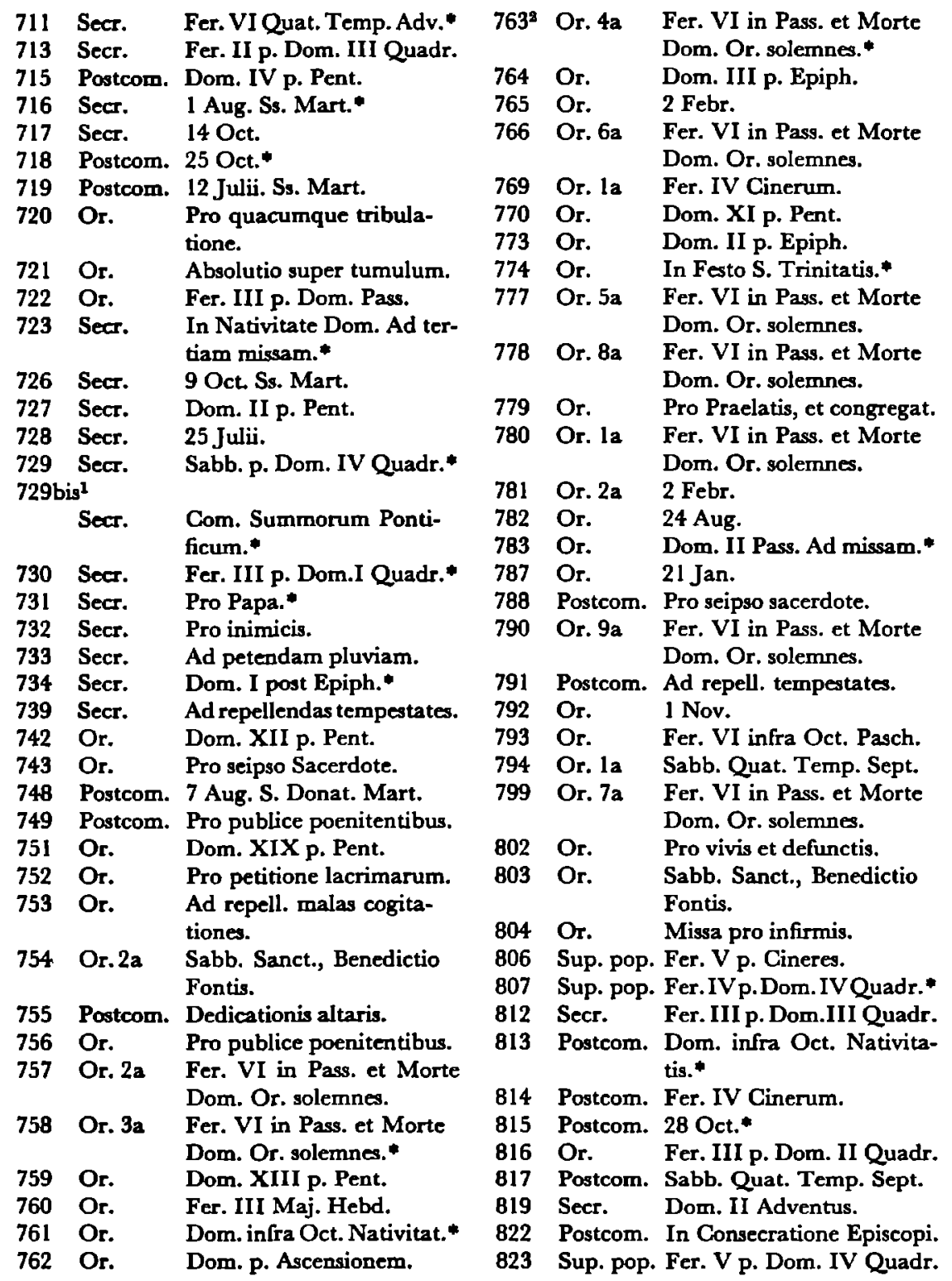

1 This secret appears in the Veronense: In natale episcoponon. MoHLBerg, 1013.

- This prayer for civil authorities, Oratio 4 a for Good Friday, has been changed to fit modern conditions and only the part has been of the ancient prayer: Omnipotens sempiteme Deus, in cujus manu sunt omnium potestates, et omnium jura regnorum: respice ad... Hence, we have included only so much of the prayer in this work. 


No. Use in Occasion No. $\begin{aligned} & \text { Use in } \\ & \text { Missal }\end{aligned}$ Occasion
Missal

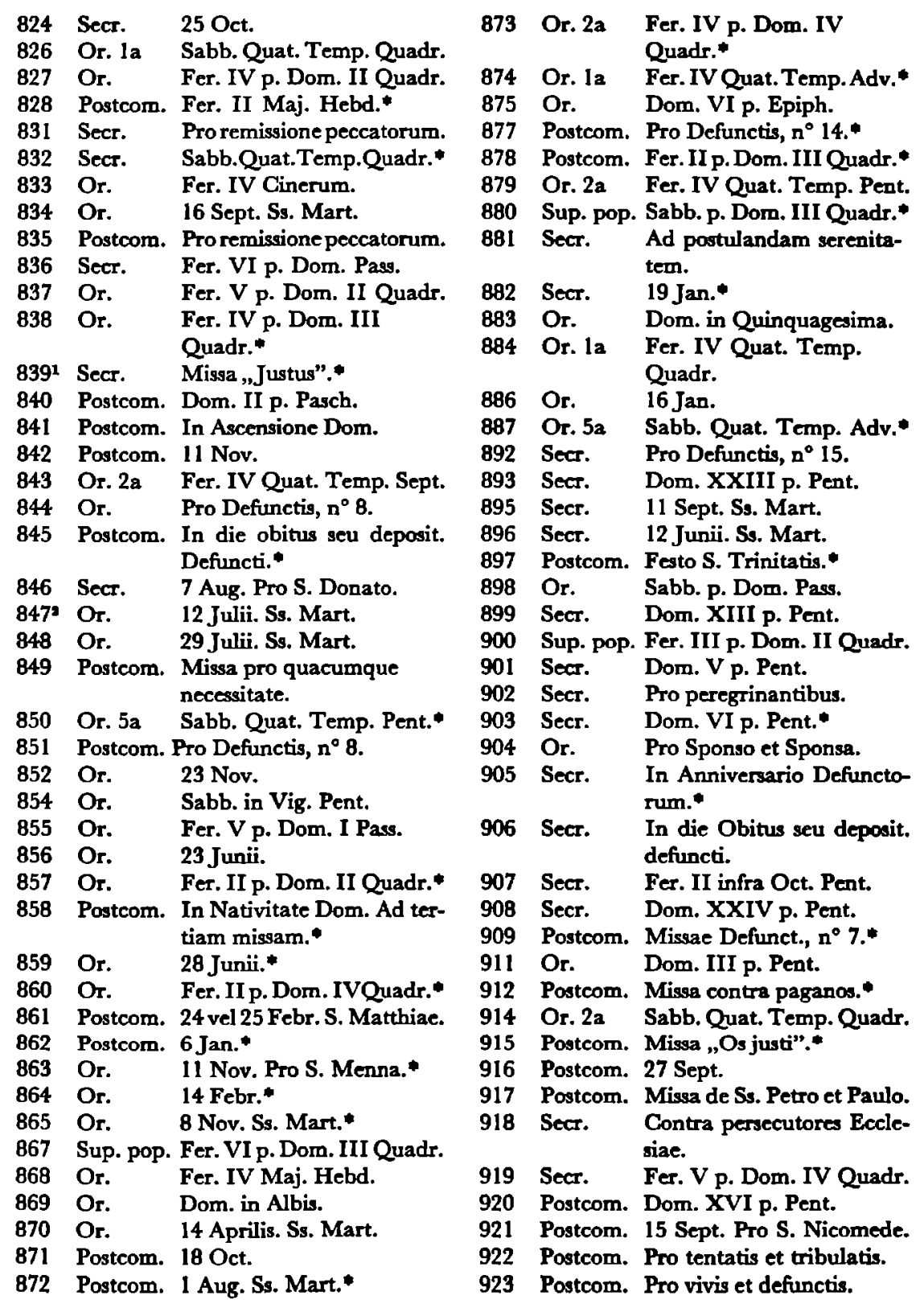

1 This secret appears in the Gel. Vetus for August 13. MoHLberg, 986.

- This oration appears in the Veronense for September 16. Mohzberg, 135. 


No. Use in Occasion No. Use in
Missal
Missal

924 Postcom. Dom. XIV p. Pent.

925 Secr. Fer. III infra Oct. Pent."

927 Postcom. Dom. X p. Pent.

928 Postcom. Sabb. Quat. Temp. Adv."

929 Or. Pro Defunctis, $n^{\circ} 10$.

930 Post com. 14 Jan. Pro S. Felice."

931 Or. In die tertio, septimo et trigesimo deposit. defuncti.

932 Postcom. 12 Maji.

934 Postcom. Ad postulandam serenitatem.

935 Or. Dom. I Pass.

936 Postcom. Pro Sponso et Sponsa.

938 Postcom. Fer.VI Quat. Temp. Sept.

939 Or. Pro Rege.

940 Postcom. Dom. V p. Epiph.*

941 Postcom. Com. Dedic. Eccl.

942 Postcom. Sabb. p. Dom. III Quadr.

943 Or. 26 Junii.

945 Postcom. Dom. in Quinquagesima."

947 Postcom. Dom. XXIII p. Pent."

948 Postcom. 14 Oct.

949 Postcom. 9 Junii. *

950 Or. Dom. III in Quadr.

952 Postcom. Fer. V p. Dom. Pass.

953 Postcom. 29 Junii. *

955 Postcom. Pro Praelatis.

957 Postcom. Dom. III p. Epiph.

958 Postcom. In collatione sacrorum Ordinum.

959 Postcom. Sabb. in Albis.

961 Postcom. 27 Dec.*

963 Postcom. 20 Jan.*

964 Postcom. Fer. $\mathrm{V}$ in Coena Dom. 965bis 1

Postcom. Summorum Pontificum.

969 Postcom. 30 Sept.

970 Postcom. Dom. II Adv.

971 Postcom. 28 Aug. Pro S. Hermete.

972 Postcom. Missa de Angelis.

973 Postcom. 15 Junii. Ss. Mart.

974 Postcom. Dom. p. Ascensionem."

975 Postcom. Dom. VI p. Pent.

976 Or. Fer. III p. Dom. I Quadr.

978 Secr. 13 Aug. Ss. Mart.

979 Secr. Dom. III p. Pent.

980 Secr. 23Julii.

981 Secr. Dom. XI p. Pent.

984 Secr. 22 Sept. Ss. Mart.
985 Postcom. Febr. VI infra Oct. Pasch.

986 Secr. Fer. VI p. Dom. III Quadr.

987 Sup. pop. Fer. IV Maj. Hebd.

989 Or. Fer. III p. Dom. IV Quadr.

991 Postcom. Fer. IV p. Dom. IV

Quadr.*

996 Postcom. Sabb. p. Dom. II Quadr.

997 Postcom. Fer. II p. Dom. I Pass.

999 Postcom. 7 Oct. Ss. Mart.

1000 Postcom. 13 Aug.

1002 Secr. Fer. IV infra Oct. Pasch.

1003 Secr. $\quad$ Fer. V p. Dom. I Quadr.*

1004 Secr. Fer. VI Quat. Temp. Pent.

1005 Secr. Dom. p. Ascensionem.

1008 Secr. Pro peste animalium.

1011 Secr. Sabb. Quat. Temp. Adv."

1012 Secr. Fer. VI p. Cineres.

1015 Secr. 30 Nov."

1016 Secr. Dom. I in Quadr.

1017 Secr. 28 Aug.

1019 Secr. Missa „Os justi”.*

1020 Postcom. Fer. III p. III Quadr.

1022 Postcom. 10 Aug.*

1026 Postcom. Fer. IV Quat. Temp. Adv.*

1027 Postcom. Dom. III p. Pent.

1031 Secr. Missa ,Sacerdotes tui"."

1032 Or. 29 Aug.

1033 Or. Dom. II p. Pent.

1034 Postcom. Dom. Pent."

1035 Postcom. Ad postulandam caritatem.

1036 Secr. Missa „Statuit”."

1039 Secr. In Festo S. Trinitatis.*

1040 Or. Fer. II p. Dom. Pass.

1041 Postcom. Pro navigantibus.

1043 Postcom. 25 Jan.*

1044 Secr. Fer. III p. Dom. II Quadr.

1045 Postcom. Sabb. Quat. Temp.

Quadr."

1046 Or. Fer. IV p. Dom. I Pass.

1048 Postcom. Fer. IV p. Dom. III Quadr.

1050 Postcom. 29 Nov. Pro S. Saturnino

1053 Or. 12 Junii. Ss. Mart.

1054 Or. 7 Oct. Ss. Mart.

1055 Secr. $12 \mathrm{Maji}$.

1056 Postcom. 19 Jan.*

1057 Secr. 28 Dec."

1058 Or. 28 Julii. Ss. Mart.

1059 Or. 9 Sept.

1060 Postcom. 22 Nov."

1 This postcommunion appears in the Veronense: In natali episcoporum. Morisero, 1026. 


No. Use in Occasion Ho. Use in Occasion
Missal
Missal

1061 Postcom. 12 Junii. Ss. Mart.

1062 Or. 12 Maji. Ss. Mart.

1063 Postcom. Dom. XI p. Pent.

1064 Secr. 15 Junii.

1065 Postcom. Dom. VIII p. Pent. *

1066 Postcom. Fer. V p. Dom. III Quadr.

1069 Postcom. Fer. VI p. Cineres."

1070 Sup. pop. Fer. V p. Dom. III Quadr.

1073 Secr. Pro vitanda mortalitate.

1074 Postcom. 24 Junii.

1075 Postcom. Fer. IV Quat. Temp. Pent.*

1076 Postcom. Fer. IV Quat. Temp. Sept.

1078 Postcom. 28 Jan."

1079 Postcom. 30 Nov.*

1082 Postcom. 11 Aug. Ss. Mart.*

1083 Postcom. Fer. VI Quat. Temp. Pent."

1086 Postcom. Fer. VI p. Dom. Pass.

1087 Postcom. Fer. IV p. Dom. II Quadr.*

1089 Postcom. Sancta Maria in Sabb.

1090 Postcom. Dom. IV Adv.*

1091 Postcom. Pro congregatione et familia.

1093 Postcom. 22 Juli.

1095 Secr. 28 Jan.*

1096 Secr. 21 Sept.

1097 Postcom. Pro Defunctis, $n^{\circ} 17$.

1099 Secr. Fer. IV p. Dom. IV Quadr.

1100 Postcom. 23 Nov. Pro S. Felicitate.

1103 Postcom. Dom. I p. Epiph."

1106 Secr. Fer. III infra Oct. Pasch. *

1107 Secr. 26 Dec.

1108 Secr. 15 Sept. Pro S. Nicomede.

1109 Secr. 27 Dec."

1110 Secr. In Ascensione Dom.*

1111 Secr. In consecratione Episcopi.

1116 Secr. 2Julii. Ss. Mart.

1117 Postcom. In die tertio, septimo et trigesimo deposit. Defuncti.

1118 Secr. Dom. XXI p. Pent.*

1119 Secr. Pro Defunctis, $n^{\circ} 8$.

1120 Secr. $\quad$ Pro defunctis, $n^{\circ} 7 . *$

1121 Secr. Sabb. p. Cineres.

1123 Secr. Dom. in Albis.

1125 Secr. Fer. VI Quat. Temp.

Quadr.

1126 Secr. Fer. V infra Oct. Pasch.

1127 Secr. Dom. VIII p. Pent.

1128 Secr. Fer. IV Maj. Hebd.
1130 Secr. Fer.IV p.Dom.III Quadr.*

1131 Secr. Sabb. Sancto.*

1132 Secr. Pro Sponso et Sponsa.

1133 Sect. Pro congregatione et familia.

1134 Secr. Pro Defunctis, $n^{\circ} 11 . *$

1135 Postcom. Dom. I Adv.

1136 Postcom. Dom. I p. Pent.

1137 Secr. Dom. X p. Pent.

1138 Postcom. 25 Aprilis.

1140 Postcom. Dom. V p. Pasch."

1142 Or. Pro quacumque tribulatione.

1143 Secr. 24Junii.

1144 Secr. Sancta Maria in Sabb.

1146 Postcom. Dom. VII p. Pent.*

1147 Sup. pop. Fer. III p. Dom. III Quadr.

1148 Secr. Dom. XV p. Pent.*

1149 Sup. pop. Fer. III Maj. Hebd.

1150 Or. Dom. XVI p. Pent.

1151 Postcom. Sabb. p. Dom. IV Quadr.

1152 Postcom. 23 Julii.*

1154 Sup. pop. Sabb. p. Dom. Pass.

1155 Sup. pop. Fer. VI p. Cineres.

1157 Or. 3a Sabb. Quat. Temp. Sept.

1158 Postcom. Fer. IV Quat. Temp. Quadr.*

1159 Postcom. Dom. IX p. Pent.

1160 Postcom. Fer. VI Quat. Temp. Adv. *

1161 Secr. In Collatione sacrorum Ordinum.

1164 Postcom. Fer. V p. Dom. I Quadr.

1167 Secr. 8 Sept.*

1168 Or. Ad postulandam continentiam.

1169 Secr. Sabb. Quat. Temp. Pent.

1171 Or. 5a Sabb. Quat. Temp. Sept.

1172 Postcom. 28 Aug."

1173 Postcom. 11 Sept. Ss. Mart.

1175 Postcom. Fer. III p. Dom. II Quadr.*

1178 Postcom. Dom. XII p. Pent.

1179 Postcom. In Litaniis maj. et minor.

1180 Secr. 23 Nov. Pro S. Felicitate.

1181 Or. $\quad$ Dom. I p. Epiph.

1182 Postcom. 28 Dec.

$1183^{1}$ Or. Fer. VI In Pass. et Morte Dom.

$1184^{2}$ Postcom. Pro res publicas moderantibus.

1 This prayer does not stand in BruYuarrs, II, since it has been reinstated since the publication of Les oraisons. We have arbitrarily given it a number in order to facilitate reference to it. To this prayer we have also given a number. 


\title{
INDEX OF GREEK WORDS
}

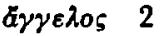

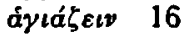 \\ aĩuv 54, 55

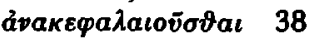

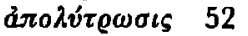

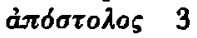 \\ dexiegev́s 140 \\ dıakovía 104 \\ Stákovos 104 \\ ธเкสเоขับ 12

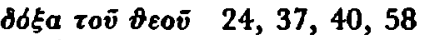 \\ $\delta \circ \xi a ́ \zeta \varepsilon \iota \nu \quad 41$

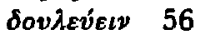

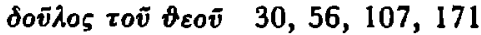

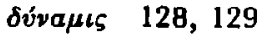 \\ zov 32 \\ Elgर्भin 47

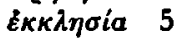

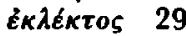

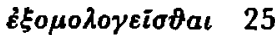

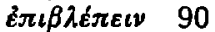

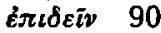

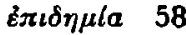

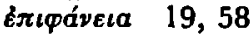 \\ Ẽoya ảyatá 44

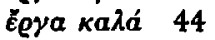

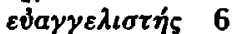 \\ $\zeta \omega \eta \dot{\eta} 43$ \\ $\theta \lambda l \varphi$ is 62 \\ Ovoía 18, 75 \\ i $\alpha$ vs 129 \\ кaıtós 43 \\ кท́еvуна 52

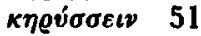

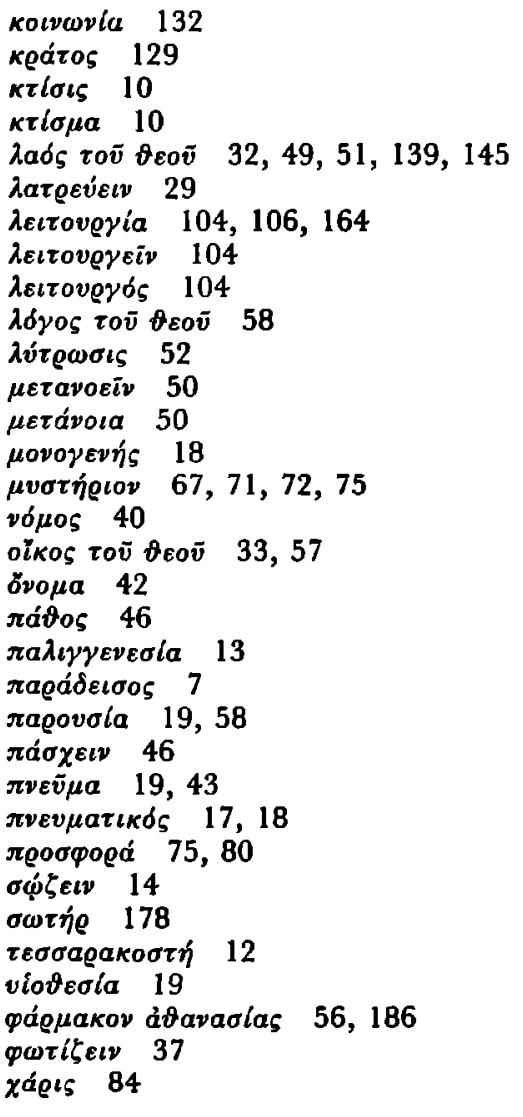





\section{INDEX OF LATIN WORDS}

\begin{tabular}{|c|c|c|}
\hline $\begin{array}{l}\text { abbas } 2 \\
\text { absolutio } 156 \\
\text { abstinentia } 180 \\
\text { abstinere } 10,179 \mathrm{f} ., 181 \\
\text { acceptus } 87,135 \\
\text { accipere } 86 \mathrm{f} ., 200 \\
\text { actio } 48,91 \mathrm{ff} ., 137,200 \\
\text { adesse } 198 \\
\text { adjutor } 160 \\
\text { adjuvare } 192 \\
\text { adoptio } 19 \\
\text { adscriptus } 152 \\
\text { adunare } 19 \\
\text { aegypticus } 66 \\
\text { aeternitas } 183,186 \\
\text { aetemus } 21 \mathrm{f} . \\
\text { agere } 91 \mathrm{ff} ., 109,112,20 \\
\text { alimentum } 10,179 \\
\text { altare } 19 \mathrm{f} . \\
\text { amator } 160 \\
\text { amplificare } 15 \\
\text { angelicus } 2,63 \\
\text { angelus } 2,104 \\
\text { annuere } 135 \mathrm{f} . \\
\text { annuus } 96,113,198 \\
\text { antistes } 20 \mathrm{f} . \\
\text { apostolious } 2,64 \\
\text { apostolus } 2 \\
\text { apparere } 22 \\
\text { apparitio } 22 \\
\text { aptare } 147 \\
\text { archangelus } 3\end{array}$ & 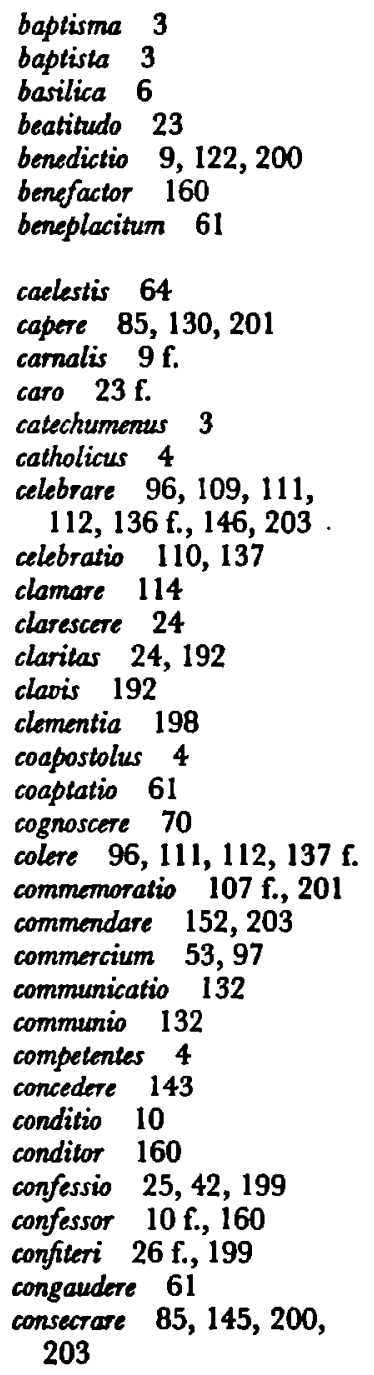 & $\begin{array}{l}\text { dedicare } 138 \\
\text { dedicatio } 138 \\
\text { deferre } 75,81,83,108 \text {, } \\
113,163 \\
\text { deposcere } 119 \\
\text { deprecari } 114 \mathrm{f} ., 149,150 \text {, } \\
201 \\
\text { deprecatio } 115 \\
\text { descendere } 90 \\
\text { devotio } 97 \mathrm{ff}, 179,200 \\
\text { deootus } 28 \\
\text { dextera } 181,195 \\
\text { diabolicus } 4,64 \\
\text { diabolus } 4 \\
\text { dicare } 83,138 \mathrm{f} ., 146 \mathrm{f} ., \\
203 \quad 199 \\
\text { dignari } 199 \\
\text { dispositor } 160 \\
\text { divinus } 64 \\
\text { doctor (gentium) 28, } 160 \\
\text { dominator } 160 \\
\text { dominicus } 65 \\
\text { domus } 57 \\
\text { donum } 83 \mathrm{ff} . \\
\text { dormire } 28 \\
\text { dormitio } 136\end{array}$ \\
\hline
\end{tabular}


ecclesiasticus 65

effectus $122 \mathrm{f}, 124,189$, 201

efficere $124 \mathrm{f}$.

clectus 29,40

episcopus 6

evangelicus 6,65

evangelista 6

exaudire 141

exhibere $100,153 \mathrm{f}$.

exorare $118 \mathrm{f} ., 149,150$, 201

expedire 154,180

expeditus 174

expetere 119

expugnare 180

expurgare 180

exsequi 100,200

exsistere 154

exsolvere 101

facies 194

familia 29, 154, 191

famulari $29 \mathrm{f}$.

famulus $30,192,199$

femineus 434

festa $108 \mathrm{f}, 201$

festioilas 108, 109 f., 136, 201

fidelis $30 \mathrm{f}$.

fideliter 31

fides $31 \mathrm{f}$.

fiducialiter 61

firmamentum 174

firmare 94

flagitare 115

fraternus 65

frequentare 102

frequentatio 102

gentes 32

gerere $102,109,200$

gloria 23, 32 ff., 192, 200

glorificatio 11

gloriosus $34 \mathrm{f}$.

gradi 196

gratianum actio 93, 116

gratias agere $92 \mathrm{f}$, 116

- exhibere 92

- referre 92

habitaculum 57

haereticus 6,66

honor 110 hostia 75 f., 82, 88, 193, 200, 202

hostis 4

humilis 35

humilitas $35 \mathrm{f}, 198$

humiliter 36,150

illuminare $36 \mathrm{f}$.

illustrare 37

illustratio 37

immolare 81, 85, 139, 146, $193,200,203$

immolatio 139

implorare 116

impugnare 174

impugnator 160

incarnari 11

incarnatio 12

incessabilis 62

incessanter 62

indesinenter 62

indulgentia $155 \mathrm{f}$.

indulgere 157, 203

infirmitas 181

inhabitatio 12

inimicus 4,38

instaurase 38

institutor 160

intendere $88 \mathrm{f}, 200$

intercedere $116,157 \mathrm{ff}$., I61, 198, 203

intercessio $116,159 \mathrm{f}$, 188, 203

intercessor 160

intervenire $116,160 \mathrm{f}$.

interoentio 116,161

interventor 160, 161

invisibiliter 62

invocare 116

invocatio $116 \mathrm{f}$.

israeliticus 6,66

jejunare $181 \mathrm{f}$.

jejunium 39, $182 \mathrm{f}$.

justificare 12, 15

justitia 39

justus $39 \mathrm{f}$.

laetificare $15,99,114,199$

languor 183

largitor 160

laus 78, 193

lavacrum 3

lex 40 libamen 140

libare 140

libatio 73,140

liber 152

locus 57

lux 23

magnificare 15,41

magnifucus 52

majestas 40, 192, 198

martyr 6, 199

martyrium 7

medela $127,183 \mathrm{f.}, 186$, 203

mederi 184

medicatio 184

medicina 126,184

medicinalis $184 \mathrm{f}$.

mereti 199

meritum $161 \mathrm{ff}$.

miles 173

militia 173,175

minister 104

ministerium $104 \mathrm{f}$.

ministrare 104

miserator 160

mortificare 12,15

mundare 176

mundus (n) $41 \mathrm{f}$.

munimen 175

munire $163,175 \mathrm{f}, 203$

munus $80,82,88,163 \mathrm{ff}$., 193,202

mysterium 65, 67 ff., 200, 202

natalis 111

natalitia $110 \mathrm{f} ., 136,138$

nativitas 111,136

nexus 168,203

nomen 25,42 f., 192

novitas 43

noves 43

oblatio $80 \mathrm{f} ., 200,202$

oblata $82 \mathrm{f}$.

obsecrare 117

obsequium 102, $105 \mathrm{f}$.

observantia 111

observatio 111, 200

offerre 75, $81 \mathrm{f} ., 146$, 163,193

offrium 95, 106, 137, 200

operari 68,124 f., 201 


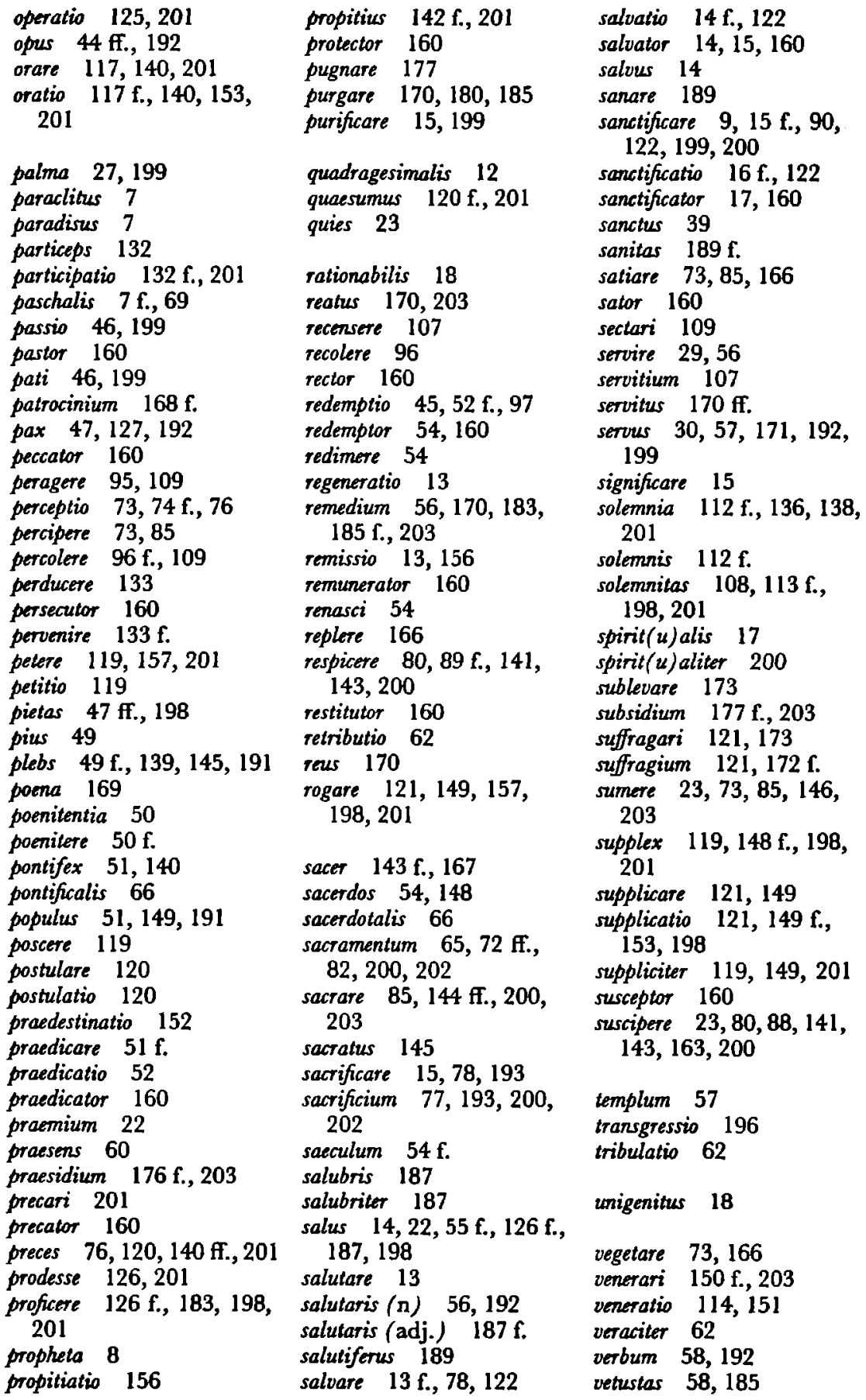


vetustus 58

vexillum 178

via $196 \mathrm{f}$.

victoria 27,199

virilis 66 virtus $127 \mathrm{ff}, \mathrm{g} 201$

visibiliter 62

visilatio 58

vila $22,59 \mathrm{f}$.

vitiosus 190 vitium $182,185,190$

vivificare 15,60

votum 121

vultus 194 




\section{THESES}

I

The cultic sense of actio in liturgical Latin has in recent years been over emphasized. This has led to faulty interpretation of some liturgical texts.

II

The secret for Dom. III Quadr. should read: Haec hostia... emundet nostra delicta: et sacrificium celebrandum subditorum tibi corpora mentesque sanctificet - not ad sacrificium celebrandum.

\section{III}

The statement of Louis Brou (Les oraisons des dimanches après la Pentecôte. Commentaire liturgique, Bruges 1959, p. 22), "nous dirions maintenant: soient toujours reçus en état de grâce" to explain the meaning of sanctificatione in the text of the secret for the third Sunday after Pentecost: Respice, Domine, munera supplicantis Ecclesiae: et saluti credentium perpetua sanctificatione sumenda concede, is not accurate.

\section{IV}

The word pastor was used in Early Christian Latin for priests and bishops without strict distinction. It has never become a technical term, but has remained one which expresses the duty or function of the respective person.

The term porta clausa as it is applied to Mary in Latin hymnology does not convey the full import of the Biblical figure as it appears in Ez. 44, 1-3.

\section{VI}

The legalistic and political elements in pagan Roman prayer are sometimes misinterpreted (e.g., Franz Cumont, Les religions orientales dans le 

paganisme romain ${ }^{3}$, Paris 1929, p.44; G. Appel, De Romanorum precationibus, Giesen 1909, p. 145).

\section{VII}

The suggested emendation of Clemens Romanus, Ad Cor., 60, 4, by the insertion of $\omega \sigma \tau \varepsilon \sigma \dot{\omega} \zeta \varepsilon \sigma \vartheta a \iota l \hat{\eta} \mu \bar{\alpha} \zeta$ is not necessary (cf. J. B. Lightfoot, The Apostolic Fathers, Part I, S. Clement of Rome, London 1890, I, p. 145 f.; II, p. 178.).

\section{VIII}

The disposition of the key words in the opening sentences of the antesanctus passages in the so-called Visigothic and Gallican sources gives evidence that also in those milieus there existed the tradition that gratias agere had a wider content than the expression "to give thanks" in modern languages has.

IX

The statement of Fr. Gokey (The Terminology for the Devil and Evil Spirits in the Apostolic Fathers, Patristic Studies 93, Washington, D.C. 1961, p. 177) that in the Martyrium Polycarpi "the epithets a

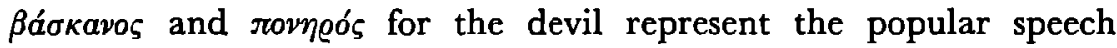

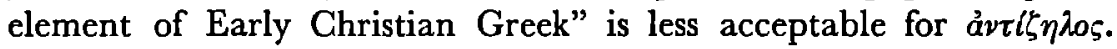

$\mathrm{X}$

The translation of a qui-clause, modifying the address in an oration by an independent sentence (cf. Missel Biblique, Bourges 1961) destroys the traditional structure of Christian euchology.

\section{XI}

The inclusion of Christian authors in the curriculum can be a powerful contributing factor to the awakening of a greater interest in the study of Latin in Catholic high schools in the United States. 
Stellingen by Mary Pierre Eliegracht,

Remarks on the Vocabulary of the Ancient Orations in the Missale Romanum, 

